\title{
INFLUENCE OF COVER CROP AND TILLAGE MANAGEMENT PRACTICES ON SOIL PHYSICAL AND HYDRAULIC PROPERTIES
}

\author{
A dissertation \\ Presented to \\ The Faculty of the Graduate School \\ University of Missouri-Columbia
}

In Partial Fulfilment

Of the Requirements for the Degree

Doctor of Philosophy

by

SAMUEL IDOKO HARUNA

Dr. Stephen H. Anderson

Dissertation supervisor

MAY, 2017 
(C) Copyright by Samuel Idoko Haruna, 2017

All Rights Reserved 
The undersigned, appointed by the Dean of the Graduate School, have examined the dissertation entitled,

\section{INFLUENCE OF COVER CROP AND TILLAGE MANAGEMENT PRACTICES ON SOIL PHYSICAL AND HYDRAULIC PROPERTIES}

Presented by

SAMUEL IDOKO HARUNA

a candidate for the degree of

\section{DOCTOR OF PHILOSOPHY}

and hereby certify that, in their opinion, it is worthy of acceptance.

Dr. Stephen H. Anderson, Professor (Chair)

Dr. Nsalambi V. Nkongolo, Adjunct Professor

Dr. Ranjith P. Udawatta, Associate Professor

Dr. Frieda Eivazi, Adjunct Associate Professor

Dr. Allen L. Thompson, Professor 
Unto the king eternal, immortal, invisible, the only wise God, be honor and glory forever and ever. Amen. (1 Timothy 1:17) 


\section{ACKNOWLEDGEMENTS}

Obtaining the doctoral degree requires hard work, and dedication. It requires laser focus concentration on studies, and especially, research. It can be overwhelming and it certainly is not for the faint of heart. So many times you question your decision to pursue a doctoral degree. However, with support and guidance, this journey can be made easier. This section serves to appreciate the efforts of those who have helped me through this journey.

Words are not enough to express my sincere appreciation to my advisor and mentor, Dr. Stephen Anderson, for his support and guidance. I appreciate the encouragement, but more importantly, the constructive criticism and corrections. You thought me a lot; academically and professionally. Thanks for the 'push'. Thanks for teaching me to not be afraid to make speculations but to be careful to separate speculations from facts. Special thanks also goes to Mrs. Anderson for having me over during Thanksgiving celebrations. As an international student, spending Thanksgiving at your home made me feel warm. Also, thanks for the cookies with 'redoximorphic features'. It was a refreshing way to think about soil science.

Profound appreciation also goes to Dr. Nsalambi Nkongolo. Thanks for the assistantship through my masters and doctoral program. Thanks for your openness and readiness to teach. You are a mentor who thought me many things. You never once looked down my ideas, no matter how foolish. Thanks for having me over to your home during Thanksgiving, graduation and some African celebrations. Indeed, over these years, I have 
become your son. Even though you said I should not call you 'boss', you'll always be my BOSS. I owe you a lot.

Special thanks also goes to committee members Dr. Allen Thompson, Dr. Frieda Eivazi, and Dr. Ranjith Udawatta. You always welcomed me into your offices and gave me valuable information. Thanks for the constructive criticisms and suggestions. I will never forget your contributions. Appreciation is also extended to Dr. Clark Gantzer for always having an open door. Thanks for reminding me that "you cannot solve all the problems out there, but you can make little contributions daily that may cumulatively help solve some of the problems". You are appreciated. I also acknowledge all professors in Soil, Environmental and Atmospheric Sciences Department. I learnt a lot from you during my academic sojourn.

This dissertation would not be complete without the fellowship provided by Middle Tennessee State University, Murfreesboro, through the Underrepresented Minority Dissertation Fellowship for the 2016/2017 academic session. The fellowship provided an opportunity to gain valuable teaching experience while writing this dissertation. This unique opportunity is greatly appreciated. I also appreciate the support received from the provost's office, and the Agribusiness and Agriscience department throughout this fellowship.

Exalted appreciation is extended to my parents, Mr. Stephen Haruna and Mrs. Grace Haruna. You were my first teachers and you cultivated in me the love for teaching. Thanks for letting me pursue my dreams. Even though I was gone for several years, you kept praying for, supporting, and motivating me. I could not have asked for better parents. You are my greatest mentors. This one is for you. I also deeply appreciate my siblings; 
Mrs. Rosemary Daniels, Mrs. Deborah Idachaba, Mrs. Hannah Akuh, Mr. Raymond Haruna, and Mrs. Charity Odiba. Thanks for your love, care and support. I could not have done this without you. I love you dearly.

I appreciate the friendship of Syaharudin Zaibon, Janith Chandrasoma, Sitterine Thongpussawal, Gurpreet Kaur, Alexander Taylor, Patricia Quakenbush, Heraclite Bikumbu, Diana Pallangyo, Ali Al-Surraji, Amanda Wolfgeher, Sebohattin Ackigoz, Handan Sahin, Eda Akdemir, Evren Cetin, and Saranya Norkaew. You made the stressful journey lighter. Special appreciation goes to my sweetheart, Gloria Abuka, for being there for me all these years. I love you.

Finally, my greatest appreciation goes to God; my source of strength and inspiration. I am nothing without You.

Place: Columbia, MO

Date: May, 2017

(Samuel Haruna) 


\section{TABLE OF CONTENTS}

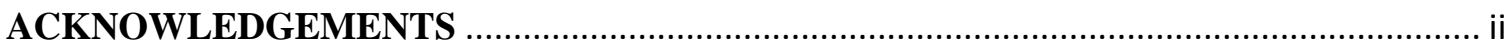

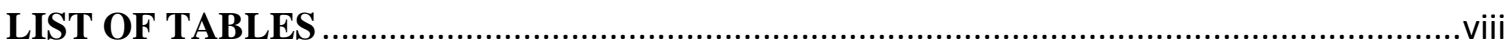

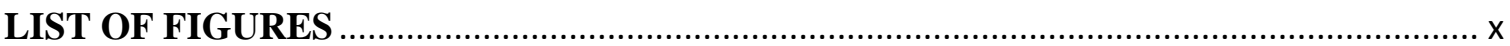

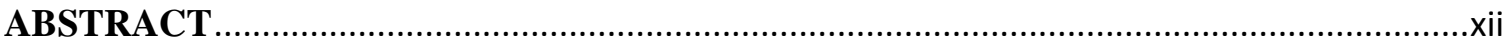

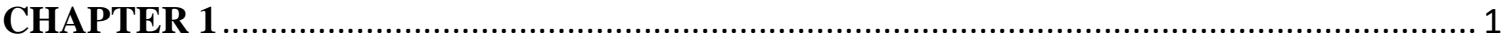

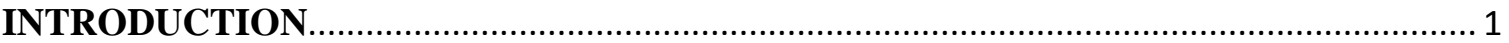

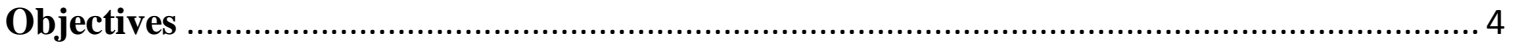

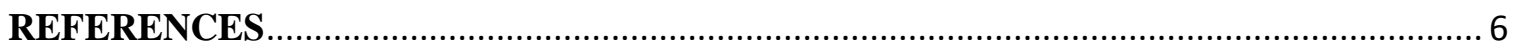

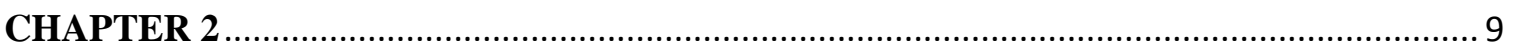

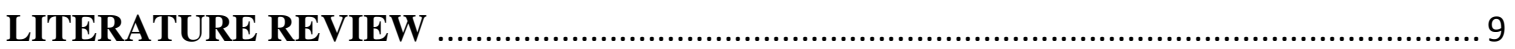

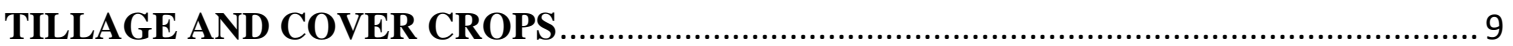

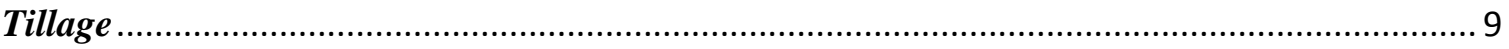

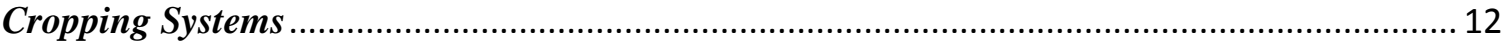

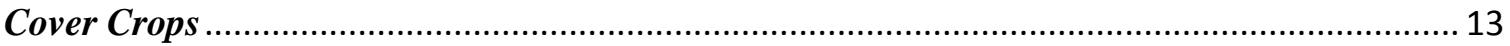

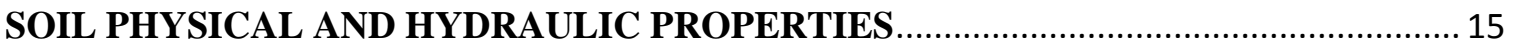

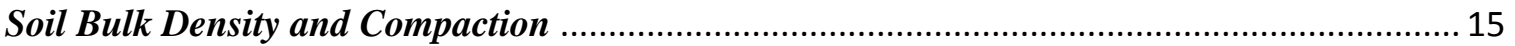

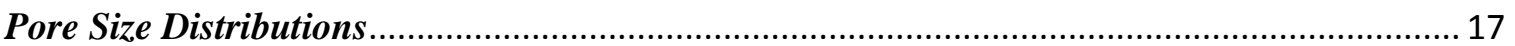

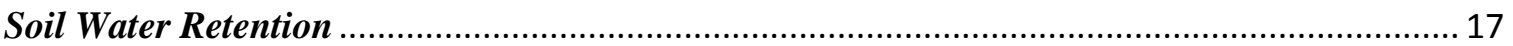

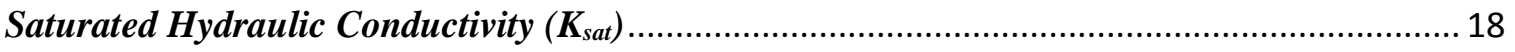

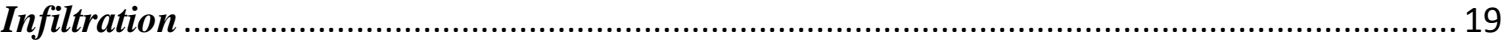

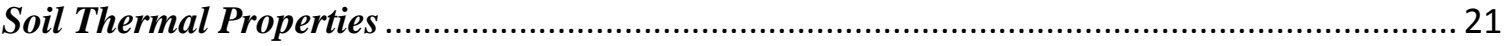

TILLAGE EFFECTS ON SOIL PHYSICAL AND HYDRAULIC PROPERTIES.............. 22

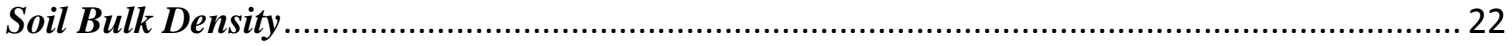

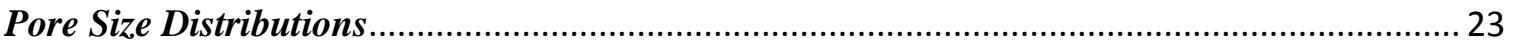

Soil Water Retention and Saturated Hydraulic Conductivity ................................................. 24

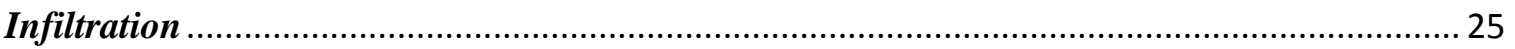

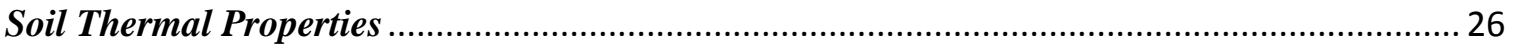

COVER CROP EFFECTS ON SOIL PHYSICAL AND HYDRAULIC PROPERTIES ..... 26

Soil Bulk Density and Pore Size Distributions........................................................................ 26

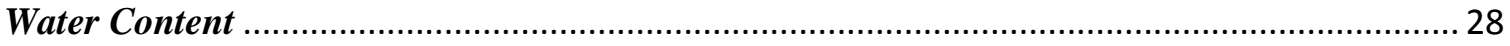

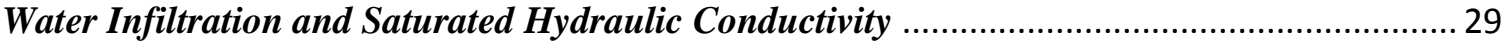




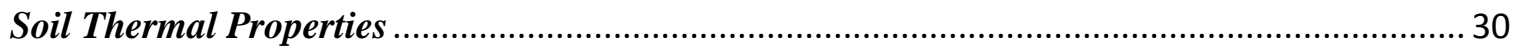

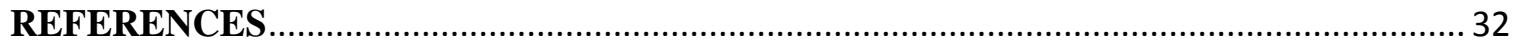

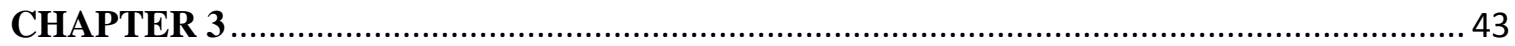

SOIL HYDRAULIC PROPERTIES: INFLUENCE OF TILLAGE AND COVER

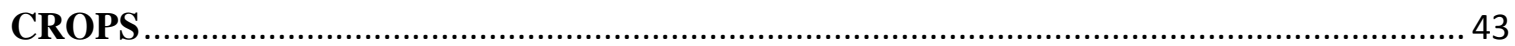

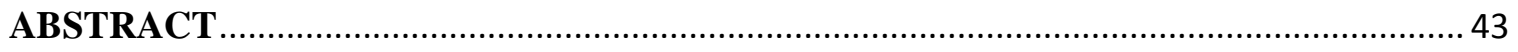

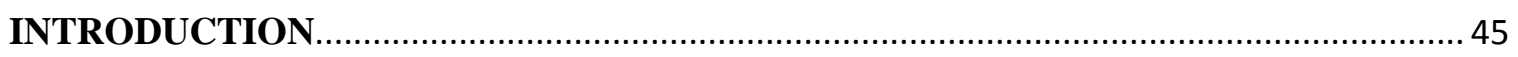

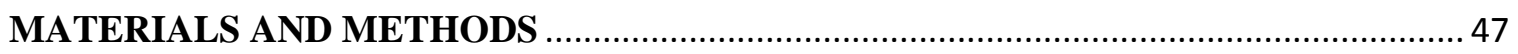

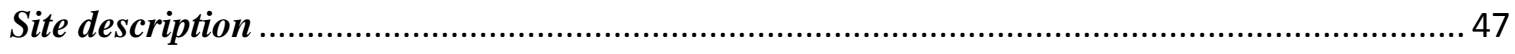

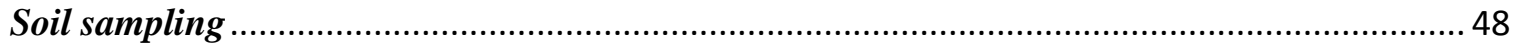

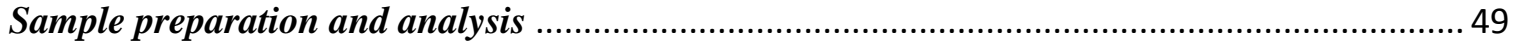

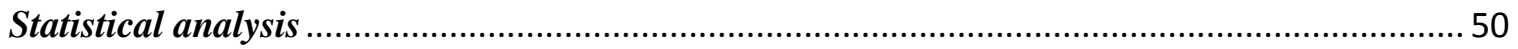

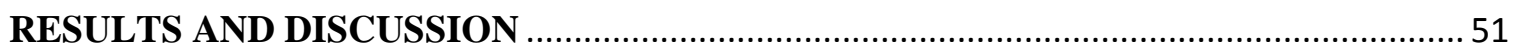

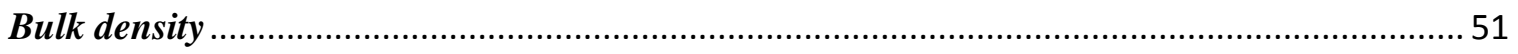

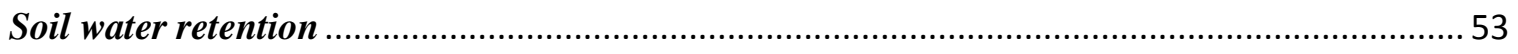

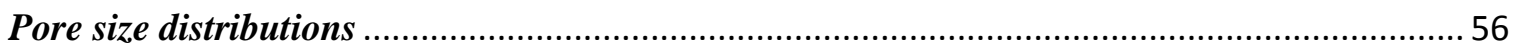

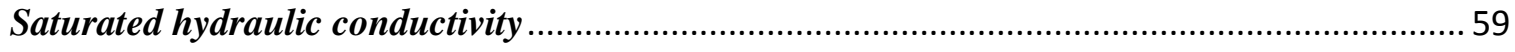

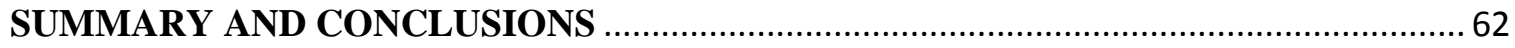

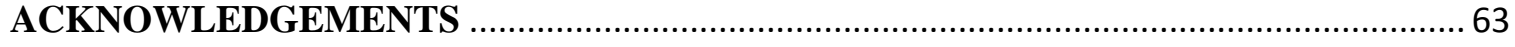

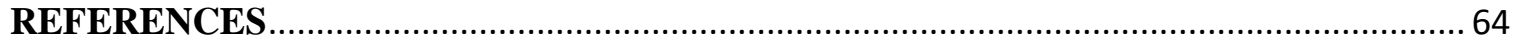

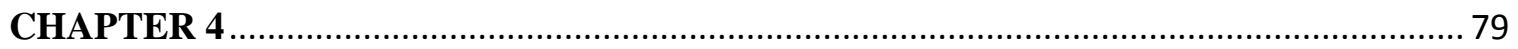

IN SITU INFILTRATION AS AFFECTED BY COVER CROP AND TILLAGE

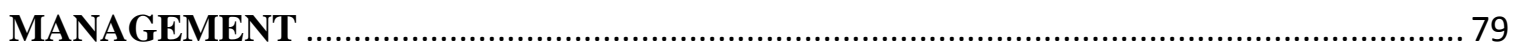

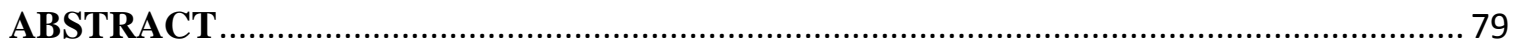

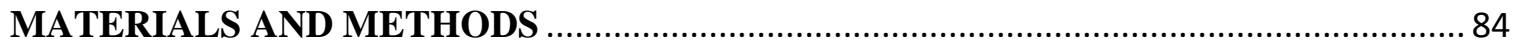

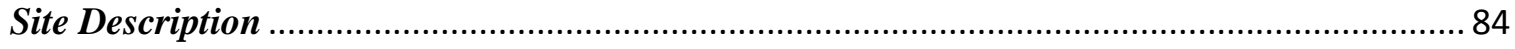

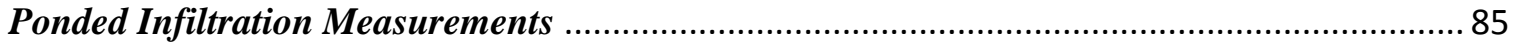

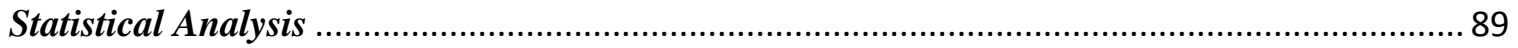

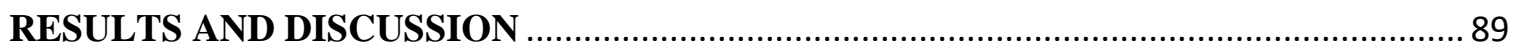

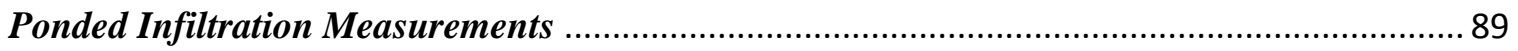

Bulk density $(\mathrm{Db})$ and antecedent volumetric water content $(\mathrm{VWC})$..................................... 90

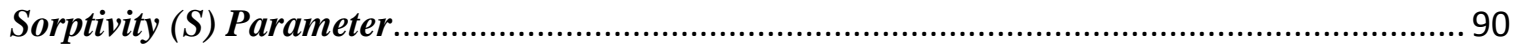

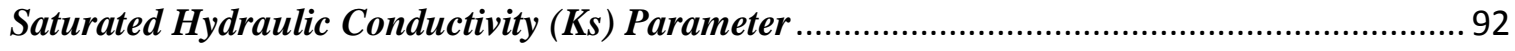

Field Saturated Hydraulic Conductivity (Kfs) Parameter. ....................................................... 94 


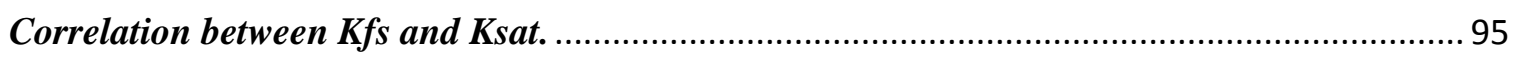

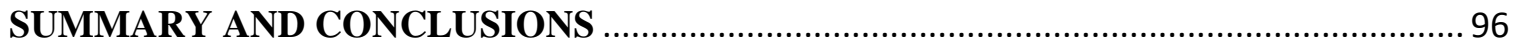

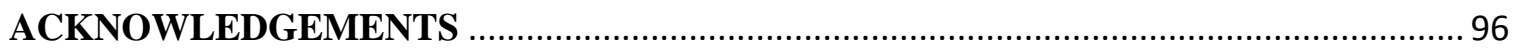

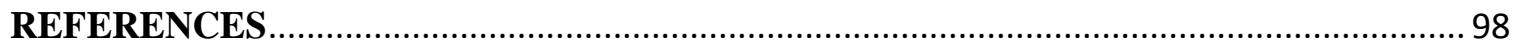

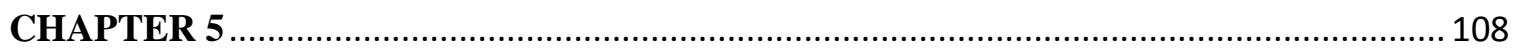

SOIL THRMAL PROPERTIES INFLUENCED BY PERENNIAL BIOFUEL AND

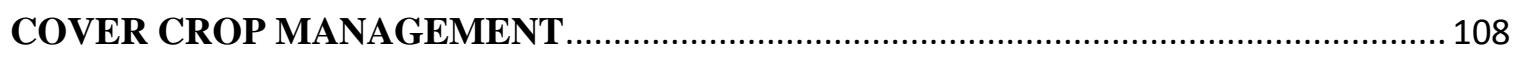

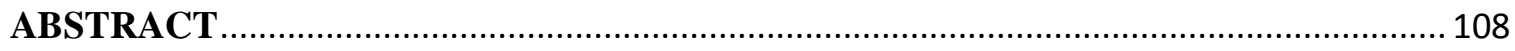

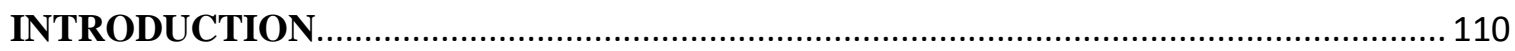

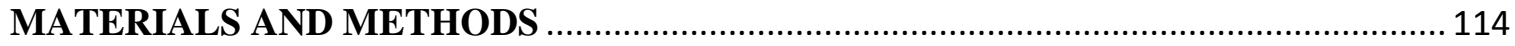

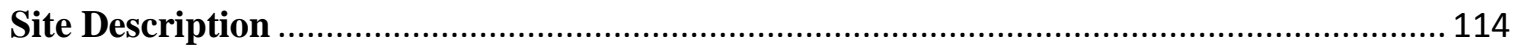

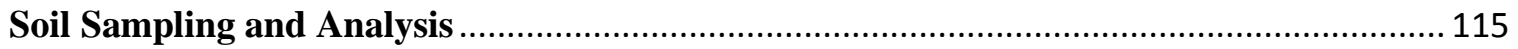

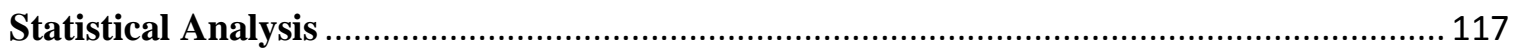

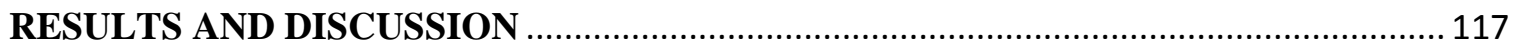

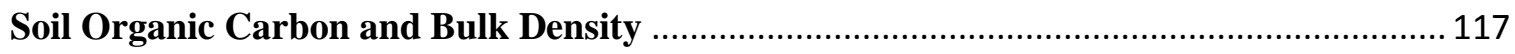

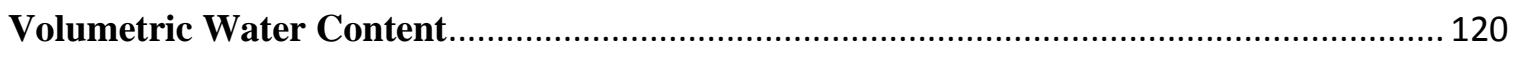

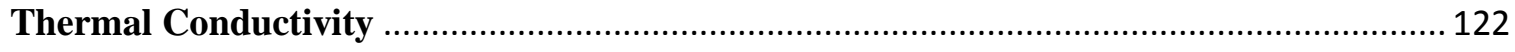

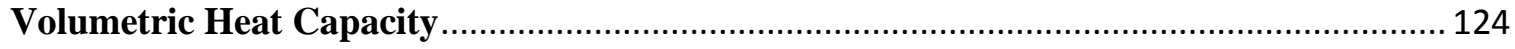

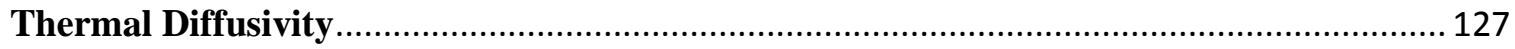

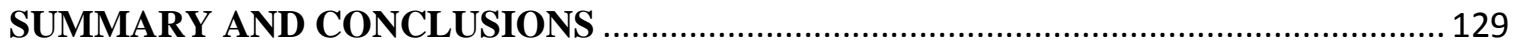

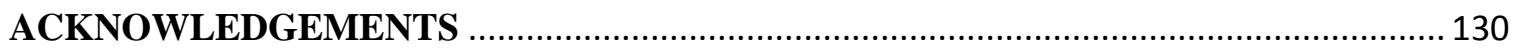

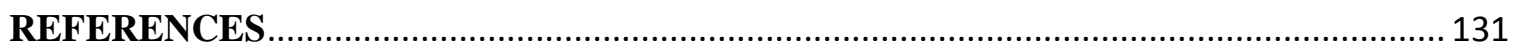

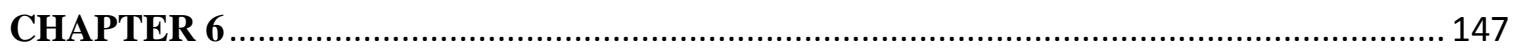

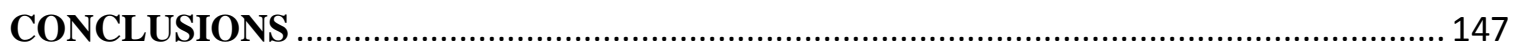

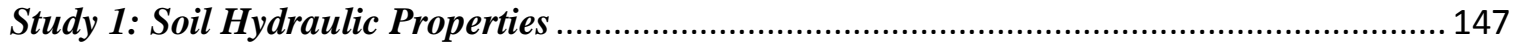

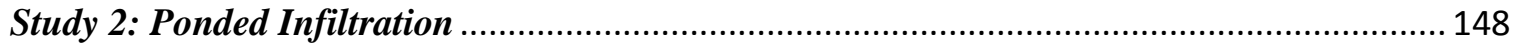

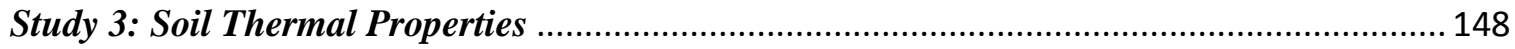

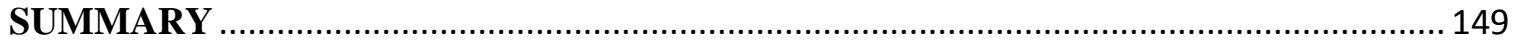

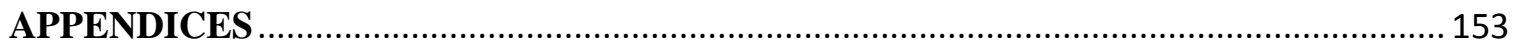

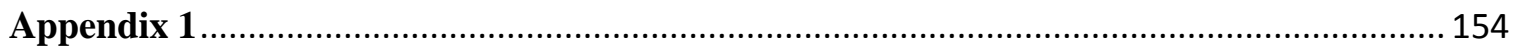

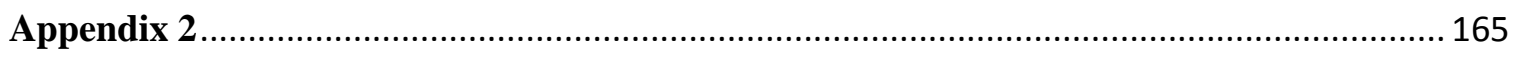

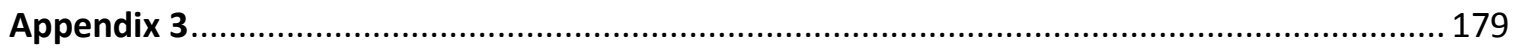

VITA 


\section{LIST OF TABLES}

Table 3.1 Selected soil physical and chemical properties of the Waldron silt loam at various soil depths and horizons 68

Table 3.2 Means and analysis of variance of saturated hydraulic conductivity (Ksat) and soil bulk density for the treatments and soil depths one week before cover crop termination ( 2 depths) and two weeks after cover crop termination (4 depths for the main sampling and 2 depths for comparison with samples taken one week before cover crop termination). Tillage also occurred two weeks after cover crop termination

Table 3.3 Means and analysis of variance of volumetric water content as a function of soil water pressure for the treatments and soil depths two weeks after cover crop termination and one week prior to cover crop termination. Tillage also occurred two weeks after cover crop termination.

Table 3.4 Means and analysis of variance of pore size distributions for the treatments and soil depths two weeks after cover crop termination and one week prior to cover crop termination. Tillage also occurred two weeks after cover crop termination.

Table 4.1 Selected soil physical and chemical properties of the Waldron silt loam at various soil depths and horizons.

Table 4.2 Selected soil physical and chemical properties of the Waldron silt loam at various soil depths and horizons. Means and standard deviation for bulk density and antecedent volumetric water content for treatments in 2014 and 2015

Table 4.3 Geometric means for saturated hydraulic conductivity $(K s)$ and sorptivity $(S)$ parameters estimated by the Parlange and Green-Ampt models in the cover crop with tillage (CC- 
Till), cover crop with no-till (CC-NT), no cover crop with tillage (NC-Till), and no cover with no-till (NC-NT) treatments in 2014 and 2015. 105

Table 4.4 Geometric means of quasi-steady state infiltration rate $(q s)$ and field-saturated hydraulic conductivity $(K f s)$ in the cover crop with tillage (CC-Till), cover crop with no-till (CCNT), no cover crop with tillage (NC-Till), and no cover crop with no-till (NC-NT) treatments in 2014 and 2015

Table 5.1 Soil physical properties as a function of soil depth for the study site (Mexico silt loam).

Table 5.2 Soil organic carbon (SOC), bulk density (Db) and volumetric water content (at selected water pressures).

Table 5.3 Thermal conductivity $(\lambda)$, volumetric heat capacity $\left(C_{V}\right)$ and thermal diffusivity $(D)$ at selected water pressures 


\section{LIST OF FIGURES}

Figure 3.1 (a) soil bulk density two weeks after cover crop termination (b) soil bulk density one week before cover crop termination (c) saturated hydraulic conductivity $\left(\mathrm{K}_{\text {sat }}\right)$ two weeks after cover crop termination and (d) $\mathrm{K}_{\text {sat }}$ one week before cover crop termination at various depths as influenced by cover crop with tillage (CC-Till), no cover crop with tillage (NC-Till), cover crop with no till (CC-NT), and no cover crop with no till (NC-NT) managements. Note: (a) Bar indicates least significant difference (0.05) value for bulk density. (b) The least significant difference (LSD) (0.05) value for Ksat is listed on the graph due to log scale.

Figure 3.2 Soil water retention curves at (a) 0 to $10 \mathrm{~cm}$ (b) 10 to $20 \mathrm{~cm}$ (c) $20-30 \mathrm{~cm}$ (d) 30 to $40 \mathrm{~cm}$ depths as influenced by cover crop with tillage (CC-Till), no cover crop with tillage (NC-Till), cover crop with no till (CC-NT), and no cover crop with no till (NC-NT) treatments two weeks after cover crop termination. Note: Bar indicates least significant difference (0.05) value for water retention.

Figure 3.3 Pore size distributions at various depths; (a-d) two weeks after cover crop termination (e-h) one week before cover crop termination as influenced by cover crop with tillage (CC-Till), no cover crop with tillage (NC-Till), cover crop with no till (CC-NT), and no cover crop with no till (NCNT) treatments. Note: Pore size classes include; macropores (> $1000 \mu \mathrm{m}$ diameter), coarse mesopores $(60-1000 \mu \mathrm{m})$, fine mesopores $(10-60 \mu \mathrm{m}$ diameter $)$, micropores $(<10 \mu \mathrm{m}$ diameter $)$.

Bar indicates least significant difference (0.05) value for pore size distribution. 78

Figure 4.1 The Parlange and Green-Ampt (G\&A) models fitted to measured ponded infiltration data for typical replicate under (A) cover crop with tillage (CC-Till), (B) cover crop with no tillage (CCNT), (C) no cover crop with tillage (NC-Till) and (D) no cover crop with no till (NC-NT) treatments for 2014. Please note that the y-axis scale is different for the four treatments. 107

Figure 5.1 Thermal conductivity $(\lambda)$ for cover crop (CC), no cover crop (NC), giant miscanthus (GM) and switchgrass (SG) treatments at (a) 0-10 cm, (b) 10-20 cm, (c) 20-30 cm depths and at four soil 
water pressures (d) 0, (e) -33, (f) -100, and (g) -300 kPa. Bar indicates least significant difference (LSD) at $\mathrm{p} \leq 0.05$ for $\lambda$ among various treatments.

Figure 5.2 Volumetric heat capacity $\left(\mathrm{C}_{\mathrm{V}}\right)$ for cover crop $(\mathrm{CC})$, no cover crop $(\mathrm{NC})$, giant miscanthus $(\mathrm{GM})$ and switchgrass (SG) treatments at (a) 0-10 cm, (b) $10-20 \mathrm{~cm}$, (c) 20-30 cm depths and at four soil water pressures (d) 0, (e) -33, (f) -100, and (g) -300 kPa. Bar indicates least square difference (LSD) at $\mathrm{p} \leq 0.05$ for $\mathrm{C}_{\mathrm{V}}$ among various treatments. 145

Figure 5.3 Thermal diffusivity (D) for cover crop (CC), no cover crop (NC), giant miscanthus (GM) and switchgrass (SG) treatments at (a) 0-10 cm, (b) 10-20 cm, (c) 20-30 cm depths and at four soil water pressures (d) 0, (e) -33, (f) -100, and (g) -300 kPa. Bar indicates least significant difference (LSD) at $\mathrm{p} \leq 0.05$ for $\mathrm{D}$ among various treatments. 146 


\title{
INFLUENCE OF COVER CROP AND TILLAGE MANAGEMENT PRACTICES ON SOIL PHYSICAL AND HYDRAULIC PROPERTIES
}

\author{
SAMUEL I. HARUNA \\ Dr. S. H. Anderson, Dissertation Supervisor
}

\begin{abstract}
Several agricultural land management practices, such as cover crops and tillage, can influence soil physical and hydraulic properties, soil health indicators and crop productivity. This study evaluated the influence of cover crops, tillage and perennial biofuel crops on soil physical and hydraulic properties. The objectives of this study included: (i) evaluate hydraulic properties for soils managed by cover crops and tillage, (ii) assess the influence of cover crops and tillage management on in situ water infiltration parameters, and (iii) evaluate thermal conductivity $(\lambda)$, volumetric heat capacity $\left(C_{V}\right)$ and thermal diffusivity $(D)$ for soils managed by perennial biofuel and cover crops. Two field sites were used for the study; the first and second objectives were conducted at Lincoln University's Freeman Research Center while the third objective was conducted at University of Missouri Bradford Research Center. The cover crop grown at Freeman Research Center was Cereal rye (Secale cereal L.), while Cereal rye, Hairy vetch (Vicia villosa subsp. villosa) and Austrian winter pea (Pisum sativum subsp. arvense) were grown at Bradford Research Center. The perennial biofuel crops at Bradford Research Center included giant miscanthus (Miscanthus x gigantus J.M. Geef \& Deuter ex Hodkinson \& Renvoize) and switchgrass (Panicum vergatum L.). The tillage treatments at Freeman
\end{abstract}


Research Center included tillage using a moldboard plow to a depth of $15 \mathrm{~cm}$ and no-till. The soil at Bradford Research Center was managed with no-till. Intact soil samples ( 76 by $76 \mathrm{~mm}$ ) were collected for objectives one and three with samples taken in 2014 and 2015, respectively. Infiltrometers were used to measure infiltration rates for objective two during 2014 and 2015. The physically-based Parlange and Green-Ampt infiltration models were fit to estimate saturated hydraulic conductivity $\left(K_{S}\right)$ and sorptivity $(S)$ parameters. Results showed that bulk density values for tillage were $13 \%$ lower compared with no-till management right after tillage. At the $0-10 \mathrm{~cm}$ soil depth, water content was significantly higher at the 0.0 and $-0.4 \mathrm{kPa}$ pressures for tillage compared with no-till management, right after spring tillage. However, this effect did not persist over time probably due to soil consolidation after some rainfall events. Tillage improved coarse mesopores by $32 \%$ compared with no-till; and this effect resulted in $87 \%$ higher saturated hydraulic conductivity values in tillage compared with no-till management, right after spring tillage. Cover crops improved macropores by $24 \%$ compared with no cover crop; this can potentially increase water infiltration and reduce runoff. As a result of higher macroporosity, saturated hydraulic conductivity was higher in the cover crop compared with no cover crop management. This study demonstrated that the effects of tillage in improving some soil hydraulic properties may not persist over time. The Parlange and Green-Ampt model appeared to fit measured infiltration data well with coefficient of variation $\left(\mathrm{r}^{2}\right)$ ranging from 0.92 to 0.99 . The $K_{S}$ parameter value estimated from the Parlange and Green-Ampt models in 2014 were $42 \%$ and 54\% higher in no-till compared with tillage management, respectively. In 2015, the $S$ parameter values estimated from the Parlange and Green-Ampt models were $82 \%$ and $90 \%$ higher in cover crop management 
compared to no cover crop management, respectively. This study showed that cover crops can improve water infiltration and may reduce water and nutrient runoff which can lead to enhanced agricultural productivity. Results of the third objective showed that perennial biofuel crops (giant miscanthus and switchgrass) had $11 \%$ higher $C_{V}$ at saturation compared to row crops (cover crops and no cover crops). Cover crops compared to no cover crop had $18 \%$ higher volumetric water content at saturation and $26 \%$ higher soil organic carbon; this led to $13 \%$ higher $C_{V}$ compared to no cover crops. Row crops had significantly higher $\lambda$ and $D$ compared to perennial biofuel crops. This study showed that perennial biofuel and cover crops can change soil thermal properties by reducing $\lambda$ and $D$ and increasing $C_{V}$; this indicates that these management systems can improve the ability of the soil to buffer against rapid heat change and better handle a more variable climate. Results from these studies showed that tillage may influence some soil properties temporarily; however, these influences may diminish over time. Cover crops can improve soil physical and hydraulic properties and soil health indicators and this can lead to improved productivity. However, longer-term studies are needed to evaluate these effects over time, especially with an increasingly changing climate. 


\section{CHAPTER 1}

\section{INTRODUCTION}

Soils are one of humankind's most important assets. Soils are mainly used for food and fiber production as well as biofuel production. It is therefore important that the soil be preserved from erosion and the quality of soil be maintained in order to produce optimal benefits. The physical and hydraulic properties of the soil have long been used as indicators of soil quality, especially with regards to water and nutrient holding capacity. For example, water and nutrient holding capacity of the soil can be estimated by measuring soil physical properties such as soil water characteristics, pore size distributions, soil structure and texture (Jabro et al., 2009, Raczkowski et al., 2012).

Soil quality can be affected by natural causes such as erosion, which can wash away soil materials. The management activities in agriculture (e.g perennial biofuel and cover crops, tillage, etc.) also have a profound effect on soil quality (Hamza et al., 2005). Tillage has been used in agriculture to prepare the seedbed; to incorporate fertilizers, manures, and residues into the soil; to relieve compaction; and to control weeds (Conant et al., 2006; Bhattacharyya et al., 2012). However, tilling the soil is disruptive and can promote soil structure degradation, dissipation of organic carbon as well as soil water and nutrient losses.

Conventional tillage is often classified into two types; primary and secondary. There is no strict boundary between them except for a loose distinction between tillage that is deep and more thorough (primary) and tillage that is shallower and more selective of location (secondary) (Flowers and Lal, 1998). Primary tillage, such as plowing, tends to 
produce a rough surface finish, whereas secondary tillage tends to produce a smoother surface finish, such as that required to make a good seedbed for many crops (Flowers and Lal, 1998; Reicosky, 2002).

Conventional tillage can temporarily alleviate soil compaction, increase availability of SOM and improve the soil temperature and moisture environment for seed germination in early spring (Stone et al., 1990; Doumbia et al., 2009; He et al., 2010). However, these benefits may be reversed over time. Conversely, no-till have been reported to help maintain SOM and aggregate stability (Rhoton, 2000), conserve soil moisture, maintain constant soil temperatures (Benegas et al., 1998) and improve water infiltration rates (Bhattacharyya et al., 2008). No-till also leads to better soil structure and an extensive system of macropores (Martino and Shaykewich, 1994), which benefits root growth (Lampurlanes et al., 2001).

Cropping systems include a community of plants that are managed by a farm unit to achieve various goals. These describe how a producer might grow crops. Cropping systems (which include cover cropping, crop rotation, and mixed cropping) may improve or decrease soil quality depending on the specific crop rotation, nutrient amendments and tillage practices employed (Sharma et al., 2009; Raczkowski et al., 2012). Concerns over global fossil fuel consumption and the possibility of increased global climate change has led to the inclusion of perennial warm season crops such giant miscanthus (Miscanthus $x$ gigantus J.M. Geef \& Deuter ex Hodkinson \& Renvoize) and switchgrass (Panicum vergatum L.) into cropping systems on the landscape as a means of alternative energy production (Gressel, 2008). Advantages of these perennial energy crops over annual energy crops such as cereals, sugar beet (Beta vulgaris subsp. vulgaris convar. vulgaris var. 
altissima) and rapeseed (Brassica napus L.) are the relatively high net fossil energy and greenhouse gas emission savings per unit of biomass and per unit of agricultural land (Boehmel et al., 2007). Besides their high energy output, these crops can also improve soil quality by increasing porosity, reducing bulk density, improving soil aggregation and increasing infiltration (Tufekcioglu et al., 1998; Ma et al., 2000; Mann et al., 2012).

Conventional crop production methods developed in the last few decades have been linked to negative effects on the environment, human health and safety, and long term soil fertility. Nitrate leaching and groundwater pollution, degradation of soil structure, and decreased surface infiltration of water are some of the common problems associated with conventional cropping systems (Sharma et al., 2009). However, the inclusion of cover crops into crop production cycles can ameliorate some of these problems and help improve soil quality (Dabney, 2001).

Cover crops provide soil conservation benefits by producing protective vegetative cover between the harvest of a previous year's crop, and the growing of a following year's crop. Cover crops have benefits of fixing atmospheric nitrogen, sequestering carbon into the soil, suppressing weeds and taking up excess soil nitrogen, thus reducing nitrogen loss (Moller et al., 2008).

The leaves of cover crops can also intercept rainfall and reduce splash detachment. It has been estimated (USDA-ARS Agriculture Handbook, 1997) that cotton (Gossipium hirsutum L.) and sunflower (Helianthus annuus L.) residue weighing $1,012 \mathrm{~kg} \mathrm{ha}^{-1}$ at harvest provides about $40 \%$ surface cover, while corn (Zea mays L.) and sorghum (Sorghum bicolor L.) weighing the same at harvest provides about 59\% surface cover. However, cover crops like alfalfa (Medicago sativa L.) and rye (Secale cereal L.), with the 
same residue weight at harvest, provide about $76 \%$ surface cover. Haramoto and Gallandt, (2004) reported that Brassicas (Brassica juncea L.) can provide more than $80 \%$ soil coverage when used as a winter cover crop. Cover crops have also been reported to increase soil organic matter by between $7-12 \%$ compared to no cover crop management (Kuo et al., 1997; Sainju et al., 2002; Villamil et al., 2006) and this can lead to improved soil aggregate formation and increased water infiltration (Folorunso et al., 1992; Joyce et al., 2002). This better soil cover and aggregation can be the difference in agricultural sustainability after a few decades.

Although several studies have evaluated the effects of tillage on soil physical properties and the effects of cover crops on these properties, few studies have evaluated their combined effects. In addition, no studies evaluated the effects of cover crops on soil thermal properties, an important group of physical properties. Therefore, this study evaluated how cover crop and tillage management practices influences soil physical and hydraulic properties.

\section{Objectives}

The objectives of this study were evaluated in three sub-studies as outlined below. Specific objectives were developed for each study.

Study 1. Study was entitled "soil hydraulic properties: influence of tillage and cover crops" with the specific objective of assessing the influence of cover crops and tillage management on soil hydraulic properties including; bulk density, water retention, pore size distributions and saturated hydraulic conductivity.

Study 2. This study was referred to as "in situ infiltration as influenced by cover crop and tillage management" with the specific objective of evaluating the influence of cover 
crop and tillage management on water infiltration parameters (sorptivity, saturated hydraulic conductivity, quasi-steady infiltration rate and field saturated hydraulic conductivity).

Study 3. This study was entitled "soil thermal properties influenced by perennial biofuel and cover crop management" with the specific objective of evaluating the effects of perennial biofuel and cover crops on volumetric water content, soil organic carbon, thermal conductivity, volumetric heat capacity and thermal diffusivity.

All three studies were written independently in the format of journal manuscripts for publication purposes. Study 1 has been accepted by Pedosphere for publication. Study 2 has been accepted for publication by Journal of Soil and Water Conservation. Study 3 has been accepted for publication by Soil Science Society of America Journal. 


\section{REFERENCES}

Benegas, C.P. 1998. Effect of no-tillage system on chemical and physical characteristics of soil in Paraguay. No-tillage cultivation of soybean and future research needs in South America. Ibaraki: JIRCAS, Ministry of Agriculture, Forest and Fishery, pp.19-28.

Bhattacharyya, R., M.D., Tuti, S., Kundu, J.K., Bisht, and J.C., Bhatt. 2012. Conservation tillage impacts on soil aggregation and carbon pools in a sandy clay loam soil of the Indian Himalayas. Soil Sci. Soc. Am. J. 76: 617-627.

Bhattacharyya, R., S., Kundu, S.C., Pandey, K.P., Singh, and H.S., Gupta. 2008. Tillage and irrigation effects on crop yields and soil properties under the rice-wheat system in the Indian Himalayas. Agricult. Water Mgt. 95: 993-1002.

Boehmel, C., I., Lewandowski, and W., Claupein. 2008. Comparing annual and perennial energy cropping systems with different management intensities. Agricult. Syst. 96(1):224-236.

Conant, R.T., M., Easter, K., Paustian, S., Swan, and S., Williams. 2007. Impacts of periodic tillage on soil carbon stocks: A synthesis. Soil Tillage Res. 95:1-10.

Dabney, S.M., J.A. Delgado, and D.W. Reeves. 2001. Using Winter Cover Crops to Improve Soil and Water Quality. Commun. Soil Sci. Plant Anal. 32(7-8): 12211250. doi:10.1081/CSS-100104110.

Doumbia, M., A., Jarju, M., Sène, K., Traoré, R., Yost, R., Kablan, K., Brannan, A., Berthe, C., Yamoah, A., Querido, and P.C., Traoré. 2009. Sequestration of organic carbon in West African soils by Aménagement en Courbes de Niveau. Agron. Sustain. Develop. 29: 267-275.

Flowers, M.D., and R., Lal. 1998. Axle load and tillage effects on soil physical properties and soybean grain yield on a Mollic Ochraqualf in northwest Ohio. Soil Till. Res. 48: 21-35.

Folorunso, O.A., D.E., Rolston, T., Prichard, and D.T., Loui. 1992. Soil surface strength and infiltration as affected by winter cover crops. Soil Tech. 5: 189-197.

Gressel, J. 2008. Transgenics are imperative for biofuel crops. Pl. Sci. 174: 246-263. doi:10.1016/j.plantsci.2007.11.009.

Haramoto, E.R., and E.R. Gallandt. 2004. Brassica cover cropping for weed management: A review. Renew. Agric. Food Syst. 19: 187-198. 
He, J., H., Li, N.J., Kuhn, Q., Wang, and X., Zhang. 2010. Effect of ridge tillage, notillage, and conventional tillage on soil temperature, water use, and crop performance in cold and semi-arid areas in Northeast China. Soil Res. 48: 737744.

Ide, G., and G., Hofman. 1990. The influence of subsoiling a plough-sole on the yield of agricultural crops. Soil Techn. 3: 259-268.

Jabro, J.D., U.M., Sainju, W.B., Stevens, A.W., Lenssen, and R.G., Evans. 2009. Long term influences on soil properties under dry land conditions in northeastern Montana. Agron. Soil Sci. J. 55: 633-640.

Joyce, B.A., W. W., Wallender, J.P., Mitchell, L.M., Huyck, S.R., Temple, P.N., Brostrom, and T.C., Hsiao. 2002. Infiltration and soil water storage under winter cover cropping in California's Sacramento Valley. Transactions of ASAE 45: 315-326.

Kuo, S., U.M., Sainju, and E.J., Jellum. 1997. Winter cover crop effects on soil organic carbon and carbohydrate in soil. Soil Sci. Soc. Am. J. 61: 145-152.

Lampurlanés, J., P., Angás, and C., Cantero-Martınez. 2001. Root growth, soil water content and yield of barley under different tillage systems on two soils in semiarid conditions. Field Crops Res. 69: 27-40.

Ma, Z., C.W. Wood, and D.I., Bransby. 2000. Impacts of soil management on root characteristics of switchgrass. Biomass Bioenergy 18: 105-112. doi:10.1016/S0961-9534(99)00076- 8 .

Mann, J.J., J.N. Barney, G.B. Kyser, and J.M. DiTomaso. 2012. Root System Dynamics of Miscanthus $\times$ giganteus and Panicum virgatum in Response to Rainfed and Irrigated Conditions in California. BioEnergy Res. 6: 678-687. doi:10.1007/s12155-012-9287-y.

Martino, D.L., and C.F., Shaykewich. 1994. Root penetration profiles of wheat and barley as affected by soil penetration resistance in field conditions. Can. J. Soil Sci. 74: 193-200.

Möller, K., W., Stinner, and G., Leithold. 2008. Growth, composition, biological N2 fixation and nutrient uptake of a leguminous cover crop mixture and the effect of their removal on field nitrogen balances and nitrate leaching risk. Nutr. Cycl. Agroecosyst. 82: 233-249. 
Raczkowski, C.W., J.P., Mueller, W.J., Busscher, M.C., Bell, and M.L., McGraw. 2012. Soil physical properties of agricultural systems in a large-scale study. Soil Till. Res. 119: 50-59.

Reicosky, D.C. 2002. Long term effect of moldboard plowing on tillage induced $\mathrm{CO}_{2}$ loss. In Kimble, J.M., Lal, R., Follet, R.F. (eds). Agricultural practices and policies for carbon sequestration in soil. CRC/Lewis, Boca Raton, FL, pp. 8797.

Rhoton, F.E. 2000. Influence of time on soil response to no-till practices. Soil Sci. Soc. Am. J. 64: 700-709.

Sainju, U. M., and B.P., Singh. 2008. Nitrogen storage with cover crops and nitrogen fertilization in tilled and non-tilled soils. Agron. J. 100: 619-627.

Sharma, S.N., R., Prasad, M.K., Dwivedi, S., Kumar, M.R., Davari, and M., Ram. 2009. Effects of cropping system on production and chemical and biological properties of soil. Arch. Agron. Soil Sci. 55: 429-438.

Stone, J.A., T.J., Vyn, and N.D., Clarke. 1990. Ridge tillage for corn and soybean production on clay and clay-loam soils in southwestern Ontario-a review. Soil Tillage Res. 18: 219- 230.

Tufekcioglu, A., J.W. Raich, T.M. Isenhart, and R.C. Schultz. 1998. Fine root dynamics, coarse root biomass, root distribution, and soil respiration in a multispecies riparian buffer in Central Iowa, USA. Agrofor. Syst. 44: 163-174.

United States Department of Agriculture (USDA). 2013. National Agricultural Statistics Service (NASS) agricultural census report.

https://www.agcensus.usda.gov/Publications/2012/Full_Report/Volume_1,_Cha pter_1_State_Level/Missouri/st29_1_064_064.pdf. (verified March 3, 2017).

USDA-ARS Agricultural Handbook (1997). Predicting soil erosion by water: a guide to conservation planning with the revised universal soil loss equation (RUSLE). Superintendent of Documents, Mail Stop: SSOP, Washington, DC 20402-9328. ISBN0-16-048938-5. Available http://www.ars.usda.gov/SP2UserFiles/Place/64080530/RUSLE/AH_703.pdf. (verified March 3, 2017).

Villamil, M.B., G.A., Bollero, R.G., Darmody, F.W., Simmons, and D.G., Bullock. 2006. No-Till Corn/Soybean Systems Including Winter Cover Crops. Soil Sci. Soc. Am. J. 70: 1936-1944. 


\section{CHAPTER 2}

\section{LITERATURE REVIEW}

Agriculture provides food, fiber, and fuel for man and animals. As the world's population has and continues to increase, it has become very imperative to increase production to meet these demands. In order to do this, proper agricultural land management practices should be in place. These practices must, among other things, improve soil quality, improve crop yield, and reduce the environmental impact of agricultural practices. For many decades, tillage and various cropping systems, such as cover cropping, have been used as a means of improving soil quality and crop yield (Pieters, 1927; Periera, 1975). However, recent studies, in the past few decades, suggest that tillage practices may be more harmful to the soil than initially thought (Balesdent et al., 1990; Lal, 1997; Franzleubber et al., 2004; Alvarez and Steinbach, 2009; Zhang et al., 2012). Long-term tillage practices have been linked to reduction in crop yield and soil quality, as well as increasing the susceptibility of farmland to environmental impacts such as erosion (Mahli et al., 2006). Cropping systems may affect soil quality depending on the specific crop rotation practice employed. This chapter describes and reviews previous results on the influence of cover crops and tillage management practices on soil physical and hydraulic properties.

\section{TILLAGE AND COVER CROPS}

\section{Tillage}

Tillage is the agricultural preparation of the soil by mechanical agitation of various types such as digging, stirring and overturning. Throughout the history of human civilization, soil tillage has been integral to crop production. Tillage was initially practiced 
as a means of relieving soil compaction, enhancing seedbed preparation, improving soil aeration, homogenizing topsoil and mixing organic matter (Periera, 1975). With recent research, however, it has been discovered that long-term tillage practices may reduce soil quality by destroying soil structure (Franzeleubbers et al., 2004; Alvarez and Steinbach, 2009). Some tillage practices include conservation tillage, intensive tillage, ridge tillage, alternate tillage, and no-till.

Conservation tillage systems are methods of tillage which leave a minimum of $30 \%$ of crop residues on the soil surface or at least $1,100 \mathrm{~kg} \mathrm{ha}^{-1}$ of small grain residues on the surface during the critical soil erosion period (Angers et al., 2009). This reduces the kinetic energy of raindrops, and may lead to reduced soil and nutrient loss. Conservation tillage systems also benefit farmers by reducing fuel consumption and soil compaction. This was used on about $38 \%$, the equivalent of $440,000 \mathrm{~km}^{2}$, of all US cropland, planted as of 2007 according to the United States Department of Agriculture (USDA) (Chatskikh et al., 2009). Conservation tillage reduces some of the negative impacts of tillage, preserves soil resources and can lead to accrual of much of the soil carbon lost during conventional tillage (Conant et al., 2006; Bollero et al., 2006; Chatskikh et al., 2009).

Intensive tillage systems leave less than $15 \%$ crop residue cover or less than $560 \mathrm{~kg}$ $\mathrm{ha}^{-1}$ of small grain residue (Angers et al., 2009). This type of tillage system is often referred to as conventional tillage; however, as reduced and conservation tillage systems have been more widely adopted, it is often not as appropriate to refer to this type of system as conventional (Angers et al., 2009). This tillage system (intensive tillage) often involves multiple operations with implements such as a moldboard plow, disk, and/or chisel plow. Then a finishing operation with a harrow, rolling basket, and cutter can be used to prepare 
the seedbed. Moldboard plowing involves the inversion of soil with implements attached to animals or tractors for tilling the ground. A chisel plow uses metal shanks, for tilling and loosening the soil (Jokela et al., 2011).

Ridge-till, a tillage system involving scalping and planting on ridges built during cultivation of the previous year's crop, usually involves spring-planted row crops grown with a combination of herbicides and at least one cultivation (Conant et al., 2007). Intensive land cultivation has often caused soil degradation, for whole regions in some cases; and has decreased the quality of groundwater and surface water; and contributed to air pollution, including emissions of greenhouse gases (Chatskikh et al., 2009).

Long-term tillage practices can lead to a decline in soil quality. It has been reported that following long-term tillage, soil carbon stocks can be reduced by as much as $20 \%$ 50\% (Simon et al., 2009; Christopher et al., 2009; Ochsner et al., 2011). The type and frequency of tillage and associated residue management in a cropping system can affect the accumulation of soil organic matter and other factors related to soil quality (Hamza et al., 2005).

No-till systems are generally recommended as effective management systems for maintaining and even improving soil productivity and quality (Raper and Bergtold, 2007; Shi et al., 2012). Reduced mechanical disturbance associated with no-till often leads to improved soil structure, as indicated by more macro-aggregation, and more total and mineralizable carbon, but these effects tend to be limited to the top soil (Jokela et al., 2011). No-till systems also have the advantage of reducing soil erosion and surface runoff (Nyakatawa et al., 2000; Zhang et al., 2009), decreasing time and cost (fuel and labor) 
requirements for land preparation (Raper and Bergtold, 2007; McLaughlin et al., 2008), and slowing soil organic matter loss (Koch and Stockfisch, 2006).

\section{Cropping Systems}

A cropping system is an integration of various agricultural practices including shifting cultivation, crop rotations, cover cropping, mixed farming, etc. Midwestern United States cropping systems include a variety of crops and crop rotations; continuous corn (Zea mays), short rotations of corn with soybean (Glycine max) or other annual grains, or longer rotations that include multiple years of perennial forages/bio-energy crops (Jokela et al., 2011). The aim of the various cropping systems in agriculture is to optimize economic returns and possibly enhance soil quality.

The implementation of different cropping systems in agriculture has been around since planting and harvesting itself. Much attention was not given to cropping systems until the early 1900 's, when there was a need to increase food production and maximize land use (Sharma et al., 2009). In the past few decades, a move towards sustainability in agriculture has also developed, integrating ideas of socio-economic justice and conservation of resources and the environment within a farming system. This has led to the development of many responses to the conventional agriculture approach, including organic agriculture, urban agriculture, community supported agriculture, ecological or biological agriculture, integrated farming and holistic management, as well as an increased trends toward agricultural diversification (Umiker et al., 2008).

Cropping systems have the potential to provide several benefits to farmers and have been studied both in the context of forage production for cattle and bioenergy feed stock production (Ochsner et al., 2011). Experiments have shown that a double-cropping system 
can result in $6-10 \%$ increase in total biomass production relative to corn silage alone (Jokela et al., 2011; Ochsner et al., 2011).

Perennial biofuel crops like switchgrass and miscanthus, due to their year-round surface cover, may protect soil from erosion, improve soil properties, soil productivity, and wildlife habitat and diversity (Blanco-Canqui, 2010). Roots and earthworm burrows under perennial biofuel crops can penetrate compacted soil layers and change the pore structure, increasing water infiltration and storage at lower depths (Katsvairo et al., 2007). Bharati et al. (2002) reported that cumulative water infiltration after $1 \mathrm{hr}$ was five times greater in switchgrass than in row crops and pasture after 6 yrs of management. Perennial biofuel crops can also influence soil water retention and unsaturated water flow. Rachman et al. (2004) reported that saturated hydraulic conductivity and volumetric water content (at 0 $\mathrm{kPa}$ ) were significantly higher in switchgrass hedges compared to row crops. In addition to their potential as biofuel, these crops may also serve as a valuable animal feedstock, which is particularly important in years of drought (Craine et al., 2010). The practice of various cropping systems has been shown to improve the physical and hydraulic properties of the soil.

\section{Cover Crops}

Cover crops have been referred to as crops planted primarily to manage soil health, weeds, water quality, biodiversity, control pests and diseases (Lu et al., 2000). Most cover crops are not grown solely for economic benefits, but for the ecosystem benefits they provide. Yunusa and Newton (2003) referred to cover crops as 'primer plants'; crops grown to condition the soil for the subsequent crops. 
Growing cover crops has been a popular practice in crop production throughout history (Reeves, 1994). They were originally grown as green manures, serving as a mulch and soil amendment, and were later incorporated into soil to improve fertility (Kasper and Singer, 2011). Utilizing green manures as a source of nitrogen was a standard practice in the US until the mid-twentieth century, when synthetic nitrogen fertilizers became widely available (MacRae and Mehuys, 1985). Currently, the use of synthetic nitrogen fertilizers dominates grain crop production, limiting the use of green manure cover crops.

Cover crops have benefits of fixing atmospheric nitrogen, sequestering carbon into the soil, and suppressing weeds. Moller et al. (2008) estimated that leguminous cover crops could fix between $60-80 \mathrm{~kg} \mathrm{ha}^{-1}$ of nitrogen into the soil compared with non-leguminous cover crops. Non-leguminous cover crops can also immobilize excess soil nitrogen, thus reducing nitrogen loss (Umiker et al., 2009). Cover crops can also reduce weeds by maintaining cover at critical times. Fisk et al., (2001) reported that using an annual medic or a clover (Medicago Spp.) cover crop in no-till corn reduced winter annual weeds by between $41-81 \%$ compared with no cover crop. Cover crops can enhance soil quality through addition of organic matter when incorporated into the soil, helping to reduce compaction and increase infiltration; thus reducing runoff and immobilizing soil nitrogen, and reducing non-point source pollution (Dabney et al., 2001). Wyland et al., (1996) reported a 65-70\% reduction in nitrate leaching when cover crops replaced winter fallow. Cover crops can also increase nutrient uptake (Umiker et al., 2009) and reduce soil erosion from splash detachment by reducing the kinetic energy of raindrops.

Despite its importance, only about $3 \%$ of farmers incorporate cover crops into their farming practices mostly because of the cost of seeds, labor, planting, and terminating 
equipment and probable competition for available water (personal communication, Lara Bryant, Agriculture Program Coordinator, National Wildlife Federation). Recent reports suggest, however, that current cover crop usage is increasing (North Central Sustainable Agriculture Research \& Education, 2015).

\section{SOIL PHYSICAL AND HYDRAULIC PROPERTIES}

Soil physical and hydraulic properties are important factors that can determine agricultural productivity and environmental sustainability. These properties influence the water and nutrient holding capacity of the soil and they serve as indicators of soil quality. Some of these properties include bulk density, pore size distributions, soil water retention, saturated hydraulic conductivity, water infiltration and thermal properties.

\section{Soil Bulk Density and Compaction}

Bulk density is a basic parameter usually used to describe soil compactness and for estimates of permeability. Bulk density determination, just like most soil chemical properties analysis, usually excludes the coarser stone and gravel fractions (Heuscher et al., 2005). The bulk density of in situ developed mineral soils, except for compaction effects, is assumed to increase with soil depth (Nemes et al., 2010).

If a soil is compacted, bulk density increases and porosity decreases correspondingly. However, absolute values of bulk density are unsuitable for characterizing soil compactness with respect to crop yield when comparing different soils, as optimum and critical limits of bulk density for crop growth strongly depend upon soil type (Keller and Håkansson, 2008), i.e. different values of bulk density are optimum for different soils, as demonstrated by Reichert et al. (2009). A bulk density that indicates a compact state in one soil may imply a loose state in another (Håkansson, 1990). Therefore, 
relative bulk density has been suggested to describe the compactness of soil. The relative bulk density is generally obtained as the ratio of actual field bulk density (i.e. bulk density measured either directly in the field or on undisturbed soil samples collected in the field) to a reference bulk density (Håkansson, 1990).

One of the major negative consequences of modern agricultural production is soil physical degradation resulting in soil compaction and erosion, which is attributed to deep and intensive tillage practices (Poesse, 1992; Bronick and Lal, 2005; Hamza and Anderson, 2005). Soil compaction is defined as: "the process by which the soil grains are rearranged to decrease void space and bring them into closer contact with one another, thereby increasing the bulk density', (Soil Science Society of America, 2008). It is related to soil aggregation because compaction alters the spatial arrangement, size and shape of clods and aggregates and consequently the pore spaces both inside and between these units (Defossez and Richard, 2002).

Soil compaction seriously threatens agricultural production in some areas. Soil compaction at the soil surface can be remediated by soil tillage, plant root growth and biological activity. However, deep soil compaction under the plow layer can decrease the growth of plants by reducing rooting depth and plant available soil water, which often results in a decrease of crop yield (Ide and Hofman, 1990) and is extremely difficult to remediate. The extent of compacted soil worldwide is estimated at 68 million hectares of land from vehicular traffic alone (Flowers and Lal, 1998). Although farming systems have improved significantly to cope with the new pressures associated with intensive agriculture, the structure of many otherwise healthy soils has deteriorated to the extent that crop yields have been reduced. 


\section{Pore Size Distributions}

Soil pores can be characterized, depending upon their effective diameters, as macropores (> 1,000 $\mu \mathrm{m}$ effective diameter), coarse mesopores (60-1,000 $\mu \mathrm{m}$ effective diameter), fine mesopores $(10-60 \mu \mathrm{m}$ effective diameter) and micropores $(<10 \mu \mathrm{m}$ effective diameter) (Anderson et al., 1990). Macroporosity represents inter-aggregate porosity, characterized by a large degree of structural continuity. Mesopore systems consist of inter-aggregate pores with less continuity and higher tortuosity (Messing and Jarvis, 1993). The choice of an effective size to delimit macropores is often more related to details of experimental technique than to considerations of flow processes (Luxemore, 1981; Beven and Germann, 1982).

\section{Soil Water Retention}

Soil water controls plant growth and influences a variety of soil processes including erosion, chemical exchange, microbial activity, transport of solutes and water, energy balance of the soil-plant system, and pedo-genesis (Western et al., 2003). The relationship between water content and water potential determines, in part, the nature of these effects. Soil water represents a small portion of the water in the hydrologic cycle. However, due to its vital role in the ecosystem, the temporal and spatial variability of soil water has a controlling influence on ecosystem processes at a variety of scales (Western et al., 2003).

Water retention is a hydro-physical property of soil that can be described by the dependence between soil water content and soil water potential (Walczak et al., 2006). Soil water retention denotes the ability of the soil to retain water at a specific pressure and it is often represented in the form of a graph. Soil water retention is important as it highlights the ability of the soil to retain water for plant use between periods of infiltration. The fact 
that two soils have the same matric potential does not mean that they possess the same amount of water; therefore, not all of this soil water is available for crops (Walczak et al., 2006). Agronomically, the most important factor on soil water content is the water available for crop use; the plant available water content. A common requirement is to know plant available water in non-saturated soil through the water retention curve (Perez-de-losReyes et al., 2011). The water retention curve can be constructed from experimental measurements or from empirical equations known as pedo-transfer functions (Wosten et al., 2001).

The main properties of the soil that influence the water retention curves are texture and structure (Nimmo, 1997). At high potential values, the amount of water retained depends on the capillary effect and on the distribution of pore size; which is greatly affected by the structure of the soil (Kironchi et al., 1995; Pachepski and Rawls, 2003; Juarez et al., 2006; Juhasz et al., 2007). Conversely, at low potential values, retention is due to the increase in absorption, more influenced by texture and specific soil surface materials (Kironchi et al., 1995; Nimmo, 1997; Juarez et al., 2006). Williams et al. (1983) showed that the factors influencing water retention properties are the distribution of the particle size, the clay mineralogy, the content of organic matter and the bulk density of the soil; which are properties related to the texture and structure. Kironchi et al. (1995) also highlighted the type of clay as an important factor in water retention.

\section{Saturated Hydraulic Conductivity $\left(K_{\text {sat }}\right)$}

Hydraulic conductivity of saturated soil is an important soil property that controls water infiltration and surface runoff, leaching of pesticides from agricultural lands, and migration of pollutants from contaminated sites to the ground water (Gimenez et al., 1997). 
Saturated hydraulic conductivity depends strongly on soil texture and structure and therefore can vary widely spatially (Logsdon and Jaynes, 1996).

Hydraulic conductivity also shows a temporal variability that depends on different interrelated factors, including soil nature and stability, climate, land use, dynamics of plant canopy and roots, and tillage operations (Prieksat et al., 1994). In a study by Seobi et al. (2005) on the influence of grass and agroforestry buffer strips on soil hydraulic properties of an Albaqualf, they reported that saturated hydraulic conductivity $\left(\mathrm{K}_{\mathrm{sat}}\right)$ was higher for agroforestry buffer treatment compared with grass buffer and row crop treatments for all depths except in the $10-20 \mathrm{~cm}$ depth where it was only higher than the grass buffer treatment. Kumar et al (2008) reported 15.4 and 19.7 times higher $\mathrm{K}_{\text {sat }}$ values in fields with agroforestry buffers than continuously and rotationally grazed pastures, respectively. This was attributed to lower soil bulk density and higher macroporosity in the agroforestry buffers.

\section{Infiltration}

Water infiltration refers to the movement of water into the soil and it is an important factor in water conservation strategy, runoff and erosion control (Shukla, 2003) and crop productivity. Infiltration is governed by two factors; capillarity and gravity. Smaller pores can move water with or against gravity and influence the infiltration rate of the soil (Shukla, 2014). Larger pores move water under gravity and control a significant amount of the infiltration. Lin et al. (1996) reported that $10 \%$ of macropores (> 1,000 $\mu$ m diameter) and mesopores $(10-1,000 \mu \mathrm{m}$ diameter) contributed about $89 \%$ of total water flux.

Infiltration rate is affected by both natural and anthropogenic factors. The duration of the infiltration event is an important factor affecting infiltration. The infiltration rate is 
usually higher initially, unless the soil is wet, and decreases with time until it becomes nearly constant. This may be because of the decrease in the soil water potential gradient as the soil becomes wet. Thus, antecedent soil water content plays an important role in infiltration by significantly influencing the sorptivity of the soil; the soil's ability to absorb and desorb water under capillarity (Shukla, 2014).

Soil texture also has an important influence on water infiltration rate. Infiltration rates generally reduce with a higher proportion of fine particles (clays and silts). Surface conditions are also important for infiltration. Good soil structure promotes infiltration, while bad structure diminishes it. The presence of an impeding soil layer with a different texture than the above layer can also greatly affect the infiltration rate. If the impeding layer is predominantly clayey, the lower hydraulic conductivity associated with clays slows down the flow of water.

Land use and management systems greatly influence water infiltration into the soil. Generally, management practices that increase pore continuity, connectivity, size and distribution also tend to improve water infiltration. Due to the initial increase in porosity and lower water content, tillage has been reported to increase infiltration compared with no-till management (Alegre et al., 1991; Logsdon et al., 1993). However, lower infiltration has been noticed under tillage management compared with no-till after long-term management due to increased potential for surface crusting, loss of soil organic matter and structure, and breakdown of soil aggregates (Shipitalo and Edwards, 1996). Conversely, no-till can increase soil organic matter and aggregation and increase infiltration into the soil compared with tillage (Shukla, 2003; Shukla and Lal, 2005). Management practices 
like perennial biofuel and cover crops can improve porosity, increase soil organic matter and aggregation, transpire water and increase infiltration (Joyce et al., 2002).

\section{Soil Thermal Properties}

Heat transport through the soil is an important factor for ecosystems (Shukla, 2014). The primary source of energy in an ecosystem is from the sun. The radiation coming to the earth's surface raises the temperature of the air and soil. Depending on abiotic factors, such as water content, texture, structure, density and thermal properties of the soil, changes in soil temperature may take place at different soil depths and time (de Vries, 1975). The type of vegetation growing on the soil can also have a major effect on heat transport through the soil. An open canopy has an important influence in modifying the microclimate and soil surface conditions, characterized by localized conditions of soil water and thermal regimes within canopies, thus influencing the soil water dynamics in unsaturated soils (Deb et al., 2011).

Heat transfer through a soil profile essentially denotes movement of heat from the soil surface to deeper layers or heat loss from subsoil layers to the surface. Heat transfer normally occurs from warmer soil layers to cooler soil layers. Thus, heat transfer through the soil is affected by season and time of day. For example, during the summer, heat transfer is from upper soil layers to deeper soil layers, and during winter periods, this process is reversed (Kiehl and Trenberth, 1997). Heat transfer also changes direction during the day and night, depending on the air-soil surface temperature. Heat transfer is a very dynamic process.

Heat transfer through the soil is dependent on the heat capacity and conductivity of different soil layers and constituents (Bristow, 2002). Since both heat capacity and 
conductivity of soil is dependent on soil water content, heat transfer is strongly influenced by soil water content (Scanlon et al., 2005). In addition, this process is also influenced by soil organic carbon content and density; this process is also affected the amount of energy arriving at the soil surface which is influenced by type of vegetation, and topography. Heat transfer usually increases with an increase in soil bulk density or compaction due to the increased contact between soil minerals (Bristow, 2002). Wet soils with higher organic carbon content have higher heat capacity and are more buffered relative to changes in temperature compared to dry soils with lower organic carbon content due to their lower heat capacity. Knowledge of heat transport through soils is important and this process may affect crop productivity in a changing global climate.

\section{TILLAGE EFFECTS ON SOIL PHYSICAL AND HYDRAULIC PROPERTIES}

Two of the most commonly measured soil properties affecting hydraulic properties and processes are soil bulk density and porosity. Soil bulk density and porosity are also fundamental to soil compaction and related agricultural management issues. Thus, the importance of these properties is readily apparent to soil scientists. An understanding of soil pore geometry and structure is fundamental to identifying the effects of tillage on soil physical and hydraulic properties.

\section{Soil Bulk Density}

Some tillage operations can disrupt soil structure and affect soil bulk density. Jokela et al. (2011) conducted an 18-year experiment in the Midwest on cropping system effects on soil properties and on a soil quality index in Wisconsin. They found a significantly higher bulk density in tilled compared to no-till plots. They attributed this difference to multiple trips with harvesting equipment for the tilled treatment and infrequent tillage for 
the no-till treatment. They also found lower soil water content in tillage management compared to no-till. They attributed this difference to the extended evaporation of soil water because of tillage practices and aerating the soil. Similarly, Oschner et al. (2011) reported higher bulk density under chisel tillage management compared to no-till.

Conversely, in a study on the effects of tillage on the physical properties of agricultural organic soils of north central Ohio conducted by Elder and Lal (2008), soil bulk density of no-till and fallow treatments were higher compared to moldboard plow treatments at the 0-10 cm depth, right after tillage. Hamza et al. (2005), D'Haene et al. (2008) and Eltaif et al. (2011) reported similar trends in bulk density for mineral soils. One of the reasons for the differences in bulk density results reported by these researchers could be due to the time of sampling; bulk density immediately after tillage is lower while it may increase over time due to the disturbance of soil structure. Soil crusting develops faster under tillage management compared to no-till and this can increase bulk density (Shipitalo and Edwards, 1996).

\section{Pore Size Distributions}

Tillage management can lead to a redistribution of soil pore sizes. From their experiment, Raczkowski et al. (2012) reported that macroporosity was greater in conventional tillage compared to a no-till system, but no significant differences existed in microporosity. They also reported higher total porosity in tillage compared to no-till systems. Hill et al. (1985) and Kay and VandenBygaart (2002) reported similar findings. Kay and VandenBygart (2002) attributed this higher porosity to soil mixing through tillage.

In their experiment, Schwen et al. (2011) found that total porosity was very similar between conventional tillage and reduced tillage, but significantly higher than a no-till 
treatment, with overall means of $0.50,0.50$, and $0.46 \mathrm{~cm}^{3} \mathrm{~cm}^{-3}$, respectively. These researchers also reported lower bulk density under tillage compared to no-till management right after tillage. They suggested that the greater soil bulk density and smaller total porosity under no-till was likely due to natural compaction, as soil in this treatment was not artificially loosened by tillage for 12 years. Strudley et al. (2008) and Alvarez et al. (2009) reported similar findings.

\section{Soil Water Retention and Saturated Hydraulic Conductivity}

Water storage can change in conjunction with water flux parameters as affected by tillage, and the response to tillage may be equally uncertain as compared to bulk density. Chang and Lindwall $(1989,1990,1992)$, in their studies over 10 years on the effect of notill management on a loam soil in Canada with continuous winter wheat (Triticum aestivum L.), observed lower water-holding capacity in tilled compared with no-till management at the 3 to $6 \mathrm{~cm}$ depth interval despite no discernible tillage effects above and below this zone. Brandt (1992) investigated 12 years of conventional till (CT) versus no-till (NT), and found that NT resulted in greater soil water content compared to CT in 9 of 36 cases and no significant differences in the rest. Likewise, Mahboubi et al. (1993) detected greater water holding capacity in NT compared to CT management on two Ohio silt loam soils during a 28-year study. Azooz and Arshad (2001) measured water retention at six water pressures from -5 to $-160 \mathrm{kPa}$. The rate of soil drying in the top $30 \mathrm{~cm}$ was significantly greater in CT than NT, while the rate of wetting (based on a recharge coefficient) was significantly greater in NT.

No-till systems exhibit variations in saturated hydraulic conductivity $\left(K_{\text {sat }}\right)$ response. Horne et al. (1992) extended a tillage study (Ross and Hughes, 1985) for 10 years 
under NT, minimum till (MT), and CT (using moldboard plow) on a silt loam soil in New Zealand and discovered that $K_{\text {sat }}$ values in soil cores taken from the top $10 \mathrm{~cm}$ immediately before seedbed preparation did not differ significantly between the tillage treatments. This result was obtained despite declines in total porosity and infiltration rates, and increased bulk density and aggregate size under NT compared with MT and CT right after tillage. Long-term (28-year) studies on two Ohio silt loam soils by Mahboubi et al. (1993) showed significantly greater mean hydraulic conductivity in NT compared to chisel and moldboard plowing. Azooz and Arshad (1996, 2001) studied the long-term effects of CT and NT practices on two soils (silt loam and sandy loam gray Luvisols) of the northwestern Canadian prairies and concluded that long-term NT practices can maintain soil pore structure and continuity, which can contribute to significantly greater hydraulic conductivity in NT than in CT management.

\section{Infiltration}

A number of researchers in various parts of the world has documented No-till effects on infiltration capacity and sorptivity. In southeastern Australia, NT resulted in higher sorptivity in duplex soils compared to CT (Carter and Steed, 1992), while in New Zealand, NT resulted in the lowest infiltration rates compared with MT and CT on a silt loam during a 10-year study (Horne et al. (1992). Azooz and Arshad (1996, 2001) measured significantly lower ponded infiltration rates under CT compared to NT on a silt and sandy loam gray luvisols of the northwestern Canadian prairies, which contrasts with the results of Alegre et al. (1991) who summarized results of multiple studies in Latin America documenting reduced infiltration rates for NT compared with conventional disk tillage. 


\section{Soil Thermal Properties}

Soil thermal properties can also be affected by tillage practices. Abu-Hamdeh and Reeder (2000) reported that tillage could increase soil bulk density, reduce the spaces between soil particles, reduce volumetric water content and alter soil thermal properties. Ochsner et al. (2001) also reported similar findings. Abu-Hamdeh (2000) reported that for clay loam soils, thermal conductivity ranged from 0.33 to $0.72 \mathrm{~W} \mathrm{~m}^{-1} \mathrm{~K}^{-1}$ in chisel plowed treatments, from 0.30 to $0.48 \mathrm{~W} \mathrm{~m}^{-1} \mathrm{~K}^{-1}$ in rotary plowed treatments, and from 0.45 to 0.78 $\mathrm{W} \mathrm{m}{ }^{-1} \mathrm{~K}^{-1}$ in no-till treatments. Ghauman and Lal (1985) reported similar results. In general, tillage may reduce thermal conductivity by reducing contact between soil minerals, and decrease heat capacity by reducing soil organic carbon over time with tillage and soil water content right after tillage. However, this result of changes in thermal conductivity may be reversed over time due to the probability of increased crusting encouraged by tillage after a few rainfall events.

\section{COVER CROP EFFECTS ON SOIL PHYSICAL AND HYDRAULIC PROPERTIES}

The introduction of cover crops within the crop rotation cycle is a widely used measure to improve soil quality and fertility. Most cover crops are grown in periods when the field is left bare and they can help prime the soil for the corresponding cash crops (Yunusa and Newon, 2003) by influencing soil physical and hydraulic properties.

\section{Soil Bulk Density and Pore Size Distributions}

The influence of cover crops on changes in bulk density and pore size distributions usually results from the roots of the crops. Blanco-Canqui et al. (2011) carried out a 15year study on the effects of including cover crops for enhancing the potential of no-till for 
improving soil physical properties; they found that cover crops had no effect on penetrometer resistance but affected other soil physical properties. Sunn hemp (Crotalaria juncea $\mathrm{L}$.) reduced bulk density by about $4 \%$ compared to no cover crop within the 0-7.5 cm depth.

Bollero et al. (2006) noticed that bulk density significantly increased with depth for all crop sequences, which was in agreement with Blanco-Canqui et al. (2011). However, these increases were more pronounced with the use of winter cover crops than with winter fallowing. While the average increment of bulk density with depth for the fallow treatment was $8.5 \%$, winter cover crop increases in bulk density with depth averaged $15 \%$ (Bollero et al., 2006). This was due to the lower bulk density at the soil surface with cover crops and normal increase in density with depth.

In the study conducted by Bollero et al. (2006), they found that the introduction of winter cover crops decreased bulk density and therefore significantly increased total soil porosity at the soil surface. Changes in pore-size distribution were reflected in significant increases in the volume of transmission pores with the use of the corn-rye/soybean-rye sequence, and the volume of storage pores with the use of any winter cover crop sequences as compared with the corn/soybean sequence. In addition, they (Bollero et al., 2006) reported that a winter cover crop showed a significant reduction of occluded porosity compared with corn/soybean rotation. Bodner et al., (2013), in a study conducted on an arable field in Austria found that the only parameter that was significantly influenced by the soil cover treatment was the pore radius, with cereal rye (Secale cereal L.) having a significantly higher average pore radius compared to no cover crop. They attributed this to the root system of rye being more intense in the top soil compared to mustard roots. 
Bodner et al. (2013) also reported that the only parameter that significantly influenced the pore radius was the soil cover treatment, with rye having a significantly higher average pore radius compared to other treatments. Several researchers (Lal et al., 1991; Villamil et al.; 2006; Haruna and Nkongolo, 2015) have reported higher porosity in cover crop compared to no cover crop management. Williams and Weil (2004) considered cover crops as an effective way to alleviate soil compaction due to root-induced biopores being used by the following crop to penetrate the soil.

\section{Water Content}

The overall effects of cover crops on soil water availability depends largely on the amount of precipitation, water infiltration, evaporation, and transpiration by the cover crops (Unger and Vigil, 1998). Previous studies have shown that cover crops can reduce soil water content, thereby reducing the yield of the subsequent cash crops (Campbell at al., 1984a\&b, Ewing et al., 1991, Keisling et al., 1994). In contrast, Daigh et al. (2014) reported that a cover crop did not significantly affect soil water content even in a dry growing season. In fact, they (Daigh et al., 2014) reported that a cover crop either maintained, or in some cases improved, soil water conservation compared with no cover crop management.

Blanco-Canqui et al., (2011) showed that a cover crop conserved more soil water compared with a no cover crop treatment. These researchers found that cover crops improved the field volumetric water content and buffered soil temperature by acting as a cover, reducing sunlight penetration and water evaporation. Soil water content was greater under cover crops compared to no cover crops by an average of $35 \%$ at the $0-20 \mathrm{~cm}$ depth (Blanco-Canqui et al., 2011). Soil temperature during the day was also consistently lower 
under cover crops than in plots without cover crops. On the average, they (Blanco-Canqui et al., 2011) reported that cover crops reduced the soil temperature during their field measurements in early spring by $4^{\circ} \mathrm{C}$ at the $5 \mathrm{~cm}$ depth, $2^{\circ} \mathrm{C}$ at $15 \mathrm{~cm}$, and $1^{\circ} \mathrm{C}$ lower at 30 $\mathrm{cm}$. As expected, the volumetric water content was highly correlated with soil temperature. Differences in soil temperature explained about $62 \%$ of the variability in water content at the 0-15 cm soil depth (Blanco-Canqui et al., 2011). This result is similar to the findings of Ward et al. (2012) and Blanco-Canqui et al. (2014).

In the same study carried out by Blanco-Canqui et al., (2011), they reported that the addition of cover crops enhanced no-till performance by improving near surface soil physical and hydraulic properties. They also noted that cover crops might ameliorate some risks of excessive near-surface soil compaction and improve soil structure in no-till systems. They (Blanco-Canqui et al., 2011) suggested that cover crops, particularly sunn hemp, might reduce runoff and soil loss by increasing water infiltration. This is consistent with several researchers' findings on the effect cover crops has on soil physical properties (Jokela et al., 2011; Ward et al., 2012; Haruna and Nkongolo, 2015).

\section{Water Infiltration and Saturated Hydraulic Conductivity}

Cover crops can transpire excess water from the field and this can have infiltration benefits. Folorunso et al. (1992) and Joyce et al. (2002) reported improved rainfall infiltration in cover crop plots compared to a fallow rotation. Sunn hemp cover crop has been reported to increase water infiltration rates and cumulative infiltration by three times relative to no-cover crop plots (Blanco-Canqui et al., 2011). These researchers attributed this increase in water infiltration to high earthworm populations enhanced by no-till and cover crops. Kemper and Derpsch (1981) reported that cover crops increased infiltration 
by $416 \%$ on Oxisols and by $629 \%$ on Alfisols compared to no cover crops. They attributed this increase in infiltration rate to the bio-pores formed by the cover crop roots.

Wilson et al. (1982) reported an increase in macro-pores and infiltration with the use of cover crops on an eroded Alfisol in southern Nigeria. McVay et al. (1989) measured infiltration rate on a Coastal plain soil in Georgia using a sprinkler infiltrometer after 3 years of cropping. They reported that the infiltration rate in no-till grain sorghum planted after hairy vetch cover crop averaged about $5.8 \mathrm{~cm} \mathrm{hr}^{-1}$, following a wheat cover crop the infiltration rate was about $4.2 \mathrm{~cm} \mathrm{hr}^{-1}$, and was $3.8 \mathrm{~cm} \mathrm{hr}^{-1}$ following a winter fallow. They also reported that hairy vetch increased infiltration compared with winter fallow in the notill corn system on a Limestone valley soil. Bruce et al., (1992) reported similar findings.

There have been conflicting reports on the effects of cover crops on saturated hydraulic conductivity $\left(K_{s a t}\right)$. For example, Keisling et al., (1990) reported that rye-hairy vetch cover crop sequence increased $K_{\text {sat }}$ by $166 \%$ in the upper $5 \mathrm{~cm}$ of the soil, $194 \%$ in the 5-10 cm depth and 359\% in the 10-15 cm depth compared with no cover crop treatment. However, Wagger and Denton (1989) found no differences in soil porosity and $K_{\text {sat }}$ as a result of wheat and hairy vetch cover crop compared to fallow in a strip tillage system. Carof et al. (2007) and Bodner et al. (2008) did not find a significantly higher hydraulic conductivity under cover crops, but showed a stabilization of near saturated hydraulic properties over time in cover crop compared to no cover crop management.

\section{Soil Thermal Properties}

Because of their potential ability to reduce water evaporation (Blanco-Canqui et al., 2011), increase infiltration (Folorunso et al., 1992; Joyce et al., 2002), increase soil organic matter and aggregation (Dabney et al., 2001) and increase porosity (Williams and Weil, 
2004), cover cops may have an important benefit on thermal properties within the vadoze zone. However, there are currently no studies available to provide valuable information on the effects of cover crops on soil thermal properties. The fifth chapter of this dissertation shows the influence of perennial biofuel and cover crops on soil thermal properties. 


\section{REFERENCES}

Abu-Hamdeh, H.N. 2000. Effect of tillage treatments on soil thermal conductivity for some Jordanian clay loam and loam soils. Soil Tillage Res. 56: 145-151. doi:10.1016/S01671987(00)00129-X.

Abu-Hamdeh, H.N., and R.C. Reeder. 2000. Soil thermal conductivity: Effects of density, moisture, salt concentrations, and organic matter. Soil Sci. Soc. Am. J. 64: 12851290. doi:10.2136/sssaj2000.6441285x.

Alegre, J. C., D.K., Cassel, and E., Amezquita, E. 1991. Tillage systems and soil properties in Latin America. Soil Tillage Res. 20: 147-163.

Alvarez, R., and R.H., Steinbach. 2009. A review of the effects of tillage systems on some soil physical properties, water content, nitrate availability and crops yield in the Argentine Pampas. Soil Tillage Res. 104: 1-15.

Anderson, S.H., C.J., Gantzer, and J.R., Brown. 1990. Soil physical properties after 100 years of continuous cultivation. J Soil Water Conserv. 45: 117-121.

Angers, D.A., V., Poirier, P., Rochette, M.H., Chantigny, N., Ziadi, G., Tremblay, and J., Fortin. 2009. Interactive effects of tillage and mineral fertilization on soil carbon profiles. Soil Sci. Soc. Am. J. 73: 255-261.

Azooz, R. H., and M.A., Arshad. 2001. Soil water drying and recharge rates as affected by tillage under continuous barley and barley-canola cropping systems in northwestern Canada. Can. J. Soil Sci. 81: 45-52.

Balesdent, J., A., Mariotti, and D., Boisgontier. 1990. Effect of tillage on soil organic carbon mineralization estimated from $13 \mathrm{C}$ abundance in maize fields. J. Soil Sci. 41: 587-596.

Beven, K., and P., Germann. 1982. Macropores and water flow in soils. Water Res. Res. 18: 1311-1325.

Bharati, L., K.H. Lee, T.M. Isenhart, and R.C. Schultz. 2002. Soil-water infi ltration under crops, pasture, and established riparian buffer in Midwestern USA. Agrofor. Syst. 56: 249-257.

Blanco-Canqui, H., R.B., Ferguson, V.L., Jin, M.R., Schmer, B.J., Wienhold, and J., Tatarko. 2014. Can cover crop and manure maintain soil properties after stover removal from irrigated no-till corn? Soil Sci. Soc. Am. J. 78: 1368-1377.

Blanco-Canqui, H., M.M. Mikha, D.R. Presley, and M.M., Claassen. 2011. Addition of cover crops enhances no-till potential for improving soil physical properties. Soil Sci. Soc. Am. J. 75: 1471-1478. doi:10.2136/sssaj2010.0430. 
Blanco-Canqui, H. 2010. Energy crops and their implications on soil and environment. Agron. J. 102: 403-419. doi:10.2134/agronj2009.0333.

Bodner, G., W., Loiskandl, G., Buchan, and H.P., Kaul. 2008. Natural and management induced dynamics of hydraulic conductivity along a cover-cropped field slope. Geoderma. 146: 317-325.

Bodner, G., P., Scholl, W., Loiskandl, and H.P., Kaul. 2013. Environmental and management influences on temporal variability of near saturated soil hydraulic properties. Geoderma. 204: 120-129.

Bollero, G.A., M.B., Villamil, R.G., Darmody, F.W., Simmons, and D.G., Bullock. 2006. No-till corn/soybean systems including winter cover crops: Effects on soil properties. Soil Sci. Soc. Am. J. 70: 1936-1944.

Brandt, S. A. 1992. Zero vs. conventional tillage and their effects on crop yield and soil moisture.Can. J. Pl. Sci. 72: 679-688.

Bristow, K.L. 2002. Thermal conductivity. In: J.H. Dane and G.C. Topp, editors, Methods of soil analysis. Part 4. SSSA Book Ser. 5. SSSA, Madison, WI. p. 1209-1226. doi:10.2136/sssabookser5.4.c50.

Bronick, C.J., and R., Lal. 2005. Soil Structure and management: a review. Geoderma. 124: 3-22.

Bruce, R.R., G.W. Langdale, L.T. West, and W.P. Miller. 1992. Soil surface modification by biomass inputs affecting rainfall infiltration. Soil Sci. Soc. Am. J. 56:16141620 .

Campbell, R.B., D.L. Karlen, and R.E. Sojka. 1984a. Conservation tillage for maize production in the U.S southern coastal plain. Soil Tillage Res. 4:511-529.

Campbell, R.B., R.E. Sojka, and D.L. Karlen. 1984b. Conservation tillage for soybean production in the U.S southern coastal plain. Soil Tillage Res. 4:531-541.

Carof, M., S., De Tourdonnet, Y., Coquet, V., Hallaire, and J., Roger-Estrade. 2007. Hydraulic conductivity and porosity under conventional and no-tillage and the effect of three species of cover crop in northern France. Soil Use Mgt. 23: 230 237.

Carter, M. R., and G.R., Steed. 1992. The effects of direct drilling and stubble retention on hydraulic properties at the surface of duplex soils in north-eastern Victoria. Soil Res. 30: 505-516. 
Chang, C., and C.W., Lindwall. 1989. Effect of long-term minimum tillage practices on some physical properties of a Chernozemic clay loam. Can. J. Soil Sci. 69: 443449.

Chang, C., and C.W., Lindwall. 1990. Comparison of the effect of long term tillage and crop rotation on physical properties of a soil. Can. J. Soil Sci. 32: 53-55.

Chang, C., and C.W., Lindwall. 1992. Effects of tillage and crop rotation on physical properties of a loam soil. Soil Tillage Res. 22: 383-389.

Chatskikh, D., S., Hansen, J.E., Olesen, and B.M., Petersen. 2009. A simplified modeling approach for quantifying tillage effects on carbon stocks. Eur. J. Soil Sci. 60: 924-934.

Christopher, S.F., and R.L.U., Mishra. 2009. Regional study of no-till effects on carbon sequestration in the Midwestern United States. Soil Sci. Soc. Am. J. 73: 207216.

Conant, R.T., M., Easter, K., Paustian, S., Swan, and S., Williams. 2007. Impacts of periodic tillage on soil carbon stocks: A synthesis. Soil Tillage Res. 95: 1-10.

Craine, J.M., A.J. Elmore, K.C. Olson, and D. Tollenson. 2010. Climate change and cattle nutritional stress. Glob. Change Biol. 16: 2901-2911. doi:10.1111/j.13652486.2009.02060.x

D’Haene, K., J., Vermang, W.M., Cornelis, B.L., Leroy, W., Schiettecatte, S., De Neve, D., Gabriels, and G., Hofman. 2008. Reduced tillage effects on physical properties of silt loam soils growing root crops. Soil Tillage Res. 99: 279-290.

Dabney, S.M., J.A. Delgado, and D.W. Reeves. 2001. Using winter cover crops to improve soil and water quality. Commun. Soil Sci. Plant Anal. 32: 1221-1250. doi:10.1081/CSS-100104110.

Daigh, A.L., M.J., Helmers, E., Kladivko, X., Zhou, R., Goeken, J., Cavdini, D., Barker, and J., Sawyer. 2014. Soil water during the drought of 2012 as affected by rye cover crops in fields in Iowa and Indiana. J. Soil Water Conserv. 69: 564-573.

Deb, S.K., M.K., Shukla, and J.G. Mexal. 2011. Numerical modelling of water fluxes in the root zone of a mature pecan orchard. Soil Sci. Soc. Am. J. 75: 1667-1680.

Defossez, P., J.O., Pereira, and G., Richard. 2007. Soil susceptibility to compaction by wheeling as a function of some properties of a silty soil as affected by the tillage system. Eur. J. Soil Sci. 58: 34-44. 
de Vries, D.A. 1975. Heat transfer in soils. In D. A. de Vries and N. H. Afgan (eds.) Heat and mass transfer in biosphere. Scripta book company, Washington, DC, pp. 528.

Elder, J. W., and R., Lal. 2008. Tillage effects on physical properties of agricultural organic soils of north central Ohio. Soil Tillage Res. 98: 208-210.

Eltaif, N. I., M.A., Gharaibeh, and Z.A., Ababneh. 2011. Changes in selected soil physical properties caused by sodicity of soil and irrigation water. Acta Agric. Scand. Section B-Soil Pl. Sci. 61: 84-91.

Ewing, R.P., M.G. Wagger, and H.P. Denton (1991). Tillage and cover crop management effects on soil water and corn yield. Soil Sci. Soc. Am. J. 55: 1081-1085.

Fisk, J.W., O.B., Hesterman, A., Shrestha, J.J., Kells, R.R., Harwood, J.M., Squire, and C.C., Sheaffer. 2001. Weed suppression by annual legume cover crops in notillage corn. Agron. J. 93: 319-325.

Folorunso, O.A., D.E., Rolston, T., Prichard, and D.T., Loui. 1992. Soil surface strength and infiltration as affected by winter cover crops. Soil Tech. 5: 189-197.

Franzluebbers, A. J., F., Magdoff, and R.W., Ray. 2004. Tillage and residue management effects on soil organic matter. Soil Org. Matter Sust. Ag. 1: 227-268.

Ghauman, B.S., and R. Lal. 1985. Thermal conductivity, thermal diffusivity, and thermal capacity of some Nigerian soils. Soil Sci. 139: 74-80.

Gimenez, D., E., Perfect, W.J., Rawls, and Y., Pachepsky. 1997. Fractal models for predicting soil hydraulic properties: a review. Eng. Geol. 48: 161-183.

Håkansson, I. 1990. A method for characterizing the state of compactness of the plough layer. Soil Tillage Res. 16: 105-120.

Hamza, M.A., and W.K., Anderson. 2005. Soil compaction in cropping systems. A review of the nature, cause and possible solutions. Soil Tillage Res. 82: 121145.

Haruna, S. I., and N.V., Nkongolo. 2015. Effects of tillage, rotation and cover crop on the physical properties of a silt-loam soil. Intern. Agrophysics. 29: 137-145.

Heuscher, S.A., C.C., Brandt, and P.M., Jardine. 2005. Using soil physical and chemical properties to estimate bulk density. Soil Sci. Soc. Am. J. 69: 51-56.

Horne, D. J., Ross, C. W., and K. A., Hughes. 1992. Ten years of a maize/oats rotation under three tillage systems on a silt loam in New Zealand. 1. A comparison of some soil properties. Soil Tillage Res. 22: 131-143. 
Jiang P., S.H., Anderson, N.R., Kitchen, E.J., Sadler, and K.A., Sudduth. 2007. Lanscape and conservation management effects on hydraulic properties of a claypan soil toposequence. Soil Sci. Soc. Am. J. 71: 803-811.

Jokela, W., J., Posner, J., Hedtcke, T., Balser, and H., Read. 2011. Midwest cropping system effects on soil properties and on a soil quality index. Am. Soc. of Agron. J. 103: $1552-1562$.

Joyce, B.A., W. W., Wallender, J.P., Mitchell, L.M., Huyck, S.R., Temple, P.N., Brostrom, and T.C., Hsiao. 2002. Infiltration and soil water storage under winter cover cropping in California's Sacramento Valley. Transactions of ASAE 45: 315-326.

Juarez, M., J., Sanchez, and A., Sanchez. 2006. Quimica del suelo y medio ambiente. Publicaciones de la Universidad de Alicante, Alicante, Spain.

Juhasz, C.E.P., M., Cooper, P., Ribeiro, A., Oppitz, and R., Shiso. 2007. Savanna woodland soil micromorphology related to water retention. Scientia Agricola 64: 344-354.

Kasper, T.C., and J.W. Singer. 2011. The use of cover crops to manage soil. In Hartfield J.L and T.J. Sauer (eds.) Soil management: Building a stable base for agriculture. Pp 321-337. ASA, SSSA, Madison, WI.

Katsvairo, T.W., D.L., Wright, J.J., Marois, D.L., Hartzog, K.B., Balkcom, P.P., Wiatrak, and J.R., Rich. 2007. Cotton roots, earthworms, and infiltration characteristics in sod-peanut-cotton cropping systems. Agron. J. 99: 390-398.

Keller T. and I. Håkansson. 2010. Estimation of reference bulk density from soil particle size distribution and soil organic matter content. Geoderma 154: 398-406.

Kemper, B. and R. Derpsch. 1981. Results of studies made in 1978 and 1979 to control erosion by cover crops and no-tillage techniques in Parana, Brazil. Soil Tillage Res. 1:253-267.

Kiehl, J. T., and K.E., Trenberth. 1997. Earth's annual global mean energy budget. Bull. Am. Met. Soc. 78: 197-208.

Keisling, T.C., H.D. Scott, B.A. Waddle, W. Williams, and R.E. Frans. (1994). Winter cover crop influence on cotton yield and selected soil properties. Comm. Soil Sci. \& Pl. Analy. 25: 3087-3100.

Kironchi, G., S.M., Kinyali, and J.P., Mbuvi. 1995. Environmental influence on water characteristics of soils in two semi-arid catchments in Laikipia, Kenya. Afr. Crop Sci. J. 3: 479-486. 
Koch, H.J. and N., Stockfisch. 2006. Loss of soil organic matter upon ploughing under a loess soil after several years of conservation tillage. Soil Tillage Res. 86: 73-83.

Kumar S., S.H., Anderson, L.G., Bicknell, R.P., Udawatta, and C.J., Gantzer. 2008. Soil hydraulic properties influenced by agroforestry and grass buffers for grazed pasture systems. J. Soil Water Conserv. 63: 224-232.

Lal, R., E., Regnier, D.J., Eckert, W.M., Edwards, and R., Hammond. 1991. Expectations of cover crops for sustainable agriculture. In Hargrove W L, (ed.) Cover crops for clean water. Soil and Water Society. Ankeny, Iowa. pp 1-11.

Lal, R. 1997. Residue management, conservation tillage and soil restoration for mitigating greenhouse effect by CO 2-enrichment. Soil Tillage Res. 43: 81-107.

Lin, H.S., K.J., McInnes, L.P., Wilding, and C.T., Hallmark. 1996. Effective porosity and flow rate with infiltration at low tensions in a well-structured subsoil. Trans. ASAE 39: 131-133.

Logsdon, S.D., and D.B., Jaynes. 1996. Spatial variability of hydraulic conductivity in a cultivated field at different times. Soil Sci. Soc. Am. J. 60: 703-709.

Logsdon, S.D., J.L., Jordahl, and D.L., Karlen. 1993. Tillage and crop effects on ponded and tension infiltration rates. Soil Tillage Res. 28: 179-189.

Lu, Y.C., K.B. Watkins, J.R. Teasdale, and A.A. Abdul-Baki. 2000. Cover Crops in Sustainable Food Production. Food Rev. Int. 16: 121-157.

Lupwayi, N.Z., M.A., Arshad, W.A., Rice, and G.W., Clayton. 2001. Bacterial diversity in water stable aggregates of soils under conventional and zero tillage management. Appl. Soil Ecol. 16: 251-261.

Luxmoore, R.J., P.M., Jardine, G.V., Wilson, J.R., Jones, and L.W., Zelazny. 1990. Physical and chemical controls of preferred path flow through a forested hillslope. Geoderma. 46: 139-154.

MacRae, R.J., and G.R. Mehuys. 1985. The effect of green manuring on the physical properties of temperate-area soils. p. 71-94. In Stewart, B.A. (ed.), Advances in Soil Science. Advances in Soil Science. Springer New York.

Mahboubi, A. A., R., Lal, and N.R., Faussey. 1993. Twenty-eight years of tillage effects on two soils in Ohio. Soil Sci. Soc. Am. J. 57: 506-512. 
Malhi, S. S., R., Lemke, Z.H., Wang, and B.S., Chhabra. 2006. Tillage, nitrogen and crop residue effects on crop yield, nutrient uptake, soil quality, and greenhouse gas emissions. Soil Tillage Res. 90: 171-183.

McLaughlin, N.B., C.F., Drury, W.D., Reynolds, X.M., Yang, Y.X., Li, T.W., Welacky, and G., Stewart. 2008. Energy inputs for conservation and conventional primary tillage implements in a clay loam soil. Transactions of the ASABE. 51: 1153-1163.

McVay, K.A., D.E. Radcliffe, and W.L. Hargrove. 1989. Winter legume effects on soil properties and nitrogen fertilizer requirements. Soil Sci. Soc. Am. J. 53:18561862.

Messing, I., and N.J., Jarvis. 1993. Temporal variation in the hydraulic conductivity of a tilled clay soil as measured by tension infiltrometers. J. Soil Sci. 44: 11-24.

Möller, K., W., Stinner, and G., Leithold. 2008. Growth, composition, biological N2 fixation and nutrient uptake of a leguminous cover crop mixture and the effect of their removal on field nitrogen balances and nitrate leaching risk. Nutr. Cycl. Agroecosyst. 82: 233-249.

Nemes, A., B., Quebedeaux, and D.J., Timlin. 2010. Ensemble approach to provide uncertainty estimates of soil bulk density. Soil Sci. Soc. Am. J. 74: 1938-1945.

Nimmo, J.R. 1997. Modeling structural influences on soil water retention. Soil Sci. Soc. Am. J. 61: 712-719.

Nyakatawa, E.Z., K.C., Reddy, and J.L., Lemunyon. 2001. Predicting soil erosion in conservation tillage cotton production systems using the revised universal soil loss equation (RUSLE). Soil Tillage Res. 57: 213-224.

Ochsner, T.E., E.S., Krueger, and A.M., Liesch. 2011. Soil structure and physical properties under rye-corn silage double-cropping systems. Soil Sci. Soc. Am. J. 75: 1307-1314.

Ochsner, T.E., R. Horton, and T. Ren. 2001. A new perspective on soil thermal properties. Soil Sci. Soc. Am. J. 65:1641-1647. doi:10.2136/sssaj2001.1641.

Pachepski, Y., and W., Rawls. 2003. Soil structure and pedotransfer functions. Eur. J. Soil Sci. 54: 443-451.

Pereira, H. C. 1975. Agricultural science and the traditions of tillage. Outlook on Agriculture (UK).

Perez-de-los-Reyes, C., J.A., Ortiz-Villajos, F.J.G., Navarro, S. B., Martin-Consuegra, C. S., Jimenez, D.C., Eteson, and R., Jimenez-Ballesta. 2011. Changes in water 
retention properties due to the application of sugar foam in red soils. Agri. Water Mgt. 98: 1834- 1839.

Pieters, A.J. 1927. Green manuring principles and practice. New York: John Wiley and Sons.

Pimentel, D., C., Harvey, P., Resosudarmo, K., Sinclair, D., Kurz, M., McNair, S., Crist, L., Sphritz, L., Fitton, R., Saffouri, and R., Blair. 1995. Environmental and economic costs of soil erosion and conservation benefits. Science. 276: 11171123.

Poesse, G. J. 1992. Soil compaction and new traffic systems. Possibilities offered by new mechanization systems to reduce agricultural production costs. The Netherlands, 79-91.

Rachman, A., S.H., Anderson, C.J., Gantzer, and E.E., Alberts. 2004. Soil hydraulic properties influenced by stiff-stemmed grass hedge systems. Soil Sci. Soc. Am. J. 68:1386-1393.

Raczkowski, C.W., J.P., Mueller, W.J., Busscher, M.C., Bell, and M.L., McGraw. 2012. Soil physical properties of agricultural systems in a large-scale study. Soil Tillage Res. 119: 50-59.

Raper, R.L. and J.S., Bergtold. 2007. In-row subsoiling: a review and suggestions for reducing cost of this conservation tillage operation. Applied Engineering in Agricult. 23: 463-471.

Reeves, D. W. 1994. Cover crops and rotations. Adv. Soil Sci: Crop Residue Mgt. 125172.

Reichert, J.M., L.E.A.S., Suzuki, D.J., Reinert, R., Horn, and I., Håkansson. 2009. Reference bulk density and critical degree-of-compactness for no-till crop production in subtropical highly weathered soils. Soil Tillage Res. 102: 242-254.

Ross, C. W., and K.A., Hughes. 1985. Maize/oats forage rotation under 3 cultivation systems, 1978-83: 2. Soil properties. New Zealand J. Agri. Res. 28: 209-219.

Scanlon, B. R., R.C., Reedy, D.A., Stonestrom, D.E., Prudic, and K.F., Dennehy. 2005. Impact of land use and land cover change on groundwater recharge and quality in the southwestern US. Global Change Biol.11: 1577-1593.

Schwen, A., G., Bodner, P., Scholl, G.D., Buchan, and W., Loiskand. 2011. Temporal dynamics of soil hydraulic properties and the water-conducting porosity under different tillage. Soil Tillage Res. 113: 89-98. 
Seobi, T., S.H., Anderson, R.P., Udawatta, and C.J., Gantzer. 2005. Influence of grass and agroforestry buffer strips on soil hydraulic properties for an Albaqualf. Soil Sci. Soc. Am. J. 69: 893-901.

Sharma, S.N., R., Prasad, M.K., Dwivedi, S., Kumar, M.R., Davari, and M., Ram. 2009. Effects of cropping system on production and chemical and biological properties of soil. Archives Agron. Soil Sci. 55: 429-438.

Shi, X.H., X.M., Yang, C.F., Drury, W.D., Reynolds, N.B., McLaughlin, and X.P., Zhang. 2012. Impact of ridge tillage on soil organic carbon and selected physical properties of a clay loam in southwestern Ontario. Soil Tillage Res. 120: $1-7$.

Shipitalo, M.J., and W.M., Edwards. 1996. Effects of initial water content macropore/matrix flow and transport of surface-applied chemicals. J. Environ. Qual. 25: 662-670.

Shukla, M. K. 2014. Soil physics: An introduction. CRC Press.

Shukla, M.K., R., Lal, L.B., Owens, and P., Unkefer. 2003. Land use and management impacts on structure and infiltration characteristics of soils in the North Appalachian region of Ohio. Soil Sci. 168: 167-177.

Shukla, M.K., and R., Lal. 2005. Erosional effects on soil properties in an on-farm study on Alfisol in west central Ohio. Soil Sci. 170: 445-456.

Simon, T., M., Juvurek, O., Mikanova, and M., Vach. 2009. The influence of tillage systems on soil organic matter and soil hydrophobicity. Soil Tillage Res. 105: 44-48.

SSSA, 2008. Glossary of Soil Science Terms. SSSA, Madison, WI. , www.soils.org/ publications/soils-glossary.

Strudley, M.W., T.R., Green, and J.C., Ascough. 2008. Tillage effects on soil hydraulic properties in space and time: State of the science. Soil Tillage Res. 99: 4-48.

Umiker, K.J., J.L., Johnson-Maynard, T.D., Hatten, and S.D., Eigenbrode. 2009. Soil carbon, nitrogen, $\mathrm{pH}$, and earthworm density as influenced by cropping practices in the inland Pacific Northwest. Soil Tillage Res. 105: 184-191.

Unger, P.W, and M.F Vigil 1998. Cover crop effects on soil water relationships. J. Soil Water Cons. 53:200 - 207.

Villamil, M.B., G.A., Bollero, R.G., Darmody, F.W., Simmons, and G.G., Bullock. 2006. No-till corn/soybean systems including winter cover crops. Soil Sci Soc Am J. 70: 1936-1944. 
Wagger, M.G. and H.P. Denton. 1989. Influence of cover crop and wheel traffic on soil physical properties in continuous no-till com. Soil Sci. Soc. Am. J. 53:1206-1210.

Walczak, R.T., F., Moreno, C., Sławin' ski, E., Fernandez, and J.L., Arrue. 2006. Modeling of soil water retention curve using soil solid phase parameters. J. Hydrol. 329: 527-533.

Ward, P. R., K.C., Flower, N., Cordingley, C., Weeks, and S.F., Micin. 2012. Soil water balance with cover crops and conservation agriculture in a Mediterranean climate. Field Crops Res. 132: 33-39.

Western, A.W., R.B., Grayson, G., Blo“ schl, and D.J., Wilson. 2003. Spatial variability of soil moisture and its implication for scaling. In: Pachepsky, Y., Radcliffe, D.E., Selim, H.M. (Eds.), Scaling Methods in Soil Physics. CRC Press, Boca Raton, USA, pp. 119-142.

Williams, J., R. E., Prebble, W.T., Williams, and C.T., Hignett. 1983. The influence of texture, structure and clay mineralogy on the soil moisture characteristic. Austr. J. Soil Res. 21: 15-32.

Williams, S.M., and R.R., Weil. 2004. Crop cover roots may alleviate of soil compaction effects on soybean crop. Soil Sci. Soc. Am. J. 68: 1403-1409.

Wilson, G. F., R. Lal, and B. N. Okigbo. 1982. Effects of cover crops on soil structure and on yield of subsequent arable crops grown under strip tillage on an eroded Alfisol. Soil Tillage Res. 2: 233-250.

Wosten, J.H.M., Y.A., Pachepsky, and W.J., Rawls. 2001. Pedotransfer functions: bridging the gap between available basic soil data and missing soil hydraulic characteristics. J.Hydrol. 251: 123-150.

Wyland, L.J., L.E. Jackson, W.E. Chaney, K. Klonsky, S.T. Koike, and B. Kimple. 1996. Winter cover crops in a vegetable cropping system: Impacts on nitrate leaching, soil water, crop yield, pests and management costs. Agric. Ecosyst. Environ. 59: $1-17$.

Yunusa, I.A.M., and P.J. Newton. 2003. Plants for amelioration of subsoil constraints and hydrological control: the primer-plant concept. Plant Soil 257: 261-281.

Zhang, J.H., Z.A., Su, and X.J., Nie. 2009. An investigation of soil translocation and erosion by conservation hoeing tillage on steep lands using a magnetic tracer. Soil and Tillage Res. 105: 177-183. 
Zhang, X., Q., Li, A., Zhu, W., Liang, J., Zhang, and Y., Steinberger. 2012. Effects of tillage and residue management on soil nematode communities in North China. Ecol. Indicators. 13: 75-81. 


\title{
CHAPTER 3
}

\section{SOIL HYDRAULIC PROPERTIES: INFLUENCE OF TILLAGE AND COVER CROPS}

\begin{abstract}
Understanding the effects of cover crops and tillage on soil physical properties is important for determining soil productivity. This study was conducted at Lincoln University's Freeman Center to evaluate the effects of tillage and cover crop management on soil hydraulic properties. The field site included three replicate blocks in a randomized complete block design with each plot measuring $21.3 \mathrm{~m}$ length and $12.2 \mathrm{~m}$ width. Treatment factors were tillage at two levels (moldboard plow tillage vs. no till) and cover crop at two levels (cereal rye [Secale cereal L.] cover crop vs. no cover crop). Soil samples were collected in late spring/early summer from each treatment in $10 \mathrm{~cm}$ depth increments from the soil surface to a depth of $40 \mathrm{~cm}$ using $76.2 \mathrm{~mm}$ diameter $\mathrm{x} 76.2 \mathrm{~mm}$ long cores. Soil bulk density values for tillage were $13 \%$ lower compared with no-till management. Water content was significantly higher at the 0.0 and $-0.4 \mathrm{kPa}$ pressures for the tillage compared with no-till management. Tillage improved coarse mesopores by $32 \%$ compared with no-till and this resulted in $87 \%$ higher saturated hydraulic conductivity values. Cover crops improved macropores by $24 \%$ compared with no cover crop; this can potentially increase water infiltration and reduce runoff. As a result of higher macroporosity, saturated hydraulic conductivity was higher in the cover crop compared with no cover crop management. This study demonstrated that tillage can benefit soil hydraulic properties in the short term but these effects may not persist over time. Cover crops may slightly improve soil hydraulic properties but longer term studies are needed to evaluate its long term effects.
\end{abstract}


Key Words: pore size distribution, saturated hydraulic conductivity, soil bulk density, soil water retention. 


\section{INTRODUCTION}

Increased water infiltration and retention in the soil, especially within the vadoze zone, are important factors that determine crop productivity and soil loss. These processes are especially important in less developed regions of the world where most producers have little or no access to irrigation. Soil water is important for nutrient availability and transport (Sparling and West, 1989) and microbial activity (Sylvia et al., 2005). Agricultural land management practices can influence soil structure and they may have a direct or indirect effect on soil hydraulic properties. One of those management practices is tillage.

Tillage involves seedbed preparation through mechanical agitation by digging, stirring and overturning the soil (Conant et al., 2007). Tillage has been used to prepare seedbeds, incorporate fertilizers, manures and residues into the soil, and to control weeds (Leij et al., 2002). However, tillage can be destructive and lead to soil and nutrient loss, soil moisture loss and overall degradation of soils (Ogle et al., 2003). One way to assess the effects of tillage on soil structure is to evaluate hydraulic properties. Hydraulic properties that are agronomically important include, but are not limited to, soil bulk density, soil water retention, pore size distribution (Haverkamp et al., 2005; Walczak et al., 2006; Shukla, 2014) and saturated hydraulic conductivity ( $\mathrm{K}_{\text {sat }}$ ) (Logsdon and Jaynes, 1996; Prieksat et al., 1994). These properties may show a temporal variability that depends on different interrelated factors, including soil stability, climate, land use, dynamics of plant canopy and roots, and various soil management operations (Prieksat et al., 1994).

In their 10 year study of no-till with winter wheat on a silt loam soil in Canada, Chang and Lindwall (1992) observed lower water holding capacity in the 3-6 cm depth interval due to tillage despite no noticeable tillage effects above or below this zone. 
However, in a 12 year study of no-till (NT) vs conventional tillage (CT), Brandt (1992), found that no-till resulted in greater soil water content in 9 out of the 36 sites studied and no significant differences in the rest. This was due to biopores developed by soil microorganisms due to less soil disturbance. Water retention at 6 matric potentials, from 5 to $-160 \mathrm{kPa}$, was measured by Azooz and Arshad (2001). They found higher water retention in no-till compared with conventional tillage. They also reported that the rate of soil drying in the top $30 \mathrm{~cm}$ was greater for CT compared with NT, while the rate of wetting was greater in the NT. Because tillage can increase soil pore tortuosity, Benjamin (1993) reported that NT improved saturated hydraulic conductivity by 30 to $180 \%$ compared with moldboard plow and chisel plow. Other researchers (e.g Azooz and Arshad, 1996; Osunbitan et al., 2005) have reported similar findings. However, Heard et al. (1988) reported contrasting results with saturated hydraulic conductivities of their treatments in the following order: moldboard plow $>$ chisel plow $>$ ridge till $>$ no-till.

Besides tillage management, producers and farm managers also implement cover crops under favorable climatic and financial conditions for various reasons. Cover crops are crops grown for their ability to condition the soil and protect it from erosion, especially during periods when the soil is left bare (Troeh et al., 2004). Cover crops have been reported to reduce soil bulk density (Blanco-Canqui et al., 2011) and increase soil macroporosity (Villamil et al., 2006).

Auler et al. (2014) reported that annual ryegrass (Lolium multflorum L.) used as a cover crop reduced soil bulk density and microporosity and increased macroporosity and total porosity which can lead to better water flow in the soil. They also reported that water retention was higher in the top $10 \mathrm{~cm}$ of the soil when ryegrass was planted in combination 
with CT, minimum tillage (MT) and chisel tillage. In their study of the effects of tillage systems and cover crops on soil quality, Abdollahi et al. (2014) reported that the use of a cover crop increased air-filled porosity at $-10 \mathrm{kPa}$, air permeability, and pore organization and reduced the value of blocked air porosity at all depths for all tillage treatments.

In Arkansas, Keisling et al. (1990) reported that ryegrass - hairy vetch (Vicia villosa L.) cover crop sequence improved the $\mathrm{K}_{\text {sat }}$ of the top $5 \mathrm{~cm}$ of the soil by $166 \%$, by $194 \%$ in the 5-10 cm depth and by $359 \%$ in the $10-15 \mathrm{~cm}$ depth compared with no cover crop treatment. However, Wagger and Denton (1989) found no differences in soil porosity and $\mathrm{K}_{\text {sat }}$ as a result of wheat (Triticum $\mathrm{L}$.) and hairy vetch cover crop compared to fallow in a strip tillage system.

The ambiguities in these findings suggests that more studies need to be conducted to improve our understanding on how tillage, cover crops and the interactions between these management practices affect soil hydraulic properties. Such studies would be very beneficial in agriculturally important regions such as the Midwestern United States. We hypothesize that tillage and cover crop may significantly affect soil hydraulic properties in the short term. The specific objective of this study was to assess the influence of tillage and cover crops on soil hydraulic properties. These properties included soil bulk density, soil water retention, pore size distribution and saturated hydraulic conductivity.

\section{MATERIALS AND METHODS}

\section{Site description}

The study area, Lincoln University's Freeman Center, is located about $8 \mathrm{~km}$ northeast of Jefferson City, Missouri, USA. The soil is classified by the United States 
Department of Agriculture (USDA) as a Waldron silt-loam (fine, smectitic, calcareous, mesic Aeric Fluvaquents). Table 3.1 shows selected soil physical and chemical properties of the soil. The study site lies at an elevation of about $166 \mathrm{~m}$ above sea level with a $2 \%$ slope. It was in a $50 \mathrm{yr}$ corn (Zea mays L.) and soybean (Glycine max L.) rotation with moldboard plow prior to the establishment of this research in 2010. This study was carried out four years after the establishment of this research. For this study, the field was set up using a randomized complete block design with treatments that included tillage (moldboard plow) at two levels (tillage vs no tillage) and cereal rye cover crop (Secale cereal L.) at two levels (cover crop vs no cover crop), with three replicates. The main crop grown on the field site was corn planted in late April or early May, depending on weather variability, and harvested in September or October of each growing season. The cover crop was planted after harvesting the main crop each year. The cover crop was allowed to grow during winter and spring months and terminated in April using glyphosate ( $N$-[phosphonomethyl] glycine) prior to tillage and planting of the main crop. The soil was tilled to a depth of 15 $\mathrm{cm}$. This was done in late April or early May of each growing season. Further details about the site and the experimental design are given in Haruna and Nkongolo (2015).

\section{Soil sampling}

Soil samples were collected using a sampler with a cylindrical core measuring 76.2 mm diameter by $76.2 \mathrm{~mm}$ long (Uhland, 1942). The samples were collected two weeks after cover crop termination (just after tillage), in the third week of May, 2014, at four depths of $10 \mathrm{~cm}$ increments from the soil surface to a depth of $40 \mathrm{~cm}$ (Kladivko et al., 2014). During soil sample collection, the cores were taken at the middle of each depth. For example, at the $10-20 \mathrm{~cm}$ depth, the soil samples were collected from 11 to $18.6 \mathrm{~cm}$ depth. 
Thus, the plow pan transition zone lies between 15 to $17.5 \mathrm{~cm}$ within the sample cylinder (before and after plowing). The specific treatments included cover crop with tillage (CCTill), cover crop with no till (CC-NT), no cover crop with tillage (NC-Till) and no cover crop with no till (NC-NT). Two samples (sub-samples) were collected at each depth in all treatments ( 4 treatments $\times 4$ depths $x 2$ sub-samples $\times 3$ replicates $=96$ cores ).

Soil samples were also collected one week before the cover crop termination from each of the aforementioned treatments and replicates from two depths only, 0-10 and 10$20 \mathrm{~cm}$ ( 4 treatments $\mathrm{x} 2$ depths $\times 3$ replicates $=24$ cores $)$. This additional sampling was done to better demonstrate and understand the immediate influence of tillage and the annual benefits of cover crops on soil hydraulic properties. These samples also represent field conditions approximately one growing season after the previous tillage and was done for a temporal comparison of tillage effects on soil properties. Each plot measured $21.3 \mathrm{~m}$ length and $12.2 \mathrm{~m}$ width. All soil samples were stored in a cold storage room at $4^{\circ} \mathrm{C}$ until analysis was done.

\section{Sample preparation and analysis}

For saturated hydraulic conductivity measurements, cheesecloth was attached to the bottom of the soil core using rubber bands and another empty core was attached to the top of the core. Soils were saturated for about 48 hours in a tub by gently raising the water level. The electrical conductivity of the water was $0.68 \mathrm{dS} \mathrm{m}^{-1}$ and the sodium absorption ratio was 2.34 . To reduce preferential flow along the core wall, a mixture of bentonite and water in a ratio of 1:8 was added to the core edge. The constant head method was used to evaluate saturated hydraulic conductivity $\left(\mathrm{K}_{\mathrm{sat}}\right)$ (Reynolds and Elrick, 2002). For soils with $\mathrm{K}_{\text {sat }}$ values less than $0.1 \mathrm{~cm} \mathrm{hr}^{-1}$, the falling head method was used. 
Using the same cores, water retention was then measured immediately after $\mathrm{K}_{\mathrm{sat}}$ measurement at $0.0,-0.4,-1.0,-2.5,-5.0,-10$, and $-20 \mathrm{kPa}$ pressures using compressed air and ceramic plates. The samples were air dried at $35^{\circ} \mathrm{C}$ for $120 \mathrm{hrs}$, removed from the sampling cylinder and split into two halves: one half was used for obtaining soil aggregates while the other half was ground and passed through a $2 \mathrm{~mm}$ sieve. The aggregate sample was used with pressure plates for -33 and $-100 \mathrm{kPa}$ pressures. The $<2 \mathrm{~mm}$ samples were used with pressure plates at $-1500 \mathrm{kPa}$ pressure (Dane and Hopmans, 2002). The soil bulk density was determined using the air-dried weight adjusted for oven dry weight with a measured water content.

Pore size distributions were calculated using the capillary rise equation to estimate effective pore size classes (Jury et al., 1991) from the water retention data. Four classes of pore sizes were used: macropores $(>1,000 \mu \mathrm{m}$ effective diameter), coarse mesopores (60 to $1,000 \mu \mathrm{m}$ effective diameter), fine mesopores (10 to $60 \mu \mathrm{m}$ effective diameter) and micropores (<10 $\mu \mathrm{m}$ effective diameter) (Anderson et al., 1990).

\section{Statistical analysis}

A test of variance homogeneity within the different treatments was conducted to evaluate the variability in the measurements. Analysis of variance (ANOVA) was conducted using SAS statistical software (SAS institute 2013) using the general linear model (GLM) procedure. Single degree of freedom contrasts for the treatment (tillage and cover crop) effects were divided into 'tillage vs. no-till', 'cover crop vs. no cover crop' and 'tillage $\mathrm{x}$ cover crop' interaction. Statistical differences are declared to exist at $\alpha \leq 0.05$ level. 


\section{RESULTS AND DISCUSSION}

\section{Bulk density}

Bulk density results for the main sampling (two weeks after spring tillage and cover crop termination; four depths, $0-10,10-20,20-30$ and 30-40 cm) are shown in Table 3.2 and Figure 3.1a. Results show a significant treatment by depth (treatment $\mathrm{x}$ depth) interaction for soil bulk density $(\mathrm{p}<0.01)$. Bulk density was $13 \%$ lower when the soil was tilled compared with no tillage in the $0-10 \mathrm{~cm}$ depth (Fig. 3.1a). As expected, bulk density was lowest in the $0-10 \mathrm{~cm}$ depth of the tilled treatments compared to the no-till treatments but no differences occurred at the 10-20 cm depth (Fig. 3.1a). Since soil samples were collected right after tillage, it is presumed that this lower bulk density results from the fact that tillage can temporarily relieve soil compaction. This may be beneficial in soils compacted by equipment, human and animal traffic like new farms converted from previous forests and the edges of some farms. Several researchers (e.g Lampurlanes and Cantero-Martinez, 2003; Osunbitan et al., 2005; Dam et al., 2005) have reported similar findings.

Averaged across soil depth, soil bulk density was not significantly affected by cover crop or tillage. However, tillage had numerically lower soil bulk density values compared to no-till (Table 3.2). Bulk density was significantly lower in the $0-10 \mathrm{~cm}$ depth and highest in the 10-20 cm depth (Table 3.2). One possible reason for this high bulk density in the 10$20 \mathrm{~cm}$ depth is that tillage can result in a compacted 'plow pan' layer directly below the tilled depth. This study is only 4 years old with the field being under 50 yrs of prior moldboard plow. This time may not be sufficient for the soil to recover from the previous management effects, especially at this depth. There was a significant treatment by depth 
interaction at the $30-40 \mathrm{~cm}$ depth. The NC-NT had the lowest soil bulk density values at this depth (Fig. 3.1a). Bulk density was numerically lower in the NC-Till management compared with the CC-Till management (Fig. 3.1a).

Results of bulk density for the sampling one week before cover crop termination and tillage (two depths, 0-10 and 10-20 cm) are shown in Table 3.2 and Figure 3.1b. Soil bulk density was not significantly affected by tillage or cover crop at the top $20 \mathrm{~cm}$ depth of soil just before cover crops were terminated. Bulk density was $8.4 \%$ lower in the $0-10$ cm depth compared to the 10-20 $\mathrm{cm}$ depth. Among other things, weather can affect the growth of winter cover crops (Dabney et al., 2001). Late cover crop planting on this site in the fall of 2013 did not allow the cover crops enough time to establish strong roots before going dormant during the winter. Low cover crop stands in our field during soil sampling (average cover crop biomass $=587 \mathrm{~kg} \mathrm{ha}^{-1}$ ) resulted in less cover crop effects on soil properties.

In order to understand the temporal variability in soil properties due to management, results from the $0-10 \mathrm{~cm}$ and $10-20 \mathrm{~cm}$ depths of soil samples collected two weeks after spring tillage and cover crop termination were used for comparison with results from the sampling one week before cover crop termination and tillage (two depths, 0-10 and $10-20 \mathrm{~cm}$ ). Therefore, the soil samples collected one week before cover crop termination and tillage also represented one-year post tillage. Averaged over the first two depths right after tillage $(0-10 \mathrm{~cm}$ and 10-20 cm depths of soil samples collected two weeks after spring tillage and cover crop termination), the significant treatment effects were the same as those averaged over four depths, with slight contrasts in the magnitude of the differences between the treatments (Table 3.2). Approximately one year after the previous 
tillage (one week before cover crops were terminated), the effect of tillage on soil bulk density decreased (Fig. 3.1a \& b). In fact, there was a higher increase in bulk density in tilled plots after one year compared with other treatments, especially in the $0-10 \mathrm{~cm}$ depth. This suggests that the benefit of tillage on bulk density does not persist over time.

\section{Soil water retention}

Soil water retention results for the main sampling (two weeks after spring tillage and cover crop termination; four depths, 0-10, 10-20, 20-30 and 30-40 cm) are shown in Table 3.3 and Figure 3.2. Depth had a significant effect on volumetric water content at all water pressures between 0.0 and $-33.0 \mathrm{kPa}$ (Table 3.3). Volumetric water content was higher at soil water pressures between saturation and $-5.0 \mathrm{kPa}$ in the $0-10 \mathrm{~cm}$ depth. This is consistent with lower bulk density at this depth. Below $-5.0 \mathrm{kPa}$ pressure, however, the relationship between water content and bulk density was not consistent. Water content at the 10-20 and 20-30 cm depths were similar due, in part, to the similarity in bulk density and texture at these depths (Tables $3.2 \& 3.3$ ).

Averaged over the four depths, there was no significant treatment effects on volumetric water content at all soil water pressures (Table 3.3). Apart from the first depth, no significant differences occurred in the other depths due to management (Fig. 3.2). Water content was higher at 0.0 and $-0.4 \mathrm{kPa}$ pressures for the tilled treatments compared with no-till treatments in the $0-10 \mathrm{~cm}$ depth (Fig. 3.2a). This mirrors the results from bulk density and it suggests that tillage can immediately improve the proportion of larger diameter pores that drain water at these pressures. This corresponds to the fact that the changes in soil water content resulting from tillage occurs only in the larger pore size range (Ahuja et al., 1998). Cameron (1978) related the shape of the water retention curve to bulk 
density and he found that the slope of the water retention curve decreased with an increase in bulk density. This was similar to our results. We found the lowest slope for water retention curve in the NC-NT management at the 10-20 cm depth (Fig. 3.2b) which also had the highest bulk density at this depth (Fig. 3.1a). The slope of the water retention curve also decreased with increasing soil depth from $0-10 \mathrm{~cm}$ to $10-20 \mathrm{~cm}$ depths (Fig. 3.2a \& b), which also corresponds with increasing soil bulk density (Fig. 3.1a). Treatment by depth interactions between the various treatments only occurred at pressures between saturation and $-2.5 \mathrm{kPa}$ pressures at depths below $10 \mathrm{~cm}$ (data not shown). For example, NC-NT had significantly lower water content at saturation in 10-20 cm depth while CC-Till management had the lowest water content at saturation in the $30-40 \mathrm{~cm}$ depth. A comparison of both tillage managements at $-33.0 \mathrm{kPa}$ pressure in the $0-10 \mathrm{~cm}$ depth indicated that water content was numerically higher in CC-Till management compared to NC-Till management. It is presumed that the roots of the previous cover crops are responsible for the slightly higher water content. In the 10-20 cm depth, however, the result was reversed.

Results of soil water retention measurement for the sampling one week before cover crop termination and tillage (two depths, $0-10$ and $10-20 \mathrm{~cm}$ ) are shown in Table 3.3. There was a significant effect of depth on volumetric soil water content at all soil water pressures between 0.0 and $-20 \mathrm{kPa}$ (Table 3.3). Volumetric water content was significantly higher in the $0-10 \mathrm{~cm}$ depth compared with $10-20 \mathrm{~cm}$ depth at pressures between saturation and $10.0 \mathrm{kPa}$ (Table 3.3) and this also corresponds with lower soil bulk density (Table 3.2) and higher macropores at this depth. The highest water content was observed in the $0-10 \mathrm{~cm}$ depth that also had the lowest bulk density values at this depth (Tables $3.2 \&$ 3.3). 
Significant treatment by depth (treatment $\mathrm{x}$ depth) interactions were also noticed at soil water pressures between -5.0 and $-10.0 \mathrm{kPa}$ (Table 3.3). At both pressures $(-5.0$ and -10.0 $\mathrm{kPa}$ ), a comparison of both tillage management practices demonstrated that water content was numerically higher in the $0-10 \mathrm{~cm}$ depth of CC-Till management compared with $\mathrm{NC}$ Till management. In the $10-20 \mathrm{~cm}$ depth, the results were reversed.

Averaged over the first two depths right after tillage $(0-10 \mathrm{~cm}$ and $10-20 \mathrm{~cm}$ depths of soil samples collected two weeks after spring tillage and cover crop termination), water retention data indicated a significant till vs no-till contrast on volumetric soil water content at 0.0 and $-0.04 \mathrm{kPa}$ pressures. Slopes of the water retention curves were different between the two tillage treatments. There was significantly higher water content with tillage management compared with no-till management (Fig. 3.2a). This may be due to the higher proportion of larger pores due to tillage. Volumetric water content was significantly higher in the 0-10 $\mathrm{cm}$ depth compared with $10-20 \mathrm{~cm}$ depth at soil water pressures between saturation and $-10.0 \mathrm{kPa}$ and this corresponds with lower soil bulk density (Table 3.2) and higher macropores at this depth.

Cover crop did not significantly affect soil water retention probably due to low densities and slow root establishment. Although observed higher water content at pressures is indicative of larger pore diameters in tilled plots right after tillage, this effect did not last over time. Approximately one growing season later (one week prior to cover crop termination), water content was not significantly different for tilled management compared to no-till. This suggests that the benefits of tillage in the context of soil water retention are only immediate and they diminish with time. In agriculturally intensive regions of the world, such as the Midwestern US, lower water retention and the possibility of higher soil 
water evaporation caused by tillage can lead to lower crop yield. This will be more evident in years with significantly less precipitation. Ghuman and Sur (2001) reported significantly lower corn and wheat (Triticum aestivum L.) yields under conventional tillage management compared with no-till due to higher soil moisture loss and they advocated the use of residue mulch and reduced or no-till to curb soil moisture evaporation and to improve yield.

\section{Pore size distributions}

Pore size distribution results for the main sampling (two weeks after spring tillage and cover crop termination; four depths) are shown in Table 3.4 and Figure 3.3 (a-d). Macropores and coarse mesopores were significantly affected by treatment. There was a significant depth effect on all pore sizes analyzed except for micropores. Significant interactions included tillage by cover crop (Till x CC) on macropores and treatment by depth (treatment $\mathrm{x}$ depth) on coarse and fine mesopores (Table 3.4). There was a significant 'Till vs NT' contrast for coarse mesopores. The Till vs NT contrast for coarse mesopores demonstrated that this pore size was about $32 \%$ higher due to tillage management compared with no-till (Table 3.4, Fig. 3.3b). The results suggest that the redistribution of pores by tillage is more evident in coarse mesopores. This may be because moldboard plow is very destructive and it may induce large pores. However, sampling cores can limit the amount of these large, horizontally continuous pores and captures more coarse mesopores, which can transmit more water as evidenced in water retention and $\mathrm{K}_{\text {sat }}$ results.

The highest macropores were found in the top $10 \mathrm{~cm}$ of the soil compared with other depths. The least proportion of macropores were found in the $10-20 \mathrm{~cm}$ depth (Table 3.4). This is in concert with the higher bulk density at this depth and the potential of a plow pan development in this layer due to several years of tillage. Coarse and fine mesopores 
and total pores were also significantly higher in the $0-10 \mathrm{~cm}$ depth due to tillage. This can temporarily increase water infiltration at this depth. The tillage by cover crop interaction for macropores showed that NT-NC management had the least macropores as expected, which also corresponds to bulk density and water retention results. Cover crop (0.063) had $24 \%$ higher macropores than no cover crop (0.051) (Table 3.4). This suggests that the macropores generated by cover crops can persist for some time. This is important during wet growing seasons as it may help reduce surface water ponding. Treatment by depth interactions indicated that coarse mesopores were significantly higher in the $0-10 \mathrm{~cm}$ depth when the soil was tilled compared with no-till (Fig. 3.3b). There was also an interaction between cover crop management at the $20-30 \mathrm{~cm}$ and $30-40 \mathrm{~cm}$ depths for fine mesopores. Fine mesopores were numerically higher in CC-NT management compared with NC-NT in the $20-30 \mathrm{~cm}$ depth. The results were reversed in the $30-40 \mathrm{~cm}$ depth.

Results of pore size distributions for the sampling one week before cover crop termination and tillage (two depths), which also represents results after one year of the previous tillage, are shown in Table 3.4 and Figure 3(e-h). There was a significant depth effect on macropores, fine mesopores and total pores. Significant interactions included tillage by cover crop (Till x CC) (Table 3.4). Macropores, fine mesopores and total pores were higher in the $0-10 \mathrm{~cm}$ depth compared with the $10-20 \mathrm{~cm}$ depth. This is in concert with soil bulk density and water retention results. A combination of tillage and cover crops may improve the proportion of larger pores that can help increase water infiltration and thus reduce runoff. Although not statistically different, macropores were $15 \%$ greater numerically due to cover crop compared to no cover crop management (Table 3.4). Although not statistically significant, cover crops had slightly higher total pores compared 
with no cover crop. This is similar to the findings of Lal et al. (1991), Villamil et al. (2006) and Haruna and Nkongolo (2015).

Averaged over two depths right after tillage, $(0-10 \mathrm{~cm}$ and $10-20 \mathrm{~cm}$ depths of soil samples collected two weeks after spring tillage and cover crop termination), the significant treatment effects were same as those averaged over four depths, with slight contrast in the magnitude of the differences between the treatments. In addition, there was a 'Till vs NT' contrast for micropores (data not shown). Tillage had slightly (about 8\%) more total pores compared with no-till. All pore sizes were higher in the top $0-10 \mathrm{~cm}$ depth compared with the 10-20 cm depth (Table 3.4, Fig. 3.3) and this is in concert with results on soil bulk density. Tillage by cover crop interaction indicated that NC-NT management had the least proportion of macropores (Table 3.4, Fig. 3.3a).

The results of pore size distribution were similar to that of Lipiec et al. (2006) and Sasal et al. (2006) who reported that the differences between tillage treatment was more pronounced in the top $0-10 \mathrm{~cm}$ of soil. However, this is contrary to an earlier study by Pagliai et al. (1989) who found no differences in the top soil $(0-10 \mathrm{~cm})$ due to chisel plow but noticed low porosity in the tilled plots in the $10-15 \mathrm{~cm}$ depth. The contrast in results are probably because over time and after a few rainfall events, surface crusts tend to develop faster in tilled plots. A temporal comparison of pore size distributions due to tillage showed a remarkable decrease in the proportion of pore sizes, especially for coarse mesopores, about one year after tillage (Fig. $3.3 \mathrm{~b} \&$ f). This was more evident in the $0-10$ $\mathrm{cm}$ depth where tillage effects were more pronounced. This means that tillage does not provide long-term porosity benefits. 
Pore size distribution is essential for water infiltration into the soil and transport within the soil. Due to the temporary porosity benefits provided by tillage, this management practice may not be suitable for regions with high annual precipitation and regions with relatively high precipitation over a short time. Such regions include the tropical wet (Af), and the tropical wet and dry (Aw and Am) climates on the Köppen Climate Classification System (Peel et al., 2007). Intensive rainfall over short periods may cause the soil to 'settle', thus diminishing the proportion of large pores quickly. This may lead to soil and nutrient loss and possible low yields. In such regions, the inclusion of cover crops may help transpire some water from the soil and their roots can hold the soils in place. This may help mitigate against soil and nutrient loss.

\section{Saturated hydraulic conductivity}

Saturated hydraulic conductivity $\left(\mathrm{K}_{\mathrm{sat}}\right)$ is highly dependent upon pore size continuity and arrangement. Saturated hydraulic conductivity results for the main sampling (two weeks after spring tillage and cover crop termination; four depths) are shown in Table 3.2 and Figure 3.1c. Saturated hydraulic conductivity values were significantly affected by treatment, depth and two interactions; tillage by cover crop and treatment by depth (Table 3.2). The 'Till vs NT' contrast revealed that tillage improved $\mathrm{K}_{\text {sat }}$ values by about $87 \%$ compared with no-till. This mirrors the results on soil bulk density and coarse mesopores. The higher $\mathrm{K}_{\mathrm{sat}}$ values with tillage suggests that tillage was responsible for higher proportions of large pores, especially coarse mesopores. Heard et al. (1988) and Carter and Kunelius (1986) also reported higher $\mathrm{K}_{\text {sat }}$ values with tillage compared with no-till. This is in contrast with the results of Joschko et al. (1992) and Bhattachryya et al. (2006) who reported higher $\mathrm{K}_{\text {sat }}$ values in no-till compared with tillage. Bhattachryya et al. (2006) 
suggested that no-till reduced the volume fraction of the large pores and increased the volume fraction of the smaller pores with higher pore connectivity, while Joschko et al. (1992) suggested that the burrows made by endogeic earthworms were responsible for higher $\mathrm{K}_{\text {sat }}$ values in no-till compared with tilled treatment.

Saturated hydraulic conductivity significantly decreased with soil depth (Table 3.2), with about two times higher $\mathrm{K}_{\text {sat }}$ values in the $0-10 \mathrm{~cm}$ of soil depth compared with the $10-20 \mathrm{~cm}$ depth, suggesting more tillage impacts at this depth. Tillage by cover crop interaction results indicated that CC-Till management had significantly higher $\mathrm{K}_{\text {sat }}$ values compared with other management combinations (Table 3.2). There was also a significant treatment by depth interaction on $\mathrm{K}_{\text {sat }}$ values and it shows that $\mathrm{K}_{\text {sat }}$ values were higher in the $0-10$ and $10-20 \mathrm{~cm}$ soil depth with tillage management compared with no-till management (Fig. 3.1c). Tillage improved $\mathrm{K}_{\text {sat }}$ values by $87 \%$ and $90 \%$ in the $0-10$ and 10 $20 \mathrm{~cm}$ depths respectively compared with no-till management. This is consistent with soil bulk density results. The significantly higher difference in $\mathrm{K}_{\text {sat }}$ values between tillage and no-till managements in the $10-20 \mathrm{~cm}$ depth could possibly be due to higher bulk density at this depth; however, tillage relieved some of the compaction in the tilled plots.

Results of $\mathrm{K}_{\text {sat }}$ for the sampling one week before cover crop termination and tillage (two depths), which also represents results after one year of the previous tillage, are shown in Table 3.2 and Figure 3.1d. Results show a significant depth effect on $\mathrm{K}_{\text {sat }}$ values. Saturated hydraulic conductivity values were $68 \%$ greater in the $0-10 \mathrm{~cm}$ depth compared with the 10-20 cm depth (Table 3.2). Although not statistically different due to low cover crop density, $\mathrm{K}_{\text {sat }}$ values (averaged over two depth) were about $32 \%$ higher in cover crop plots compared with no cover crop plots (Table 3.2). This is consistent with the slightly 
higher macropores for this treatment. The slightly higher $\mathrm{K}_{\text {sat }}$ values are indicative of the ability of cover crops to improve macropores and infiltration due to the activity of their roots. These roots can improve pore connectivity and soil structure (Villamil et al., 2006). This can be very important when dealing with pollutant movement and soil loss.

Averaged over two depths right after tillage, $(0-10 \mathrm{~cm}$ and $10-20 \mathrm{~cm}$ depths of soil samples collected two weeks after spring tillage and cover crop termination), there were significant treatment and depth effects on $\mathrm{K}_{\text {sat }}$ values (Table 3.2 and Fig. 3.1c). There was about $61 \%$ higher $\mathrm{K}_{\text {sat }}$ values in the $0-10 \mathrm{~cm}$ depth compared with the $10-20 \mathrm{~cm}$ depth. This is probably because tillage can immediately reduce bulk density and increase the proportion of larger pores that can lead to higher $\mathrm{K}_{\mathrm{sat}}$ values in this depth.

As with other soil properties analyzed, the benefits of tillage in improving $K_{\text {sat }}$ did not last over time. Approximately one year after tillage (one week before cover crop termination), $\mathrm{K}_{\text {sat }}$ values decreased significantly in tilled plots (Table 3.2). Results also show that the difference in bulk density values does not necessarily translate to $\mathrm{K}_{\text {sat }}$ values. For example, lower bulk density values do not always translate to higher $\mathrm{K}_{\text {sat }}$ values for similar soil management practices. Two reasons can be suggested. First, soil bulk density is a coarser (less sensitive) measurement compared with $\mathrm{K}_{\text {sat. }}$ Second, bulk density does not show pore continuity as evidenced in $\mathrm{K}_{\text {sat }}$ and soil bulk density values one week prior to cover crop termination and two weeks after cover crop termination (Table 3.2). The first reason is supported by the study conducted by Igbal et al. (1997). They reported lower variability in soil bulk density values compared with $\mathrm{K}_{\text {sat }}$ values. The second reason is supported by Ball et al. (1988) and Logsdon et al. (1990) who noted that differences in $\mathrm{K}_{\text {sat }}$ measurements do not translate to bulk density measurements due to pore tortuosity. 
The higher bulk density and lower proportion of large pores and $\mathrm{K}_{\text {sat }}$ noticed in the 10-20 $\mathrm{cm}$ depth compared to the $0-10 \mathrm{~cm}$ depth under the tillage management suggests that vertical water movement may be hindered by the 'plow pan'. This may be more evident after several years of tillage. Furthermore, results from the current study suggest that tillage, over time, may not have any beneficial effects on soil hydraulic properties. This may be the reason some farm managers till the soil every growing season; in order to temporarily alleviate the effects of the previous tillage. This may lead to an endless cycle of annual tillage that may increase soil and nutrient loss, farm management cost and reduce crop yield. A viable alternative may be the inclusion of cover crops into crop production systems to stabilize and improve soil hydraulic properties over time. These crops can be planted to help transpire excess water after the harvest of the previous cash crops (in regions of high early season precipitation) or along with the cash crops (in regions with excessive precipitation during the growing season).

\section{SUMMARY AND CONCLUSIONS}

This study was conducted to evaluate the influence of tillage and cover crop soil management practices on the hydraulic properties of a silt loam soil. Results showed different effects of these management practices on soil bulk density, water retention, pore size distribution and saturated hydraulic conductivity. For example, soil bulk density was $13 \%$ lower when the soil was tilled compared with no-tillage and this effect was more prominent in the top $10 \mathrm{~cm}$ of the soil. As a result of lower soil bulk density, we found a significantly higher water content at 0.0 and $-0.4 \mathrm{kPa}$ soil water pressures in tillage compared with no-till management. Results of pore size distributions indicated that a combination of tillage and cover crops greatly improved the proportion of macropores (> 
$1000 \mu \mathrm{m}$ diameter) compared with any other management combinations. This can possibly increase water infiltration and reduce runoff.

Even though we noticed significantly higher water content at soil water pressures indicative of larger pore diameters in tilled plots right after tillage, this effect did not last over time. Approximately one growing season later, water content was not significantly different. This suggests that the benefits of tillage in the context of soil hydraulic properties are only immediate and they may diminish with time. Results also revealed that some hydraulic properties improve with a combination of both tillage and cover crop management practices. This underscores the need for producers and farm managers to diversify their management portfolio to ensure better soil management and improved productivity.

\section{ACKNOWLEDGEMENTS}

Funded by the USDA-NIFA research grant (Award No. 2011-68002-30190); 'Cropping Systems Coordinated Agricultural Project: Climate Change Mitigation, and Adaptation in Corn-based Cropping Systems'. The authors appreciate the help rendered by Phil Markway, Eda Akdemir, Ahsan Rajper, Janith Chandrasoma and Evren Cetin during sample collection. 


\section{REFERENCES}

Abdollahi L, Munkholm L J, Garbout A. 2014. Tillage System and Cover Crop Effects on Soil Quality: II. Pore Characteristics. Soil Sci Soc Am J. 78: 271--279.

Ahuja L R, Fiedler F, Dunn G H, Benjamin J G, Garrison A. 1998. Changes in soil water retention curves due to tillage and natural reconsolidation. Soil Sci Soc of Am J. 62: 1228--1233.

Auler A C, Miara S, Pires L F, da Fonseca A F, Barth G. 2014. Soil physico-hydrical properties resulting from the management in Integrated Production Systems. Rev Ciênc Agronômica 45: 976--989.

Azooz R H, Arshad M A. 1996. Soil infiltration and hydraulic conductivity under longterm no-tillage and conventional tillage systems. Can J Soil Sci. 76: 143--152.

Azooz R H, Arshad M A. 2001. Soil water drying and recharge rates as affected by tillage under continuous barley and barley-canola cropping systems in northwestern Canada. Can J Soil Sci. 81: 45--52.

Anderson S H, Gantzer C J, Brown J R. 1990. Soil physical properties after 100 years of continuous cultivation. J Soil Water Conserv. 45: 117--121.

Ball B C, O'sullivan M F, Hunter R. 1988. Gas diffusion, fluid flow and derived pore continuity indices in relation to vehicle traffic and tillage. J Soil Sci. 39: 327--339.

Benjamin J G. 1993. Tillage effects on near-surface soil hydraulic properties. Soil Tillage Res. 26: 277--288.

Bhattacharyya R, Prakash V, Kundu S, Gupta H S. 2006. Effect of tillage and crop rotations on pore size distribution and soil hydraulic conductivity in sandy clay loam soil of the Indian Himalayas. Soil Tillage Res. 86: 129--140.

Blanco-Canqui H, Mikha M M, Presley D R, Claassen M M. 2011. Addition of cover crops enhances no-till potential for improving soil physical properties. Soil Sci Soc Am J. 75: 1471--1482.

Brandt S A. 1992. Zero vs. conventional tillage and their effects on crop yield and soil moisture. Can J Plant Sci. 72: 679--688.

Cameron D R. 1978. Variability of soil water retention curves and predicted hydraulic conductivities on a small plot. Soil Sci. 126: 364--371.

Carter M R, Kunelius H T. 1986. Comparison of tillage and direct-drilling for Italian ryegrass on the properties of a fine sandy loam soil. Can J Soil Sci 66: 197--207.

Chang C, Lindwall C W. 1992. Effects of tillage and crop rotation on physical properties of a loam soil. Soil Tillage Res 22: 383--389. 
Conant R T, Easter M, Paustian K, Swan A, Williams S. 2007. Impacts of periodic tillage on soil C stocks: A synthesis. Soil Tillage Res. 95: 1--10.

Dabney S M, Delgado J A, Reeves D W. 2001. Using winter cover crops to improve soil and $\quad$ water quality. Commun. Soil Sci Pl Anal. 32: 1221--1250.

Dam R F, Mehdi B B, Burgess M S E, Madramootoo C A, Mehuys G R, Callum I R. 2005. Soil bulk density and crop yield under eleven consecutive years of corn with different tillage and residue practices in a sandy loam soil in central Canada. Soil Tillage Res. 84: 41--53.

Dane J H, Topp C, Campbell G S, Horton R, Jury W A, Nielsen D R, van Es H M, Wierenga P J, Topp G C. 2002. Physical Methods. In Dane J H, Hopmans J W, (ed). Methods of Soil Analysis. Part 4. ASA and SSSA, Madison, WI. pp. 675-719.

Ghuman B S, Sur H S. 2001. Tillage and residue management effects on soil properties and yields of rainfed maize and wheat in a sub-humid subtropical climate. Soil Tillage Res. 58: 1--10.

Haruna, S I, Nkongolo N V. 2015. Effects of tillage, rotation and cover crop on the physical properties of a silt-loam soil. Intern Agrophys. 29: 137--145.

Haverkamp R, Leij F J, Fuentes C, Sciortino A, Ross P J. 2005. Soil water retention. Soil Sci Soc Am J. 69: 1881--1890.

Heard J R, Kladivko E J, Mannering J V. 1988. Soil macroporosity, hydraulic conductivity and air permeability of silty soils under long-term conservation tillage in Indiana. Soil Tillage Res. 11: 1-18.

Iqbal J, Thomasson J A, Jenkins J N, Owens P R, Whisler F D. 2005. Spatial variability analysis of soil physical properties of alluvial soils. Soil Sci Soc Am J. 69: 1338-1350.

Joschko M, Sochtig W, Larink O. 1992. Functional relationship between earthworm burrows and soil water movement in column experiments. Soil Biol Biochem. 24: $1545-1547$.

Jury W A, Gardner W R, Gardner W H. 1991. Soil Physics. John Wiley \& Sons, Inc., New York.

Keisling T C, Scott H D, Waddle B A, Williams W, Frans R E. 1990. Effects of winter cover crops on cotton yield and selected soil properties. In: Proc. Beltwide Cotton Production Research Conference. Las Vegas, NV. pp. 492--496.

Kladivko E J, Helmers M J, Abendroth L J, Herzmann D, Lal R, Castellano M J, Mueller D S, Sawyer J E, Anex R P, Arritt R W, Basso B, Bonta J V, Bowling L C, Cruse R M, Fausey N R, Frankenberger J R, Gassman P W, Gassmann A J, Kling C L, 
Kravchenko A, Lauer J G, Miguez F E, Nafziger E D, Nkongolo N, O'Neal M, Owens L B, Owens P R, Scharf P, Shipitalo M J, Strock J S, Villamil M B. 2014. Standardized research protocols enable transdisciplinary research of climate variation impacts in corn production systems. J Soil Water Res. 69: 532--542.

Lal R, Regnier E, Eckert D J, Edwards W M, Hammond R. 1991. Expectations of cover crops for sustainable agriculture. In Hargrove W L, (ed.) Cover crops for clean water. Soil and Water Society. Ankeny, Iowa. pp 1--11.

Lampurlanés J, Cantero-Martinez C. 2003. Soil bulk density and penetration resistance under different tillage and crop management systems and their relationship with barley root growth. Agron. J. 95: 526--536.

Leij F J, Ghezzehei T A, Or D. 2002. Modeling the dynamics of the soil pore-size distribution. Soil Tillage Res. 64: 61--78.

Lipiec J, Kuś J, Słowińska-Jurkiewicz A, Nosalewicz A. 2006. Soil porosity and water infiltration as influenced by tillage methods. Soil and Tillage Res. 89: 210--220.

Logsdon S D, Jaynes D B. 1996. Spatial variability of hydraulic conductivity in a cultivated field at different times. Soil Sci Soc Am J. 60: 703--709.

Logsdon S, Allmaras R R, Wu L, Swan J B, Randall G W. 1990. Macroporosity and its relation to saturated hydraulic conductivity under different tillage practices. Soil Sci Soc Am J. 54: 1096--1101.

Ogle S M, Jay Breidt F, Eve M D, Paustian K. 2003. Uncertainty in estimating land use and management impacts on soil organic carbon storage for US agricultural lands between 1982 and 1997. Glob Change Biol. 9: 1521--1542.

Osunbitan J A, Oyedele D J, Adekalu K O. 2005. Tillage effects on bulk density, hydraulic conductivity and strength of a loamy sand soil in southwestern Nigeria. Soil Tillage Res. 82: 57--64.

Pagliai M, Pezzarossa B, Mazzoncini M, Bonari E. 1989. Effects of tillage on porosity and microstructure of a loam soil. Soil Technol. 2: 345--358.

Peel M C, Finlayson B L, McMahon T A. 2007. Updated world map of the Köppen-Geiger climate classification. Hydrol. \& Earth Syst. Sci. Disc. 4: 439 -- 473.

Prieksat M A, Kaspar T C, Ankeny M D. 1994. Positional and temporal changes in ponded infiltration in a corn field. Soil Sci Soc Am J. 58: 181--184.

Reynolds W D, Elrick D E. 2002. Constant head soil core (tank). In Dane J H, Hopmans J W (ed.) Methods of Soil Analysis. Part 4. ASA and SSSA, Madison, WI. pp 804-808 .

SAS (Statistical Analysis Systems) Institute Inc. 2013. SAS user's guide. Statistics. SAS Instit., Cary, NC. 
Sasal M C, Andriulo A E, Taboada M A. 2006. Soil porosity characteristics and water movement under zero tillage in silty soils in Argentinian Pampas. Soil and Tillage Res. 87: 9--18.

Shukla M K. 2013. Soil physics: An introduction. CRC Press.

Sparling G P, West A W. 1989. Importance of soil water content when estimating soil microbial C, N and P by the fumigation-extraction methods. Soil Biol Biochem. 21: 245-253.

Sylvia D M, Fuhrmann J J, Hartel P, Zuberer D A.2005. Principles and applications of soil microbiology. Pearson Prentice Hall. Upper Saddle River, NJ.

Troeh F R, Hobbs J A. Donahue R L. 2003. Soil and water conservation for productivity and environmental protection. Prentice Hall.

Uhland R E. 1950. Physical properties of soils as modified by crops and management. Proc Soil Sci Soc Am. 14: 361--366.

Villamil M B, Bollero G A, Darmody R G, Simmons F W, Bullock D G. 2006. No-till corn/soybean systems including winter cover crops. Soil Sci Soc Am J. 70: 1936-1944.

Wagger M G, Denton H P. 1989. Influence of cover crop and wheel traffic on soil physical properties in continuous no-till com. Soil Sci Soc Am J. 53:1206--1210.

Walczak R T, Moreno F, Sławiński C, Fernandez E, Arrue J L. 2006. Modeling of soil water retention curve using soil solid phase parameters. J Hydrol. 329: 527-533. 
Table 3.1 Selected soil physical and chemical properties of the Waldron silt loam at various soil depths and horizons.

\begin{tabular}{lllllll}
\hline $\begin{array}{l}\text { Depth } \\
(\mathrm{cm})\end{array}$ & Horizon & $\begin{array}{l}\text { Clay } \\
\left(\mathrm{g} \mathrm{kg}^{-1}\right)\end{array}$ & $\begin{array}{l}\text { Silt } \\
\left(\mathrm{g} \mathrm{kg}^{-1}\right)\end{array}$ & $\begin{array}{l}\text { Sand } \\
\left(\mathrm{g} \mathrm{kg}^{-1}\right)\end{array}$ & $\begin{array}{l}\mathrm{OM}^{\mathrm{a})} \\
\left(\mathrm{g} \mathrm{kg}^{-1}\right)\end{array}$ & $\begin{array}{l}\mathrm{pH} \\
\left(\mathrm{H}_{2} \mathrm{O}\right)\end{array}$ \\
\hline $0-10$ & $\mathrm{Ap}$ & 201.1 & 650.6 & 148.3 & 16.8 & 6.71 \\
$10-20$ & $\mathrm{Ap}$ & 208.5 & 633.0 & 158.5 & 16.6 & 6.80 \\
$20-40$ & $\mathrm{C} 1$ & 198.5 & 631.2 & 170.3 & 16.6 & 6.79 \\
$40-60$ & $\mathrm{Cg} 1$ & 209.7 & 638.4 & 151.9 & 16.5 & 6.85 \\
\hline
\end{tabular}

a) $\mathrm{OM}=$ Organic matter 
Table 3.2 Means and analysis of variance of saturated hydraulic conductivity (Ksat) and soil bulk density for the treatments and soil depths one week before cover crop termination ( 2 depths) and two weeks after cover crop termination ( 4 depths for the main sampling and 2 depths for comparison with samples taken one week before cover crop termination). Tillage also occurred two weeks after cover crop termination.

\begin{tabular}{|c|c|c|c|c|c|c|}
\hline \multirow[b]{2}{*}{ Treatment } & \multicolumn{2}{|c|}{$\begin{array}{c}\text { Post cover crop } \\
\text { termination ( } 4 \text { depths) }\end{array}$} & \multicolumn{2}{|c|}{$\begin{array}{c}\text { Prior to cover crop } \\
\text { termination ( } 2 \text { depths) }\end{array}$} & \multicolumn{2}{|c|}{$\begin{array}{r}\text { termination } \\
\text { depths })\end{array}$} \\
\hline & $\begin{array}{c}\mathrm{K}_{\mathrm{sat}} \\
\left(\mathrm{mm} \mathrm{h}^{-1}\right)\end{array}$ & $\begin{array}{c}\text { Bulk } \\
\text { Density (g } \\
\mathrm{cm}^{-3} \text { ) }\end{array}$ & $\begin{array}{c}\mathrm{K}_{\mathrm{sat}} \\
\left(\mathrm{mm} \mathrm{h}^{-1}\right)\end{array}$ & $\begin{array}{c}\text { Bulk } \\
\text { Density } \\
\left(\mathrm{g} \mathrm{cm}^{-3}\right)\end{array}$ & $\begin{array}{c}\mathrm{K}_{\mathrm{sat}} \\
\left(\mathrm{mm} \mathrm{h}^{-1}\right)\end{array}$ & $\begin{array}{c}\text { Bulk } \\
\text { Density } \\
\left(\mathrm{g} \mathrm{cm}^{-3}\right)\end{array}$ \\
\hline \multicolumn{7}{|l|}{ Treatment } \\
\hline CC-Tilla) & $14.21 \mathrm{a}^{\mathrm{b})}$ & 1.46 & 3.12 & 1.48 & $36.78 \mathrm{a}$ & $1.37 \mathrm{~b}$ \\
\hline CC-NT & $2.97 \mathrm{~b}$ & 1.49 & 9.36 & 1.55 & $4.46 \mathrm{~b}$ & $1.47 \mathrm{ab}$ \\
\hline NC-Till & $8.84 \mathrm{ab}$ & 1.42 & 6.31 & 1.46 & $32.46 \mathrm{a}$ & $1.35 b$ \\
\hline NC-NT & $2.00 \mathrm{~b}$ & 1.50 & 2.23 & 1.47 & $3.10 \mathrm{~b}$ & $1.53 \mathrm{a}$ \\
\hline \multicolumn{7}{|l|}{ Depth } \\
\hline $0-10 \mathrm{~cm}$ & $18.20 \mathrm{a}$ & $1.32 \mathrm{~b}$ & $8.00 \mathrm{a}$ & $1.42 \mathrm{~b}$ & $18.20 \mathrm{a}$ & $1.32 \mathrm{~b}$ \\
\hline $10-20 \mathrm{~cm}$ & $7.06 \mathrm{~b}$ & $1.53 \mathrm{a}$ & $2.53 b$ & $1.55 \mathrm{a}$ & $7.05 b$ & $1.53 \mathrm{a}$ \\
\hline $20-30 \mathrm{~cm}$ & $2.93 \mathrm{c}$ & $1.53 \mathrm{a}$ & - & - & - & - \\
\hline $30-40 \mathrm{~cm}$ & $1.98 \mathrm{c}$ & $1.48 \mathrm{a}$ & - & - & - & - \\
\hline \multicolumn{7}{|c|}{ Analysis of variance $p>F$} \\
\hline Treatment & $<0.01$ & 0.64 & 0.41 & 0.27 & $<0.01$ & 0.16 \\
\hline Till vs $\mathrm{NT}^{\mathrm{a})}$ & $<0.01$ & 0.28 & 0.96 & 0.25 & $<0.01$ & 0.04 \\
\hline $\mathrm{CC}$ vs $\mathrm{NC}$ & 0.30 & 0.80 & 0.58 & 0.18 & 0.32 & 0.74 \\
\hline Till x CC & 0.04 & 0.60 & 0.13 & 0.33 & 0.62 & 0.50 \\
\hline Depth & $<0.01$ & $<0.01$ & 0.02 & 0.07 & 0.01 & $<0.01$ \\
\hline $\begin{array}{l}\text { Treatment } \mathrm{x} \\
\text { Depth }\end{array}$ & 0.05 & 0.01 & 0.52 & 0.66 & 0.83 & 0.26 \\
\hline
\end{tabular}


Table 3.3 Means and analysis of variance of volumetric water content as a function of soil water pressure for the treatments and soil depths two weeks after cover crop termination and one week prior to cover crop termination. Tillage also occurred two weeks after cover crop termination.

\begin{tabular}{|c|c|c|c|c|c|c|c|c|}
\hline & \multicolumn{8}{|c|}{ Soil water pressure $\left(\mathrm{m}^{3} \mathrm{~m}^{-3}\right)$ two weeks after cover crop termination } \\
\hline & $0.0 \quad \mathrm{kPa}$ & $-0.4 \mathrm{kPa}$ & $-1.0 \mathrm{kPa}$ & $-2.5 \mathrm{kPa}$ & $-5.0 \mathrm{kPa}$ & $-10.0 \mathrm{kPa}$ & $-20.0 \mathrm{kPa}$ & $-33.0 \mathrm{kPa}$ \\
\hline \multicolumn{9}{|l|}{ Treatment } \\
\hline CC-Till ${ }^{\mathrm{a}}$ & 0.485 & 0.428 & 0.395 & 0.374 & 0.351 & 0.344 & 0.325 & 0.299 \\
\hline CC-NT & 0.481 & 0.418 & 0.398 & 0.382 & 0.371 & 0.359 & 0.345 & 0.315 \\
\hline NC-Till & 0.493 & 0.438 & 0.407 & 0.387 & 0.369 & 0.350 & 0.332 & 0.309 \\
\hline NC-NT & 0.469 & 0.423 & 0.403 & 0.388 & 0.374 & 0.366 & 0.355 & 0.323 \\
\hline \multicolumn{9}{|l|}{ Depth } \\
\hline $0-10 \mathrm{~cm}$ & $0.526 a^{b)}$ & $0.460 \mathrm{a}$ & $0.424 \mathrm{a}$ & $0.398 \mathrm{a}$ & $0.375 \mathrm{a}$ & $0.359 \mathrm{ab}$ & $0.338 b$ & $0.304 b$ \\
\hline $10-20 \mathrm{~cm}$ & $0.455 b$ & $0.410 \mathrm{~b}$ & $0.387 \mathrm{~b}$ & $0.369 b$ & $0.363 b$ & $0.358 \mathrm{ab}$ & $0.345 \mathrm{ab}$ & $0.305 b$ \\
\hline $20-30 \mathrm{~cm}$ & $0.455 b$ & $0.406 \mathrm{~b}$ & $0.383 b$ & $0.372 b$ & $0.360 \mathrm{~b}$ & $0.349 b$ & $0.336 \mathrm{~b}$ & $0.316 \mathrm{ab}$ \\
\hline $30-40 \mathrm{~cm}$ & $0.493 \mathrm{ab}$ & $0.432 \mathrm{ab}$ & $0.409 \mathrm{ab}$ & $0.391 \mathrm{a}$ & $0.373 \mathrm{a}$ & $0.364 \mathrm{a}$ & $0.353 \mathrm{a}$ & $0.324 \mathrm{a}$ \\
\hline \multicolumn{9}{|c|}{ Analysis of variance $p>F$} \\
\hline Treatment & 0.56 & 0.13 & 0.44 & 0.39 & 0.36 & 0.35 & 0.26 & 0.66 \\
\hline Till vs $\mathrm{NT}^{\mathrm{a})}$ & 0.27 & 0.28 & 0.91 & 0.63 & 0.47 & 0.31 & 0.15 & 0.24 \\
\hline CC vs NC & 0.87 & 0.40 & 0.53 & 0.44 & 0.53 & 0.67 & 0.49 & 0.48 \\
\hline Till x CC & 0.24 & 0.56 & 0.56 & 0.73 & 0.69 & 0.98 & 0.97 & 0.91 \\
\hline Depth & $<0.01$ & $<0.01$ & $<0.01$ & $<0.01$ & $<0.01$ & $<0.01$ & $<0.01$ & 0.02 \\
\hline Treatment $\mathrm{x}$ Depth & 0.02 & $<0.01$ & 0.04 & 0.05 & 0.01 & 0.03 & 0.03 & 0.01 \\
\hline
\end{tabular}




\begin{tabular}{|c|c|c|c|c|c|c|c|c|}
\hline & \multicolumn{8}{|c|}{ Soil water pressure $\left(\mathrm{m}^{3} \mathrm{~m}^{-3}\right)$ one week prior to cover crop termination } \\
\hline & $0.0 \quad \mathrm{kPa}$ & $-0.4 \mathrm{kPa}$ & $-1.0 \mathrm{kPa}$ & $-2.5 \mathrm{kPa}$ & $-5.0 \mathrm{kPa}$ & $-10.0 \mathrm{kPa}$ & $-20.0 \mathrm{kPa}$ & $-33.0 \mathrm{kPa}$ \\
\hline \multicolumn{9}{|l|}{ Treatment } \\
\hline CC-Till & 0.468 & 0.414 & 0.398 & 0.385 & 0.360 & 0.368 & 0.351 & 0.306 \\
\hline CC-NT & 0.464 & 0.412 & 0.402 & 0.392 & 0.388 & 0.381 & 0.368 & 0.346 \\
\hline NC-Till & 0.448 & 0.410 & 0.388 & 0.383 & 0.376 & 0.368 & 0.349 & 0.302 \\
\hline NC-NT & 0.484 & 0.446 & 0.432 & 0.423 & 0.416 & 0.408 & 0.399 & 0.353 \\
\hline \multicolumn{9}{|l|}{ Depth } \\
\hline $0-10 \mathrm{~cm}$ & $0.526 \mathrm{a}$ & $0.460 \mathrm{a}$ & $0.424 \mathrm{a}$ & $0.398 \mathrm{a}$ & $0.375 \mathrm{a}$ & $0.359 \mathrm{a}$ & $0.338 b$ & 0.304 \\
\hline $10-20 \mathrm{~cm}$ & $0.455 b$ & $0.410 \mathrm{~b}$ & $0.387 b$ & $0.369 b$ & $0.363 b$ & $0.358 b$ & $0.345 \mathrm{a}$ & 0.305 \\
\hline \multicolumn{9}{|c|}{ Analysis of variance $p>F$} \\
\hline Treatment & 0.99 & 0.90 & 0.98 & 0.98 & 0.98 & 0.97 & 0.94 & 0.92 \\
\hline Till vs NT & 0.96 & 0.99 & 0.79 & 0.80 & 0.72 & 0.70 & 0.61 & 0.57 \\
\hline $\mathrm{CC}$ vs NC & 0.90 & 0.82 & 0.92 & 0.88 & 0.96 & 0.98 & 0.99 & 0.78 \\
\hline Till $x$ CC & 0.95 & 0.51 & 0.76 & 0.77 & 0.82 & 0.82 & 0.76 & 0.84 \\
\hline Depth & $<0.01$ & 0.01 & $<0.01$ & $<0.01$ & $<0.01$ & $<0.01$ & $<0.01$ & 0.81 \\
\hline Treatment $x$ Depth & 0.59 & 0.92 & 0.1 & 0.07 & 0.03 & 0.04 & 0.09 & 0.80 \\
\hline
\end{tabular}

${ }^{\text {a) }}$ CC-Till = cover with tillage; CC-NT = cover crop with no till; NC-Till = no cover crop with tillage; NC-NT = no cover crop with no-till; Till = tillage; NT $=$ no till; Till $\mathrm{x} C \mathrm{C}=$ Tillage by cover crop interaction; Treatment $\mathrm{x}$ Depth $=$ Treatment by Depth interaction.

b) Mean comparisons were only made when $P$ values for the main effects were $\leq 0.05$. Means with different letters for a soil water pressure are significantly different at the 0.05 probability level. 
Table 3.4 Means and analysis of variance of pore size distributions for the treatments and soil depths two weeks after cover crop termination and one week prior to cover crop termination. Tillage also occurred two weeks after cover crop termination.

\begin{tabular}{|c|c|c|c|c|c|}
\hline & \multicolumn{5}{|c|}{ Pore sizes $\left(\mathrm{m}^{3} \mathrm{~m}^{-3}\right)$ two weeks after cover crop termination } \\
\hline & $\begin{array}{l}\text { Macropores } \\
(>1,000 \mu \mathrm{m})\end{array}$ & $\begin{array}{l}\text { Coarse Mesopores } \\
(>60 \text { to } 1,000 \mu \mathrm{m})\end{array}$ & $\begin{array}{l}\text { Fine Mesopores } \\
(10 \text { to } 60 \mu \mathrm{m})\end{array}$ & $\begin{array}{l}\text { Micropores } \\
(<10 \mu \mathrm{m})\end{array}$ & $\begin{array}{c}\text { Total pores } \\
\left(\mathrm{m}^{3} \mathrm{~m}^{-3}\right)\end{array}$ \\
\hline \multicolumn{6}{|l|}{ Treatment } \\
\hline CC-Till ${ }^{\text {a) }}$ & $0.058 \mathrm{ab}^{\mathrm{b})}$ & $0.071 \mathrm{a}$ & 0.055 & 0.292 & 0.476 \\
\hline CC-NT & $0.068 \mathrm{a}$ & $0.048 \mathrm{c}$ & 0.055 & 0.315 & 0.486 \\
\hline NC-Till & $0.058 \mathrm{ab}$ & $0.067 \mathrm{~b}$ & 0.065 & 0.302 & 0.493 \\
\hline NC-NT & $0.043 b$ & $0.046 \mathrm{c}$ & 0.051 & 0.323 & 0.462 \\
\hline \multicolumn{6}{|l|}{ Depth } \\
\hline $0-10 \mathrm{~cm}$ & $0.068 \mathrm{a}$ & $0.086 \mathrm{a}$ & $0.068 \mathrm{a}$ & 0.306 & $0.529 \mathrm{a}$ \\
\hline $10-20 \mathrm{~cm}$ & $0.044 \mathrm{c}$ & $0.054 \mathrm{~b}$ & $0.055 b$ & 0.301 & $0.454 b$ \\
\hline $20-30 \mathrm{~cm}$ & $0.051 b$ & $0.045 b$ & $0.050 \mathrm{~b}$ & 0.304 & $0.450 \mathrm{~b}$ \\
\hline $30-40 \mathrm{~cm}$ & $0.063 \mathrm{ab}$ & $0.047 \mathrm{~b}$ & $0.053 b$ & 0.321 & $0.485 b$ \\
\hline \multicolumn{6}{|c|}{ Analysis of variance $p>F$} \\
\hline Treatment & 0.02 & 0.01 & 0.07 & 0.61 & 0.73 \\
\hline Till vs $\mathrm{NT}^{\mathrm{a})}$ & 0.71 & $<0.01$ & 0.23 & 0.16 & 0.56 \\
\hline $\mathrm{CC}$ vs NC & 0.09 & 0.40 & 0.58 & 0.55 & 0.84 \\
\hline Till x CC & 0.03 & 0.13 & 0.15 & 0.51 & 0.40 \\
\hline Depth & 0.05 & $<0.01$ & $<0.01$ & 0.06 & $<0.01$ \\
\hline Treatment x Depth & 0.39 & 0.03 & 0.03 & 0.46 & 0.01 \\
\hline
\end{tabular}




\begin{tabular}{|c|c|c|c|c|c|}
\hline & \multicolumn{5}{|c|}{ Pore sizes $\left(\mathrm{m}^{3} \mathrm{~m}^{-3}\right)$ one week prior cover crop termination } \\
\hline & $\begin{array}{l}\text { Macropores } \\
(>1,000 \mu \mathrm{m})\end{array}$ & $\begin{array}{l}\text { Coarse Mesopores } \\
(>60 \text { to } 1,000 \mu \mathrm{m})\end{array}$ & $\begin{array}{l}\text { Fine Mesopores } \\
(10 \text { to } 60 \mu \mathrm{m})\end{array}$ & $\begin{array}{l}\text { Micropores } \\
(<10 \mu \mathrm{m})\end{array}$ & $\begin{array}{c}\text { Total pores } \\
\left(\mathrm{m}^{3} \mathrm{~m}^{-3}\right)\end{array}$ \\
\hline \multicolumn{6}{|l|}{ Treatment } \\
\hline CC-Till & 0.045 & 0.046 & 0.062 & 0.325 & 0.477 \\
\hline CC-NT & 0.056 & 0.028 & 0.056 & 0.333 & 0.474 \\
\hline NC-Till & 0.050 & 0.040 & 0.069 & 0.314 & 0.472 \\
\hline NC-NT & 0.036 & 0.041 & 0.064 & 0.331 & 0.472 \\
\hline \multicolumn{6}{|l|}{ Depth } \\
\hline $0-10 \mathrm{~cm}$ & $0.055 \mathrm{a}$ & 0.037 & $0.084 \mathrm{a}$ & 0.327 & $0.504 \mathrm{a}$ \\
\hline $10-20 \mathrm{~cm}$ & $0.038 b$ & 0.041 & $0.041 b$ & 0.324 & $0.444 b$ \\
\hline \multicolumn{6}{|c|}{ Analysis of variance $\mathbf{p}>\mathbf{F}$} \\
\hline Treatment & 0.62 & 0.08 & 0.96 & 0.92 & 0.99 \\
\hline Till vs NT & 0.90 & 0.08 & 0.76 & 0.57 & 0.96 \\
\hline $\mathrm{CC}$ vs NC & 0.51 & 0.39 & 0.67 & 0.78 & 0.90 \\
\hline Till x CC & 0.28 & 0.05 & 0.97 & 0.84 & 0.95 \\
\hline Depth & 0.01 & 0.62 & 0.06 & 0.81 & 0.01 \\
\hline Treatment x Depth & 0.77 & 0.45 & 0.93 & 0.80 & 0.59 \\
\hline
\end{tabular}

a) CC-Till = cover with tillage; CC-NT = cover crop with no till; NC-Till = no cover crop with tillage; NC-NT = no cover crop with no-till; Till = tillage; $\mathrm{NT}=$ no till; Till $\mathrm{x}$ CC $=$ Tillage by cover crop interaction; Treatment $\mathrm{x}$ Depth $=$ Treatment by Depth interaction.

${ }^{b)}$ Mean comparisons were only made when $P$ values for the main effects were $\leq 0.05$. Means with different letters for a pore size are significantly different at the 0.05 probability level. 
(a)

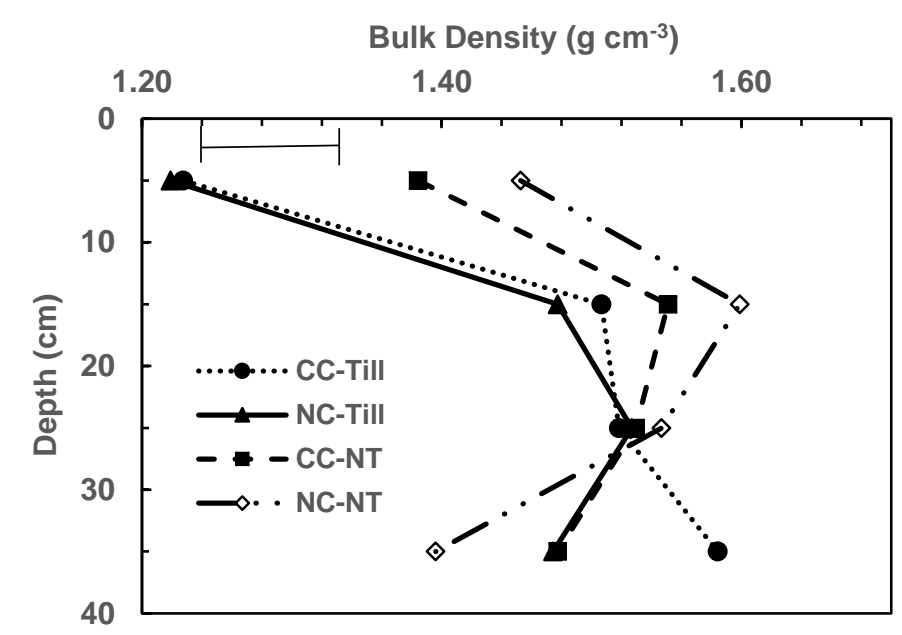

(C)

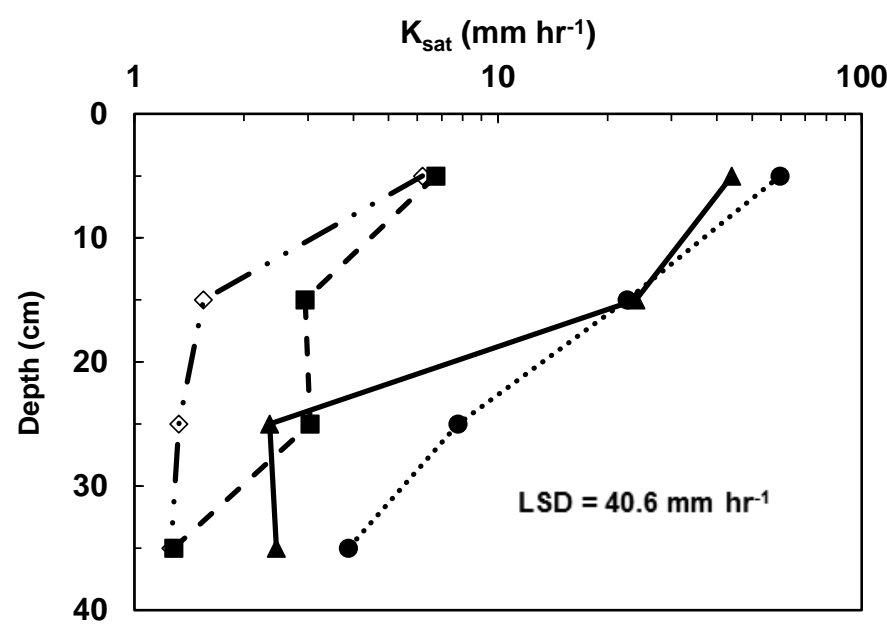

(b)

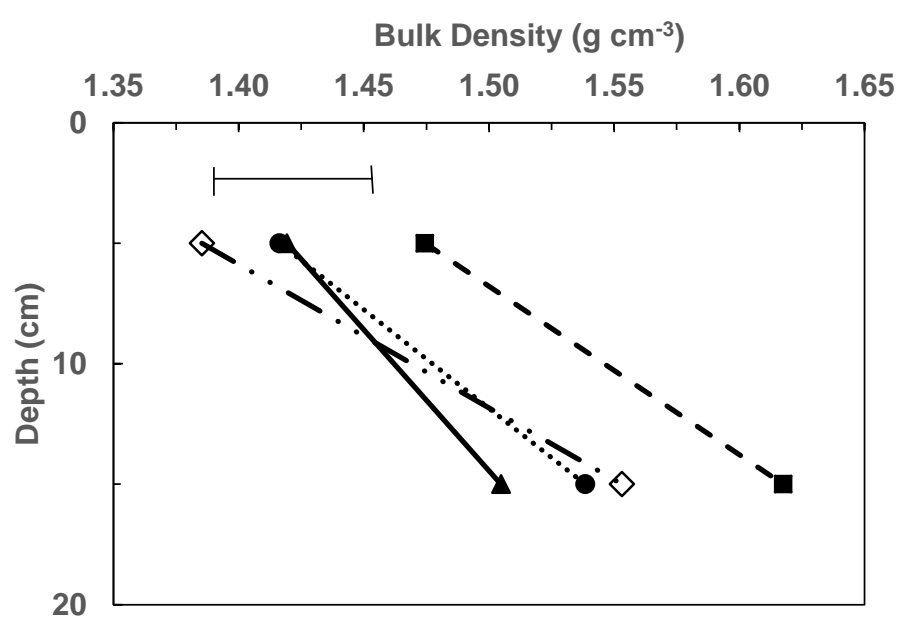

(d)

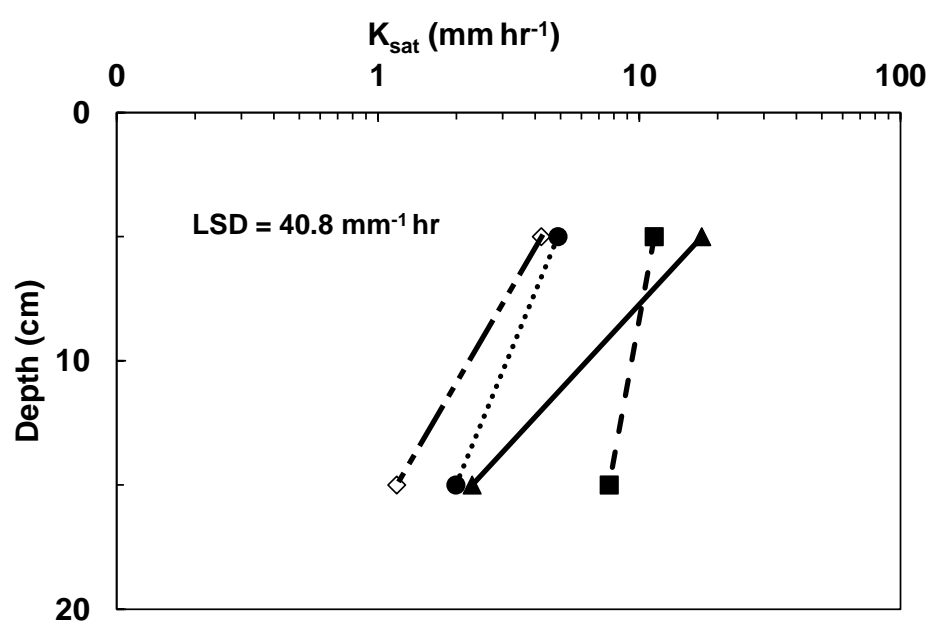


Figure 3.1 (a) soil bulk density two weeks after cover crop termination (b) soil bulk density one week before cover crop termination (c) saturated hydraulic conductivity $\left(K_{\text {sat }}\right)$ two weeks after cover crop termination and (d) $K_{\text {sat }}$ one week before cover crop termination at various depths as influenced by cover crop with tillage (CC-Till), no cover crop with tillage (NC-Till), cover crop with no till (CC-NT), and no cover crop with no till (NC-NT) managements. Note: (a) Bar indicates least significant difference (0.05) value for bulk density. (b) The least significant difference (LSD) (0.05) value for Ksat is listed on the graph due to log scale. 
(a)

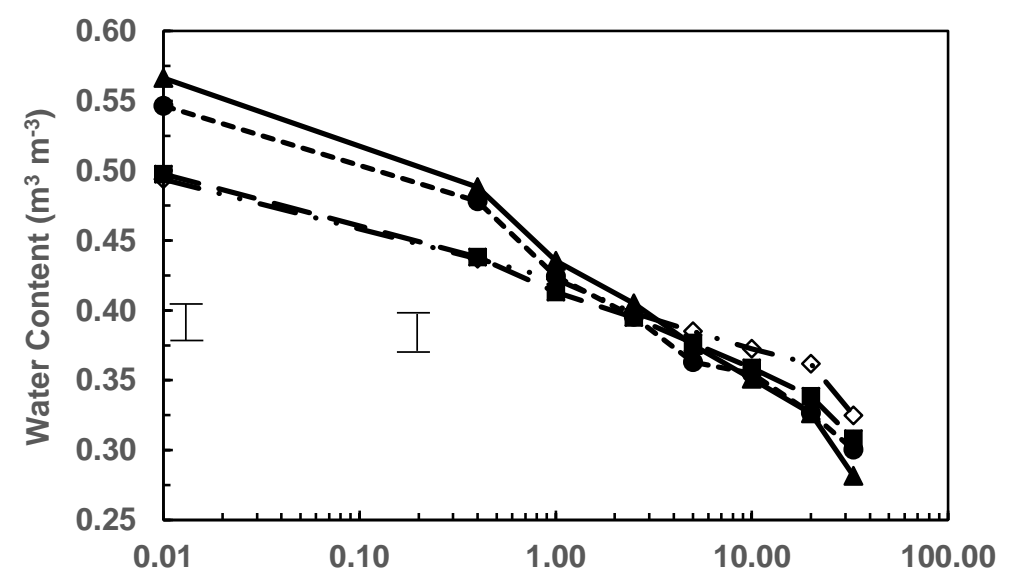

(c)

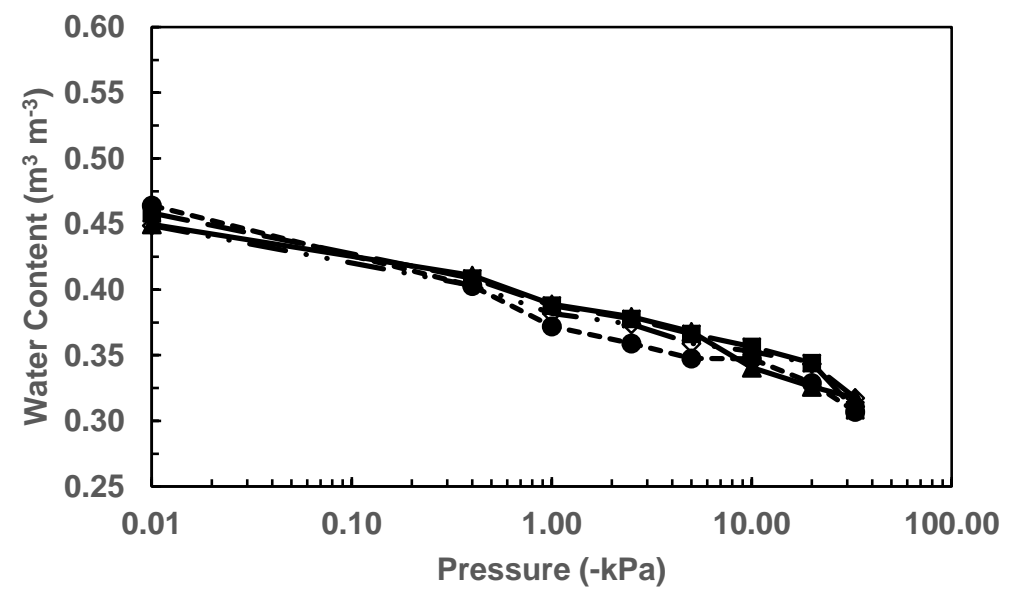

(b)

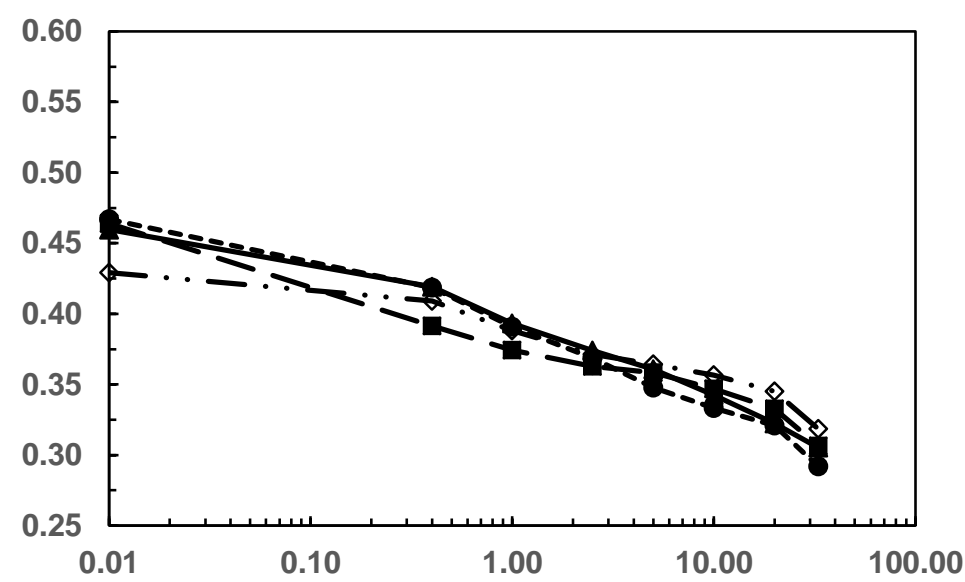

(d)

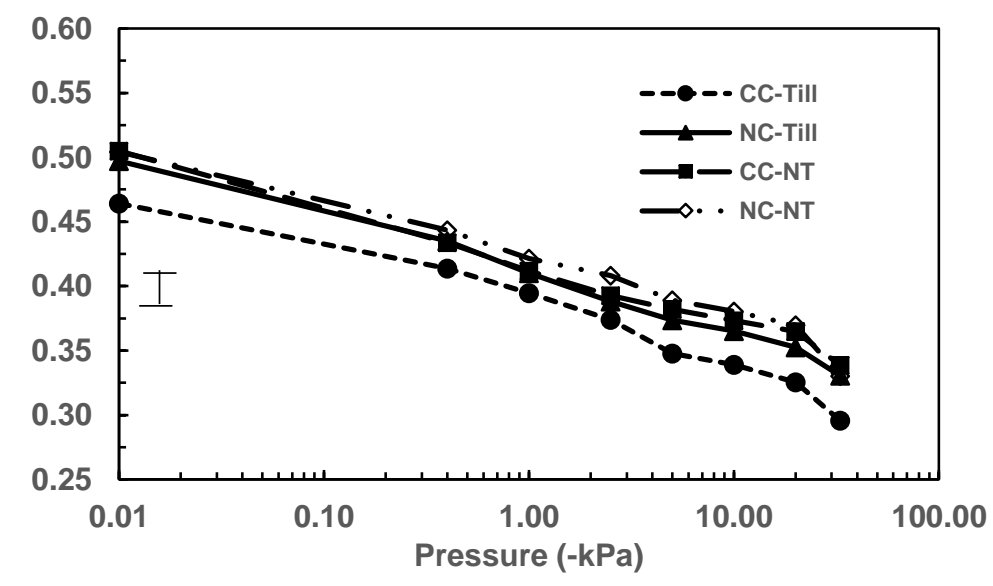

Figure 3.2 Soil water retention curves at (a) 0 to $10 \mathrm{~cm}$ (b) 10 to $20 \mathrm{~cm}$ (c) $20-30 \mathrm{~cm}$ (d) 30 to $40 \mathrm{~cm}$ depths as influenced by cover crop with tillage (CC-Till), no cover crop with tillage (NC-Till), cover crop with no till (CC-NT), and no cover crop with no till (NC-NT) treatments two weeks after cover crop termination. Note: Bar indicates least significant difference $(0.05)$ value for water retention. 
(a)

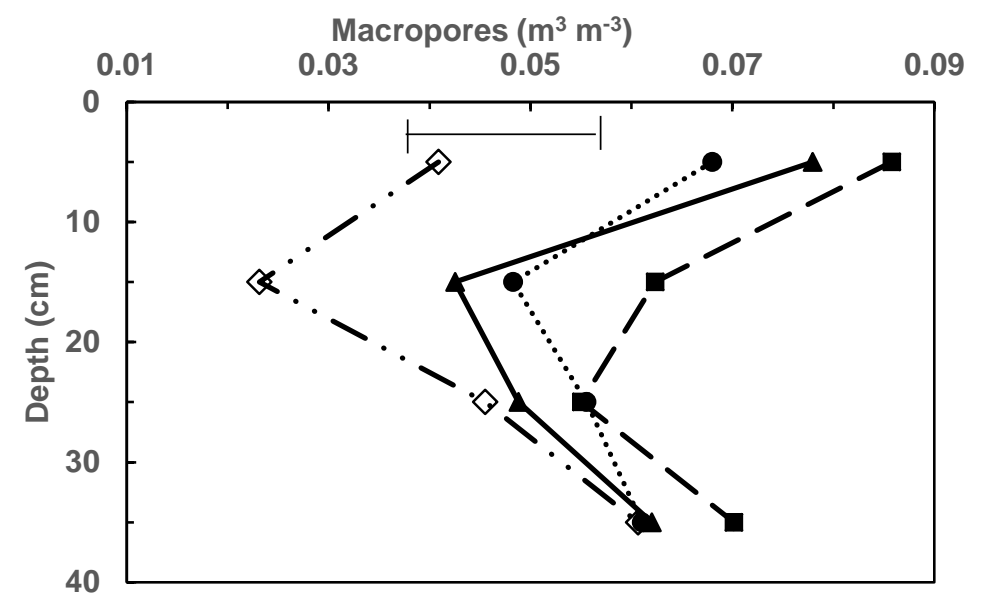

(c)

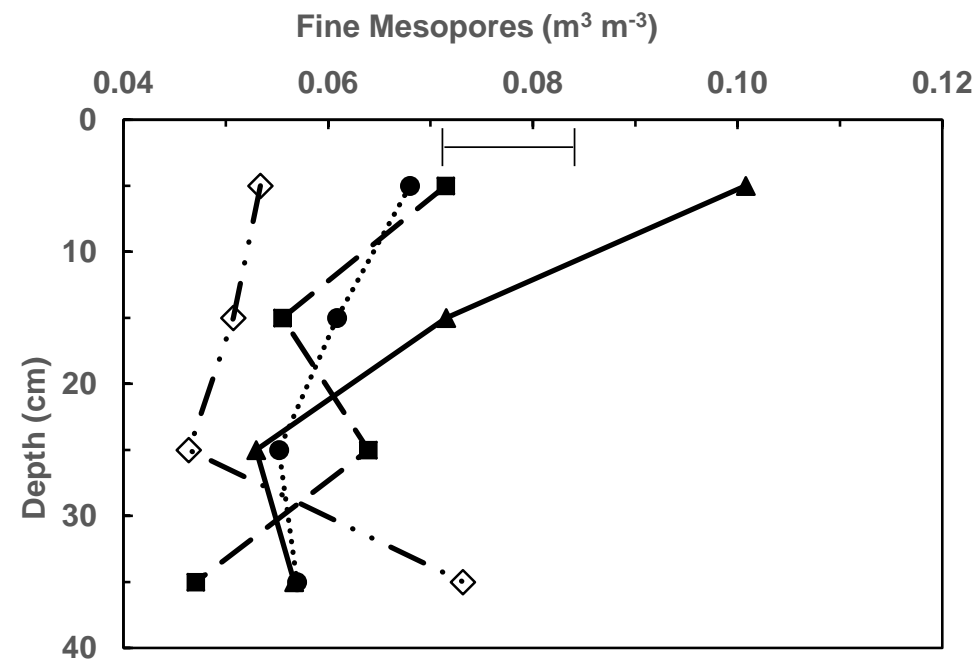

(b)

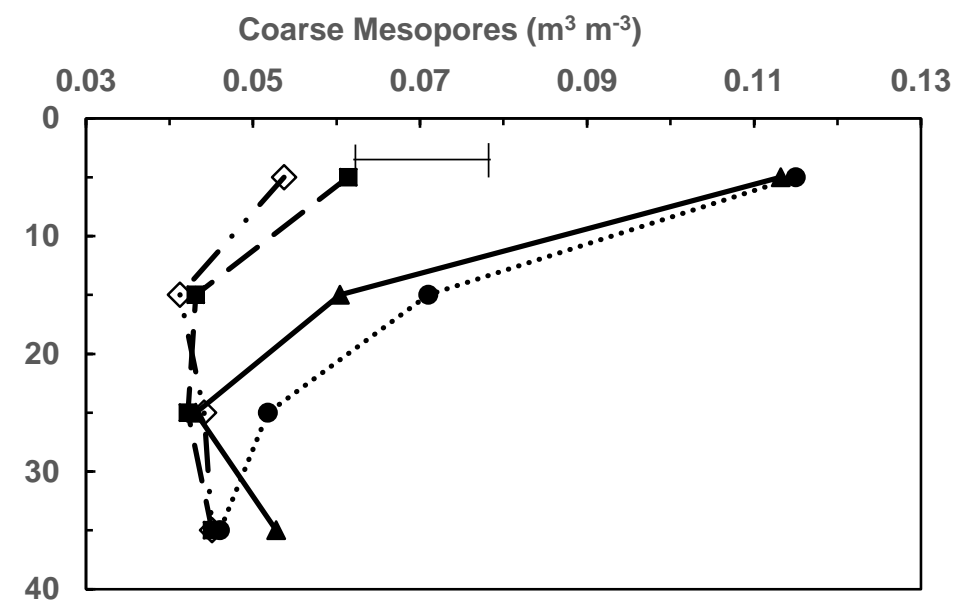

(d)

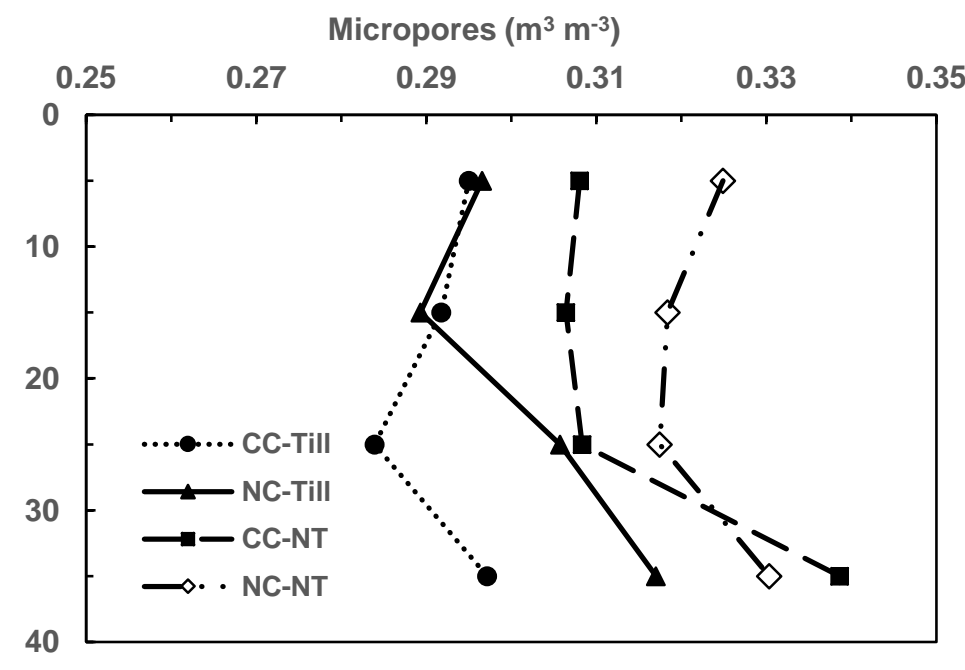

(e) 


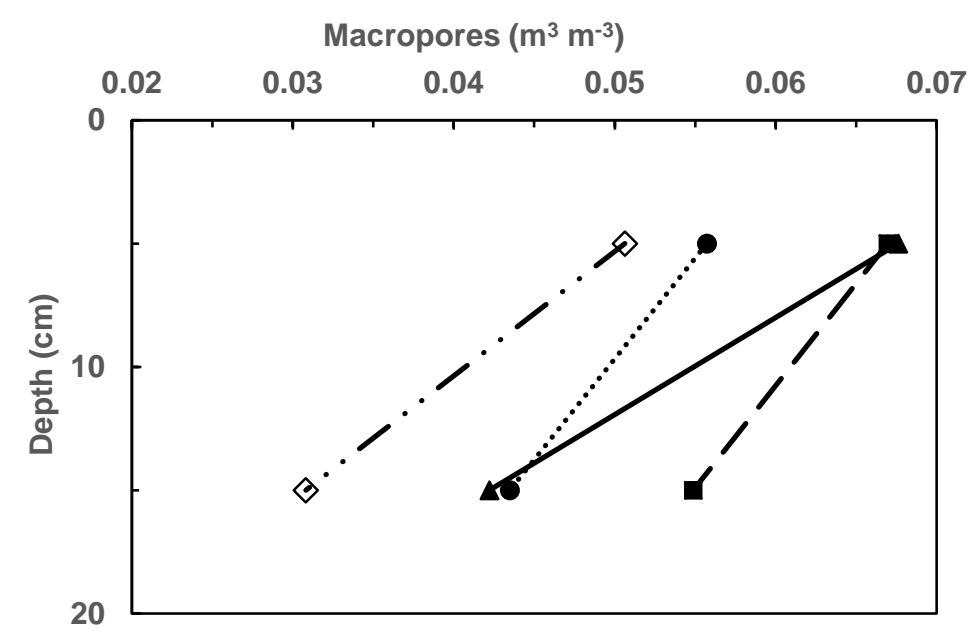

(g)

$\bowtie$

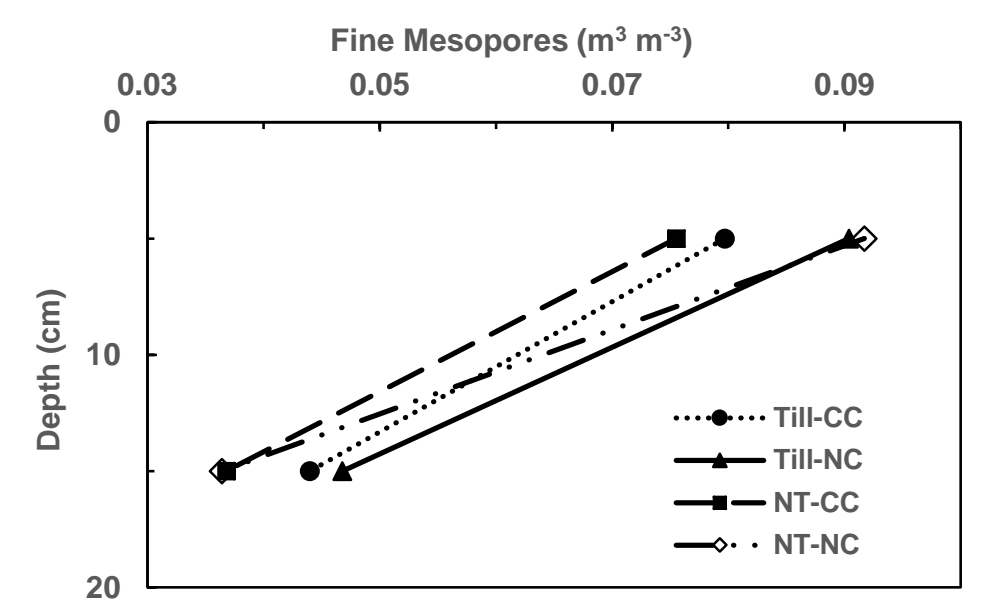

Coarse Mesopores $\left(\mathrm{m}^{3} \mathrm{~m}^{-3}\right)$

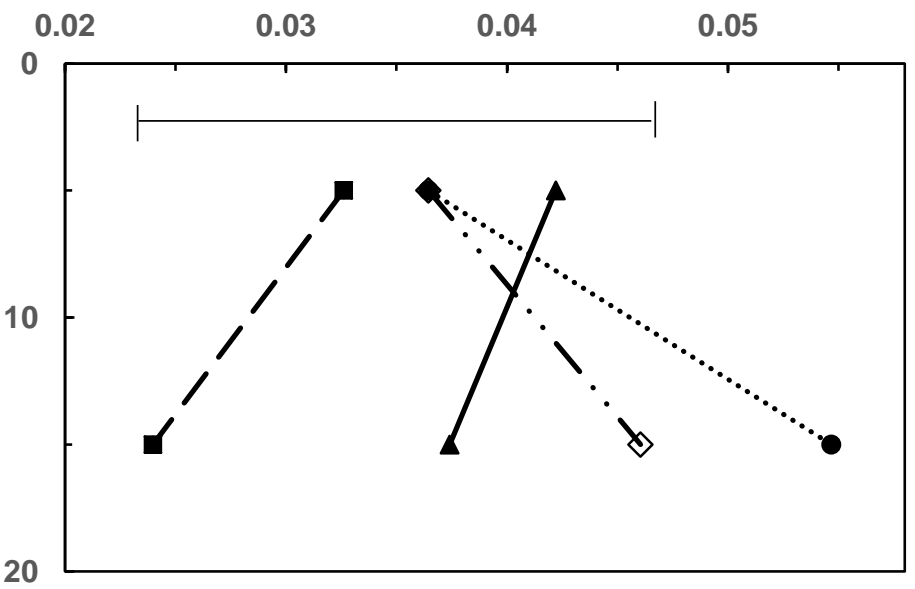

(h)

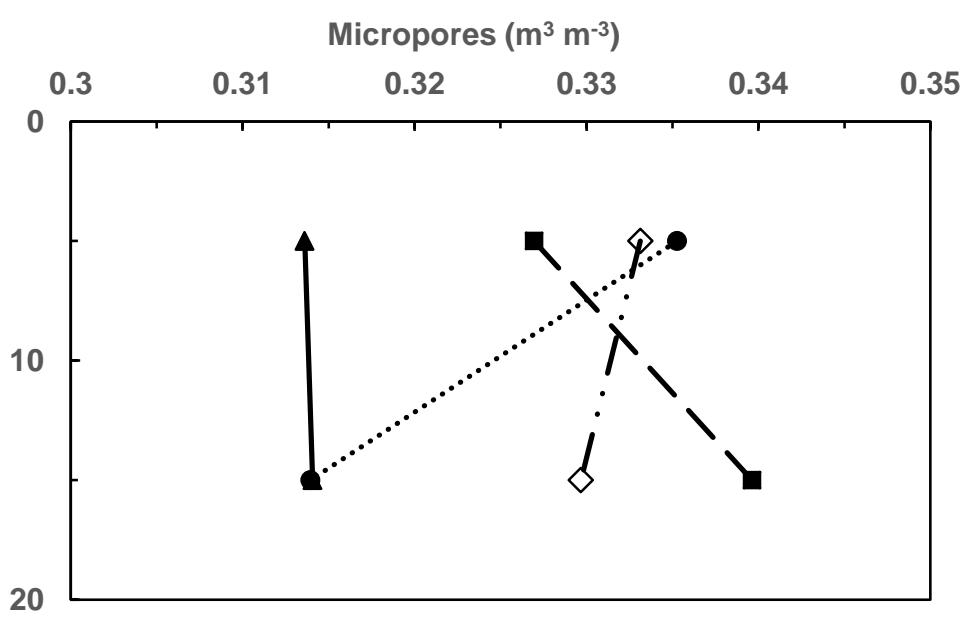

Figure 3.3 Pore size distributions at various depths; (a-d) two weeks after cover crop termination (e-h) one week before cover crop termination as influenced by cover crop with tillage (CC-Till), no cover crop with tillage (NC-Till), cover crop with no till (CC-NT), and no cover crop with no till (NC-NT) treatments. Note: Pore size classes include; macropores (> $1000 \mu \mathrm{m}$ diameter), coarse mesopores $(60-1000 \mu \mathrm{m})$, fine mesopores $(10-60 \mu \mathrm{m}$ diameter), micropores $(<10 \mu \mathrm{m}$ diameter). Bar indicates least significant difference $(0.05)$ value for pore size distribution. 


\title{
CHAPTER 4
}

\section{IN SITU INFILTRATION AS AFFECTED BY COVER CROP AND TILLAGE MANAGEMENT}

\begin{abstract}
Water is usually the most limiting factor in agricultural grain crop production. Various agricultural management practices such as tillage and use of cover crops have the potential to influence water infiltration into soil. This study was conducted on a Waldron silt loam (fine, smectictic, calcareous, mesic Aeric Fluvaquents) soil to evaluate the influence of cover crop and tillage management on in situ infiltration. The field site included three replicate blocks in a randomized complete block design with each plot measuring $21.3 \mathrm{~m}(69.9 \mathrm{ft})$ length and $12.2 \mathrm{~m}(40.0 \mathrm{ft})$ width. The two treatment factors included cover crop at two levels (cereal rye [Secale cereal L.] cover crop vs. no cover crop) and tillage at two levels (moldboard plow tillage vs. no till). Continuous corn (Zea mays L.) was grown. Infiltration rates were measured in all the treatments using a Mariotte system with single ring infiltrometers during the 2014 and 2015 growing seasons. Water infiltration parameters were estimated using the Parlange and Green-Ampt infiltration equations. Parlange and Green-Ampt models appeared to fit measured data well with coefficient of variation ranging from 0.92 to 0.99 . Results also showed that in 2014 , the Parlange model saturated hydraulic conductivity $\left(K_{S}\right)$ parameter value for no-till (NT) was $30.4 \mathrm{~mm} \mathrm{~h}^{-1}$, about $42 \%$ greater than till. The Green-Ampt $K_{S}$ parameter value for NT was $25.9 \mathrm{~mm} \mathrm{~h}^{-1}$, about $54 \%$ greater than till. In 2015, the Parlange model sorptivity $(S)$
\end{abstract}


parameter value for cover crops (CC) was $38.6 \mathrm{~mm} \mathrm{~h}^{-0.5}$, about $82 \%$ greater than no cover crop (NC). The Green-Ampt model $S$ parameter value for CC was $34.0 \mathrm{~mm} \mathrm{~h}^{-0.5}$, about $90 \%$ greater than NC. Cover crop management can increase water infiltration which can improve soil quality and enhance the sustainability of crop production systems.

Key words: Green-Ampt equation - Parlange equation - ponded infiltration - quasi-steady infiltration rate - saturated hydraulic conductivity - sorptivity. 


\section{INTROUCTION}

Soil water conservation and runoff reduction and control are essential for improved agricultural productivity and environmental sustainability. Rain occurring on the soil surface can either infiltrate into the soil or pond on the surface and potentially runoff. A combination of these processes can also occur, especially if the rate of rainfall is high. In order to identify water conservation strategies and runoff and erosion control, knowledge of water infiltration into soil is essential (Shukla et al., 2003).

Infiltration involves the entry of water through the air-soil interface into the vadoze zone. Infiltration is affected by several soil properties including soil structure, texture, soil organic matter, soil cover, antecedent soil water content, and landscape position. Some of these properties can be influenced by management systems such as tillage and use of cover crops (Radke and Berry, 1993; Shukla, 2014). Infiltration may be a good indicator of changes in soil physical properties.

Cover crops are grown for various reasons, especially for their ability to protect and condition the soil during periods when the soil is left bare (Troeh et al., 2004). Cover crops influence infiltration by reducing soil bulk density (Villamil et al., 2006; Blanco-Canqui et al., 2011) and improving macroporosity (Auler et al., 2014). In a study by Kemper and Derpsch (1981) on two soils (Oxisols and Alfisols), cover crops were found to increase the infiltration rate by $416 \%$ into an Oxisol and by about $629 \%$ into an Alfisol compared to no cover crop. They attributed this increase in infiltration rate to the bio-pores formed by the cover crop roots. Wilson et al. (1982) reported an increase in macro-pores and infiltration rate with the use of cover crops compared with no cover crop on an eroded Alfisol in 
southern Nigeria. More recently, Joyce et al. (2002) reported improved rainfall infiltration in cover crop management compared with a fallow rotation.

Cover crops can also influence infiltration indirectly by improving soil structure. Several researchers (e.g. Sainju et al., 2002; Villamil et al., 2006) have reported higher organic matter content when cover crop roots decompose and when their above ground biomass is incorporated into the soil. Organic matter increases can improve soil structure and water infiltration. The leaves of cover crops can also intercept raindrops, reduce their kinetic energy and reduce splash detachment. Haramoto and Gallandt, (2004) reported that Brassicas (Brassica juncea L.) can provide more than $80 \%$ soil coverage when used as a winter cover crop. This higher surface cover can improve agricultural sustainability after a few decades.

Besides cover crops, producers also use tillage management as a means of seedbed preparation and fertilizer incorporation. The process of tilling the soil can induce changes in soil structure, which can influence infiltration into the soil. Lipeic et al. (2006) studied the effect of long-term tillage on water infiltration. They reported that deep plowing to a depth of $200 \mathrm{~mm}(8 \mathrm{in})$ significantly increased the cumulative infiltration rate by $62 \%$ compared with shallow tillage (50 $\mathrm{mm}$ [2 in] deep) and by $61 \%$ compared with no tillage. They attributed this to the higher proportion of flow-active pores induced by deep tillage. Similar results were reported by Pikul et al. (1996). However, Lal and Vandoren (1990) did not find any significant differences in infiltration rate between tillage and no till management. They attributed the maintenance of infiltration rate in no-till management to the development of continuous biopores and worm channels. Pikul and Zuzel (1994) and Capoweiz et al. (2009) reported similar findings. The contrast in these studies may have 
resulted from the fact that the benefits of tillage in improving macropores at the tilled depth are not usually sustained over time (Haruna et al., 2017).

Reduced infiltration can hinder underground water recharge and this can have negative consequences on agricultural productivity (Connolly et al., 1997). Water infiltration is therefore important for improved agricultural productivity necessitated by the current global human population increase (Reicosky et al., 2011). Several researchers (e.g. Singh and Woolhiser, 2002; Jury and Horton, 2004; Liu et al., 2008) have used physically based models as a means of better understanding infiltration and water distribution in the soil. Physically based hydrologic models (e.g. Green and Ampt, 1911; Parlange et al., 1981) fit infiltration data over time with physical parameters: saturated hydraulic conductivity $\left(K_{s}\right)$ and sorptivity $(S)$. The $K_{s}$ parameter has been defined as the maximum water flow, in a completely saturated soil, due to gravity alone, while the $S$ parameter is the ability of the soil to conduct water by capillarity and this varies with initial water content (Touma et al., 2007). Both parameters can reflect the changes in soil properties caused by various management practices that could influence cumulative infiltration.

Northern Missouri is an agriculturally intensive region with management practices that reflect those applied throughout the Midwestern United States, the 'breadbasket' region of the country. It is therefore important to understand the individual and combined influence of these practices on in situ infiltration. The specific objective of this study was to evaluate the influence of cover crop and tillage management practices on water infiltration parameters. 


\section{MATERIALS AND METHODS}

\section{Site Description}

Lincoln University's Freeman Farm was used for this study which is located about $8 \mathrm{~km}$ (5 miles) north-east of Jefferson City, Missouri, USA (38 $\left.58^{\prime} 16^{\prime \prime} \mathrm{N}, 92^{\circ} 10^{\prime} 53^{\prime \prime} \mathrm{W}\right)$. The soil was classified as Waldron silt loam (fine, smectictic, calcareous, mesic Aeric Fluvaquents) by the USDA. Table 4.1 shows selected physical and chemical properties of the soil. The field site is located about $166 \mathrm{~m}$ (506 ft) above sea level, with a 2\% slope. For 50 yrs prior to the establishment of this research in 2010, the study site was in a corn (Zea mays L.) and soybean (Glycine $\max \mathrm{L}$.) rotation with a moldboard plow tillage to a depth of $150 \mathrm{~mm}$ (6 in). For this study, the field site was set up using a randomized complete block design with treatments that included tillage (moldboard plow) at two levels (tillage vs no tillage) and cereal rye cover crop (Secale cereal L.) at two levels (cover crop vs. no cover crop), with three replicates.

The main crop grown on the field site was corn, planted in late April or early May, depending on weather variability, and harvested in September or October of each growing season. The cover crop was planted by broadcasting in late October or early November of each year, after harvesting corn. The cover crops were allowed to grow during winter and spring months and terminated in April using glyphosate ( $N$-[phosphonomethyl] glycine) prior to tillage and planting of corn. For the tillage plots, the soil was moldboard-plowed to a depth of $150 \mathrm{~mm}$ (6 in). This was done in late April or early May of each agricultural season. All corn plots received $26 \mathrm{~kg} \mathrm{ha}^{-1}\left(23 \mathrm{lbs} \mathrm{ac}^{-1}\right) \mathrm{N}, 67 \mathrm{~kg} \mathrm{ha}^{-1}\left(60 \mathrm{lbs} \mathrm{ac}^{-1}\right) \mathrm{P}_{2} \mathrm{O}_{5}$, and

$67 \mathrm{~kg} \mathrm{ha}^{-1}\left(60 \mathrm{lbs} \mathrm{ac}^{-1}\right) \mathrm{K}_{2} \mathrm{O}$. However, an additional $202 \mathrm{~kg} \mathrm{ha}^{-1}\left(180 \mathrm{lbs} \mathrm{ac}^{-1}\right) \mathrm{N}$ was applied from urea (Kladivko et al., 2014; Haruna and Nkongolo, 2015). 
The 50-year annual average temperature for the study site is $13{ }^{\circ} \mathrm{C}\left(55^{\circ} \mathrm{F}\right)$ with January $\left(-6^{\circ} \mathrm{C}\left[21^{\circ} \mathrm{F}\right]\right)$ being the coldest and July $\left(31^{\circ} \mathrm{C}\left[88^{\circ} \mathrm{F}\right]\right)$ being the warmest months. Average temperature in July 2014 was $23{ }^{\circ} \mathrm{C}\left(74{ }^{\circ} \mathrm{F}\right)$, while the average temperature in July 2015 was $25^{\circ} \mathrm{C}\left(78^{\circ} \mathrm{F}\right)$. The 50 -year average annual precipitation for the area is $1095 \mathrm{~mm}$ (43 in) with January (48 $\mathrm{mm}$ [2 in]) being the driest and May (131 $\mathrm{mm}$ [5 in]) being the wettest months. The total precipitation in July 2014 was $68 \mathrm{~mm}$ (3 in) while the total precipitation in July 2015 was $153 \mathrm{~mm}$ (6 in) (NOAA, 2016).

\section{Ponded Infiltration Measurements}

For this study, ponded infiltration was measured once in each of the three replicates with the following treatments; cover crop with tillage (CC-Till), cover crop with no tillage (CC-NT), no cover crop with tillage (NC-Till) and no cover crop with no tillage (NC-NT). Each plot measured $12.2 \times 21.3 \mathrm{~m}(40 \times 70 \mathrm{ft})$. Three infiltration measurements were also taken from a non-treated area in perennial fescue grass (festuca arundinacea), adjacent to the field, for comparison purposes only. A total of 15 measurements were made each year (4 treatments x 3 replicates + 3 perennial grass); in early July of 2014 and 2015 . Measurements were made in the middle of each plot, in non-trafficked mid-row crop areas (Kladivko et al., 2014).

Infiltration rates were measured using single-ring infiltrometer units (Bouwer, 1986). The steel rings have an inside diameter of $250 \mathrm{~mm}$ (10 in), a length of $300 \mathrm{~mm}$ (12 in) and a wall thickness of $3 \mathrm{~mm}(0.1 \mathrm{in})$. The rings were inserted vertically into the soil by manually driving the ring into the soil to a depth of about $150 \mathrm{~mm}$ (6 in). At the time of measurement, soil samples were taken from areas around the ring at depths of 0 to $100 \mathrm{~mm}$ (0 to 4 in) and 100 to $200 \mathrm{~mm}$ (4 to 8 in) using a soil probe for antecedent volumetric soil 
water content determination. These samples were taken about $2 \mathrm{~m}$ from the infiltration ring to prevent bypass flow of the infiltrating water into these holes.

For the ponded infiltration measurements, a $50 \mathrm{~mm}$ ( 2 in) head was maintained inside the ring using a Mariotte system. Infiltration measurements were conducted for about 120 mins. Two infiltration models were used to fit the measured infiltration data; Green and Ampt (1911) and Parlange et al. (1982) (henceforth referred to as Green-Ampt and Parlange models respectively). The Green-Ampt and Parlange models provide the best infiltration data fit and confidence intervals for a two-parameter model (Clausnitzer et al., 1998). The Green-Ampt (1911) infiltration model was modified by Philip (1957a) for time (t) versus cumulative infiltration (I), as follows:

$$
t=\frac{I}{K_{s}}-\frac{\left[S^{2} \ln \left(1+\frac{2 I K_{s}}{S^{2}}\right)\right]}{2 K_{S}^{2}}
$$

where $t(\mathrm{~T})$ is time $(\mathrm{hr}), I(\mathrm{~L})$ is the cumulative infiltration $(\mathrm{mm}), S\left(\mathrm{~L} \mathrm{~T}^{-0.5}\right)$ is the sorptivity $\left(\mathrm{mm} \mathrm{hr}^{-0.5}\right)$ and $K_{S}\left(\mathrm{~L} \mathrm{~T}^{-1}\right)$ is the saturated hydraulic conductivity $\left(\mathrm{mm} \mathrm{hr}^{-1}\right)$.

Modified from Talsma and Parlange (1972), the physically based Parlange model for $t$ versus $I$ is as follows:

$$
t=\frac{I}{K_{S}}-\frac{S^{2}\left[1-\exp \left(-\frac{2 I K_{S}}{S^{2}}\right)\right]}{2 K_{S}^{2}}
$$

The $S$ and $K_{S}$ parameters for the Green-Ampt and Parlange models were estimated based on cumulative infiltration using methods proposed by Clothier and Scotter (2002). A nonlinear fitting procedure was used to fit measured $I$ vs $t$ data to the Green-Ampt (eqn 1 ) and 
Parlange (egn. 2) models. The initial parameter values represent the initial starting value for the non-linear curve fitting procedure. The measured infiltration data was fitted to the models by determining the volume of water infiltrated. Volume of water infiltrated was determined by multiplying the volume of the infiltrometer by the volume of the water delivery tube. Depth of water infiltration $\left(D_{i}\right)(\mathrm{mm})$ was then calculated by the following relationship;

$$
D_{i}=\left(\frac{V_{i}}{A_{i}}\right) \times 10
$$

where $V_{i}$ is the volume of water infiltrated $\left(\mathrm{cm}^{3}\right)$ and $A_{i}$ is the area of the steel infiltration ring $\left(\mathrm{cm}^{2}\right)$. The next step was to calculate the rate of infiltration $\left(R_{i}\right)\left(\mathrm{mm} \mathrm{hr}^{-1}\right)$. This was calculated using the following relationship;

$$
R_{i}=\frac{D_{i} t_{1}-D_{i} t_{0}}{t_{1}-t_{0}}
$$

where $D_{i} t_{1}$ is the depth of infiltration at the next infiltration time (after the initial infiltration time), $D_{i} t_{0}$ is the depth of infiltration at the initial infiltration time, $t_{1}$ is the next infiltration time, and $t_{0}$ is the initial infiltration time. The initial $S$ parameter was estimated by dividing the initial infiltration by time $(\mathrm{t})^{0.5}$, while the initial $K_{\mathrm{S}}$ parameter value was the steady infiltration rate $\left(\mathrm{mm} \mathrm{h}^{-1}\right)$.

Fitted parameters that suitably describe data can be used for predictive purposes (Hopmans et al., 1997). The $S$ parameter is highly dependent on initial infiltration rate and the initial infiltration rate depends on the antecedent soil water content. Therefore, the $S$ parameter is dependent on the antecedent soil water content. The Green-Ampt and 
Parlange models can be used to evaluate the consistency in estimated physical parameters of $S$ and $K_{S}$.

Field saturated hydraulic conductivity $\left(K_{f s}\right)$ was estimated using the method of Reynolds et al. (2002). Assuming a one dimensional flow in the infiltration ring and a divergent three-dimensional flow below the ring, Reynolds et al. (2002) uses the following equation:

$$
K_{f S}=\frac{q_{s}}{\left(\frac{H}{C_{1} d+C_{2} a}\right)+\left\{\frac{1}{\left[\alpha^{*}\left(C_{1} d+C_{2} a\right)\right]}\right\}+1}
$$

where $K_{f s}$ is the field-saturated hydraulic conductivity $\left(\mathrm{mm} \mathrm{hr}^{-1}\right), q_{s}$ is the quasi-steady infiltration rate $\left(\mathrm{mm} \mathrm{hr}^{-1}\right), a$ is the radius of the infiltration ring $(\mathrm{mm}), H$ is the hydraulic head of ponded water in the ring $(\mathrm{mm}), d$ is the depth of ring insertion into the soil $(\mathrm{mm})$, $C_{1}$ and $C_{2}$ are dimensionless constants $\left(C_{1}=0.993\right.$ and $C_{2}=0.578$ for this infiltrometer $)$, and $\alpha^{*}$ is the soil macroscopic capillary length (Reynolds et al. 2002) estimated from the water retention data. (The soil macroscopic capillary length was obtained from Haruna et al. (2017) fitted to the van Genuchten equation [van Genuchten, 1980; Lu et al. 2008]). The $\alpha^{*}$ values used were $0.026,0.005,0.031$ and $0.002 \mathrm{~mm}^{-1}(0.066,0.127,0.787$ and 0.0508 $i^{-1}$ ) for CC-Till, CC-NT, NC-Till and NC-NT treatments respectively. The fitted $\alpha^{*}$ parameters used represented 0 to $100 \mathrm{~mm}$ ( 0 to $4 \mathrm{in}$ ) depth for each treatment. Saturated hydraulic conductivity $\left(K_{\text {sat }}\right)$ values were obtained from soil core data (Haruna et al., 2017), for comparison with field estimated $K_{f s}$ values.

An important distinction exists between two types of saturated hydraulic conductivities $\left(\mathrm{K}_{S}\right.$ and $\left.K_{\text {sat }}\right)$ as used in the current study. The saturated hydraulic 
conductivity parameter estimated from both models (Parlange and Green-Ampt) is denoted as $K_{S}$. The saturated hydraulic conductivity measured on soil cores in the laboratory (extracted from Haruna et al., 2017) is denoted as $K_{\text {sat }}$.

\section{Statistical Analysis}

Analysis of variance (ANOVA) was conducted using the SAS statistical software (SAS institute 2013) using the general linear model (GLM) procedure. Single degree of freedom contrasts for the treatment (tillage and cover crop) effects were divided into 'no till vs. tillage (NT vs. Till)' and 'cover crop vs. no cover crop (CC vs. NC)' and 'tillage*cover crop interaction (Till*CC)'. Statistical differences were declared to exist at $\mathrm{p} \leq 0.05$ probability level.

\section{RESULTS AND DISCUSSION}

\section{Ponded Infiltration Measurements}

After infiltration measurements were conducted in the field, two infiltration models (Parlange and Green-Ampt) were fitted to the measured cumulative infiltration data as a function of time. Typical replicates for the cover crop with tillage (CC-Till), cover crop with no tillage (CC-NT), no cover crop with tillage (NC-Till) and no cover crop with no tillage (NC-NT) treatments are shown in fig. 4.1. These figures illustrate the rapid initial increase in cumulative infiltration at early times and the more constant increase in cumulative infiltration near 1.5 to 2 hours after initiating infiltration.

The models fit the data well with coefficients of variation $\left(\mathrm{r}^{2}\right)$ greater than 0.92 , and most of the coefficients near 0.99. Both models (Parlange and Green-Ampt) appeared to fit the measured data well. 


\section{Bulk density $(\mathrm{Db})$ and antecedent volumetric water content (VWC)}

Results for bulk density and antecedent soil water content are shown in table 4.2. There were no significant differences between cover crop and tillage managements for these properties. However, bulk density at the 100 to $200 \mathrm{~mm}$ (4 to $8 \mathrm{in}$ ) depth was $1.26 \mathrm{~g}$ $\mathrm{cm}^{-3}$, about $27 \%$ greater than that at the 0 to $100 \mathrm{~mm}$ ( 0 to 4 in) depth.

Averaged across tillage in 2014 and 2015, volumetric water content (VWC) tended to be lower in $\mathrm{CC}$ compared to $\mathrm{NC}$ management. Cover crops have been reported to increase evapotranspiration from the soil (Dabney et al., 2001). This may be the reason for the lower water content in cover crop plots. In 2014, VWC was very similar between tillage and no-till (NT) management. In 2015, however, VWC tended to be lower in tillage compared with NT management (table 4.2). One possible reason for the lower water content in tillage compared to NT plots in 2015 could be an increased soil water evaporation caused by soil tillage.

\section{Sorptivity (S) Parameter}

The geometric means of the $S$ parameter values estimated using both models (Parlange and Green-Ampt) were significantly affected by treatments in $2015(\mathrm{p}<0.05)$ (table 4.3). In 2015, the cover crop vs. no cover crop contrast (CC vs. NC) was significant for the $S$ parameter in each model. The Parlange $S$ parameter for CC was $38.6 \mathrm{~mm} \mathrm{~h}^{-0.5}$, about $82 \%$ greater than that for NC, while the Green-Ampt $S$ parameter for CC was 34.0 $\mathrm{mm} \mathrm{h}^{-0.5}$, about $90 \%$ greater than that for NC (table 4.3). Although differences were not significant for this contrast in 2014 , the $S$ parameter estimated from both models tended to be greater for $\mathrm{CC}$ compared to $\mathrm{NC}$ management. 
Sorptivity is highly dependent on antecedent soil water content. The higher $S$ parameter values in cover crop management compared to no cover crop management (averaged across tillage) in 2014 (Parlange: $\mathrm{CC}=36.3 \mathrm{~mm} \mathrm{~h}^{-0.5}, \mathrm{NC}=20.0 \mathrm{~mm} \mathrm{~h}^{-0.5}$; Green-Ampt: $\mathrm{CC}=29.1 \mathrm{~mm} \mathrm{~h}^{-0.5}, \mathrm{NC}=19.4 \mathrm{~mm} \mathrm{~h}^{-0.5}$ ) and 2015 (Parlange: $\mathrm{CC}=38.6 \mathrm{~mm}$ $\mathrm{h}^{-0.5}, \mathrm{NC}=7.04 \mathrm{~mm} \mathrm{~h}^{-0.5}$; Green-Ampt: $\mathrm{CC}=34.0 \mathrm{~mm} \mathrm{~h}^{-0.5}, \mathrm{NC}=3.56 \mathrm{~mm} \mathrm{~h}^{-0.5}$ ) appeared to be a function of lower antecedent soil water content. This result shows the ability of cover crops to transpire water from the field as evidenced by the numerically lower antecedent volumetric water content in these plots (averaged across tillage) (table 4.2). The cover crop's ability to reduce near-surface soil water content through transpiration can be important in very wet early growing seasons as cover crops may help increase the growing season of the cash crop by removing soil water from the field. The differences in soil water content between cover crop and no cover crop management may not be significant enough to reduce crop productivity, even in a drier growing season as reported by Daigh et al. (2014). In fact, Daigh et al. (2014) reported that in a drought year, cover crops probably enhanced infiltration and maintained better soil water content compared with no cover crop. Despite the near-surface soil water transpiration by cover crops, Sims (1989) and Gardner (1992) suggested that cash crop yield can be maintained or improved through appropriate specie selection and proper termination timing of cover crops.

Tillage may be performed for various reasons, one of which is seedbed preparation. When used as a means of seedbed preparation, tillage may help aerate the soil, thus drying it up in wet seasons, as evidenced in the numerically higher $S$ parameter value estimated from both models in 2014 (this result was not consistent over both years of the study). Sorptivity is related to the variables or parameters controlling the hydraulic conductivity 
of porous materials. These variables include grain size distribution and porosity of the porous medium as well as viscosity, density and relative permeability of the infiltrating liquid (Schulte et al., 2007). Therefore, sorptivity can be viewed as a property that can affect the ability of a porous material to absorb or desorb water in zones and regions affected by capillarity, like the vadoze zone.

\section{Saturated Hydraulic Conductivity (Ks) Parameter}

The geometric means of the $K_{S}$ parameter values estimated from the Parlange and Green-Ampt models were significantly affected by treatments in 2014 ( $\mathrm{p}<0.01)$ (table 4.3). In 2014, the cover crop vs. no cover crop (CC vs. NC) and no-till vs. tillage (NT vs. Till) contrasts were significant for the $K_{S}$ parameter in each model. The Parlange $K_{S}$ parameter for CC was $38.4 \mathrm{~mm} \mathrm{~h}^{-1}$, about $75 \%$ greater than that of NC. The Green-Ampt $K_{S}$ parameter for CC was $31.4 \mathrm{~mm} \mathrm{~h}^{-1}$, about $80 \%$ greater than that of NC. The Parlange $K_{S}$ parameter for NT was $30.4 \mathrm{~mm} \mathrm{~h}^{-1}$, about $42 \%$ greater than that of Till. Similarly, the Green-Ampt $K_{S}$ parameter for NT was $25.9 \mathrm{~mm} \mathrm{~h}^{-1}$, about $54 \%$ greater than that of Till (table 4.3).

In 2014, the quasi-steady infiltration rate and field saturated hydraulic conductivity parameter values estimated from infiltration measurements in perennial fescue grass were higher compared with the adjacent main treatments (cover crop and tillage). However, values were not significantly different between the perennial grass and cover crop treatments, although perennial grass had numerically higher values (Appendix A. 2.7). The trend for greater water infiltration in perennial grass systems compared with $\mathrm{CC}$ and tillage management practices is presumed to be as a result of the extensive roots of perennial grass systems and these roots may be present for several years. 
Studying the same site, Haruna et al. (2017) reported that cover crops had $30 \%$ more macropores compared to no cover crop management, averaged over two depths [0 to 100 and 100 to $200 \mathrm{~mm}$ ( 0 to 4 and 4 to 8 in)] two weeks after cover crop termination and spring tillage (150 $\mathrm{mm}$ [6 in] deep moldboard plow done in May; the same tillage practice for this study). This suggests that the macropores generated by cover crops may persist for some time. Haruna et al. (2017) also reported a trend of lower soil bulk density and higher saturated hydraulic conductivity (measured on cores in the laboratory) in CC compared to NC management. Cover crop roots have been reported to reduce soil bulk density (Villamil et al. 2006; Blanco-Canqui et al. 2011) and improve pore size distribution and pore connectivity (Villamil, 2006). When these roots die out, they can increase soil organic matter (Sainju et al. 2002; Villamil et al. 2006), thus increasing aggregate stability (Dapaah and Vyn, 1998). The leaves of cover crops can also provide soil cover (Haramoto and Gallandt, 2004) and reduce splash detachment and surface crusting (Folorunso et al. 1992). All these factors can potentially improve soil properties and may have accounted for increased infiltration in $\mathrm{CC}$ compared to $\mathrm{NC}$ found in the current study. Other researchers (e.g. McVay et al. 1989; Folorunso et al. 1992; Gulick et al. 1994; Joyce et al. 2002) have reported similar findings. The ability of cover crops to increase water infiltration can potentially lead to reduced water runoff and nutrient loss and increased grain crop productivity.

Haruna et al. (2017) also reported that tillage reduced soil bulk density by $10 \%$ and increased coarse mesopores (defined as soil pores with effective diameter of $60-1000 \mu \mathrm{m}$ ) by $80 \%$ (averaged over two depths [0 to 100 and 100 to $200 \mathrm{~mm} ; 0$ to 4 and 4 to $8 \mathrm{in}$ ] two weeks after cover crop termination and spring tillage). However, these improved soil 
properties are temporal and may not persist over time (Haruna et al. 2017). The lack of significant differences in infiltration between tillage and no-till management from the current study supports this fact, since infiltration studies were conducted about two months after tillage. Another reason for the lack of significant differences in infiltration between both tillage management practices could be because tillage can interrupt capillary pores and reduce pore connectivity (Azooz et al., 1996) both of which can reduce water infiltration. Lipiec et al. (2006) reported higher water infiltration in tillage compared to no-till management. In contrast, Abid and Lal (2005) reported that tillage reduced infiltration, partly due to a decrease in pore connectivity caused by tillage.

\section{Field Saturated Hydraulic Conductivity (Kfs) Parameter.}

In order to estimate the field-saturated hydraulic conductivity, the quasi-steady state infiltration rate $\left(q_{s}\right)$ was used. The quasi-steady state infiltration rate was affected by treatment in 2014 and by the CC vs. NC contrast in 2014 and (at p<0.06) in 2015 (table 4.4). In 2014, the $q_{s}$ parameter value for $\mathrm{CC}$ was $69.0 \mathrm{~mm} \mathrm{~h}^{-1}$, about $63 \%$ greater than that for NC. In 2015, the $q_{s}$ parameter value for CC was $47.5 \mathrm{~mm} \mathrm{~h}^{-1}$, about $48 \%$ greater than that for $\mathrm{NC}$.

The quasi-steady infiltration rate has been equated to the saturated hydraulic conductivity of the surface layer when infiltration takes place (Philip, 1957b). More recently, the $q_{s}$ parameter was related to the point, during water infiltration, when the volume of water entering the soil at fixed time intervals becomes constant (Amoozegar, 2004). Arriaga et al. (2010) stated that the quasi-steady infiltration rate is assumed to be achieved when the slope of the cumulative infiltration at two infiltration times is within 5\% 
of each other. It is therefore presumed that a higher $q_{s}$ parameter value means higher cumulative infiltration.

The field saturated hydraulic conductivity $\left(K_{f s}\right)$ parameter was affected by treatment and by the CC vs. NC contrast in 2014. In 2015, the $K_{f s}$ parameter was affected (at p<0.06) by the CC vs. NC contrast (table 4.4). In 2014, the $K_{f s}$ parameter value for CC was 27.8 $\mathrm{mm} \mathrm{h}^{-1}$, about $63 \%$ greater than that for NC. In 2015, the $K_{f s}$ parameter value was $38.3 \mathrm{~mm}$ $\mathrm{h}^{-1}$, about $48 \%$ greater than that for NC. This suggests that the inclusion of cover crops in crop production may enhance the performance of tillage in improving some infiltration parameters.

\section{Correlation between Kfs and Ksat.}

In order to evaluate the consistency of the parameters obtained from the field infiltration data with the laboratory measured data (Haruna et al., 2017), comparisons were made between the $K_{f s}$ parameter and the saturated hydraulic conductivity $\left(K_{s a t}\right)$ data measured previously in the laboratory. These $K_{\text {sat }}$ data were measured in 2014 at the 0 to $100 \mathrm{~mm}$ (0 to 4 in) depth and extracted from Haruna et al. (2017). These $K_{\text {sat }}$ data were correlated with the $K_{f s}$ estimated parameter values from 2014. The correlation coefficient for the regression between $K_{f s}$ and $K_{s a t}$ was found to be 0.48 . The slope of the regression was estimated to be 0.37 (Apendix A2.13). The $K_{f s}$ parameter value could be estimated as $0.5^{*} K_{\text {sat }}$ (Bouwer, 1986) and $0.67 * K_{\text {sat }}$ (Rachman et al. 2004). In the current study, this coefficient is estimated to be $0.4^{*} K_{s a t}$, which is slightly lower than the other two studies but similar to the one proposed by Kumar et al. (2012). By reducing or eliminating the diverging and horizontal flow through macropores, laboratory measured $K_{\text {sat }}$ can better relate to the $K_{f s}$ (Rachman et al., 2004). 


\section{SUMMARY AND CONCLUSIONS}

Single-ring infiltrometers were used to measure ponded infiltration into cover crop (CC) and tilled plots once in 2014 and once in 2015. In 2014, the Parlange model $K_{S}$ parameter value for $\mathrm{CC}$ was $38.416 \mathrm{~mm} \mathrm{~h}^{-1}$, about $75 \%$ greater than that for no cover crop (NC), while the Green-Ampt model $K_{S}$ parameter for CC was $31.4 \mathrm{~mm} \mathrm{~h}^{-1}$, about $80 \%$ greater than that for NC. In 2015, the Parlange model $S$ parameter for CC was $38.6 \mathrm{~mm} \mathrm{~h}^{-}$ ${ }^{0.5}$, about $82 \%$ greater than that for NC, while the Green-Ampt $S$ parameter for CC was $34.0 \mathrm{~mm} \mathrm{~h}^{-0.5}$, about $90 \%$ greater than that for NC. The sorptivity $(S)$ parameter value estimated using both models tended to be greater in tilled than no-tilled plots in 2014. The quasi-steady state infiltration rate and field saturated hydraulic conductivity parameters were significantly higher in cover crop compared with no cover crop management.

Cover crops increased infiltration. This can possibly lead to reduced water and nutrient runoff, and increase productivity. Tillage slightly increased infiltration but only for one year, likely because tillage increased pore tortuosity in the next year. Therefore, management practices, like cover crops, that have the potential to increase water infiltration are encouraged.

\section{ACKNOWLEDGEMENTS}

This study was part of a regional collaborative project, 'Cropping Systems Coordinated Agricultural Project: Climate Change Mitigation, and Adaptation in Corn-based Cropping

Systems'. The authors would like to thank the USDA-NIFA for the research support (Award No. 2011-68002-30190). Appreciation is also extended to Phil Markway, 
Sebahattin Acikgoz, Janith Chandrasoma, Dinesh Panday, Ali Al-Sarajji and Vanessa Tate for the help rendered during infiltration measurements. 


\section{REFERENCES}

Abid, M., and R. Lal. 2009. Tillage and drainage impact on soil quality: II. Tensile strength of aggregates, moisture retention and water infiltration. Soil and Tillage Research 103:364-372.

Arriaga, F.J., T.S. Kornecki, K.S. Balkcom, and R.L. Raper. 2010. A method for automating data collection from a double-ring infiltrometer under falling head conditions. Soil use and management 26:61-67.

Auler, A.C., S. Miara, L.F. Pires, A.F.D. Fonseca, and G. Barth. 2014. Soil physicohydrical properties resulting from the management in Integrated Production Systems. Revista Ciência Agronômica 45: 976-989.

Aziz Amoozegar. 2004. Soil permeability and dispersion analysis. In Environmental Instrumentation and Analysis Handbook, eds. Down, R.D., and J.H. Lehr, 644-649. John Wiley and Sons.

Azooz, R.H., M.A. Arshad, and A.J. Franzluebbers. 1996. Pore size distribution and hydraulic conductivity affected by tillage in northwestern Canada. Soil Science Society of America. Journal 60:1197-1201.

Blanco-Canqui, H. M.M. Mikha, D.R. Presley, and M.M. Claassen. 2011. Addition of cover crops enhances no-till potential for improving soil physical properties. Soil Science Society of America Journal 75:1471-1482.

Bouwer, M. 1986. Intake rate cylinder infiltrometer. In: Methods of Soil Analysis, part 1, Physical and mineralogical methods, ed. Klute A, 825-844. Agronomy Monograph 9. Madison, WI: American Society of Agronomy and Soil Science Society of America.

Capowiez, Y., S. Cadoux, P. Bouchant, S. Ruy, J. Roger-Estrade, G. Richard, and H. Boizard. 2009. The effect of tillage type and cropping system on earthworm communities, macroporosity and water infiltration. Soil and Tillage Research 105:209-216.

Clausnitzer, V., J.W. Hopmans, and J.L. Starr. 1998. Parameter uncertainty analysis of common infiltration models. Soil Science Society of America Journal 62:14771487.

Clothier, B., and D. Scotter. 2002. Unsaturated water transmission parameters obtained from infiltration. In: Methods of Soil Analysis, part 4, Physical methods, 879-898. Agronomy monograph 5. Madison, WI: American Society of Agronomy and Soil Science Society of America. 
Connolly R.D., D.M. Freebairn, and B.J. Bridge. 1997. Change in infiltration characteristics associated with cultivation history of soils in south-eastern Queensland. Australian Journal of Soil Research 35:1341-1358.

Dabney, S.M., J.A. Delgado, and D.W. Reeves. 2001. Using winter cover crops to improve soil and water quality. Communications in Soil Science and Plant Analysis. 32:1221-1250.

Daigh, A.L., M.J. Helmers, E. Kladivko, X. Zhou, R. Goeken, J. Cavdini, D. Barker, and J. Sawyer. 2014. Soil water during the drought of 2012 as affected by rye cover crops in fields in Iowa and Indiana. Journal of Soil and Water Conservation 69:564573.

Dapaah, H.K., and T.J. Vyn. 1998. Nitrogen fertilization and cover crop effects on soil structural stability and corn performance. Communications in Soil Science and Plant Analysis 29:2557-2569.

Folorunso, O.A., D.E. Rolston, T. Prichard, and D.T. Loui. 1992. Soil surface strength and infiltration rate as affected by winter cover crops. Soil Technology 5:189-197.

Gardner, J. 1992. Substituting legumes for fallow in U.S great-plains wheat production. Report for first five years of research and demonstration, 1988-1992. USDA/SARE and North Dakota State Univ., Michael Fields Agricultural Institute, Kansas State Univ., and Univ. of Nebraska. NDSU Carrington Research Extension Center, Carrington, N.D.

Green W.H., and G.A. Ampt. 1911. Studies on soil physics Part I. The flow of air and water through soils. Journal of Agricultural Science 4:1-24.

Gulick, S.H., D.W. Grimes, D.A. Goldhamer, and D.S. Munk. 1994. Cover-crop-enhanced water infiltration of a slowly permeable fine sandy loam. Soil Science Society of America Journal 58:1539-1546.

Haramoto, E.R., and E.R. Gallandt. 2004. Brassica cover cropping for weed management: A review. Renewable Agriculture and Food Systems 19:187-198.

Haruna S.I, S.H., Anderson, N.V., Nkongolo and S. Zaibon. 2017. Soil hydraulic properties: influence of tillage and cover crops. In press.

Haruna, S.I., and N.V. Nkongolo. 2015. Effects of tillage, rotation and cover crop on the physical properties of a silt-loam soil. International Agrophysics 29:137-145.

Hopmans, J.W., V. Clausnitzer, K.I. Kosugi, D.R. Nielsen, and F. Somma. 1997. Vadose zone measurement and modeling. Scientia Agricola 54:22-38.

Joyce, B.A., W.W. Wallender, J.P. Mitchell, L.M. Huyck, S.R. Temple, P.N. Brostrom, and T.C. Hsiao. 2002. Infiltration and soil water storage under winter cover 
cropping in California's Sacramento Valley. Transactions of the American Society of Agricultural Engineers 45:315-326.

Jury W.A., and R. Horton. 2004. Soil physics. Wiley, Hoboken.

Kemper, D., and R. Derpsch. 1981. Results of studies made in 1978 and 1979 to control erosion by cover crops and no-tillage techniques in Parańa, Brazil. Soil and Tillage Research 1: 253-267.

Kladivko, E.J., M.J. Helmers, L.J. Abendroth, D. Herzmann, R. Lal, M.J. Castellano, D.S. Mueller, J.E. Sawyer, et al. 2014. Standardized research protocols enable transdisciplinary research of climate variation impacts in corn production systems. Journal of Soil and Water Conservation. 69: 532-542.

Kumar S., S.H. Anderson, R. Udawatta, and R.L. Kallenbach. 2012. Water infiltration influenced by agroforestry and grass buffers for a grazed pasture system. Agroforestry Systems 84:325-335.

Lal, R., and D.M. Vandoren. 1990. Influence of 25 years of continuous corn production by three tillage methods on water infiltration for two soils in Ohio. Soil and Tillage Research 16:71-84.

Lipiec, J., J. Kuś, A. Słowińska-Jurkiewicz, and A. Nosalewicz. 2006. Soil porosity and water infiltration as influenced by tillage methods. Soil and Tillage research, 89:210-220.

Liu J., J. Zhang, and J. Feng. 2008. Green-Ampt model for layered soils with nonuniform initial water content under unsteady infiltration. Soil Science Society of America Journal 72:1041-1047.

Lu S., R.Y. Tusheng, and G.R. Horton. 2008. Evaluation of three models that describe soil water retention curves from saturation to oven dryness. Soil Science Society of America Journal 72:1542-1546.

McVay, K.A., D.E. Radcliffe, and W.L. Hargrove. 1989. Winter legume effects on soil properties and nitrogen fertilizer requirements. Soil Science Society of America Journal 53:1856-1862.

NOAA (National Oceanic and Atmospheric Administration) 2016. NOAA Online Weather Data. Columbia, MO. National Oceanic and Atmospheric Administration. http://w2.weather.gov/climate/index.php?wfo=lsx.

Parlange J.Y., I. Lisle, R.D. Braddock, and R.E. Smith. 1982. The three parameter infiltration equation. Soil Science 133:337-341.

Philip J.R. 1957a. The theory of infiltration: 2. The profile of infinity. Soil Science 83:435448. 
Philip J.R. 1957b. The theory of infiltration: 4 Sorptivity and algebraic infiltration equations. Soil Science 84:257-264.

Pikul, J.L. Jr., and J.F. Zuzel. 1994. Soil crusting and water infiltration affected by longterm tillage and residue management. Soil Science Society of America Journal 58:1524-1530.

Pikul Jr., J.L., D.E. Wilkins, J.K. Aase, and J.F. Zuzel. 1996. Contour ripping: A tillage strategy to improve water infiltration into frozen soil. Journal of Soil and Water Conservation $51: 76-83$.

Pribyl, D.W. 2010. A critical review of the conventional SOC to SOM conversion factor. Geoderma. 156:75-83.

Rachman A., S.H. Anderson, C.J. Gantzer, and A.L. Thmpson. 2004. Influence of stiffstemmed grass hedge systems on infiltration. Soil Science Society of America Journal 68:2000-2006.

Radke, J.K., and E.C. Berry. 1993. Infiltration as a tool for detecting soil changes due to cropping, tillage, and grazing livestock. American Journal of Alternative Agriculture 8:164-174.

Reicosky, D.C., T.J. Sauer, and J.L. Hatfield. 2011. Challenging balance between productivity and environmental quality: Tillage impacts. In Soil Management: Building a Stable Base for Agriculture, eds. Hartfield J.L and T.J. Sauer. American Society of Agronomy and Soil Science Society of America, Madison, WI.

Reynolds W.D., D.E. Elrick, E.G. Youngs, and A. Amoozegar. 2002. Ring or cylinder infiltrometers (vadose zone). In Methods of soil analysis, Part 4, Physical methods, 818-826. Agronomy Monograph 5. Madison, WI: American Society of Agronomy and Soil Science Society of America.

Sainju, U.M., and B.P. Singh. 2008. Nitrogen storage with cover crops and nitrogen fertilization in tilled and non-tilled soils. Agronomy Journal 100:619-627.

SAS (Statistical Analysis Systems) Institute Inc. 2013. SAS user's guide. Statistics. SAS Institute. Cary, NC.

Schulte, K.E., P.J., Culligan, and J.T., Germaine. 2007. Intrinsic sorptivity and water infiltration into dry soil at different degrees of saturation. Geoenvironmental Engineering. 226:1-11.

Shukla, M.K. 2014. Soil physics: An introduction. CRC Press.

Shukla, M.K., R. Lal, L.B. Owens, and P. Unkefer. 2003. Land use and management impacts on structure and infiltration characteristics of soils in the North Appalachian region of Ohio. Soil Science 168:167-177. 
Sims, J.R. 1989. CREST farming: A strategy for dryland farming in the northern greatplains intermountain region. American Journal of Alternative Agriculture 4:85-90.

Talsma, T, and J.Y. Parlange. 1972. One-dimensional vertical infiltration. Australian Journal of Soil Research 10:143-150.

Touma J., M. Voltz, and J. Albergel. 2007. Determining soil saturated hydraulic conductivity and sorptivity from single ring infiltration tests. European Journal of Soil Science 58:229-238.

Troeh F.R., J.A. Hobbs, and R.L. Donahue. 2003. Soil and water conservation for productivity and environmental protection. 4th edition. Prentice Hall.

van Genuchten, M.Th. 1980. A closed-form equation for predicting the hydraulic conductivity of unsaturated soils. Soil Science Society of America Journal 44:892898.

Villamil, M.B., G.A. Bollero, R.G. Darmody, F.W. Simmons, and D.G. Bullock. 2006. No-Till Corn/Soybean Systems Including Winter Cover Crops. Soil Science Society of America Journal 70:1936-1944.

Wilson, G.F., R. Lal, and B.N. Okigbo. 1982. Effects of cover crops on soil structure and on yield of subsequent arable crops grown under strip tillage on an eroded Alfisol. Soil and Tillage Research 2:233-250. 
Table 4.1

Selected soil physical and chemical properties of the Waldron silt loam at various soil depths and horizons.

\begin{tabular}{lllllll}
\hline Depth $(\mathrm{cm})$ & Horizon & Clay $\left(\mathrm{g} \mathrm{kg}^{-1}\right)$ & Silt $\left(\mathrm{g} \mathrm{kg}^{-1}\right)$ & Sand $\left(\mathrm{g} \mathrm{kg}^{-1}\right)$ & $\mathrm{OC}^{\#}\left(\mathrm{~g} \mathrm{~kg}^{-1}\right)$ & $\mathrm{pH}\left(\mathrm{H}_{2} \mathrm{O}\right)$ \\
\hline $0-10$ & Ap & 200 & 650 & 150 & 8.4 & 6.71 \\
$10-20$ & Ap & 210 & 630 & 160 & 8.3 & 6.80 \\
$20-40$ & C1 & 200 & 630 & 170 & 8.3 & 6.79 \\
$40-60$ & Cg1 & 210 & 640 & 150 & 8.3 & 6.85 \\
\hline
\end{tabular}

\# Organic carbon. May be converted to organic matter using a factor of 2.0 (Prybil, 2010) 


\section{Table 4.2}

Means and standard deviation for bulk density (Db) and antecedent volumetric water content (VWC) in the cover crop with tillage (CC-Till), cover crop with no-till (CC-NT), no cover crop with tillage (NC-Till), and no cover crop with no-till (NCNT) treatments in 2014 and 2015.

\begin{tabular}{|c|c|c|c|c|}
\hline \multirow[b]{3}{*}{ Treatment } & \multicolumn{4}{|c|}{ Year } \\
\hline & \multicolumn{2}{|c|}{2014} & \multicolumn{2}{|c|}{2015} \\
\hline & $\mathrm{Db}\left(\mathrm{g} \mathrm{cm}^{-3}\right)$ & VWC $\left(\mathrm{cm}^{3} \mathrm{~cm}^{-3}\right)$ & $\mathrm{Db}\left(\mathrm{g} \mathrm{cm}^{-3}\right)$ & VWC $\left(\mathrm{cm}^{3} \mathrm{~cm}^{-3}\right)$ \\
\hline CC-Till & $1.21 \pm 0.08$ & $0.18 \pm 0.06$ & $1.16 \pm 0.06$ & $0.13 \pm 0.05$ \\
\hline CC-NT & $1.17 \pm 0.14$ & $0.14 \pm 0.05$ & $1.23 \pm 0.07$ & $0.16 \pm 0.06$ \\
\hline NC-Till & $1.14 \pm 0.04$ & $0.15 \pm 0.02$ & $1.19 \pm 0.12$ & $0.19 \pm 0.03$ \\
\hline $\mathrm{NC}-\mathrm{NT}$ & $1.12 \pm 0.08$ & $0.20 \pm 0.11$ & $1.23 \pm 0.11$ & $0.20 \pm 0.03$ \\
\hline \multicolumn{5}{|l|}{ Depth (mm) } \\
\hline $0-100$ & $1.11 \pm 0.08$ & $0.16 \pm 0.05$ & $0.92 \pm 0.06 b$ & $0.12 \pm 0.03$ \\
\hline $100-200$ & $1.20 \pm 0.09$ & $0.18 \pm 0.06$ & $1.26 \pm 0.10 \mathrm{a}$ & $0.19 \pm 0.04$ \\
\hline \multicolumn{5}{|c|}{ Analysis of Variance $p>F$} \\
\hline Treatment & 0.65 & 0.75 & 0.69 & 0.26 \\
\hline NT vs Till & 0.62 & 0.86 & 0.30 & 0.46 \\
\hline $\mathrm{CC}$ vs NC & 0.28 & 0.71 & 0.72 & 0.08 \\
\hline $\mathrm{CC}^{*} \mathrm{Till}^{\#}$ & 0.87 & 0.35 & 0.79 & 0.77 \\
\hline
\end{tabular}

Mean comparisons were only made when $P$ values for the main effects were $\leq 0.05$. Within a soil property, treatment means with different letters for a soil property are significantly different at the 0.05 probability level.

\# Tillage by cover crop interaction 


\section{Table 4.3}

Geometric means for saturated hydraulic conductivity $\left(K_{S}\right)$ and sorptivity $(S)$ parameters estimated by the Parlange and GreenAmpt models in the cover crop with tillage (CC-Till), cover crop with no-till (CC-NT), no cover crop with tillage (NC-Till), and no cover crop with no-till (NC-NT) treatments in 2014 and 2015.

\begin{tabular}{|c|c|c|c|c|}
\hline \multirow[b]{3}{*}{ Treatment } & \multicolumn{4}{|c|}{ Year } \\
\hline & \multicolumn{2}{|l|}{2014} & \multicolumn{2}{|l|}{2015} \\
\hline & $\begin{array}{c}S \\
\left(\mathrm{~mm} \mathrm{~h}^{-0.5}\right)\end{array}$ & $\begin{array}{c}K_{s} \\
\left(\mathrm{~mm} \mathrm{~h}^{-1}\right)\end{array}$ & $\begin{array}{c}S \\
\left(\mathrm{~mm} \mathrm{~h}^{-0.5}\right)\end{array}$ & $\begin{array}{c}K_{s} \\
\left(\mathrm{~mm} \mathrm{~h}^{-1}\right)\end{array}$ \\
\hline \multicolumn{5}{|l|}{ Parlange } \\
\hline CC-Till & 38.7 & $27.9 \mathrm{~b}$ & $36.6 \mathrm{a}$ & 35.7 \\
\hline CC-NT & 33.8 & $49.0 \mathrm{a}$ & $40.6 \mathrm{a}$ & 40.0 \\
\hline NC-Till & 24.3 & $7.31 \mathrm{c}$ & $4.45 b$ & 27.8 \\
\hline NC-NT & 15.7 & $11.8 \mathrm{c}$ & $9.62 b$ & 24.0 \\
\hline \multicolumn{5}{|c|}{ Analysis of Variance $p>F$} \\
\hline Treatment & 0.57 & 0.01 & 0.02 & 0.67 \\
\hline NT vs Till & 0.57 & 0.02 & 0.12 & 0.96 \\
\hline $\mathrm{CC}$ vs NC & 0.24 & 0.01 & 0.03 & 0.27 \\
\hline CC*Till & 0.76 & 0.81 & 0.22 & 0.69 \\
\hline \multicolumn{5}{|l|}{ Green-Ampt } \\
\hline CC-Till & 31.1 & $19.5 b$ & $32.2 \mathrm{a}$ & 27.8 \\
\hline CC-NT & 27.1 & $43.3 \mathrm{a}$ & $35.9 \mathrm{a}$ & 31.8 \\
\hline NC-Till & 24.1 & $4.31 \mathrm{~d}$ & $1.78 b$ & 26.2 \\
\hline NC-NT & 14.7 & $8.49 \mathrm{c}$ & $5.35 b$ & 21.5 \\
\hline \multicolumn{5}{|c|}{ Analysis of Variance $p>F$} \\
\hline Treatment & 0.81 & 0.01 & 0.01 & 0.91 \\
\hline NT vs Till & 0.60 & 0.02 & 0.22 & 0.94 \\
\hline $\mathrm{CC}$ vs NC & 0.48 & $<0.01$ & 0.02 & 0.59 \\
\hline CC $^{*}$ Till $^{\#}$ & 0.77 & 0.68 & 0.30 & 0.69 \\
\hline
\end{tabular}

Mean comparisons were only made when $P$ values for the main effects were $\leq 0.05$. Within a model, treatment means with different letters for a soil property are significantly different at the 0.05 probability level.

\# Tillage by cover crop interaction 


\section{Table 4.4}

Geometric means of quasi-steady state infiltration rate $\left(q_{s}\right)$ and field-saturated hydraulic conductivity $\left(K_{f s}\right)$ in the cover crop with tillage (CC-Till), cover crop with no-till (CC-NT), no cover crop with tillage (NC-Till), and no cover crop with no-till (NC-NT) treatments in 2014 and 2015.

\begin{tabular}{|c|c|c|c|c|}
\hline \multirow[b]{3}{*}{ Treatment } & \multicolumn{4}{|c|}{ Year } \\
\hline & \multicolumn{2}{|l|}{2014} & \multicolumn{2}{|l|}{2015} \\
\hline & $\begin{array}{cc}q_{s}\left(\begin{array}{c}\mathrm{mm} \mathrm{h} \\
1\end{array}\right) \\
\end{array}$ & 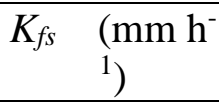 & $q_{s} \quad\left(\mathrm{~mm} \mathrm{~h}^{-1}\right)$ & $\begin{array}{c}K_{f s}(\mathrm{~mm} \\
\left.\mathrm{h}^{-1}\right)\end{array}$ \\
\hline CC-Till & $38.3 \mathrm{a}$ & $30.9 \mathrm{a}$ & 56.5 & 45.6 \\
\hline CC-NT & $30.7 \mathrm{a}$ & $24.8 \mathrm{a}$ & 38.6 & 31.1 \\
\hline NC-Till & $12.5 b$ & $10.1 b$ & 21.9 & 17.7 \\
\hline NC-NT & $13.3 b$ & $10.7 b$ & 27.6 & 22.3 \\
\hline \multicolumn{5}{|c|}{ Analysis of Variance $p>F$} \\
\hline Treatment & 0.01 & 0.01 & 0.26 & 0.26 \\
\hline NT vs Till & 0.49 & 0.49 & 0.36 & 0.36 \\
\hline $\mathrm{CC}$ vs $\mathrm{NC}$ & 0.02 & 0.02 & 0.06 & 0.06 \\
\hline $\mathrm{CC}^{*}$ Till $^{\#}$ & 0.68 & 0.68 & 0.812 & 0.82 \\
\hline
\end{tabular}

Mean comparisons were only made when $P$ values for the main effects were $\leq 0.05$. Within a model, treatment means with different letters for a soil property are significantly different at the 0.05 probability level.

\# Tillage by cover crop interaction 


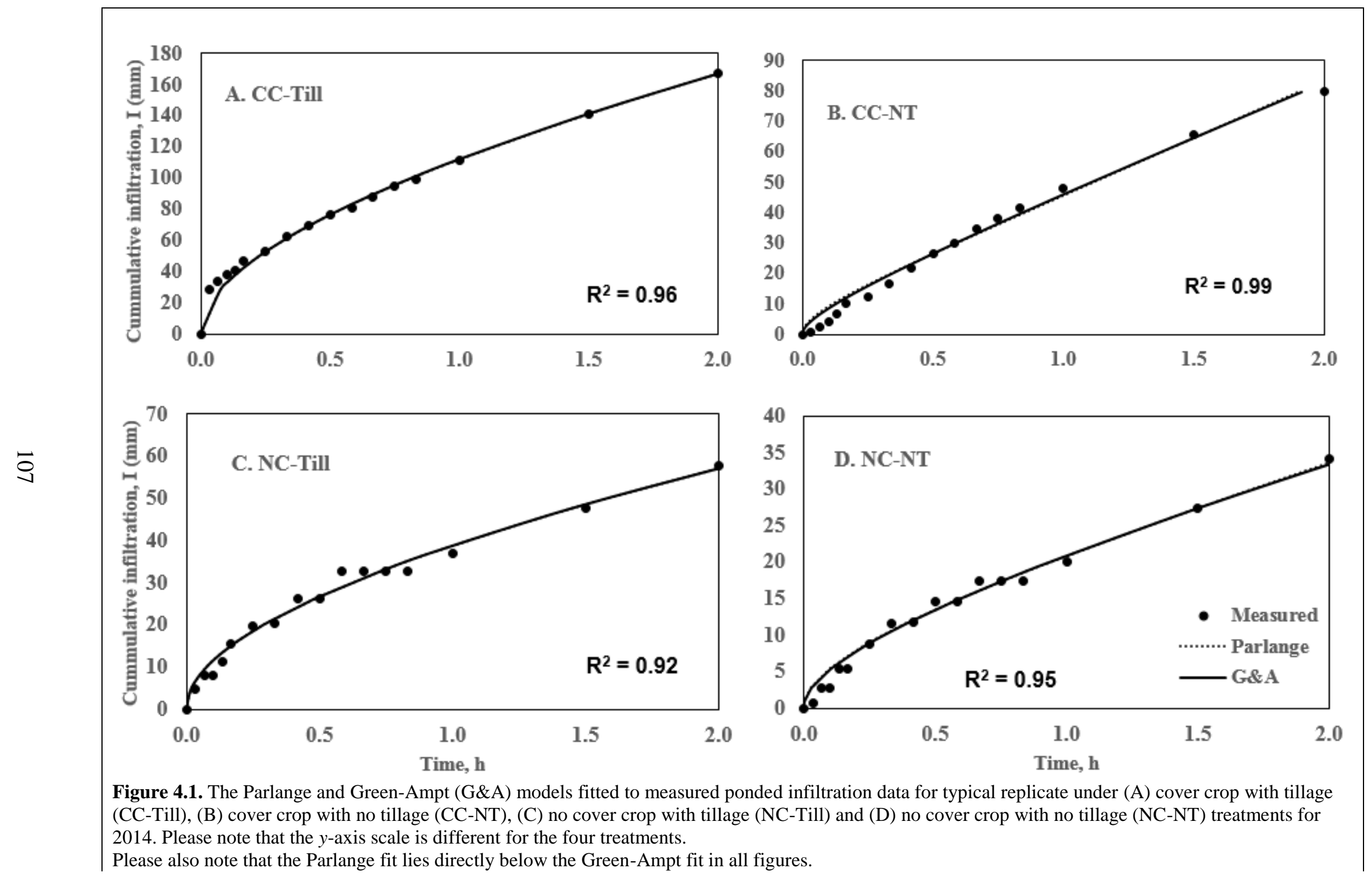




\title{
CHAPTER 5
}

\section{SOIL THRMAL PROPERTIES INFLUENCED BY PERENNIAL BIOFUEL AND COVER CROP MANAGEMENT}

\begin{abstract}
Heat transport is an important factor that can influence the soil environment. A study was conducted at the University of Missouri Bradford Research Center to evaluate the influence of perennial biofuel and cover crops on soil thermal properties. The experimental design included three replicate blocks in a completely randomized design with four treatments. The four treatments included two levels of cover crops (cover crops [CC] vs. no cover crops [NC]) collectively called row crops (RC) and two treatments of biofuel crops. Cover crops used included Cereal rye (Secale cereal L.), Hairy vetch (Vicia villosa L.) and Austrian winter pea (Pisum sativum subsp. arvense). The two biofuel treatments included perennial biofuel crops (PB): giant miscanthus (Miscanthus $x$ gigantus J.M. Geef \& Deuter ex Hodkinson \& Renvoize) and switchgrass (Panicum vergatum L.), both collectively called PB. Soil samples were collected at $10 \mathrm{~cm}$ depth increments from the soil surface to a depth of $30 \mathrm{~cm}$. Soil thermal properties (thermal conductivity $[\lambda]$, volumetric heat capacity $\left[C_{V}\right]$, and thermal diffusivity $\left.[D]\right)$ and volumetric water content $(\theta)$ were determined at $0,-33,-100$ and $-300 \mathrm{kPa}$ soil water pressures. Additionally, bulk density and soil organic carbon (SOC) were determined. Results showed that PB had significantly higher $\theta$ at all pressures measured and also higher SOC compared to RC. As
\end{abstract}


a result, $\mathrm{PB}$ had $11 \%$ higher $C_{V}$ at saturation compared to RC. Cover crops had $18 \%$ higher $\theta$ at saturation and $26 \%$ higher SOC compared to no cover crop; this led to $13 \%$ higher $C_{V}$ in cover crops compared to no cover crop management. Row crops had significantly higher $\lambda$ and $D$ compared to perennial biofuel crops. Results from the current study imply that CC and PB can change soil thermal properties by reducing $\lambda$ and $D$ and increasing $C_{V}$; this indicates that these management systems can improve the ability of the soil to better handle a more variable climate.

Abbreviations: $\mathrm{CC}$, cover crops; $\mathrm{NC}$, no cover crops; PB, perennial biofuel crops; SG, switchgrass; GM, giant miscanthus; RC, row crops; SOC, soil organic carbon. 


\section{INTRODUCTION}

Heat transport through the vadoze zone is an important environmental factor that influences several components and processes of the soil such as water and nutrient transport. Heat transport also plays an important role in microbial activity, seed germination and plant root survival and growth within the soil (Shukla, 2014). It is therefore an important factor that can determine crop productivity. Heat transport within a material can be estimated by measurement of its thermal conductivity $(\lambda)$, volumetric heat capacity $\left(C_{V}\right)$ and thermal diffusivity $(D)$ (Hopmans et al., 2002). These thermal properties can provide information about the ability of the material to transfer heat, buffer against rapid heat change and diffuse heat internally; all of which are essential in estimating heat transport.

Thermal conductivity $(\lambda)$ of a material represents its ability to transport heat and it depends on several factors including mineralogical composition, bulk density, volumetric water content $(\theta)$, soil organic carbon (SOC) (Wierenga et al., 1969; Ren et al., 1999; Ochsner et al., 2001; Heitman et al., 2007; Lu et al., 2007; Heitman et al., 2008; Ju et al., 2011) and soil management (Yardev and Sexana, 1973). Generally, management practices that increase soil compaction tend to increase $\lambda$ since the $\lambda$ of soil minerals is higher than that of air and water (Wierenga et al., 1982; Bristow, 2002). Abu-Hamdeh and Reeder (2002) reported significant differences in $\lambda$ between sand, sandy loam and clay loam soils. These researchers also reported that the smaller particles in the clay loam soils generated more thermal resistance, thus reducing $\lambda$. Also, clays tend to have a higher porosity and this can reduce the contact between soil minerals, thus increasing thermal resistance and reducing $\lambda$. 
Volumetric heat capacity $\left(C_{V}\right)$ measures the ability of a material to resist changes in temperature and it depends on several factors such as $\theta$ and SOC (Yardev and Sexana, 1973; Ochsner et al., 2001; Abu-Hamdeh, 2003; Ju et al., 2011). Since $C_{V}$ of water and SOC are higher than values of air (Bristow, 2002), management practices that increase $\theta$ and SOC have the potential to increase $C_{V}$ (Abu-Hamdeh, 2003).

Thermal diffusivity $(D)$ is a ratio of $\lambda$ and $C_{V}$ (Shukla, 2014) and it can be viewed as a description of the relative ease with which a material transfers heat. Thus, soil management practices that increases $\lambda$ and reduces $C_{V}$ will conduct more heat and buffer less heat change than management practices that have the potential to increase $C_{V}$ and decrease $\lambda$. This may cause higher evaporation of water from the soil, leading to a further decrease in $\theta$ and it may potentially reduce crop productivity.

Thermal conductivity of the soil can be measured by the steady-state method. However, this method involves many significant assumptions such as equal heat flux through the soil and glass and one-dimensional vertical heat flow through the soil (Shukla, 2014). The steady-state method also has a significant limitation of creating a non-uniform profile within the column, primarily due to the redistribution of water under a steady state temperature gradient (Jury and Miller, 1974). To overcome these limitations, the transient method can be used.

The transient method involves the application of heat, either periodically or as a pulse, resulting in periodic (phase signal output) or transient (amplitude signal output) signal changes in the sample, respectively. This method may involve the use of heat probes inserted directly into the soil. This eliminates the need to account for the heat flux through glass. By measuring the phase or amplitude of the pulsed heat wave, the transient method 
accounts for the multi-dimensional heat flow through the soil. The transient method includes minimal soil disturbance, resulting in more uniform distribution of water within the column. All these often leads to better $\lambda$ measurement (Shukla, 2014).

The thermal properties of the soil can be measured quickly and conveniently by the transient method by utilizing heat pulse probes (Campbell et al., 1991; Bristow et al., 1993, 1994a, 1994b; Kluitenberg et al., 1993; Jury and Horton, 2004). The probe consists of two parallel needle-like probes (approximately $1 \mathrm{~mm}$ outer diameter) separated by a distance, r. One probe contains a heater while the other contains a temperature sensor. A heat pulse is applied to the heater probe, and the temperature response is recorded at the sensor probe. If an instantaneous heat pulse is introduced into a material, Campbell et al. (1991) estimated that the maximum temperature rise at a distance, $r$, from the heat source is inversely related to the specific heat capacity and directly related to the amount of heat liberated at the source. This allows for the determination of the thermal properties of the material.

Anthropogenic land management such as tillage, conservation practices and irrigation can alter heat transport within the soil (Adhikari et al., 2014). Abu-Hamdeh and Reeder (2000) reported that tillage could increase soil bulk density, reduce the spaces between soil particles, reduce $\theta$ and alter soil thermal properties. Ochsner et al. (2001) also reported similar findings. Adhikari et al. (2014) reported significant effects of various land management practices on soil thermal properties. These researchers reported that both natural and restored prairies significantly increased SOC and $\theta$ thereby increasing $C_{V}$ compared to a corn and soybean rotation. 
Cover crop adoption into crop rotation systems has seen some increases over the past decade, both in acreage and percentage of farm managers using them, due to their benefits in improving crop productivity, and these benefits have been well documented (Dabney, 2001; Hartwig, 2002; Singer et al., 2007; Blanco-Canqui et al., 2011; Daigh et al., 2014; Haruna and Nkongolo, 2015). Living cover crops can reduce daily maximum soil temperature (Voss and Surmani, 1997; Blanco-Canqui et al., 2011) and provide shade that can reduce evaporation of soil water and maintain $\theta$ (Wagger and Mengel, 1988; Dabney, 2001). By incorporating their biomass into the soil, cover crops can improve SOC (Dabney, 2001). All these factors are hypothesized to alter soil thermal properties.

As a result of the need to find an alternative energy source, several plants including giant miscanthus (Miscanthus $x$ gigantus) and switchgrass (Panicum vergatum) are being grown for conversion to biofuel (Gressel, 2008). Miscanthus is a perennial, warm-season grass native to Asia with the $\mathrm{C} 4$ photosynthetic pathway. Miscanthus species have been used for forage and roofing in Japan for many decades, and they were managed through grazing and burning (Stewart et al., 2009). They have been studied in several European countries and are now being used commercially for heat and power generation (Jones \& Walsh, 2001). In the USA, research into miscanthus began in 2001 (Pyter et al., 2007) and it has been proposed for use as a supplement for heat and power generation (Heaton et al., 2004, Khanna et al., 2008).

Switchgrass is also a perennial warm-season grass with a $\mathrm{C} 4$ photosynthetic pathway and it is native to most of North America (Vogel, 2004). Switchgrass has several characteristics that make it a desirable biomass energy crop: it has consistently high yield relative to other species in varied environments, it requires minimal agricultural inputs, and 
it is relatively easy to establish from seed (McLaughlin and Kzsos, 2005; Parrish and Fike, 2005; Sanderson et al., 2007).

Currently, several studies have quantified the influence of cover crops, miscanthus and switchgrass on soil physical properties such as bulk density, $\theta$, and pore size distributions. However, studies on the influence of cover crops, miscanthus and switchgrass on soil thermal properties are currently lacking. Therefore, the objective of this study was to evaluate the influence of perennial biofuel and cover crops on $\theta, \mathrm{SOC}$, bulk density and soil thermal properties.

\section{MATERIALS AND METHODS}

\section{Site Description}

The study was conducted at the University of Missouri Bradford Research Center, located about $18 \mathrm{~km}$ east of Columbia. The soil was classified by the United States Department of Agriculture (USDA) as Mexico silt loam (fine, smectitic, mesic Vertic Epiaqualf). Table 5.1 shows soil texture for the three sampling depths of the study. The average annual precipitation for the area is about $1083 \mathrm{~mm}$, with the months of January (49 $\mathrm{mm})$ and May $(126 \mathrm{~mm})$ being the driest and wettest months, respectively. The average annual temperature is about $12.5^{\circ} \mathrm{C}$ with the months of July $\left(31^{\circ} \mathrm{C}\right)$ and January $\left(-6^{\circ} \mathrm{C}\right)$ being the warmest and coldest months, respectively.

The experimental design included three replicate blocks in a completely randomized design, with two levels of cover crops (cover crops [CC] vs. no cover crop $[\mathrm{NC}])$, also collectively referred to as row crops (RC) and two perennial biofuel crops. A suite of three cover crops was used for the cover crop treatment; Cereal rye (Secale cereal 
L.), Hairy vetch (Vicia villosa L.) and Austrian winter pea (Pisum sativum subsp. arvense). The main grain crop grown was continuous corn (Zea mays L.), planted in May and harvested in September of each growing season. The soil was under no tillage management. The perennial biofuel crops (PB) included giant miscanthus (GM) (Miscanthus $x$ gigantus J.M. Geef \& Deuter ex Hodkinson \& Renvoize) and Switchgrass (SG) (Panicum vergatum L.), both referred to as perennial biofuel crops henceforth.

The cover crop plots were established in 2010. The cover crops were seeded every year in September and October, allowed to grow throughout the winter months, and then terminated in late spring of the next year. For this study, the cover crops were over-seeded on September 8, 2014 and then drilled in on October 1, 2014 at the following rates; Cereal rye $\left(50 \mathrm{~kg} \mathrm{ha}^{-1}\right)$, Hairy vetch $\left(17 \mathrm{~kg} \mathrm{ha}^{-1}\right)$ and Austrian winter pea $\left(34 \mathrm{~kg} \mathrm{ha}^{-1}\right)$ using a Kinze $^{\circledR} 38 \mathrm{~cm}$ row planter with special blades that allowed small seeded cover crops to be planted. The cover crops were allowed to grow during the winter months and terminated in June using glyphosate (n-[phosphonomethyl] glycine). The perennial biofuel crops were established in 2007. Miscanthus seedlings were hand planted (plugs) in a 0.9 x $0.9 \mathrm{~m}$ grid (1984 plants ha ${ }^{-1}$ ). Switchgrass was planted using a Tye Drill in $19 \mathrm{~cm}$ spacing at $7 \mathrm{~kg} \mathrm{ha}^{-}$

1. The PB were harvested with a silage chopper each year and the biomass was removed and used for simulated biofuel production. All plots were rain-fed throughout the study.

\section{Soil Sampling and Analysis}

Soil samples were collected to determine bulk density, soil organic carbon (SOC), volumetric water content and thermal properties using a sampler with a cylindrical core measuring $76.2 \mathrm{~mm}$ diameter by $76.2 \mathrm{~mm}$ long. The samples were collected from nontrafficked row areas just before cover crop termination in early June 2015 at three soil 
depths; 0-10, 10-20 and 20-30 cm. A total of 36 samples were collected (4 treatments x 3 replicates x 3 depths). After the samples were collected, they were trimmed, labelled and secured with plastic caps at both ends using masking tape. They were stored in a cold storage room at $4^{\circ} \mathrm{C}$ until analysis was done.

After removing the soil cores from the cold storage, the plastic caps were gently removed. Cheesecloth was placed at the bottom of each core and secured using rubber bands. They were placed in a tub and saturated with tap water for about 48 hours by gently raising the water level. The electrical conductivity of the water was $0.68 \mathrm{dS} \mathrm{m}^{-1}$. After saturation, the samples were weighed, placed on pressure plates and equilibrated to -33 , 100 and $-300 \mathrm{kPa}$ (Dane and Hopmans, 2002) pressures in a temperature-controlled room $\left(25^{\circ} \mathrm{C}\right)$. The soils were weighed after equilibration at each pressure and water content was determined at each of those pressures.

Thermal properties were determined using a KD2 (Decagon Devices) dual-probe heat-pulse sensor. This sensor is similar to the one used by several researchers (e.g Campbell et al., 1991; Bristow et al., 1993; Kluitenberg et al., 1993; Dahiya et al., 2007). The probe was calibrated before measurement and its accuracy was tested using performance verification standards. The probe was inserted vertically into the soil and thermal properties were recorded at each pressure $(0,-33,-100$ and $-300 \mathrm{kPa})$. Care was taken to ensure proper contact between the soil and the probes as improper contact can lead to errors in measurement (Abu-Hamdeh, 2001). This was done by inserting the probe into new areas during each measurement and also avoiding core walls. Due to the presence of shrink-swell clays, thermal properties were not measured beyond $-300 \mathrm{kPa}$ since there might be a risk of crack development at lower pressures. 
After thermal properties and volumetric water content $(\theta)$ were measured, the soil was oven dried at $105^{\circ} \mathrm{C}$ and bulk density was measured using the core method (Grossman and Reinsch, 2002). The soil was then ground, passed through a $2 \mathrm{~mm}$ sieve. $50 \mathrm{~g}$ of the < $2 \mathrm{~mm}$ particles were used for soil texture determination using the pipette method (Gee and Or, 2002). Another $10 \mathrm{~g}$ of the $<2 \mathrm{~mm}$ aggregates were used for SOC determination. Soil organic carbon was determined by combustion analysis in a Leco C-144 carbon analyzer at the University of Missouri Soil Health Laboratory.

\section{Statistical Analysis}

A test of normality was conducted within each treatment, depth and water pressure for bulk density, SOC, water content and thermal properties using Anderson-Darling at $P$ $=0.05$ using SAS ver 9.4 (SAS Institute). Normality tests showed that all data were normally distributed. Analysis of variance (ANOVA) was further conducted using the general linear method (GLM). Single degree of freedom contrasts for the four treatments (row crop and perennial biofuel crops) effects were divided into 'row crop vs perennial biofuel crops', 'no cover crop vs cover crop', and 'switchgrass vs miscanthus'. Analysis of variance was also conducted to determine the treatment*depth interaction on bulk density, SOC, water content and all thermal properties measured. Statistical differences were declared to exist at $\mathrm{p} \leq 0.05$.

\section{RESULTS AND DISCUSSION}

\section{Soil Organic Carbon and Bulk Density}

The soil organic carbon (SOC) and bulk density means (with standard errors) averaged over the three depths and analysis of variance are shown in Table 5.2. Results 
show significant treatment effects on both SOC $(\mathrm{p}<0.001)$ and bulk density $(\mathrm{p}<0.01)$. The contrast between row crop and perennial biofuel crops (RC vs. PB) was significant for both SOC and bulk density. Soil organic carbon and bulk density were also significantly different between cover crops and no cover crop (CC vs. NC) management. Besides these contrasts, sampling depth and treatment by depth interaction (treatment*depth) were also significant for both SOC and bulk density ( $<$ 0.001) (Table 5.2).

Soil organic carbon under PB management was $21 \mathrm{~g} \mathrm{~kg}^{-1}$, about $29 \%$ higher than that under RC management. Perennial biofuel crops have higher above ground biomass that can grow for several years. They (PB) also have more extensive roots compared to RC management. The decomposition of this biomass may have resulted in higher SOC in PB compared to RC. Furthermore, anthropogenic factors such as annual row crop production may lead to a faster SOC depletion compared to the perennial crops. Soil organic carbon under $\mathrm{CC}$ management was $17 \mathrm{~g} \mathrm{~kg}^{-1}$, about $26 \%$ higher than that under $\mathrm{NC}$ management (Table 5.2). This is presumed to be a result of the decomposition of below ground cover crop biomass (roots). Kuo et al (1997), Sainju et al. (2002) and Villamil et al., (2006) reported $7 \%, 12 \%$ and $9 \%$ increases in SOC respectively with the use of various cover crops (CC) compared with no cover crops (NC). The difference in SOC between CC and NC was higher in the current study compared to previous studies. This may be because a suite of different cover crops was used in the current study as opposed to a single cover crop. The various cover crops will increase belowground biomass significantly, which may lead to increased SOC.

Improvements in SOC have been related to increased carbon sequestration (Allmaras et al., 2000; Post and Kwon, 2000; West and Post, 2002; Lal, 2004; 
Franzluebbers, 2005). Lal (2004) reported that besides enhancing food security, carbon sequestration has the potential to offset global fossil fuel emissions by 5 to $15 \%$ ( 0.4 to 1.2 gigatons of carbon) per year. Results from the current study suggest that PB may significantly improve carbon sequestration compared to RC management while CC may lead to improved carbon sequestration compared to $\mathrm{NC}$ management and these management systems (PB and CC) may help counteract fossil fuel emissions.

As expected, SOC decreased with increasing depth probably due to reduced biomass with increasing depth. Treatment by depth interactions showed that SOC was significantly different among all treatments in the 0-10 cm depth, with SOC in GM > SG $>\mathrm{CC}>\mathrm{NC}$. However, in the 10-20 and 20-30 cm depths, SOC was not significantly different among the $\mathrm{PB}$ treatments but was different between $\mathrm{PB}$ and $\mathrm{RC}$ and also between $\mathrm{CC}$ and $\mathrm{NC}(\mathrm{GM}=\mathrm{SG}>\mathrm{CC}>\mathrm{NC})($ Table 5.2).

Results show that bulk density under RC management was $1.38 \mathrm{~g} \mathrm{~cm}^{-3}$, about $7 \%$ higher than that under PB management. This corresponds to SOC results. Results also show that bulk density was significantly higher in NC compared to CC management (Table 5.2). Bulk density increased with depth from $0-10 \mathrm{~cm}$ to $10-20 \mathrm{~cm}$ but was similar between $10-20 \mathrm{~cm}$ and $20-30 \mathrm{~cm}$ depths. Treatment by depth interactions showed that bulk density was significantly different $(\mathrm{p}<0.05)$ between $\mathrm{RC}$ and PB management at the first depth, but was not different among the RC and the PB treatments for this depth $(\mathrm{NC}=\mathrm{CC}>\mathrm{SG}$ $=\mathrm{GM})$. The presence of plant roots at this depth was presumed to be responsible for lowering bulk density in both PB and CC management compared with NC. There were no significant differences in bulk density among all management systems at the $20-30 \mathrm{~cm}$ depth. 
Generally, SOC decreased with increasing bulk density among various management systems and between the first two soil depths. The addition of plant biomass and plant roots has been reported to increase SOC, reduce bulk density and improve soil structure (Mishra et al., 2003). The significant differences in SOC and bulk density between PB and RC management systems are presumed to be because of higher below ground biomass and root density in PB management noticed during sample collection. Similarly, Tufekcioglu et al. (1998) reported about 33\% higher root density in PB (switchgrass) compared to RC management. These roots can relieve soil compaction and thus soil bulk density.

\section{Volumetric Water Content}

The volumetric water content $(\theta)$ means (with standard errors) averaged over the three depths and analysis of variance for all treatments at $0,-33,-100$ and $-300 \mathrm{kPa}$ pressures are shown in Table 5.2. The treatment effect was significant at all soil water pressures measured $(\mathrm{p}<0.05)$. The $\mathrm{RC}$ vs. PB contrast was significant at all pressures measured. Results showed that $\theta$ under PB management at $0,-33,-100$, and $-300 \mathrm{kPa}$ pressures were $0.54,0.37,0.35$, and $0.33 \mathrm{~cm}^{3} \mathrm{~cm}^{-3}$, respectively. Under RC management, $\theta$ at $0,-33,-100$, and $-300 \mathrm{kPa}$ pressures were $23,10,10$ and $9 \%$ lower, respectively, than that under PB management at these pressures. The $\mathrm{NC}$ vs. CC contrast was significant at 0 and $-33 \mathrm{kPa}$ pressures. At saturation, $\theta$ under $\mathrm{CC}$ management was $0.45 \mathrm{~cm}^{3} \mathrm{~cm}^{-3}$, about $18 \%$ higher than that under NC management. At $-33 \mathrm{kPa}$ pressure, $\theta$ under $\mathrm{CC}$ was 0.35 $\mathrm{cm}^{3} \mathrm{~cm}^{-3}$, about $11 \%$ higher than that under NC management.

Soil organic carbon can improve soil structure, and associated with improved soil structure is higher porosity. Also, growing plant roots can create new pores while dead and 
decaying roots can leave empty pores (Murphy et al., 1993; Fuentes et al., 2004), thus increasing porosity. Besides higher SOC, PB also have higher root densities compared to RC (Tufekcioglu et al., 1998) and these roots (switchgrass) can grow up to $300 \mathrm{~cm}$ depth (Ma et al., 2000; Mann et al., 2012). These roots can increase pore size distribution and the volume of transmission pores. Zaibon et al., (2016) reported that switchgrass had 53 and $27 \%$ higher macropores (> $1000 \mu \mathrm{m}$ diameter) and coarse mesopores $(60-1000 \mu \mathrm{m}$ diameter) compared to RC management respectively. Furthermore, Mitchell et al. (1995) reported that PB could create more stable macropores compared to RC. All these factors are presumed to be responsible for the higher $\theta$ found in $\mathrm{PB}$ compared to $\mathrm{RC}$ management and the lower $\theta$ found in $\mathrm{NC}$ management between 0 and $-33 \mathrm{kPa}$ pressures.

In a study by Haruna et al. (2017), it was reported that cereal rye CC had $30 \%$ more macropores compared to NC management, averaged over two depths $(0-10$ and 10-20 cm) two weeks after CC termination and spring tillage. Villamil et al. (2006) reported significant increases in the volume of interconnected pores in cover crop compared to no cover crop management. Water drainage occurs rapidly through these interconnected macropores and may account for the higher $\theta$ in $\mathrm{CC}$ compared to $\mathrm{NC}$ managements between 0 and $-33 \mathrm{kPa}$ pressure noticed in the current study. The higher $\theta$ in $\mathrm{CC}$ compared to $\mathrm{NC}$ at $-33 \mathrm{kPa}$ suggests that $\mathrm{CC}$ may have higher mesopores (10-1000 $\mu \mathrm{m}$ diameter) compared to NC.

Soil sampling depth also had significant effects at all pressures measured ( $\mathrm{p}<$ 0.001) (Table 5.2). Volumetric water content reduced with depth from 0-10 to $10-20 \mathrm{~cm}$ but was not significantly different between $10-20$ and 20-30 cm depths. This was in concert with bulk density results (Table 5.2). The treatment by depth interaction was also 
significant at all pressures measured $(\mathrm{p}<0.005)$. Results show that at saturation, $\theta$ was significantly higher in $\mathrm{PB}$ compared to $\mathrm{RC}$ and also in $\mathrm{CC}$ compared to $\mathrm{NC}$ but not significantly different among the $\mathrm{PB}$ at all depths ( $\mathrm{SG}=\mathrm{GM}>\mathrm{CC}>\mathrm{NC}$ ). However, $\theta$ was numerically higher in SG compared to GM at $0-10$ and $20-30 \mathrm{~cm}$, while $\theta$ was numerically higher in GM compared to SG at $10-20 \mathrm{~cm}$ depths.

\section{Thermal Conductivity}

The thermal conductivity $(\lambda)$ means (with standard errors) averaged over the three depths and analysis of variance for all treatments at $0,-33,-100$ and $-300 \mathrm{kPa}$ pressures are shown in Table 5.3. Figure 5.1 a-h shows the $\lambda$ data plotted as a function of water pressure for each of the depths measured, an additional graph shows the data presented as a function of depth. Averaged over three depths, results show a significant treatment effect on $\lambda$ values at saturation. The RC vs. $\mathrm{PB}$ contrast was significant at $0,-33$ and $-100 \mathrm{kPa}$ pressures and it showed that RC had 10, 5 and 5\% higher $\lambda$ values compared to PB respectively. The SG vs. GM contrast was significant at $0 \mathrm{kPa}$ and it showed that $\mathrm{SG}$ had $9 \%$ higher $\lambda$ values compared to GM management.

The $\lambda$ values observed from the current study at saturation ranged between 1.10 and $1.42 \mathrm{~W} \mathrm{~m}^{-1} \mathrm{~K}^{-1}$. Abu-Hamdeh (2000) reported $\lambda$ values ranging from 0.40 to $0.79 \mathrm{~W} \mathrm{~m}^{-1}$ $\mathrm{K}^{-1}$ for a no-till loam soil at water contents between 0.10 to $0.18 \mathrm{~cm}^{3} \mathrm{~cm}^{-3}$. The higher $\lambda$ values from the current study are probably due to the higher water content ( 0.29 to 0.54 $\mathrm{cm}^{3} \mathrm{~cm}^{-3}$ ). At each soil depth, the highest and lowest $\lambda$ values were observed in $\mathrm{NC}$ and GM management respectively (Fig. 5.1a-c). The NC management had the highest bulk density and lowest SOC values while GM management had the highest SOC and lowest bulk density values. The higher $\lambda$ values in NC are probably due to the fact that $\lambda$ increases 
with an increase in bulk density and a decrease in SOC (Abu-Hamdeh and Reeder, 2003). As bulk density increases, the contact between soil particles also increases, thus increasing $\lambda$. Furthermore, the $\lambda$ of SOC $\left(0.25 \mathrm{~W} \mathrm{~m}^{-1} \mathrm{~K}^{-1}\right)$ is lower than that of clay minerals $(2.9 \mathrm{~W}$ $\mathrm{m}^{-1} \mathrm{~K}^{-1}$ ) (Bristow, 2002), and SOC can also reduce bulk density; thus higher SOC can reduce $\lambda$.

In general, $\lambda$ values decreased rapidly with decreasing soil water pressure from saturation to $-33 \mathrm{kPa}$ for all treatments and all depths measured (Fig. 5.1a-c). This was presumed to be because of the significant water drainage between these pressures (Table 5.2). Significant water drainage from soil pores causes air to replace the drained water. The $\lambda$ value of air $\left(0.025 \mathrm{~W} \mathrm{~m}^{-1} \mathrm{~K}^{-1}\right)$ is significantly lower than that of water $\left(0.57 \mathrm{~W} \mathrm{~m}^{-1} \mathrm{~K}^{-1}\right)$ (Bristow, 2002), thus reducing $\lambda$ values from saturation to $-33 \mathrm{kPa}$ pressures. Several researchers working on different soils and management practices (e.g. Ghuman and Lal, 1985; Ochsner et al., 2001; Abu-Hamdeh et al., 2001; Mori et al., 2003) all reported that $\lambda$ values decreased with decreasing $\theta$. However, the decrease in $\lambda$ values between saturation and $-33 \mathrm{kPa}$ pressures was higher in the current study compared to the previous studies. This is probably due to the increased water drainage at these pressures ( 0 and $-33 \mathrm{kPa})$, especially under the $\mathrm{PB}$ and $\mathrm{CC}$ managements. Between -33 and $-300 \mathrm{kPa}, \lambda$ values decreased slightly for all treatments and all depths measured (Fig. 5.1).

At all pressures measured, $\lambda$ values were numerically highest at the $10-20 \mathrm{~cm}$ soil depth compared to other depths (Table 5.3). This was expected since the distance between soil particles was lower at this depth due to slightly higher bulk density.

At saturation, $\lambda$ values were significantly lower in GM compared with other treatments at all depths (Fig. 5.1d). This was presumed to be as a result of higher SOC and 
lower bulk density under this management. At $-33 \mathrm{kPa}$ pressure, there were no significant differences in $\lambda$ values between CC and NC. However, RC had higher $\lambda$ values in the $0-10$ cm depth compared to PB (Fig. 5.1e). Between -100 and -300 kPa pressures, NC had significantly higher $\lambda$ values compared to other management at the top $10 \mathrm{~cm}$ depth only (Fig. 5.1f-g). This result shows that as the soil dries out, $\lambda$ values were only different in the $0-10 \mathrm{~cm}$ depth. Therefore, as $\theta$ reduces the role of SOC and bulk density become even more evident, especially at the soil surface. The higher SOC and lower bulk density in PB and CC compared to NC at this depth (Table 5.2) may reduce $\lambda$. This demonstrates the influence of the management practices in maintaining optimum soil temperatures for plant growth, especially in the warmer summer months.

\section{Volumetric Heat Capacity}

The volumetric heat capacity $\left(C_{V}\right)$ means (with standard errors) averaged over the three depths and analysis of variance for the treatments at $0,-33,-100$ and $-300 \mathrm{kPa}$ pressures are shown in Table 5.3. Figure 5.2 shows $C_{V}$ data plotted as a function of water pressure for each of the depths measured, an additional graph shows the data presented as a function of depth. The $C_{V}$ data estimated using the de Vries (1965) model was very similar to the measured values with a root mean square error (RMSE) of 0.013. Averaged over the three depths, there was a significant treatment effect $(\mathrm{p}<0.001)$ on $C_{V}$ at all pressures measured. Significant contrasts included RC vs. PB and NC vs. CC (p < 0.001). At $0,-33$, -100 and $-300 \mathrm{kPa}$ pressures, $\mathrm{PB}$ had $11,9,9$, and $9 \%$ higher $C_{V}$ values respectively compared to RC. At 0, -33, -100 and $-300 \mathrm{kPa}$ pressures, $\mathrm{CC}$ had 13,16, 16 and $16 \%$ higher $C_{V}$ values compared to $\mathrm{NC}$ respectively. 
Generally, $C_{V}$ values were observed to decrease significantly from saturation to $33 \mathrm{kPa}$ pressures at all depths measured (Fig. 5.2a-c). Between -33 and -300 kPa pressures, $C_{V}$ values reduced slightly for some management practices (e.g. CC, GM and SG) and leveled off for other management practice (e.g. NC) at all depths. This was consistent with the results of Abu-Hamdeh (2003) who reported that there was a linear relationship between $C_{V}$ and $\theta$ for both sandy and clayey soils. The reason for the sharp decrease in $C_{V}$ values between saturation and $-33 \mathrm{kPa}$ pressure was presumed to be due to higher water drainage between these pressures. The $C_{V}$ values of water $\left(4.18 \mathrm{MJ} \mathrm{m}^{-3} \mathrm{~K}^{-1}\right)$ and organic carbon $\left(2.50 \mathrm{MJ} \mathrm{m}^{-3} \mathrm{~K}^{-1}\right)$ are both relatively higher than the $C_{V}$ values of clay minerals (1.20 $\mathrm{MJ} \mathrm{m}^{-3} \mathrm{~K}^{-1}$ ) (Bristow, 2002). Higher water content encouraged by improved soil structure and porosity caused by SOC and plant roots were presumed to be the reason for the relatively higher $C_{V}$ values in $\mathrm{PB}$ and $\mathrm{CC}$ compared to $\mathrm{NC}$ at all pressures and depths measured (Fig. 5.2). The higher SOC values under these management systems were also believed to have helped increase the $C_{V}$ values. Besides acting as a buffer, SOC with its higher surface area, can also increase the amount of water films held between soil particles, thus increasing $C_{V}$ values in soils with higher SOC.

Depending on the depth sampled and the time of the season, plant canopy may serve as a shade, thus reducing soil water evaporation. Daigh et al., (2014) reported that in a drought year, $\mathrm{CC}$ improved water conservation by reducing water evaporation from the soil compared to NC. Blanco-Canqui et al., (2011) reported similar findings. This effect may be more pronounced on the soil surface (Table 5.2). Living vegetation, like PB and CC, can increase soil coverage (Haramoto and Gallandt, 2005) and this can reduce soil water loss due to evaporation (Blanco-Canqui et al., 2011). Increased water content due to 
reduced soil water evaporation may also help increase $C_{V}$ values in $\mathrm{PB}$ and $\mathrm{CC}$ compared to NC management.

Averaged across all management practices, $C_{V}$ values decreased numerically with an increase in soil depth (Table 5.3). This was consistent with SOC results. At the $0-10 \mathrm{~cm}$ depth at saturation, the increasing order of $C_{V}$ values were $\mathrm{NC}\left(3.11 \mathrm{MJ} \mathrm{m}^{-3} \mathrm{~K}^{-1}\right), \mathrm{CC}(3.66$ $\mathrm{MJ} \mathrm{m}^{-3} \mathrm{~K}^{-1}$ ), SG (3.74 $\left.\mathrm{MJ} \mathrm{m}^{-3} \mathrm{~K}^{-1}\right)$ and $\mathrm{GM}\left(3.84 \mathrm{MJ} \mathrm{m}^{-3} \mathrm{~K}^{-1}\right.$ ) (Fig. 5.2d). At 10-20 and 20$30 \mathrm{~cm}$ depths, PB had 12 and $11 \%$ higher $C_{V}$ values compared to RC, while CC had 14 and $5 \%$ higher $C_{V}$ values compared to $\mathrm{NC}$ respectively. Between -33 and $-300 \mathrm{kPa}$ pressures, NC had the lowest $C_{V}$ values at all depths.

Due to their higher $C_{V}$ values noticed in the current study, CC and PB can help provide optimum soil temperature for plant growth and microbial activity by resisting rapid heat change and transport. This is important since most plants are more sensitive to soil temperature than aboveground air temperature (Brady and Weil, 2008). Maintaining optimal soil temperature is also important because most plants have a narrow range of soil temperatures for optimal root growth (Kasper and Bland, 1992) and plant development. For example, in temperate regions, cold soil temperature can limit the productivity of grain crops like corn (Zea mays L.) and soybean (Glycine max.). The rates of microbial activity, such as respiration, also doubles for every $10^{\circ} \mathrm{C}$ rise in temperature (MacDonalds et al., 1995). Thus, maintaining optimal soil temperature is important for microbial nutrient cycling.

Furthermore, optimal soil temperature is also dependent on net radiation and surface albedo. As a result of their higher $C_{V}$ values and dull appearance, wetter soils have lower albedo values compared to drier soils (Shukla, 2014). In a world with increasing 
concerns over climate variability, cover crops (CC) and perennial biofuel crops (PB) may help improve the $C_{V}$ of soils by increasing SOC and soil water content and this may lead to more sustainable crop production system. Besides $\mathrm{CO}_{2}$ sequestration (Lal, 2002), these crops $(\mathrm{CC}$ and $\mathrm{PB})$ can also reduce $\mathrm{CO}_{2}$ emissions from soils by delaying organic matter decomposition due to their higher $C_{V}$.

\section{Thermal Diffusivity}

The thermal diffusivity $(D)$ means (with standard errors) averaged over the three depths and analysis of variance for the treatments at $0,-33,-100$ and $-300 \mathrm{kPa}$ pressures are shown in Table 5.3. Figure 5.3 shows $D$ data plotted as a function of water pressure for each of the depths measured, an additional graph shows the data presented as a function of depth. Averaged over the three depths at saturation, $D$ was significantly different among the various treatments $(\mathrm{p}<0.001)$. The $\mathrm{RC}$ vs $\mathrm{PB}$ contrast was significant and it showed that RC had $21 \%$ higher $D$ values compared to PB management. The NC vs CC contrast was also significant at saturation and it showed that $D$ values were $14 \%$ higher in NC compared to $\mathrm{CC}$ treatment. Thermal diffusivity was significantly different among $\mathrm{PB}$ treatments at saturation and it showed that $D$ values were $9 \%$ higher in switchgrass (SG) compared to miscanthus (GM) (Table 5.3). At -33, -100 and -300 kPa pressure, $D$ was 14 , 15 and 14\% higher in RC compared to PB management respectively. At $-33,-100$ and $300 \mathrm{kPa}$ pressure, $D$ was 17,18 and $16 \%$ higher in $\mathrm{NC}$ compared to $\mathrm{CC}$ management respectively.

No cover crop management had the highest $D$ values compared to other management at all pressures measured and this suggests that NC conducts more heat and buffers less heat change compared to the other management practices. Due to less soil 
vegetative cover in $\mathrm{NC}$, soil water evaporation may be higher in NC compared to the other treatments. However, this would depend on soil conditions like texture and structure and on atmospheric conditions like temperature and relative humidity. Higher temperature and lower humidity often leads to increased soil water evaporation. On bare soils, such as NC, soil water evaporation may occur in two stages. The first stage involves evaporation at the soil surface and it is limited by the atmospheric evaporative demand. The second stage begins to occur after the surface moisture is depleted and evaporation shifts from the soil surface to the subsurface. The second stage is controlled by soil properties and may lead to the formation of dry soil surface layer (Yamanaka et al., 1998). Thus, excessive evaporation of water and the formation of dry surface layer may reduce soil water and nutrient availability, microbial activity and it may potentially reduce crop yields.

Thermal diffusivity can also increase crop productivity by increasing the length of the growing season of crops. Lower $C_{V}$ (thus increased $\lambda$ ) can lead to rapid soil temperature increase in spring. This can help warm up the soil and lead to earlier planting and seed emergence. This is of great importance for frozen soils.

Generally, $D$ values increased with a decrease in water pressure from saturation to $-33 \mathrm{kPa}$ for all treatments at all depths (Fig. 5.3a-c). Also, the rate of decrease in $C_{V}$ was faster than the rate of decrease in $\lambda$ at these pressures. Therefore, the non-linear effect of $\theta$ on these properties $\left(\lambda\right.$ and $\left.C_{V}\right)$ may have resulted in the higher $D$ between saturation and $33 \mathrm{kPa}$ pressures. In contrast, Porter at al. (1985), Usowich et al. (2009) and Adhikari et al. (2014) all reported that increased water drainage between these pressures increased $\lambda$ by increasing the contact area between soil particles, thus increasing $D$. However, AbuHamdeh (2003) only found this relationship to be true for sandy soils and not clay soils. 
Thermal diffusivity values, in the current study, reduced from -33 to $-100 \mathrm{kPa}$ and leveled off between -100 and $-300 \mathrm{kPa}$.

At each sampled depth and all soil water pressures measured, $D$ values were highest in NC management (Fig. 5.3). Compared to NC, CC management had lower $D$ values probably due to higher SOC and lower bulk density in CC compared to NC management. Furthermore, $\mathrm{CC}$ had a more pronounced influence on $C_{V}$ compared to $\lambda$ and this was probably why CC had a significant influence on $D$. At all depths sampled, $D$ values were highest in NC management compared with other management, with the greatest difference occurring at the 0-10 cm depth (Fig. 5.3d-g).

\section{SUMMARY AND CONCLUSIONS}

This study was conducted to evaluate the influence of cover crops and perennial biofuel crops on heat transport parameters under laboratory controlled conditions. Results show that soil organic carbon was about $29 \%$ higher under perennial biofuel compared to row crop management due to higher vegetation density and this lead to $7 \%$ higher bulk density under row crop compared to perennial biofuel management. Soil organic carbon was also about $26 \%$ higher in cover crop compared to no cover crop management.

Thermal conductivity and volumetric heat capacity decreased while thermal diffusivity increased with a decrease in pressure from saturation to $-33 \mathrm{kPa}$ in all treatments probably due to the equilibrium relationship between water and air. At saturation, row crops had $10 \%$ higher thermal conductivity compared to perennial biofuel crops, while cover crops had $13 \%$ higher volumetric heat capacity compared to no cover crops. At all pressures measured, perennial biofuel crops had significantly higher volumetric heat 
capacity compared to row crops, while cover crops had significantly higher volumetric heat capacity compared to no cover crops. Thermal diffusivity was significantly higher in row crops compared to perennial biofuel and also significantly higher in no cover crop compared to cover crops at all pressures measured.

Cover crops have been advocated for their ability to improve soil health and crop productivity. In addition, the current study demonstrates the influence of cover crops on soil thermal properties. Cover crops can buffer excessive soil heat and this can help increase crop productivity. Furthermore, increasing concerns over climate variability have led to alternate biofuel sources. Apart from providing cleaner energy, some of these biofuel crops can also influence soil thermal properties positively. Therefore, cover crops and biofuel crops can improve soil thermal properties and enable the soil to buffer against extreme temperature changes.

\section{ACKNOWLEDGEMENTS}

This study was partly funded by a regional collaborative project, 'Cropping Systems Coordinated Agricultural Project: Climate Change Mitigation, and Adaptation in Cornbased Cropping Systems'. The authors would like to thank the USDA-NIFA for the research grant (Award No. 2011-68002-30190). 


\section{REFERENCES}

Abu-Hamdeh, H.N. 2000. Effect of tillage treatments on soil thermal conductivity for some Jordanian clay loam and loam soils. Soil Tillage Res. 56:145-151. doi:10.1016/S01671987(00)00129-X.

Abu-Hamdeh, H.N., and R.C. Reeder. 2000. Soil thermal conductivity: Effects of density, moisture, salt concentrations, and organic matter. Soil Sci. Soc. Am. J. 64:12851290. doi:10.2136/sssaj2000.6441285x.

Abu-Hamdeh, N.H., A.I. Khdair, and R.C. Reeder. 2001. A comparison of two methods used to evaluate thermal conductivity for some soils. Intern. J. of Heat and Mass Transfer. 44: 1073-1078. doi:10.1016/S0017-9310(00)00144-7.

Abu-Hamdeh, N.H. 2003. Thermal properties of soils as affected by density and water content. Biosys. Eng. 86:97-102. doi:10.1016/S1537-5110(03)00112-0.

Adhikari P., R.P. Udawatta, and S.H. Anderson. 2014. Soil thermal properties under prairies, conservation buffers, and corn-soybean land use systems. Soil Sc. Soc. Am. J. 78:1977-1986 doi:10.2136/sssaj2014.02.0074.

Allmaras, R.R., H.H. Schomberg, C.L. Douglas, and T.H. Dao. 2000. Soil organic carbon sequestration potential of adopting conservation tillage in US croplands. J. of Soil and Water Conserv. 55:365-373.

Blanco-Canqui, H., M.M. Mikha, D.R. Presley, and M.M. Claassen. 2011. Addition of cover crops enhances no-till potential for improving soil physical properties. Soil Sci. Soc. Am. J. 75(4):1471- 1478. doi:10.2136/sssaj2010.0430.

Brady, N.C., and R.R. Weil. 2008. The nature and properties of soils. $14^{\text {th }}$ edition. Prentice Hall. 
Bristow, K.L., G.S. Campbell, and C. Calissendorff. 1993. Test of a heat-pulse probe for measuring changes in soil water content. Soil Sci. Soc. Am. J. 57:930 - 934. doi:10.2136/sssaj1993.03615995005700040008x

Bristow, K.L., G.J. Kluitenberg, and R. Horton. 1994a. Measurement of soil thermal properties with a dual-probe heat-pulse technique. Soil Sci. Soc. Am. J. 58:1288 1294. doi:10.2136/sssaj1994.03615995005800050002x.

Bristow, K.L., R.D. White, and G.J. Kluitenberg. 1994b. Comparison of single and dual probes for measuring soil thermal properties with transient heating. Aust. J. Soil Res. 32:447 - 464. doi:10.1071/SR9940447.

Bristow, K.L. 2002. Thermal conductivity. In: J.H. Dane and G.C. Topp, editors, Methods of soil analysis. Part 4. SSSA Book Ser. 5. SSSA, Madison, WI. p. 1209-1226. doi:10.2136/sssabookser5.4.c50.

Campbell, G.S., C. Calissendorff, and J.H. Williams. 1991. Probe for measuring soil specific heat using a heat-pulse method. Soil Sci. Soc. of Am. J. 55:291-293. doi:10.2136/sssaj1991.03615995005500010052x.

Dabney, S.M., J.A. Delgado, and D.W. Reeves. 2001. Using winter cover crops to improve soil and water quality. Commun. Soil Sci. Plant Anal. 32:1221-1250. doi:10.1081/CSS-100104110.

Dahiya, R., J. Ingwersen, and T. Streck. 2007. The effect of mulching and tillage on the water and temperature regimes of a loess soil: Experimental findings and modeling. Soil Tillage Res. 96:52-63. doi:10.1016/j.still.2007.02.004.

Daigh, A.L., M.J., Helmers, E., Kladivko, X., Zhou, R., Goeken, J., Cavdini, D., Barker, and J., Sawyer. 2014. Soil water during the drought of 2012 as affected by rye cover crops in fields in Iowa and Indiana. J. Soil Water Conserv. 69 (6):564-573. doi:10.2489/jswc.70.5.103A 
Dane, J.H., and J.W. Hopmans. 2002. Water retention and storage. p. 671-717. In J.H. Dane and G.C. Topp (ed.) Methods of Soil Analysis. Part 4: Physical Methods. SSSA Book. SSSA, Madison, WI.

de Vries, D.A. 1963. Thermal properties of soils. p. 210-235. In W.R. Van Wijk (ed.) Physics of plant environment. North-Holland Publ. Co., Amsterdam.

Franzluebbers, A.J. 2005. Soil organic carbon sequestration and agricultural greenhouse gas emissions in the southeastern USA. Soil and Till. Res. 83(1): 120-147. doi:10.1016/j.still.2005.02.012.

Fuentes, J.P., M. Flury, and D.F. Bezdicek. 2004. Hydraulic properties in a silt loam soil under natural prairie, conventional till, and no-till. Soil Sci. Soc. Am. J. 68:16791688. doi:10.2136/sssaj2004.1679.

Gee, G.W., and D. Or. 2002. Particle-size analysis. In: J.H. Dane and G.C. Topps, editors, Methods of soil analysis. Part 4. SSSA Book Ser. 5. SSSA, Madison, WI. p. 272-278. doi:10.2136/sssabookser5.4.c9.

Ghauman, B.S., and R. Lal. 1985. Thermal conductivity, thermal diffusivity, and thermal capacity of some Nigerian soils. Soil Sci. 139:74-80.

Gressel, J. 2008. Transgenics are imperative for biofuel crops. Pl. Sci. 174:246-263. doi:10.1016/j.plantsci.2007.11.009.

Grossman, R.B., and T.G. Reinsch. 2002. Bulk density and linear extensibility. In: J.H. Dane and G.C. Topps, editors, Methods of soil analysis. Part 4. SSSA Book Ser. 5. SSSA, Madison, WI. p. 201-228. doi:10.2136/sssabookser5.4.c9.

Haramoto, E.R., and E.R. Gallandt. 2004. Brassica cover cropping for weed management: A review. Renew. Agri. Food Syst. 19:187-198. doi: http://dx.doi.org/10.1079/RAFS200490. 
Hartwig, N.L., and H.U. Ammon. 2002. Cover crops and living mulches. Weed Sci. 50:688-699. doi: 10.1614/00431745(2002)050[0688:AIACCA]2.0.CO;2

Haruna, S.I., and N.V. Nkongolo. 2015. Effects of tillage, rotation and cover crop on the physical properties of a silt-loam soil. Intern. Agrophys. 29:137-145. doi: 10.1515/intag-2015-0030

Haruna, S.I., S.H. Anderson, N.V. Nkongolo, and S. Zaibon. 2017. Soil hydraulic properties: Influence of cover crops and tillage. In press.

Heaton E.A., J. Clifton-Brown, T.B. Voigt, M.B. Jones, and S.P. Long. 2004. Miscanthus for renewable energy generation: European Union experience and projections for Illinois. Mitigation and Adaptation Strategies for Global Change 9:433-451.

Heitman, J.L., R. Horton, T. Ren, and T.E. Ochsner. 2007. An improved approach for measurement of coupled heat and water transfer in soil cells. Soil Sci. Soc. Am. J. 71:872-880. doi:10.2136/sssaj2006.0327

Heitman, J.L., R. Horton, T.J. Sauer, and T.M. DeSutter. 2008. Sensible heat observations reveal soil-water evaporation dynamics. J. Hydromet. 9:165-171. doi: http://dx.doi.org/10.1175/2007JHM963.1

Hopmans, J.W., J. Šimunek, and K.L. Bristow. 2002. Indirect estimation of soil thermal properties and water flux using heat pulse probe measurements: Geometry and dispersion effects. Water Res. Research. 38:1-14. doi: 10.1029/2000WR000071.

Jones M.B., and M. Walsh. 2001 Miscanthus for Energy and Fiber. James and James Ltd., London. 
Ju, Z., T. Ren, and C. Hu. 2011. Soil thermal conductivity as influenced by aggregation at intermediate water contents. Soil Sci. Soc. Am. J. 75:26-29. doi:10.2136/sssaj2010.0050N.

Jury, W.A., R. Horton. 2004. Soil physics. John Wiley \& Sons.

Jury, W.A., and E.E. Miller. 1974. Measurement of the transport coefficients for coupled flow of heat and moisture in a medium sand. Soil Sci. Soc. of Am. J. 38:551-557. doi:10.2136/sssaj1974.03615995003800040013x.

Kaspar, T.C., and W.L. Bland. 1992. Soil temperature and root growth. Soil Sc. 154:290299.

Khanna M.,B. Dhungana, and J. Clifton-Brown. 2008. Costs of producing miscanthus and switchgrass for bioenergy in Illinois. Biomass and Bioenergy 32:482-493. doi:10.1016/j.biombioe.2007.11.003.

Kluitenberg, G.J., K.L. Bristow, and B.S. Das. 1995. Error analysis of the heat pulse method for measuring soil heat capacity, diffusivity and conductivity. Soil Sci. Soc. Am. J. 59: 719 - 726. doi:10.2136/sssaj1995.03615995005900030013x.

Kuo, S., U.M. Sainju, and E.J. Jellum. 1997. Winter cover crop effects on soil organic carbon and carbohydrate in soil. Soil Sci. Soc. of Am. J. 61:145-152. doi:10.2136/sssaj1997.03615995006100010022x.

Lal, R. 2004. Soil carbon sequestration impacts on global climate change and food security. Science. 304:1623-1627. doi: 10.1126/science.1097396.

Ma, Z., C.W. Wood, and D.I. Bransby. 2000. Impacts of soil management on root characteristics of switchgrass. Biomass Bioenergy 18:105-112. doi:10.1016/S0961-9534(99)00076- 8 . 
MacDonald, N.W., D.R. Zac, and K.S. Pregitzer. 1995. Temperature effects on kinetics of microbial respiration and net nitrogen and sulfur mineralization. Soil Sci. Soc. Am. J. 59:233-240. doi:10.2136/sssaj1995.03615995005900010036x.

Mann, J.J., J.N. Barney, G.B. Kyser, and J.M. DiTomaso. 2012. Root System Dynamics of Miscanthus $\times$ giganteus and Panicum virgatum in Response to Rainfed and Irrigated Conditions in California. BioEnergy Res. 6:678-687. doi:10.1007/s12155-012-9287-y

McLaughlin, S.B., and L.A. Kszos. 2005. Development of switchgrass (Panicum virgatum) as a bioenergy feedstock in the United States. Biomass and Bioenergy 28:515-535. doi:10.1016/j.biombioe.2004.05.006.

Mishra, A., S.D. Sharma, and G.H. Khan. 2003. Improvement in physical and chemical properties of sodic soil by 3, 6, and 9 year old plantations of Eucalyptus tereticornis: Biorejuvenation of soil. For. Ecol. Manage. 184:115-124. doi:10.1016/S0378-1127(03)00213-5.

Mitchell, A.R., T.R. Ellsworth, and B.D. Meek. 1995. Effect of root systems on preferential flow in swelling soil. Commun. Soil Sci. Plant Anal. 26:2655-2666. doi:10.1080/00103629509369475.

Mori, Y., J.W. Hopmans, A.P. Mortensen, and G.J. Kluitenberg. 2003. Multifunctional heat pulse probe for the simultaneous measurement of soil water content, solute concentration and heat transport parameters. Vadose Zone J. 2:561-571. doi:10.2136/vzj2003.5610.

Murphy, B., T. Koen, B. Jones, and L. Huxedurp. 1993. Temporal variation of hydraulic properties for some soils with fragile structure. Soil Res. 31:179-197. doi:10.1071/SR9930179. 
Ochsner, T.E., R. Horton, and T. Ren. 2001. A new perspective on soil thermal properties. Soil Sci. Soc. Am. J. 65:1641-1647. doi:10.2136/sssaj2001.1641.

Parrish, D.J., and J.H. Fike. 2005. The biology and agronomy of switchgrass for biofuels. Crit. Rev. in Pl. Sci. 24:423-459. doi:10.1080/07352680500316433.

Post, W.M., and K.C. Kwon. 2000. Soil carbon sequestration and land-use change: processes and potential. Global. Change. Biol. 6:317-327. doi:10.1046/j.13652486.2000.00308.x.

Potter, K.N., R.M. Cruse, and R. Horton. 1985. Tillage effects on soil thermal properties. Soil Sci. Soc. Am. J. 49:968-973. doi:10.2136/sssaj1985.03615995004900040035x.

Pyter R., T.B. Voigt, E.A. Heaton, F.G. Dohleman, and S.P. Long. 2007. Giant miscanthus: Biomass crop for Illinois. In: Issues in New Crops and New Uses. J. Janick and A. Whipkey, editors. pp. 39-42. ASHS Press, Alexandria, VA.

Ren, T., K. Noborio, and R. Horton. 1999. Measuring soil water content, electrical conductivity, and thermal properties with a thermo-time domain reflectometry probe. Soil Sci. Soc. Am. J. 63: 450-457. doi:10.2136/sssaj1999.03615995006300030005x.

Sainju, U.M., and B.P. Singh. 2008. Nitrogen storage with cover crops and nitrogen fertilization in tilled and non-tilled soils. Agron. J. 100:619-627. doi:10.2134/agronj2007.0236.

Sanderson, M.A., P.R. Adler, A.A. Boateng, M.D. Casler, and G. Sarath. 2007. Switchgrass as a biofuels feedstock in the USA. Can. J. Plant Sci. 86:1315-1325.

SAS Institute. 2013. User's guide; Statistics. SAS Inst., Cary, NC.

Shukla, M.K. 2014. Soil physics: An introduction. CRC Press. 
Singer, J.W., S.M. Nusser, amd C.J. Alf. 2007. Are cover crops being used in the US corn belt? T. Soil Water Conserv. 65:353-358.

Stewart R.J., Y. Toma, F.G. Fernandez, A. Nishiwaki, T. Yamada, and G.A. Bollero. 2009. The ecology and agronomy of Miscanthus sinensis, a species important to bioenergy crop development, in its native range in Japan: a review. GCB Bioenergy (1):126-153. doi: 10.1111/j.1757-1707.2009.01010.x.

Tufekcioglu, A., J.W. Raich, T.M. Isenhart, and R.C. Schultz. 1998. Fine root dynamics, coarse root biomass, root distribution, and soil respiration in a multispecies riparian buffer in Central Iowa, USA. Agrofor. Syst. 44:163-174.

Usowicz, B., J. Lipiec, and A. Ferrero. 2009. Thermal properties in relation to soil water status in sloping vineyard. Teka Kom. Ochr. Kszt. Środ. Przyr. 6:386-410.

Villamil, M.B., G.A. Bollero, R.G. Darmody, F.W. Simmons, and D.G. Bullock. 2006. No-Till Corn/Soybean Systems Including Winter Cover Crops. Soil Sci. Soc. Am. J. 70:1936. doi:10.2136/sssaj2005.0350.

Vogel, K.P. 2004. Switchgrass. p. 561-588 In: L.E. Moser et al., eds. Warm-season (C4) Grasses. ASA-CSSA-SSSA, Madison, WI.

Vos, J.G.M., and N. Sumarni. 1997. Integrated crop management of hot pepper (Capsicum spp.) under tropical lowland conditions: effects of mulch on crop performance and production. J. Hort. Sci. 72:415- 424. doi:10.1080/14620316.1997.11515529.

Wagger, M.G., and D.B. Mengel. 1988. The role of nonleguminous cover crops in the efficient use of water and nutrients. In W.L Hargrove (ed.) Cropping strategies for efficient use of water and nitrogen. P. 115-127. ASA, CSSA, and SSSA, Madison, WI. 
West, T.O., and W.M. Post. 2002. Soil organic carbon sequestration rates by tillage and crop rotation. Soil Sci. Soc. of Am. J. 66:1930-1946. doi:10.2136/sssaj2002.1930.

Wierenga, P.J., D.R. Nielsen, R. Horton, and B. Kies. 1982. Tillage effects on soil temperature and thermal conductivity. Soil Sci. Soc. Am. J .69-90. doi:10.2134/asaspecpub44.c5.

Wierenga, P.J., D.R. Nielsen, and R.M. Hagan. 1969. Thermal properties of soil based upon field and laboratory measurements. Soil Sci. Soc. Am. Proc. 33:354-360. doi:10.2136/sssaj1969.03615995003300030009x.

Yadav, M.R., and G.S. Saxena. 1973. Effect of compaction and moisture content on specific heat and thermal capacity of soils. J. Indian Soc. Soil Sci. 21:129-132.

Yamanaka, T., A. Takeda, and J. Shimada. 1998. Evaporation beneath the soil surface: some observational evidence and numerical experiments. Hydrol.

Process.12:2193-2203. doi: 10.1002/(SICI)1099-

1085(19981030)12:13/14<2193::AID-HYP729>3.0.CO;2-P

Zaibon, S., S.H. Anderson, N.R., Kitchen, and S.I. Haruna. 2016. Soil hydraulic properties affected by topsoil thickness in cultivated switchgrass and cornsoybean rotation production systems. Soil Sci. Soc. Am. J. doi:10.2136/sssaj2016.04.0111 


\section{LIST OF FIGURES}

Figure 5.1. Thermal conductivity $(\lambda)$ for cover crop (CC), no cover crop (NC), giant miscanthus (GM) and switchgrass (SG) treatments at three depths (0-10, 10-20, and 20$30 \mathrm{~cm})$ and four soil water pressures $(0,-33,-100$, and $-300 \mathrm{kPa})$.

Figure 5.2. Volumetric heat capacity $\left(C_{V}\right)$ for cover crop (CC), no cover crop (NC), giant miscanthus (GM) and switchgrass (SG) treatments at three depths (0-10, 10-20, and 20$30 \mathrm{~cm})$ and four soil water pressures $(0,-33,-100$, and $-300 \mathrm{kPa})$.

Figure 5.3. Thermal diffusivity $(D)$ for cover crop (CC), no cover crop (NC), giant miscanthus (GM) and switchgrass (SG) treatments at three depths (0-10, 10-20, and 20$30 \mathrm{~cm})$ and four soil water pressures $(0,-33,-100$, and $-300 \mathrm{kPa})$. 
Table 5.1 Soil textural properties as a function of soil depth for the study site (Mexico silt loam).

\begin{tabular}{|c|c|c|c|c|}
\hline Depth & Horizon & Sand & Silt & Clay \\
\hline & & -----. & $\%$ & $\ldots$ \\
\hline $0-10$ & Ap & 5.4 & 75.9 & 18.7 \\
\hline $10-20$ & Ap & 4.8 & 77.2 & 18.0 \\
\hline $20-30$ & Btg1 & 4.6 & 71.9 & 23.5 \\
\hline
\end{tabular}


Table 5.2 Soil organic carbon (SOC), bulk density (Db) and volumetric water content (at selected water pressures).

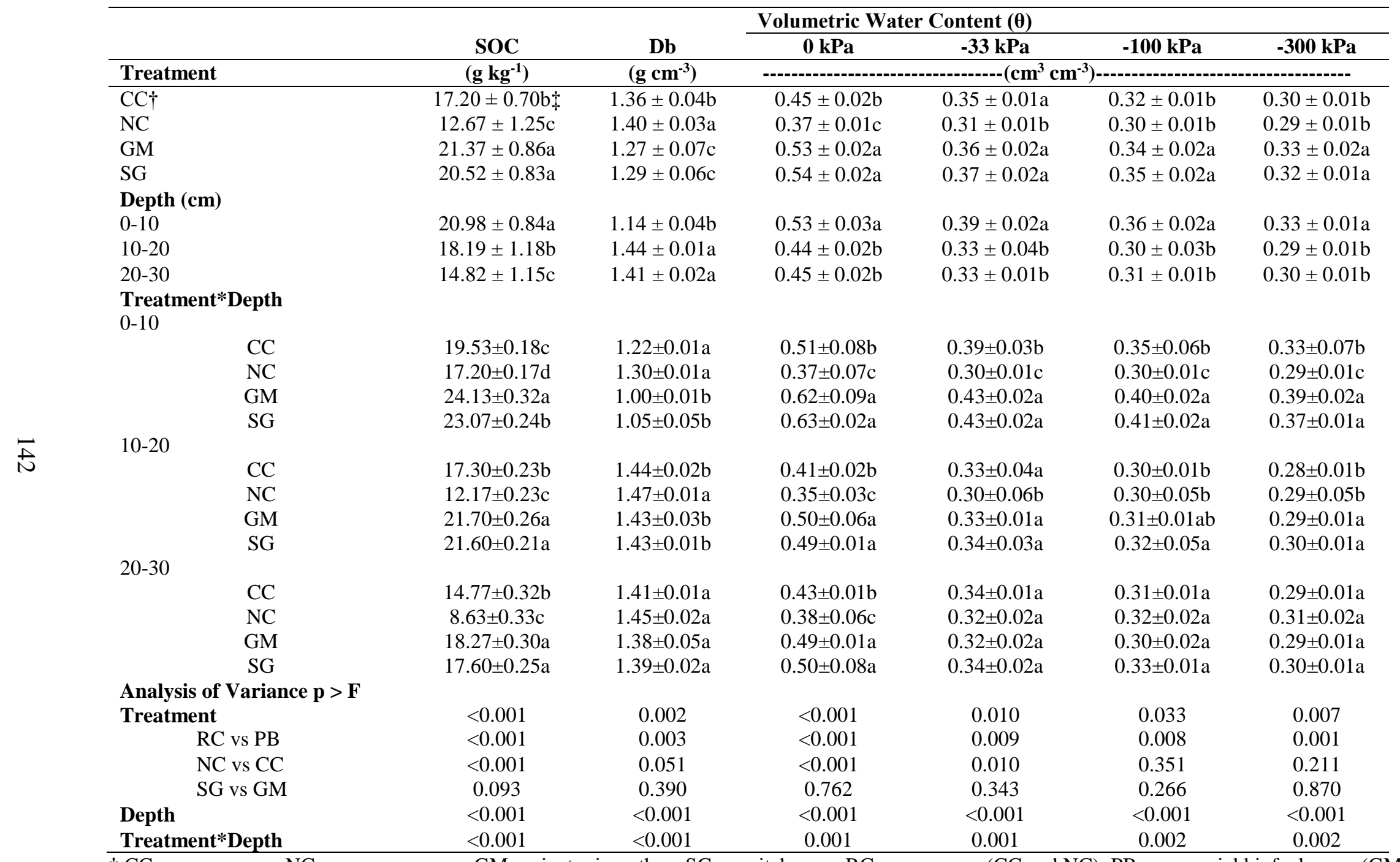

$\dagger \mathrm{CC}=$ cover crops; $\mathrm{NC}=$ no cover crops; $\mathrm{GM}=$ giant miscanthus; $\mathrm{SG}=$ switchgrass; $\mathrm{RC}=$ row crops $(\mathrm{CC}$ and $\mathrm{NC})$; $\mathrm{PB}=$ perennial biofuel crops $(\mathrm{GM}$ and SG). Treatment*Depth $=$ treatment by depth interaction.

$\$$ Mean \pm standard error. Means with different letters for a soil property are significantly different at the 0.05 probability level. 
Table 5.3 Thermal conductivity $(\lambda)$, volumetric heat capacity $\left(C_{V}\right)$ and thermal diffusivity $(D)$ at selected water pressures.

\begin{tabular}{|c|c|c|c|c|c|c|c|c|c|c|c|c|}
\hline \multirow{2}{*}{ Treatment mean } & \multicolumn{3}{|c|}{$0 \mathrm{kPa}$} & \multicolumn{3}{|c|}{$-33 \mathrm{kPa}$} & \multicolumn{3}{|c|}{$-100 \mathrm{kPa}$} & \multicolumn{3}{|c|}{$-300 \mathrm{kPa}$} \\
\hline & $\begin{array}{l}\lambda\left(\mathbf{W} \mathbf{m}^{-1}\right. \\
\left.\mathbf{K}^{-1}\right)\end{array}$ & $\begin{array}{l}C_{V}(\mathbf{M J} \\
\left.\mathbf{m}^{-3} \mathbf{K}^{-1}\right)\end{array}$ & $\begin{array}{l}D\left(\mathrm{~mm}^{2}\right. \\
\left.\mathrm{s}^{-1}\right)\end{array}$ & $\begin{array}{l}\lambda(\mathbf{W} \\
\left.\mathbf{m}^{-1} \mathbf{K}^{-1}\right)\end{array}$ & $\begin{array}{l}C_{V}(\mathbf{M J} \\
\left.\mathbf{m}^{-3} \mathbf{K}^{-1}\right)\end{array}$ & $\begin{array}{l}D\left(\mathrm{~mm}^{2}\right. \\
\left.\mathrm{s}^{-1}\right)\end{array}$ & $\begin{array}{l}\lambda\left(\mathbf{W} \mathrm{m}^{-}\right. \\
\left.{ }^{1} \mathbf{K}^{-1}\right)\end{array}$ & $\begin{array}{l}C_{V}(\mathrm{MJ} \\
\left.\mathbf{m}^{-3} \mathbf{K}^{-1}\right)\end{array}$ & $\begin{array}{l}D\left(\mathrm{~mm}^{2}\right. \\
\left.\mathrm{s}^{-1}\right)\end{array}$ & $\begin{array}{l}\lambda\left(\mathbf{W} \mathbf{m}^{-}\right. \\
\left.{ }^{1} \mathbf{K}^{-1}\right)\end{array}$ & $\begin{array}{l}C_{V}(\mathrm{MJ} \\
\left.\mathbf{m}^{-3} \mathbf{K}^{-1}\right)\end{array}$ & $\begin{array}{l}D\left(\mathrm{~mm}^{2}\right. \\
\left.\mathrm{s}^{-1}\right)\end{array}$ \\
\hline $\mathrm{CC} \dagger$ & $\begin{array}{l}1.34 \pm \\
0.01 \mathrm{at}\end{array}$ & $\begin{array}{c}3.56 \pm \\
0.05 b\end{array}$ & $\begin{array}{c}0.38 \pm \\
0.02 b\end{array}$ & $\begin{array}{c}1.18 \pm \\
0.02 \mathrm{a}\end{array}$ & $\begin{array}{c}3.07 \pm \\
0.02 \mathrm{a}\end{array}$ & $\begin{array}{c}0.38 \pm \\
0.01 b\end{array}$ & $\begin{array}{l}1.13 \pm \\
0.02 \mathrm{ab}\end{array}$ & $\begin{array}{l}3.07 \pm \\
0.02 \mathrm{ba}\end{array}$ & $\begin{array}{c}0.37 \pm \\
0.01 b\end{array}$ & $\begin{array}{c}1.12 \pm \\
0.02 \mathrm{a}\end{array}$ & $\begin{array}{l}3.04 \pm \\
0.01 b\end{array}$ & $\begin{array}{c}0.37 \pm \\
0.01 \mathrm{~b}\end{array}$ \\
\hline $\mathrm{NC}$ & $\begin{array}{l}1.37 \pm \\
0.01 \mathrm{a}\end{array}$ & $\begin{array}{c}3.11 \pm \\
0.01 \mathrm{c}\end{array}$ & $\begin{array}{c}0.44 \pm \\
0.03 \mathrm{a}\end{array}$ & $\begin{array}{l}1.19 \pm \\
0.01 \mathrm{a}\end{array}$ & $\begin{array}{l}2.57 \pm \\
0.01 \mathrm{~b}\end{array}$ & $\begin{array}{c}0.46 \pm \\
0.01 \mathrm{a}\end{array}$ & $\begin{array}{l}1.16 \pm \\
0.01 \mathrm{a}\end{array}$ & $\begin{array}{l}2.57 \pm \\
0.01 \mathrm{~b}\end{array}$ & $\begin{array}{c}0.45 \pm \\
0.03 \mathrm{a}\end{array}$ & $\begin{array}{c}1.13 \pm \\
0.01 \mathrm{a}\end{array}$ & $\begin{array}{c}2.55 \pm \\
0.03 \mathrm{c}\end{array}$ & $\begin{array}{c}0.44 \pm \\
0.01 \mathrm{a}\end{array}$ \\
\hline GM & $\begin{array}{l}1.17 \pm \\
0.02 \mathrm{c}\end{array}$ & $\begin{array}{l}3.79 \pm \\
0.03 \mathrm{a}\end{array}$ & $\begin{array}{l}0.31 \pm \\
0.03 \mathrm{~d}\end{array}$ & $\begin{array}{l}1.10 \pm \\
0.02 \mathrm{~b}\end{array}$ & $\begin{array}{l}3.06 \pm \\
0.02 \mathrm{a}\end{array}$ & $\begin{array}{c}0.36 \pm \\
0.01 \mathrm{c}\end{array}$ & $\begin{array}{l}1.07 \pm \\
0.02 \mathrm{c}\end{array}$ & $\begin{array}{l}3.07 \pm \\
0.02 \mathrm{a}\end{array}$ & $\begin{array}{c}0.35 \pm \\
0.01 \mathrm{c}\end{array}$ & $\begin{array}{l}1.07 \pm \\
0.02 \mathrm{a}\end{array}$ & $\begin{array}{l}3.06 \pm \\
0.01 \mathrm{ab}\end{array}$ & $\begin{array}{c}0.35 \pm \\
0.01 \mathrm{c}\end{array}$ \\
\hline SG & $\begin{array}{l}1.28 \pm \\
0.02 \mathrm{~b}\end{array}$ & $\begin{array}{c}3.73 \pm \\
0.01 \mathrm{a}\end{array}$ & $\begin{array}{c}0.34 \pm \\
0.04 \mathrm{c}\end{array}$ & $\begin{array}{l}1.14 \pm \\
0.02 \mathrm{~b}\end{array}$ & $\begin{array}{c}3.13 \pm \\
0.02 \mathrm{a}\end{array}$ & $\begin{array}{c}0.36 \pm \\
0.01 \mathrm{c}\end{array}$ & $\begin{array}{l}1.11 \pm \\
0.03 \mathrm{bc}\end{array}$ & $\begin{array}{c}3.13 \pm \\
0.01 \mathrm{a}\end{array}$ & $\begin{array}{l}0.35 \pm \\
0.01 \mathrm{bc}\end{array}$ & $\begin{array}{l}1.10 \pm \\
0.03 \mathrm{ab}\end{array}$ & $\begin{array}{c}3.10 \pm \\
0.01 \mathrm{a}\end{array}$ & $\begin{array}{l}0.35 \pm \\
0.01 \mathrm{bc}\end{array}$ \\
\hline \multicolumn{13}{|l|}{ Depth mean $(\mathrm{cm})$} \\
\hline $0-10$ & $\begin{array}{l}1.30 \pm \\
0.02 \mathrm{a}\end{array}$ & $\begin{array}{l}3.59 \pm \\
0.09 \mathrm{a}\end{array}$ & $\begin{array}{l}0.37 \pm \\
0.02 \mathrm{ab}\end{array}$ & $\begin{array}{l}1.16 \pm \\
0.02 \mathrm{a}\end{array}$ & $\begin{array}{c}2.99 \pm \\
0.07 \mathrm{a}\end{array}$ & $\begin{array}{l}0.39 \pm \\
0.02 \mathrm{ab}\end{array}$ & $\begin{array}{l}1.12 \pm \\
0.02 b\end{array}$ & $\begin{array}{c}2.98 \pm \\
0.07\end{array}$ & $\begin{array}{l}0.38 \pm \\
0.01 \mathrm{ab}\end{array}$ & $\begin{array}{l}1.10 \pm \\
0.02 \mathrm{ab}\end{array}$ & $\begin{array}{c}2.95 \pm \\
0.07\end{array}$ & $\begin{array}{l}0.38 \pm \\
0.01 \mathrm{ab}\end{array}$ \\
\hline $10-20$ & $\begin{array}{l}1.31 \pm \\
0.02 \mathrm{a}\end{array}$ & $\begin{array}{c}3.57 \pm \\
0.08 \mathrm{a}\end{array}$ & $\begin{array}{c}0.37 \pm \\
0.02 \mathrm{a}\end{array}$ & $\begin{array}{l}1.18 \pm \\
0.02 \mathrm{a}\end{array}$ & $\begin{array}{c}2.96 \pm \\
0.07 \mathrm{a}\end{array}$ & $\begin{array}{c}0.40 \pm \\
0.01 \mathrm{a}\end{array}$ & $\begin{array}{c}1.15 \pm \\
0.02 \mathrm{a}\end{array}$ & $\begin{array}{c}2.94 \pm \\
0.07\end{array}$ & $\begin{array}{c}0.39 \pm \\
0.01 \mathrm{a}\end{array}$ & $\begin{array}{c}1.13 \pm \\
0.02 \mathrm{a}\end{array}$ & $\begin{array}{c}2.94 \pm \\
0.07\end{array}$ & $\begin{array}{c}0.39 \pm \\
0.01 \mathrm{a}\end{array}$ \\
\hline $20-30$ & $\begin{array}{l}1.25 \pm \\
0.03 b\end{array}$ & $\begin{array}{l}3.49 \pm \\
0.04 \mathrm{~b}\end{array}$ & $\begin{array}{l}0.36 \pm \\
0.02 b\end{array}$ & $\begin{array}{l}1.13 \pm \\
0.02 \mathrm{~b}\end{array}$ & $\begin{array}{l}2.93 \pm \\
0.06 \mathrm{~b}\end{array}$ & $\begin{array}{l}0.39 \pm \\
0.01 \mathrm{~b}\end{array}$ & $\begin{array}{l}1.08 \pm \\
0.02 \mathrm{c}\end{array}$ & $\begin{array}{c}2.97 \pm \\
0.07\end{array}$ & $\begin{array}{c}0.44 \pm \\
0.01 \mathrm{~b}\end{array}$ & $\begin{array}{l}1.07 \pm \\
0.01 \mathrm{~b}\end{array}$ & $\begin{array}{c}2.92 \pm \\
0.07\end{array}$ & $\begin{array}{l}0.37 \pm \\
0.01 \mathrm{~b}\end{array}$ \\
\hline \multicolumn{13}{|c|}{ Analysis of Variance $p>F$} \\
\hline Treatment & 0.002 & $<0.001$ & $<0.001$ & 0.259 & $<0.001$ & 0.001 & 0.179 & $<0.001$ & 0.003 & 0.355 & $<0.001$ & 0.007 \\
\hline $\mathrm{RC}$ vs PB & 0.001 & $<0.001$ & $<0.001$ & 0.046 & $<0.001$ & 0.001 & 0.047 & $<0.001$ & 0.003 & 0.141 & $<0.001$ & 0.007 \\
\hline $\mathrm{NC}$ vs $\mathrm{CC}$ & 0.267 & $<0.001$ & $<0.001$ & 0.906 & $<0.001$ & 0.002 & 0.406 & $<0.001$ & 0.003 & 0.701 & $<0.001$ & 0.008 \\
\hline SG vs GM & 0.007 & 0.090 & 0.002 & 0.473 & 0.063 & 0.842 & 0.345 & 0.064 & 0.669 & 0.383 & 0.233 & 0.659 \\
\hline Depth & 0.002 & 0.010 & 0.031 & 0.010 & 0.009 & 0.090 & 0.001 & 0.062 & 0.015 & 0.004 & 0.491 & 0.053 \\
\hline Treatment*Depth & 0.728 & 0.086 & 0.071 & 0.552 & 0.156 & 0.541 & 0.871 & 0.246 & 0.769 & 0.493 & 0.757 & 0.682 \\
\hline
\end{tabular}

$\dagger \mathrm{CC}=$ cover crops; $\mathrm{NC}=$ no cover crops; $\mathrm{GM}=$ giant miscanthus; $\mathrm{SG}=$ switchgrass; $\mathrm{RC}=$ row crops $(\mathrm{CC}$ and $\mathrm{NC})$; $\mathrm{PB}=$ perennial biofuel crops $(\mathrm{GM}$ and SG). Treatment*Depth $=$ treatment by depth interaction.

$\ddagger$ Mean \pm standard error. Means with different letters for a soil property are significantly different at the 0.05 probability level. 
(a)

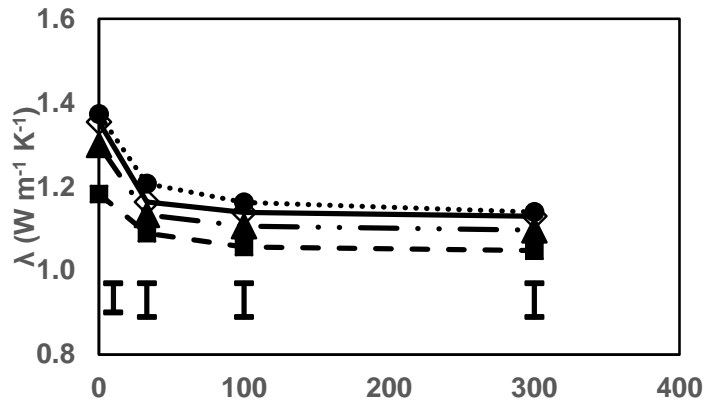

(b)

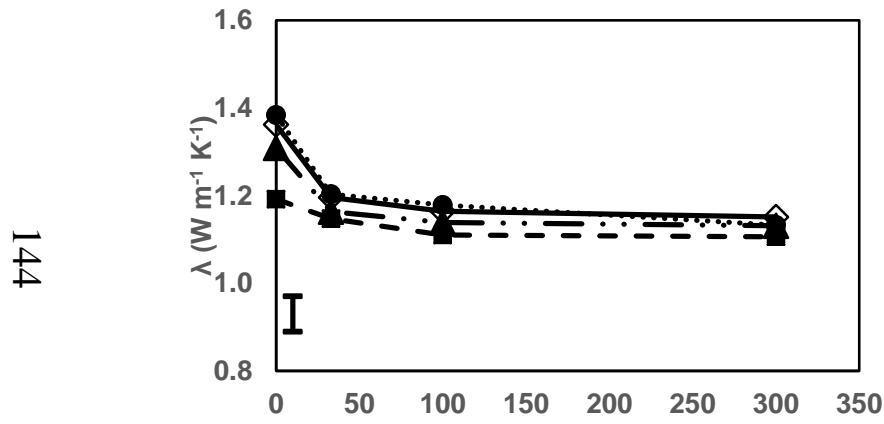

(c)

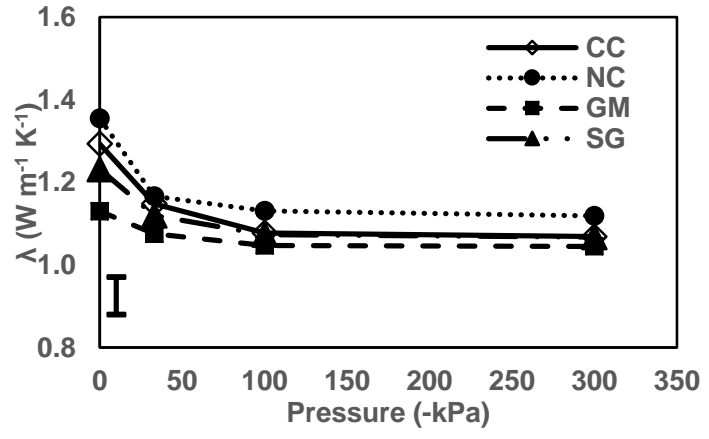

(d)

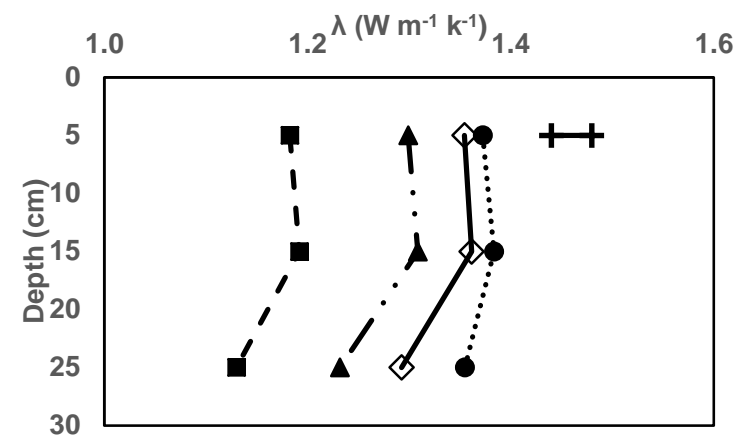

(f)

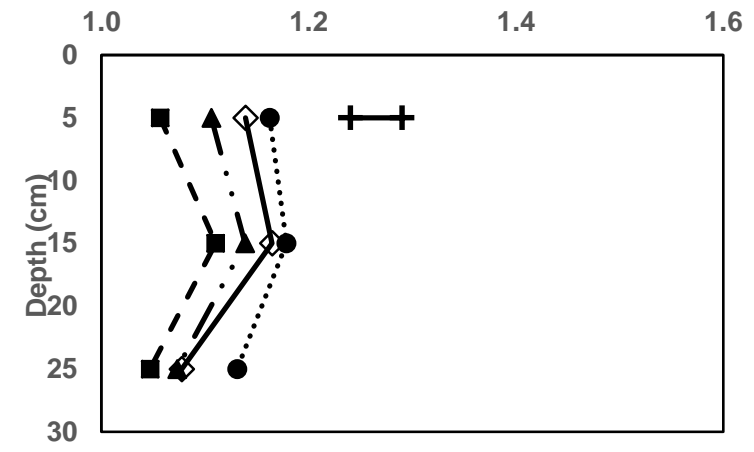

1.6

(g)

Figure 5.1 Thermal conductivity $(\lambda)$ for cover crop (CC), no cover crop (NC), giant miscanthus (GM) and switchgrass (SG) treatments at (a) 0-10 cm, (b) $10-20 \mathrm{~cm}$, (c) $20-30 \mathrm{~cm}$ depths and at four soil water pressures (d) 0, (e) -33, (f) -100 , and (g) $-300 \mathrm{kPa}$. Bar indicates least significant difference (LSD) at $\mathrm{p} \leq$ 0.05 for $\lambda$ among various treatments.

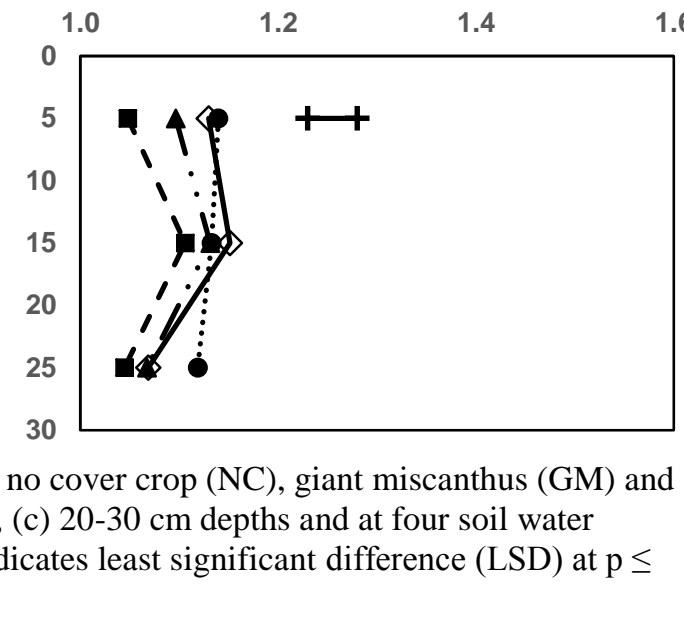

(e)

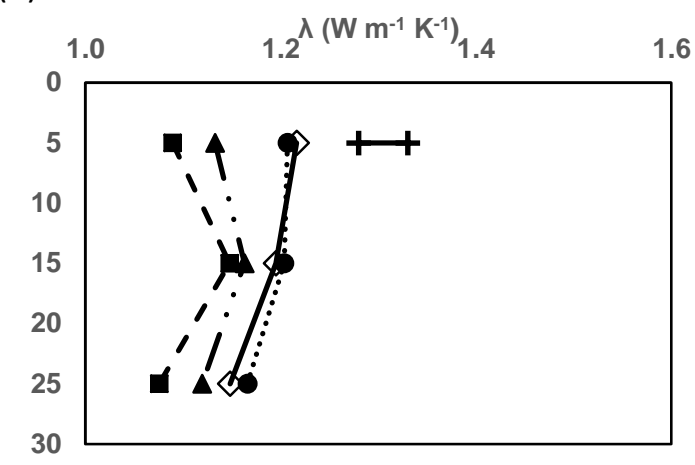


(a)

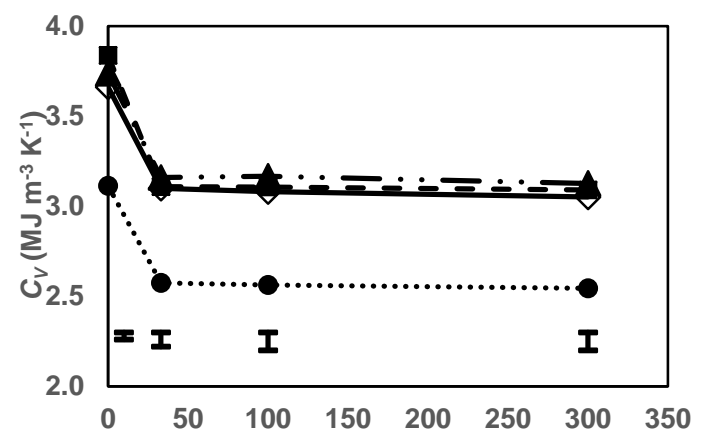

(b)

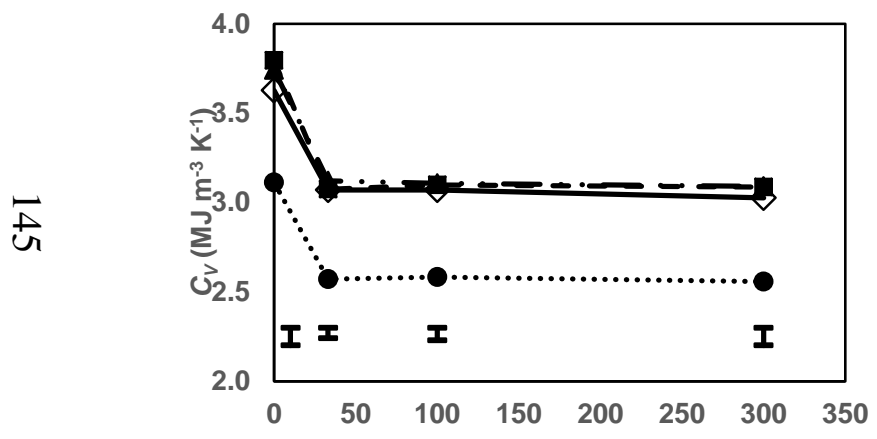

(c)

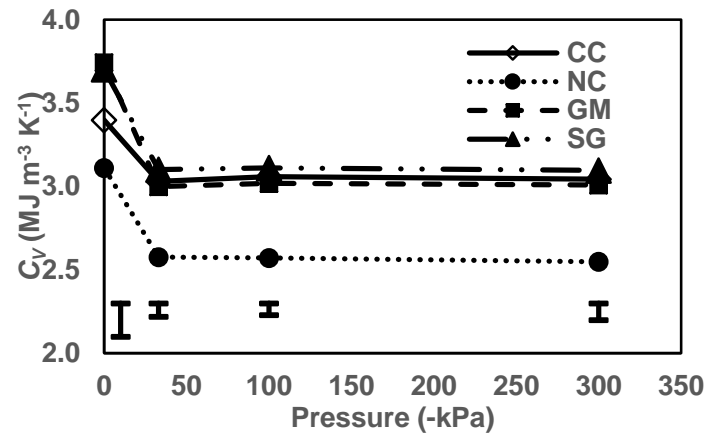

(d)

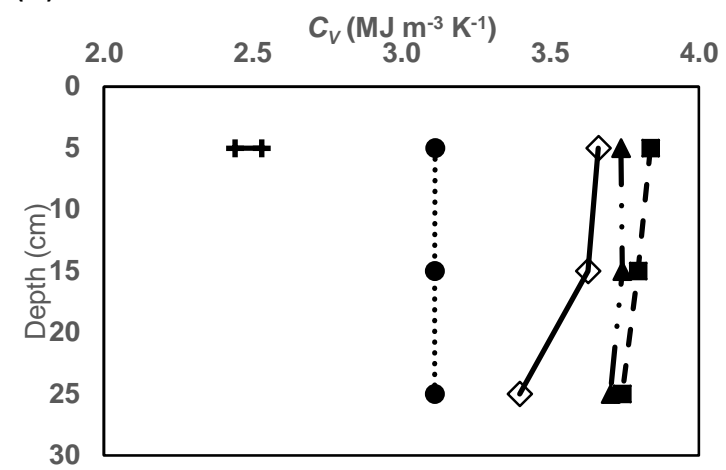

(f)

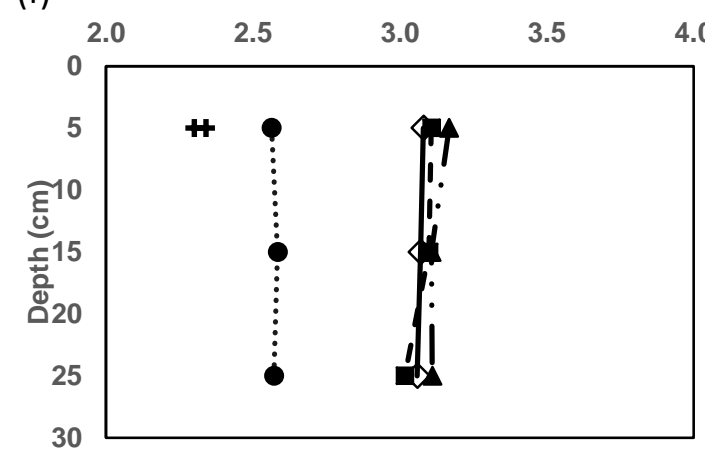

Figure 5.2 Volumetric heat capacity $\left(C_{V}\right)$ for cover crop (CC), no cover crop (NC), giant miscanthus (GM) and switchgrass (SG) treatments at (a) 0-10 cm, (b) 10-20 cm, (c) 20-30 cm depths and at four soil water pressures (d) 0, (e) -33 , (f) -100 , and (g) $-300 \mathrm{kPa}$. Bar indicates least square difference (LSD) at $\mathrm{p} \leq 0.05$ for $C_{V}$ among various treatments. (e)

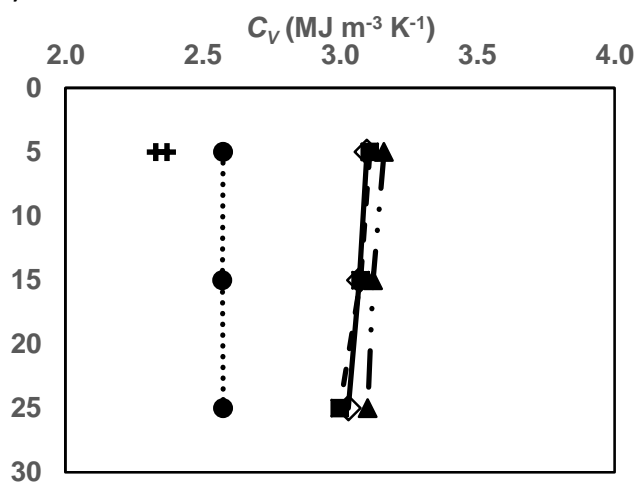

g)

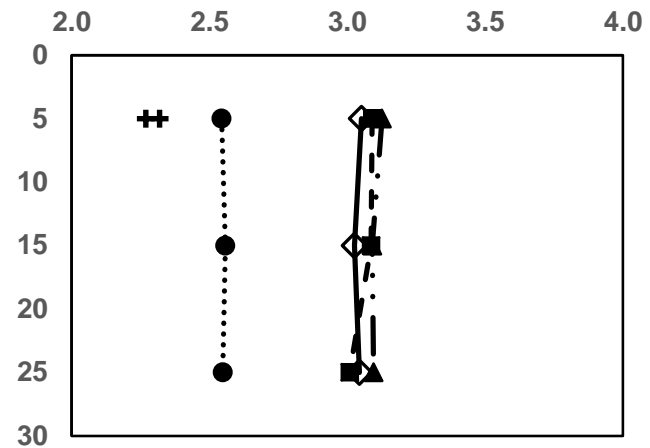

4.0 
(a)

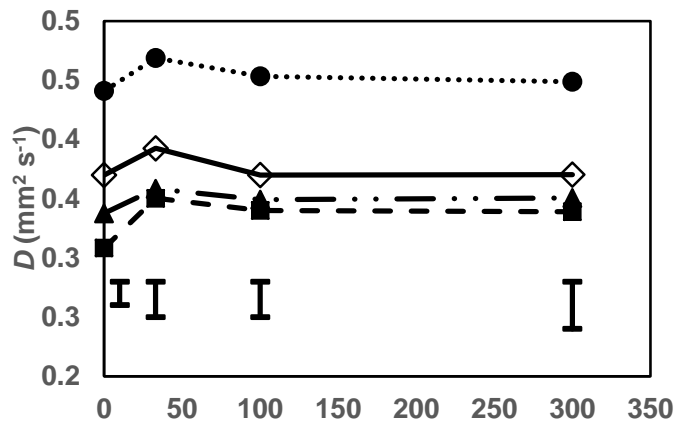

(b)

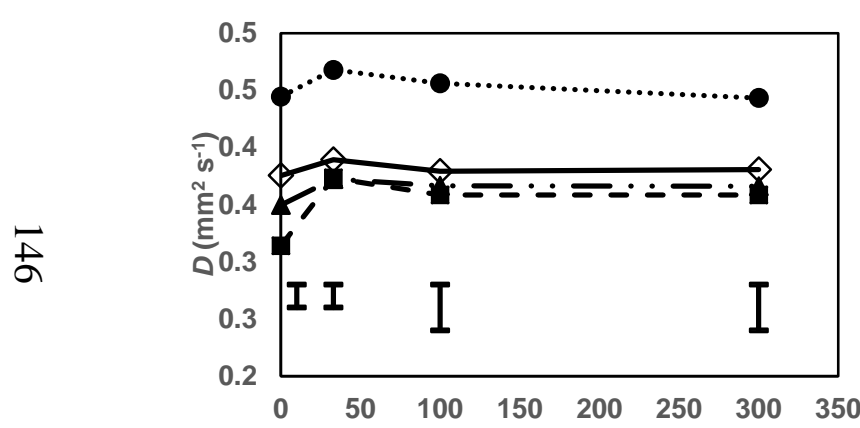

(c)

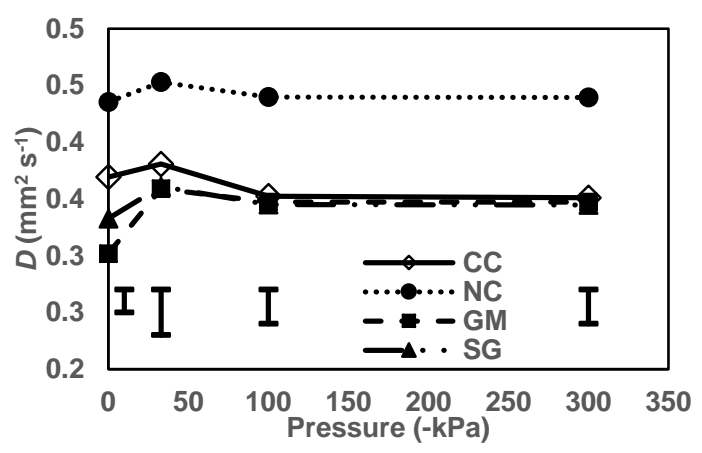

(d)

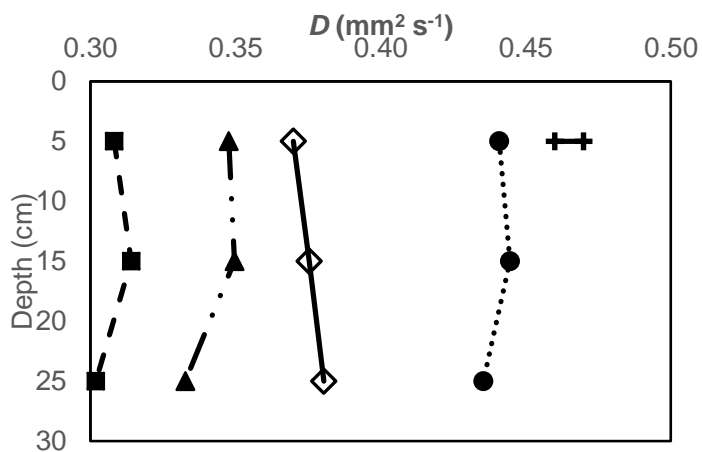

(f)

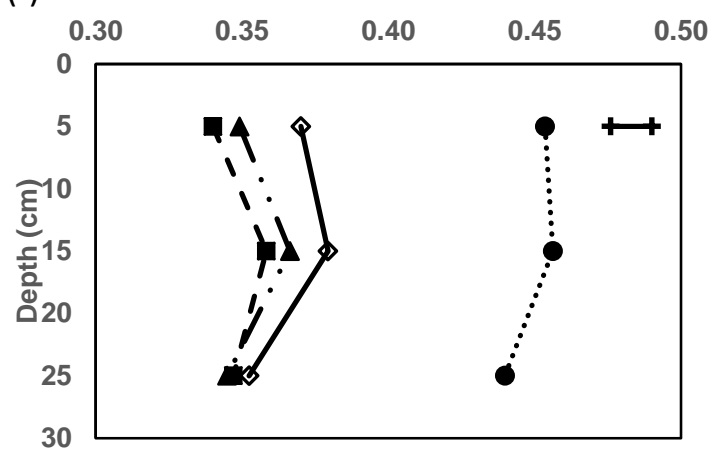

(g)
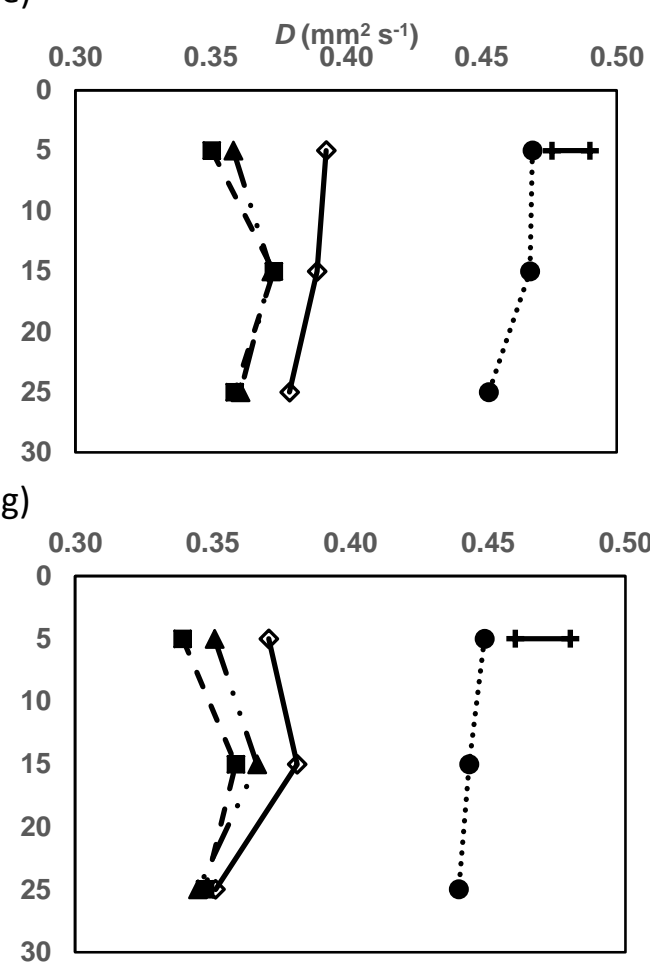

Figure 5.3 Thermal diffusivity $(D)$ for cover crop $(\mathrm{CC})$, no cover crop (NC), giant miscanthus (GM) and switchgrass (SG) treatments at (a) 0-10 cm, (b) 10-20 cm, (c) 20-30 cm depths and at four soil water pressures (d) 0, (e) -33 , (f) -100 , and (g) $-300 \mathrm{kPa}$. Bar indicates least significant difference (LSD) at $\mathrm{p} \leq$ 0.05 for $D$ among various treatments. 


\section{CHAPTER 6}

\section{CONCLUSIONS}

The effects of cover crops and tillage land management practices on soil physical and hydraulic properties were studied during 2014 and 2015. Two experimental sites were used: 1) Lincoln University Freeman Research Center, managed with continuous corn (Zea mays), cereal rye (Secale cereal) cover crop or no cover crop, with moldboard plow tillage or no tillage; and 2) University of Missouri Bradford Research Center, managed with perennial switchgrass (Panicum vergatum), miscanthus (Miscanthus $x$ gigantus), or continuous corn with and without cover crops [cereal rye, hairy vetch (Vicia villosa) and Austrian winter pea (Pisum sativum subsp. arvense)] with no tillage. Soils on the first site were Waldron silt loam (fine, smectitic, calcareous, mesic Aeric Fluvaquents) while soils on the second site were Mexico silt loam (fine, smectitic, mesic Vertic Epiaqualfs). Three studies were conducted for this research and the following specific conclusions were drawn from these experiments.

\section{Study 1: Soil Hydraulic Properties}

1. Tillage management caused significantly lower bulk density compared to no-till management right after tillage. Thus, volumetric water content at 0.0 and $-0.4 \mathrm{kPa}$ soil water pressure were significantly higher under tillage management compared to no-till management right after tillage. However, this trend did not last for one year.

2. Cover crops had significantly higher macroporosity (> 1,000 $\mu \mathrm{m}$ diameter) compared to no cover crop management, while tillage had significantly higher coarse mesoporosity (60$1,000 \mu \mathrm{m}$ diameter) compared to no-till right after tillage. A combination of cover crops 
and tillage also improved macroporosity. Pore sizes were not significantly different between both tillage systems after one year.

3. Tillage significantly improved saturated hydraulic conductivity $\left(K_{\text {sat }}\right)$ compared to no-till management right after tillage which was related to the significantly higher coarse mesoporosity observed under tillage management. However, this trend did not last for one year.

\section{Study 2: Ponded Infiltration}

1. During 2014 and 2015, Parlange and Green-Ampt models fit measured data well with most coefficients of variation near 0.99 .

2. In 2014 , the saturated hydraulic conductivity $\left(K_{S}\right)$ parameter values estimated from the Parlange and Green-Ampt models were $75 \%$ and $80 \%$ higher in cover crop management compared to no cover crop management, respectively.

3. In 2015 , results showed that the sorptivity $(S)$ parameter values estimated from the Parlange and Green-Ampt models were $82 \%$ and $90 \%$ higher in cover crop management compared to no cover crop management, respectively.

4. The quasi-steady infiltration rate $\left(q_{s}\right)$ and field saturated hydraulic conductivity $\left(K_{f s}\right)$ parameter values were significantly higher under cover crop compared to no cover crop management in 2014. Thus, cumulative infiltration was higher in cover crop management compared to no cover crop management. Cumulative infiltration was numerically higher under tillage compared to no-till management for both years of study.

\section{Study 3: Soil Thermal Properties}

1. After eight years of treatment, perennial biofuel crops (miscanthus and switchgrass) improved soil organic carbon (SOC) by $29 \%$ compared to row crop management (cover 
crops and no cover crops), while SOC was $26 \%$ higher in cover crop management compared to no cover crop management.

2. Soil bulk density was significantly higher in row crop management compared to perennial biofuel management, and numerically higher in no cover crop management compared to cover crop management.

3. Thermal conductivity and volumetric heat capacity decreased while thermal diffusivity increased with a change in pressure from saturation to $-33 \mathrm{kPa}$ soil water pressure for both row crop management and perennial biofuel crops treatments probably due to the water drainage between these pressures.

4. At saturation, row crop management had $10 \%$ higher thermal conductivity compared to perennial biofuel crops, while cover crops had 13\% higher volumetric heat capacity compared to no cover crops.

5. At all soil water pressures measured, perennial biofuel crops had significantly higher volumetric heat capacity compared to row crops, while cover crops had significantly higher volumetric heat capacity compared to no cover crops.

\section{SUMMARY}

For an alluvial soil, tillage management improved some hydraulic properties immediately after these operations. However, these improvements did not last over one year. This suggests that the effects of tillage in the context of changes in soil hydraulic

properties are often only immediate and may diminish with time. Results from this study also revealed that some hydraulic properties improved with a combination of both tillage and cover crop management practices. This study demonstrated that cover crops improved 
water infiltration due to their consumptive use of soil water early in the season. These effects may improve grain crop production in some years by enhancing water storage. The effects of cover crops will compensate for some of the challenges associated with tillage management effects on soil properties.

For a claypan soil, perennial biofuel and cover crops add organic carbon to soil and improve soil water retention - these properties can help buffer against temperature changes and reduce heat transport. These effects are beneficial for seed germination and microbial activity in soils. Over time, cover crops showed consistent positive effects on soil thermal properties.

Incorporating cover crops into crop production cycles can help reduce soil and nutrient loss by providing cover to intercept raindrop energy. Furthermore, the leaves of cover crops can intercept solar energy, which can buffer the soil; this can lead to a reduction in soil water evaporation and enhanced microbial activity. Leguminous cover crops can reduce the dependence on synthetic nitrogen fertilizers through atmospheric nitrogen fixation. Non-leguminous cover crops can help in recycling excess soil nitrate, and this can lead to better surface and ground water quality. The roots of cover crops can also reduce soil loss by holding soil particles in place. Cover crops may also add organic carbon lost due to annual tillage. The humus in organic carbon can bind soil particles together, thus improving aggregate stability and soil porosity. Earthworms find organic carbon palatable and higher organic carbon can lead to increased earthworm activity in soil. Increased earthworm activity can improve soil aeration and water infiltration through biopores generated by their activity. Therefore, cover crops can affect soil physical properties in various ways. Further studies will improve our understanding of these effects. 
This study demonstrated that cover crop management practices can improve some soil health indicators, specifically physical properties. These changes are important for improving crop productivity and environmental sustainability. However, due to the renewed interest in cover crops, more studies are needed to better quantify the short and long term effects of cover crops on soil physical and hydraulic properties. Such studies should ensure good management methods for cover crop establishment to maximize the beneficial effects of these cover crops. In order to ensure good establishment, winter cover crops may be seeded into the growing cash crop just before harvest. Cover crop management also requires a considerable length of time in order for the soil to equilibrate and for cover crops to provide these benefits. Therefore, future studies should include longer term experiments ( $>5$ years).

Currently, there are some inconsistencies in the results of cover crop studies done over several years. One of the reasons may be due to the increased variability in weather conditions during these studies. Therefore, there is a need to study the effects of weather conditions on cover crop density and how it affects soil physical properties. Soil type may also affect the influence of cover crops on soil physical properties associated with specific weather conditions. Further information on the effects of interactions between weather conditions and soils on cover crop growth and how these effect soil physical properties are also needed.

Besides improving cover crop density, there is a need to accurately quantify the soil pores generated by cover crop roots. These types of experiments will provide a better understanding of pore size distribution and connectivity. One of the ways to accurately quantify soil pore parameters is through the use of X-ray computed tomography (X-ray 
CT). X-ray CT can be used to effectively measure the shape, distribution and arrangement of pores generated by cover crops. 


\section{APPENDICES}




\section{Appendix 1}

A 1.1. Laboratory measurements for saturated hydraulic conductivity $\left(K_{\text {sat }}\right)$ and bulk density for soil cores measured in 2014 right after cover crop termination and spring tillage used in chapter 3. Till-CC=tillage with cover crop, Till-NC=tillage with no cover crop, NT-CC=no tillage with cover crop, NT-NC=no tillage with no cover crop, $\mathrm{PG}=$ Perennial grass (fescue).

\begin{tabular}{|c|c|c|c|c|}
\hline Treatment & Replicate & $\begin{array}{l}\text { Depth } \\
\text { (cm) }\end{array}$ & $\begin{array}{c}K_{\text {sat }} \\
\left(\mathbf{m m ~ h r}^{-1}\right)\end{array}$ & $\begin{array}{c}\text { Bulk Density } \\
\left(\mathrm{g} \mathrm{cm}^{-3}\right)\end{array}$ \\
\hline Till-CC & 1 & $0-10$ & 30.98 & 1.39 \\
\hline Till-CC & 2 & $0-10$ & 95.45 & 1.17 \\
\hline Till-CC & 3 & $0-10$ & 71.84 & 1.13 \\
\hline Till-NC & 1 & $0-10$ & 39.12 & 1.27 \\
\hline Till-NC & 2 & $0-10$ & 44.17 & 1.27 \\
\hline Till-NC & 3 & $0-10$ & 49.22 & 1.11 \\
\hline NT-CC & 1 & $0-10$ & 6.76 & 1.34 \\
\hline NT-CC & 2 & $0-10$ & 7.24 & 1.42 \\
\hline NT-CC & 3 & $0-10$ & 6.28 & 1.40 \\
\hline NT-NC & 1 & $0-10$ & 2.45 & 1.39 \\
\hline NT-NC & 2 & $0-10$ & 12.77 & 1.54 \\
\hline NT-NC & 3 & $0-10$ & 7.61 & 1.42 \\
\hline PG & 1 & $0-10$ & 42.44 & 1.28 \\
\hline PG & 2 & $0-10$ & 58.42 & 1.38 \\
\hline PG & 3 & $0-10$ & 26.45 & 1.41 \\
\hline Till-CC & 1 & $10-20$ & 69.69 & 1.58 \\
\hline Till-CC & 2 & $10-20$ & 6.56 & 1.48 \\
\hline Till-CC & 3 & $10-20$ & 25.51 & 1.46 \\
\hline Till-NC & 1 & $10-20$ & 29.59 & 1.69 \\
\hline Till-NC & 2 & $10-20$ & 19.10 & 1.43 \\
\hline Till-NC & 3 & $10-20$ & 24.35 & 1.32 \\
\hline NT-CC & 1 & $10-20$ & 6.48 & 1.50 \\
\hline NT-CC & 2 & $10-20$ & 2.71 & 1.56 \\
\hline NT-CC & 3 & $10-20$ & 1.46 & 1.59 \\
\hline NT-NC & 1 & $10-20$ & 1.56 & 1.56 \\
\hline NT-NC & 2 & $10-20$ & 1.74 & 1.60 \\
\hline NT-NC & 3 & $10-20$ & 1.37 & 1.64 \\
\hline PG & 1 & $10-20$ & 6.75 & 1.48 \\
\hline PG & 2 & $10-20$ & 3.80 & 1.53 \\
\hline PG & 3 & $10-20$ & 1.38 & 1.62 \\
\hline Till-CC & 1 & $20-30$ & 31.55 & 1.60 \\
\hline Till-CC & 2 & $20-30$ & 1.13 & 1.43 \\
\hline Till-CC & 3 & $20-30$ & 13.08 & 1.53 \\
\hline Till-NC & 1 & $20-30$ & 1.24 & 1.54 \\
\hline Till-NC & 2 & $20-30$ & 4.23 & 1.53 \\
\hline Till-NC & 3 & $20-30$ & 2.48 & 1.51 \\
\hline NT-CC & 1 & $20-30$ & 1.44 & 1.60 \\
\hline NT-CC & 2 & $20-30$ & 5.59 & 1.57 \\
\hline
\end{tabular}


A 1.1 cont'd

\begin{tabular}{ccccc}
\hline Treatment & Replicate & $\begin{array}{c}\text { Depth } \\
(\mathbf{c m})\end{array}$ & $\begin{array}{c}\boldsymbol{K}_{\text {sat }} \\
\left(\mathbf{m m} \mathbf{~ h r}^{-\mathbf{1}}\right)\end{array}$ & $\begin{array}{c}\text { Bulk Density } \\
\left(\mathbf{g ~ c m}^{-\mathbf{3}}\right)\end{array}$ \\
\hline NT-CC & 3 & $20-30$ & 3.49 & 1.43 \\
NT-NC & 1 & $20-30$ & 1.42 & 1.40 \\
NT-NC & 2 & $20-30$ & 1.44 & 1.66 \\
NT-NC & 3 & $20-30$ & 1.13 & 1.58 \\
PG & 1 & $20-30$ & 2.06 & 1.51 \\
PG & 2 & $20-30$ & 2.41 & 1.65 \\
PG & 3 & $20-30$ & 1.93 & 1.60 \\
Till-CC & 1 & $30-40$ & 23.84 & 1.65 \\
Till-CC & 2 & $30-40$ & 1.51 & 1.56 \\
Till-CC & 3 & $30-40$ & 1.62 & 1.53 \\
Till-NC & 1 & $30-40$ & 1.33 & 1.44 \\
Till-NC & 2 & $30-40$ & 4.20 & 1.45 \\
Till-NC & 3 & $30-40$ & 2.66 & 1.53 \\
NT-CC & 1 & $30-40$ & 1.24 & 1.50 \\
NT-CC & 2 & $30-40$ & 1.28 & 1.58 \\
NT-CC & 3 & $30-40$ & 1.32 & 1.35 \\
NT-NC & 1 & $30-40$ & 1.23 & 1.28 \\
NT-NC & 2 & $30-40$ & 1.47 & 1.44 \\
NT-NC & 3 & $30-40$ & 1.11 & 1.47 \\
PG & 1 & $30-40$ & 1.56 & 1.42 \\
PG & 2 & $30-40$ & 2.15 & 1.55 \\
PG & 3 & $30-40$ & 3.61 & 1.50 \\
\hline
\end{tabular}


A 1.2. Laboratory measurements for saturated hydraulic conductivity $\left(K_{\text {sat }}\right)$ and bulk density for soil cores measured in 2014 before cover crop termination used in chapter 3 . Till-CC=tillage with cover crop, Till-NC=tillage with no cover crop, NT-CC=no tillage with cover crop, NT-NC=no tillage with no cover crop.

\begin{tabular}{|c|c|c|c|c|}
\hline Treatment & Replicate & $\begin{array}{c}\text { Depth } \\
(\mathrm{cm})\end{array}$ & $\begin{array}{c}K_{\text {sat }} \\
\left(\mathbf{m m ~ h r}^{-1}\right)\end{array}$ & $\begin{array}{c}\text { Bulk Density } \\
\left(\mathrm{g} \mathrm{cm}^{-3}\right)\end{array}$ \\
\hline Till-CC & 1 & $0-10$ & 6.80 & 1.43 \\
\hline Till-CC & 2 & $0-10$ & 1.73 & 1.46 \\
\hline Till-CC & 3 & $0-10$ & 9.93 & 1.35 \\
\hline Till-NC & 1 & $0-10$ & 47.52 & 1.48 \\
\hline Till-NC & 2 & $0-10$ & 25.89 & 1.36 \\
\hline Till-NC & 3 & $0-10$ & 4.26 & 1.42 \\
\hline NT-CC & 1 & $0-10$ & 101.76 & 1.50 \\
\hline NT-CC & 2 & $0-10$ & 2.15 & 1.45 \\
\hline NT-CC & 3 & $0-10$ & 6.82 & 1.47 \\
\hline NT-NC & 1 & $0-10$ & 1.35 & 1.27 \\
\hline NT-NC & 2 & $0-10$ & 5.53 & 1.45 \\
\hline NT-NC & 3 & $0-10$ & 10.16 & 1.43 \\
\hline Till-CC & 1 & $10-20$ & 2.70 & 1.50 \\
\hline Till-CC & 2 & $10-20$ & 1.16 & 1.47 \\
\hline Till-CC & 3 & $10-20$ & 2.50 & 1.64 \\
\hline Till-NC & 1 & $10-20$ & 1.16 & 1.54 \\
\hline Till-NC & 2 & $10-20$ & 1.95 & 1.50 \\
\hline Till-NC & 3 & $10-20$ & 5.36 & 1.47 \\
\hline $\mathrm{NT}-\mathrm{CC}$ & 1 & $10-20$ & 61.49 & 1.63 \\
\hline NT-CC & 2 & $10-20$ & 5.32 & 1.57 \\
\hline NT-CC & 3 & $10-20$ & 1.38 & 1.65 \\
\hline NT-NC & 1 & $10-20$ & 1.10 & 1.49 \\
\hline NT-NC & 2 & $10-20$ & 1.26 & 1.55 \\
\hline NT-NC & 3 & $10-20$ & 1.18 & 1.62 \\
\hline
\end{tabular}


A 1.3. Volumetric water content $\left(\mathrm{cm}^{3} \mathrm{~cm}^{-3}\right)$ values for soil cores at $0,-0.4,-1.0,-2.5,-5.0,-10.0,-20.0,-33.0,-100.0$, and -1500.0 $\mathrm{kPa}$ soil water pressure measured in 2014 right after cover crop termination and spring tillage used in chapter 3. Till-CC=tillage with cover crop, Till-NC=tillage with no cover crop, NT-CC=no tillage with cover crop, NT-NC=no tillage with no cover crop,

$\mathrm{PG}=$ Perennial grass (fescue).

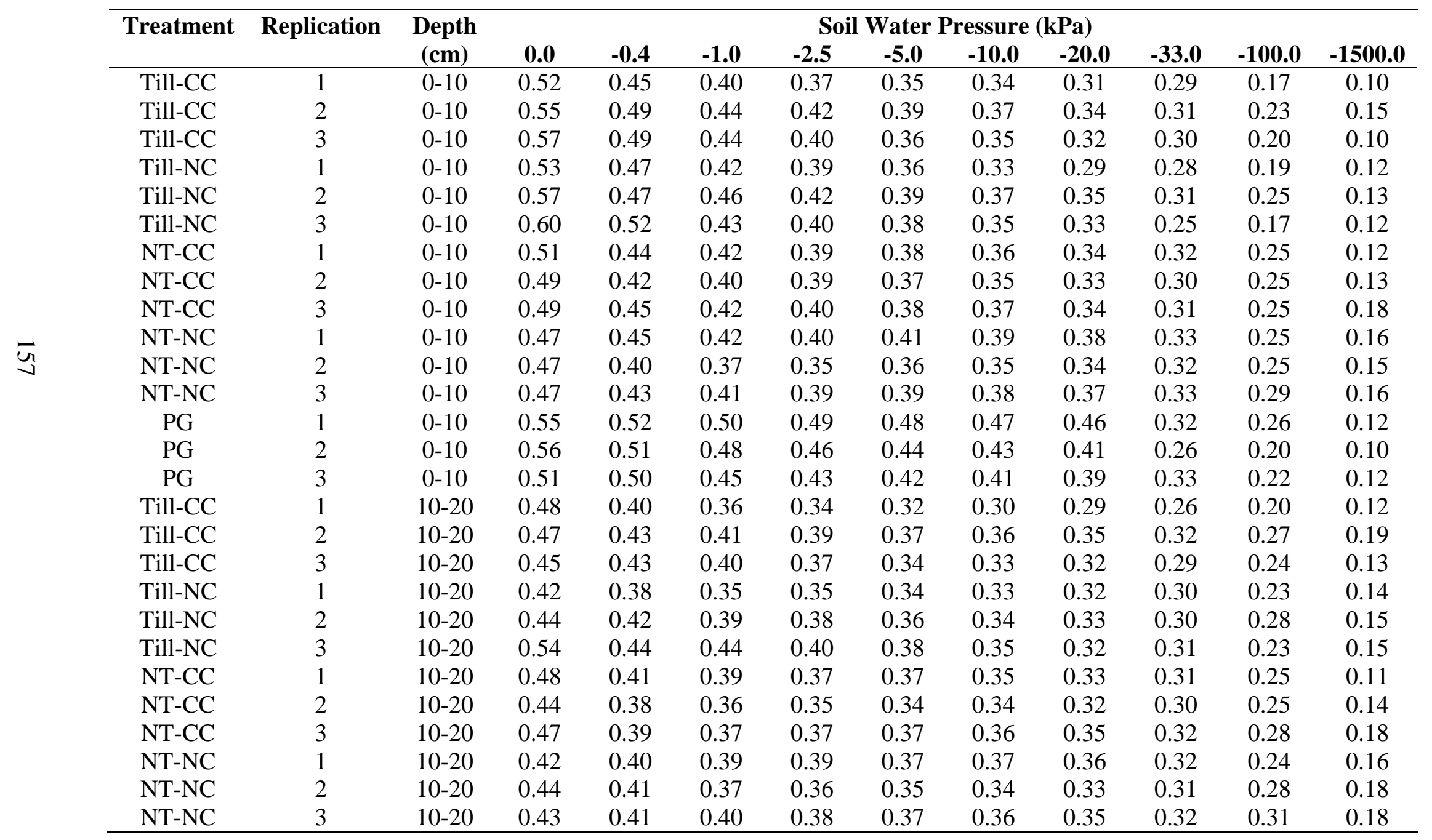


A 1.3. Cont'd

\begin{tabular}{|c|c|c|c|c|c|c|c|c|c|c|c|c|}
\hline \multirow[t]{2}{*}{ Treatment } & \multirow[t]{2}{*}{ Replication } & \multirow{2}{*}{$\begin{array}{c}\text { Depth } \\
\text { (cm) }\end{array}$} & \multicolumn{10}{|c|}{ Soil Water Pressure (kPa) } \\
\hline & & & 0.0 & -0.4 & -1.0 & -2.5 & -5.0 & -10.0 & -20.0 & -33.0 & -100.0 & -1500.0 \\
\hline $\mathrm{PG}$ & 1 & $10-20$ & 0.48 & 0.46 & 0.44 & 0.43 & 0.42 & 0.41 & 0.39 & 0.35 & 0.28 & 0.13 \\
\hline PG & 2 & $10-20$ & 0.45 & 0.44 & 0.40 & 0.37 & 0.37 & 0.35 & 0.34 & 0.32 & 0.27 & 0.13 \\
\hline Till-CC & 1 & $20-30$ & 0.47 & 0.38 & 0.32 & 0.29 & 0.32 & 0.31 & 0.24 & 0.27 & 0.22 & 0.08 \\
\hline Till-CC & 2 & $20-30$ & 0.46 & 0.41 & 0.39 & 0.38 & 0.37 & 0.37 & 0.36 & 0.32 & 0.27 & 0.20 \\
\hline Till-CC & 3 & $20-30$ & 0.46 & 0.41 & 0.40 & 0.37 & 0.33 & 0.32 & 0.33 & 0.28 & 0.22 & 0.14 \\
\hline Till-NC & 3 & $20-30$ & 0.45 & 0.42 & 0.39 & 0.38 & 0.37 & 0.33 & 0.32 & 0.32 & 0.25 & 0.16 \\
\hline NT-CC & 1 & $20-30$ & 0.46 & 0.41 & 0.38 & 0.38 & 0.37 & 0.36 & 0.34 & 0.31 & 0.29 & 0.13 \\
\hline NT-CC & 2 & $20-30$ & 0.45 & 0.39 & 0.38 & 0.36 & 0.34 & 0.33 & 0.32 & 0.28 & 0.28 & 0.13 \\
\hline NT-CC & 3 & $20-30$ & 0.47 & 0.42 & 0.40 & 0.40 & 0.38 & 0.38 & 0.38 & 0.33 & 0.31 & 0.23 \\
\hline NT-NC & 1 & $20-30$ & 0.43 & 0.42 & 0.40 & 0.39 & 0.38 & 0.37 & 0.36 & 0.32 & 0.28 & 0.17 \\
\hline PG & 3 & $20-30$ & 0.49 & 0.45 & 0.42 & 0.41 & 0.39 & 0.38 & 0.35 & 0.27 & 0.24 & 0.11 \\
\hline Till-CC & 1 & $30-40$ & 0.42 & 0.36 & 0.33 & 0.31 & 0.30 & 0.29 & 0.28 & 0.26 & 0.21 & 0.11 \\
\hline Till-CC & 2 & $30-40$ & 0.47 & 0.43 & 0.41 & 0.40 & 0.38 & 0.38 & 0.36 & 0.33 & 0.29 & 0.21 \\
\hline Till-CC & 3 & $30-40$ & 0.45 & 0.39 & 0.39 & 0.38 & 0.36 & 0.35 & 0.33 & 0.29 & 0.25 & 0.13 \\
\hline Till-NC & 1 & $30-40$ & 0.50 & 0.45 & 0.41 & 0.38 & 0.36 & 0.35 & 0.34 & 0.32 & 0.30 & 0.18 \\
\hline Till-NC & 2 & $30-40$ & 0.48 & 0.43 & 0.42 & 0.39 & 0.38 & 0.37 & 0.36 & 0.35 & 0.34 & 0.20 \\
\hline Till-NC & 3 & $30-40$ & 0.51 & 0.43 & 0.40 & 0.39 & 0.38 & 0.37 & 0.36 & 0.33 & 0.25 & 0.16 \\
\hline NT-CC & 1 & $30-40$ & 0.49 & 0.43 & 0.41 & 0.40 & 0.39 & 0.38 & 0.37 & 0.34 & 0.32 & 0.16 \\
\hline NT-CC & 2 & $30-40$ & 0.51 & 0.42 & 0.40 & 0.38 & 0.37 & 0.36 & 0.35 & 0.34 & 0.32 & 0.19 \\
\hline
\end{tabular}


A 1.3 Cont'd

\begin{tabular}{|c|c|c|c|c|c|c|c|c|c|c|c|c|}
\hline \multirow[t]{2}{*}{ Treatment } & \multirow[t]{2}{*}{ Replication } & \multirow{2}{*}{$\begin{array}{c}\text { Depth } \\
\text { (cm) }\end{array}$} & \multicolumn{10}{|c|}{ Soil Water Pressure (kPa) } \\
\hline & & & 0.0 & -0.4 & -1.0 & -2.5 & -5.0 & -10.0 & -20.0 & -33.0 & -100.0 & -1500.0 \\
\hline NT-CC & 3 & $30-40$ & 0.52 & 0.45 & 0.42 & 0.40 & 0.39 & 0.38 & 0.38 & 0.34 & 0.32 & 0.26 \\
\hline NT-NC & 1 & $30-40$ & 0.50 & 0.47 & 0.42 & 0.40 & 0.39 & 0.38 & 0.37 & 0.33 & 0.30 & 0.20 \\
\hline NT-NC & 2 & $30-40$ & 0.50 & 0.44 & 0.43 & 0.40 & 0.39 & 0.38 & 0.37 & 0.33 & 0.32 & 0.23 \\
\hline NT-NC & 3 & $30-40$ & 0.51 & 0.43 & 0.42 & 0.40 & 0.39 & 0.38 & 0.38 & 0.33 & 0.31 & 0.17 \\
\hline PG & 1 & $30-40$ & 0.50 & 0.45 & 0.44 & 0.43 & 0.41 & 0.40 & 0.38 & 0.32 & 0.29 & 0.11 \\
\hline PG & 2 & $30-40$ & 0.50 & 0.48 & 0.43 & 0.42 & 0.39 & 0.36 & 0.36 & 0.32 & 0.25 & 0.12 \\
\hline PG & 3 & $30-40$ & 0.47 & 0.44 & 0.41 & 0.40 & 0.39 & 0.37 & 0.33 & 0.31 & 0.28 & 0.09 \\
\hline
\end{tabular}


A 1.4. Volumetric water content $\left(\mathrm{cm}^{3} \mathrm{~cm}^{-3}\right)$ values for soil cores at $0,-0.4,-1.0,-2.5,-5.0,-10.0,-20.0,-33.0,-100.0$, and $1500.0 \mathrm{kPa}$ soil water pressure measured in 2014 before cover crop termination used in chapter 3. Till-CC=tillage with cover crop, Till-NC=tillage with no cover crop, NT-CC=no tillage with cover crop, NT-NC=no tillage with no cover crop.

\begin{tabular}{|c|c|c|c|c|c|c|c|c|c|c|c|c|}
\hline \multirow[t]{2}{*}{ Treatment } & \multirow[t]{2}{*}{ Replication } & \multirow{2}{*}{$\begin{array}{c}\text { Depth } \\
\text { (cm) }\end{array}$} & \multicolumn{10}{|c|}{ Soil Water Pressure (kPa) } \\
\hline & & & 0.0 & -0.4 & -1.0 & -2.5 & -5.0 & -10.0 & -20.0 & -33.0 & -100.0 & -1500.0 \\
\hline Till-CC & 1 & $0-10$ & 0.50 & 0.44 & 0.42 & 0.41 & 0.40 & 0.39 & 0.37 & 0.33 & 0.24 & 0.16 \\
\hline Till-CC & 2 & $0-10$ & 0.50 & 0.46 & 0.44 & 0.43 & 0.43 & 0.42 & 0.41 & 0.37 & 0.29 & 0.21 \\
\hline Till-CC & 3 & $0-10$ & 0.51 & 0.46 & 0.44 & 0.43 & 0.42 & 0.41 & 0.39 & 0.30 & 0.21 & 0.15 \\
\hline Till-NC & 1 & $0-10$ & 0.46 & 0.42 & 0.40 & 0.39 & 0.38 & 0.37 & 0.35 & 0.27 & 0.21 & 0.13 \\
\hline Till-NC & 2 & $0-10$ & 0.57 & 0.47 & 0.43 & 0.42 & 0.41 & 0.41 & 0.39 & 0.35 & 0.25 & 0.18 \\
\hline Till-NC & 3 & $0-10$ & 0.50 & 0.45 & 0.43 & 0.43 & 0.42 & 0.41 & 0.40 & 0.32 & 0.23 & 0.16 \\
\hline NT-CC & 1 & $0-10$ & 0.49 & 0.43 & 0.41 & 0.41 & 0.40 & 0.39 & 0.38 & 0.35 & 0.24 & 0.16 \\
\hline NT-CC & 2 & $0-10$ & 0.52 & 0.45 & 0.42 & 0.41 & 0.40 & 0.40 & 0.38 & 0.27 & 0.20 & 0.12 \\
\hline NT-CC & 3 & $0-10$ & 0.47 & 0.43 & 0.42 & 0.41 & 0.40 & 0.40 & 0.39 & 0.36 & 0.26 & 0.19 \\
\hline NT-NC & 1 & $0-10$ & 0.57 & 0.52 & 0.51 & 0.49 & 0.48 & 0.47 & 0.46 & 0.33 & 0.23 & 0.16 \\
\hline NT-NC & 2 & $0-10$ & 0.48 & 0.43 & 0.40 & 0.39 & 0.38 & 0.37 & 0.36 & 0.29 & 0.23 & 0.16 \\
\hline NT-NC & 3 & $0-10$ & 0.48 & 0.43 & 0.42 & 0.42 & 0.41 & 0.40 & 0.40 & 0.37 & 0.28 & 0.20 \\
\hline Till-CC & 1 & $10-20$ & 0.42 & 0.37 & 0.35 & 0.34 & 0.33 & 0.33 & 0.32 & 0.29 & 0.21 & 0.14 \\
\hline Till-CC & 2 & $10-20$ & 0.49 & 0.48 & 0.41 & 0.40 & 0.39 & 0.38 & 0.37 & 0.35 & 0.29 & 0.21 \\
\hline Till-CC & 3 & $10-20$ & 0.44 & 0.38 & 0.36 & 0.36 & 0.35 & 0.35 & 0.33 & 0.30 & 0.27 & 0.18 \\
\hline Till-NC & 1 & $10-20$ & 0.38 & 0.36 & 0.33 & 0.33 & 0.32 & 0.31 & 0.28 & 0.26 & 0.19 & 0.10 \\
\hline Till-NC & 2 & $10-20$ & 0.47 & 0.42 & 0.40 & 0.40 & 0.38 & 0.37 & 0.36 & 0.32 & 0.30 & 0.21 \\
\hline Till-NC & 3 & $10-20$ & 0.45 & 0.41 & 0.39 & 0.39 & 0.39 & 0.38 & 0.37 & 0.36 & 0.26 & 0.18 \\
\hline NT-CC & 1 & $10-20$ & 0.45 & 0.40 & 0.39 & 0.38 & 0.37 & 0.37 & 0.35 & 0.34 & 0.23 & 0.15 \\
\hline NT-CC & 2 & $10-20$ & 0.46 & 0.41 & 0.39 & 0.39 & 0.38 & 0.38 & 0.37 & 0.35 & 0.25 & 0.17 \\
\hline NT-CC & 3 & $10-20$ & 0.44 & 0.39 & 0.38 & 0.37 & 0.37 & 0.37 & 0.35 & 0.33 & 0.27 & 0.18 \\
\hline NT-NC & 1 & $10-20$ & 0.48 & 0.46 & 0.44 & 0.43 & 0.42 & 0.42 & 0.40 & 0.37 & 0.23 & 0.16 \\
\hline NT-NC & 2 & $10-20$ & 0.42 & 0.41 & 0.34 & 0.34 & 0.33 & 0.32 & 0.31 & 0.28 & 0.24 & 0.15 \\
\hline NT-NC & 3 & $10-20$ & 0.42 & 0.37 & 0.36 & 0.35 & 0.35 & 0.34 & 0.34 & 0.34 & 0.28 & 0.20 \\
\hline
\end{tabular}


A 1.5. Pore size distribution values for soil core samples measured in 2014 right after cover crop termination and spring tillage used in chapter 3 . Till-CC=tillage with cover crop, Till-NC=tillage with no cover crop, NT-CC=no tillage with cover crop, NT-NC=no tillage with no cover crop, $\mathrm{PG}=$ Perennial grass (fescue).

\begin{tabular}{|c|c|c|c|c|c|c|c|}
\hline Treatment & Replication & $\begin{array}{l}\text { Depth } \\
(\mathrm{cm}) \\
\end{array}$ & $\begin{array}{l}\text { Macropores } \\
(>1,000 \mu \mathrm{m})\end{array}$ & $\begin{array}{c}\text { Coarse } \\
\text { Mesopores } \\
(60-1,000 \mu \mathrm{m})\end{array}$ & $\begin{array}{c}\text { Fine } \\
\text { Mesopores } \\
(\mathbf{1 0}-\mathbf{6 0} \boldsymbol{\mu m}) \\
\end{array}$ & $\begin{array}{l}\text { Micropores } \\
(<10 \mu \mathrm{m}) \\
\end{array}$ & Total Pores \\
\hline Till-CC & 1 & $0-10$ & 0.068 & 0.104 & 0.052 & 0.293 & 0.517 \\
\hline Till-CC & 3 & $0-10$ & 0.078 & 0.138 & 0.055 & 0.301 & 0.572 \\
\hline Till-NC & 1 & $0-10$ & 0.058 & 0.109 & 0.074 & 0.284 & 0.525 \\
\hline Till-NC & 2 & $0-10$ & 0.097 & 0.083 & 0.077 & 0.313 & 0.570 \\
\hline NT-CC & 2 & $0-10$ & 0.071 & 0.055 & 0.065 & 0.301 & 0.492 \\
\hline NT-CC & 3 & $0-10$ & 0.044 & 0.066 & 0.077 & 0.307 & 0.494 \\
\hline NT-NC & 1 & $0-10$ & 0.017 & 0.044 & 0.075 & 0.331 & 0.468 \\
\hline NT-NC & 2 & $0-10$ & 0.067 & 0.041 & 0.043 & 0.317 & 0.467 \\
\hline NT-NC & 3 & $0-10$ & 0.039 & 0.041 & 0.062 & 0.327 & 0.469 \\
\hline PG & 1 & $0-10$ & 0.032 & 0.040 & 0.158 & 0.318 & 0.548 \\
\hline Till-CC & 3 & $10-20$ & 0.030 & 0.081 & 0.050 & 0.295 & 0.455 \\
\hline Till-NC & 1 & $10-20$ & 0.044 & 0.036 & 0.041 & 0.299 & 0.421 \\
\hline Till-NC & 2 & $10-20$ & 0.017 & 0.061 & 0.057 & 0.304 & 0.439 \\
\hline Till-NC & 3 & $10-20$ & 0.094 & 0.061 & 0.068 & 0.312 & 0.535 \\
\hline NT-CC & 1 & $10-20$ & 0.072 & 0.043 & 0.059 & 0.306 & 0.481 \\
\hline NT-CC & 2 & $10-20$ & 0.063 & 0.038 & 0.045 & 0.296 & 0.442 \\
\hline NT-CC & 3 & $10-20$ & 0.083 & 0.018 & 0.051 & 0.317 & 0.469 \\
\hline
\end{tabular}


A 1.5 Cont'd

\begin{tabular}{|c|c|c|c|c|c|c|c|}
\hline Treatment & Replication & $\begin{array}{l}\text { Depth } \\
(\mathrm{cm}) \\
\end{array}$ & $\begin{array}{l}\text { Macropores } \\
(>1,000 \mu \mathrm{m})\end{array}$ & $\begin{array}{c}\text { Coarse } \\
\text { Mesopores } \\
(60-1,000 \mu \mathrm{m}) \\
\end{array}$ & $\begin{array}{c}\text { Fine } \\
\text { Mesopores } \\
(\mathbf{1 0}-\mathbf{6 0} \boldsymbol{\mu m})\end{array}$ & $\begin{array}{l}\text { Micropores } \\
(<\mathbf{1 0} \mu \mathrm{m})\end{array}$ & Total Pores \\
\hline NT-NC & 1 & $10-20$ & 0.017 & 0.029 & 0.052 & 0.322 & 0.419 \\
\hline NT-NC & 3 & $10-20$ & 0.021 & 0.043 & 0.047 & 0.322 & 0.433 \\
\hline PG & 1 & $10-20$ & 0.014 & 0.043 & 0.064 & 0.354 & 0.475 \\
\hline PG & 2 & $10-20$ & 0.011 & 0.075 & 0.048 & 0.317 & 0.451 \\
\hline Till-CC & 2 & $20-30$ & 0.047 & 0.037 & 0.053 & 0.371 & 0.508 \\
\hline Till-CC & 3 & $20-30$ & 0.048 & 0.082 & 0.053 & 0.279 & 0.462 \\
\hline Till-NC & 1 & $20-30$ & 0.035 & 0.049 & 0.039 & 0.309 & 0.431 \\
\hline Till-NC & 2 & $20-30$ & 0.046 & 0.035 & 0.051 & 0.333 & 0.465 \\
\hline Till-NC & 3 & $20-30$ & 0.035 & 0.046 & 0.054 & 0.317 & 0.453 \\
\hline NT-CC & 1 & $20-30$ & 0.055 & 0.035 & 0.060 & 0.312 & 0.461 \\
\hline NT-NC & 3 & $20-30$ & 0.060 & 0.049 & 0.030 & 0.325 & 0.464 \\
\hline PG & 1 & $20-30$ & 0.026 & 0.029 & 0.090 & 0.312 & 0.457 \\
\hline PG & 2 & $20-30$ & 0.030 & 0.052 & 0.121 & 0.223 & 0.427 \\
\hline PG & 3 & $20-30$ & 0.042 & 0.058 & 0.117 & 0.273 & 0.489 \\
\hline Till-CC & 1 & $30-40$ & 0.063 & 0.055 & 0.041 & 0.261 & 0.420 \\
\hline Till-CC & 2 & $30-40$ & 0.038 & 0.046 & 0.052 & 0.332 & 0.467 \\
\hline Till-CC & 3 & $30-40$ & 0.051 & 0.037 & 0.063 & 0.295 & 0.445 \\
\hline Till-NC & 1 & $30-40$ & 0.049 & 0.086 & 0.044 & 0.317 & 0.497 \\
\hline Till-NC & 2 & $30-40$ & 0.052 & 0.055 & 0.028 & 0.349 & 0.484 \\
\hline Till-NC & 3 & $30-40$ & 0.085 & 0.043 & 0.057 & 0.326 & 0.511 \\
\hline
\end{tabular}


A 1.5 Cont'd

\begin{tabular}{cccccccc}
\hline Treatment & Replication & Depth & Macropores & $\begin{array}{c}\text { Coarse } \\
\text { Mesopores }\end{array}$ & $\begin{array}{c}\text { Fine } \\
\text { Mesopores } \\
(\mathbf{1 0}-\mathbf{6 0} \boldsymbol{\mu m})\end{array}$ & Micropores & Total Pores \\
$(<\mathbf{1 0} \boldsymbol{\mu m})$
\end{tabular}


A 1.6. Pore size distribution values for soil core samples measured in 2014 before cover crop termination used in chapter 3. Till-CC=tillage with cover crop, Till-NC=tillage with no cover crop, NT-CC=no tillage with cover crop.

\begin{tabular}{|c|c|c|c|c|c|c|c|}
\hline Treatment & Replication & $\begin{array}{l}\text { Depth } \\
(\mathrm{cm}) \\
\end{array}$ & $\begin{array}{l}\text { Macropores } \\
(>1,000 \mu \mathrm{m})\end{array}$ & $\begin{array}{c}\text { Coarse } \\
\text { Mesopores } \\
(\mathbf{6 0}-\mathbf{1 , 0 0 0} \boldsymbol{\mu m})\end{array}$ & $\begin{array}{c}\text { Fine } \\
\text { Mesopores } \\
(\mathbf{1 0}-\mathbf{6 0} \boldsymbol{\mu m})\end{array}$ & $\begin{array}{l}\text { Micropores } \\
(<\mathbf{1 0} \mu \mathrm{m})\end{array}$ & Total Pores \\
\hline Till-CC & 1 & $0-10$ & 0.059 & 0.046 & 0.068 & 0.328 & 0.501 \\
\hline Till-CC & 2 & $0-10$ & 0.039 & 0.029 & 0.055 & 0.373 & 0.495 \\
\hline Till-CC & 3 & $0-10$ & 0.055 & 0.035 & 0.116 & 0.305 & 0.510 \\
\hline Till-NC & 1 & $0-10$ & 0.041 & 0.040 & 0.107 & 0.272 & 0.460 \\
\hline Till-NC & 2 & $0-10$ & 0.094 & 0.058 & 0.061 & 0.354 & 0.566 \\
\hline Till-NC & 3 & $0-10$ & 0.053 & 0.029 & 0.103 & 0.315 & 0.500 \\
\hline NT-CC & 1 & $0-10$ & 0.067 & 0.023 & 0.056 & 0.347 & 0.494 \\
\hline NT-CC & 2 & $0-10$ & 0.077 & 0.046 & 0.133 & 0.269 & 0.525 \\
\hline NT-CC & 3 & $0-10$ & 0.042 & 0.029 & 0.037 & 0.365 & 0.473 \\
\hline NT-NC & 1 & $0-10$ & 0.044 & 0.037 & 0.153 & 0.331 & 0.565 \\
\hline NT-NC & 2 & $0-10$ & 0.050 & 0.046 & 0.090 & 0.294 & 0.480 \\
\hline NT-NC & 3 & $0-10$ & 0.043 & 0.026 & 0.032 & 0.375 & 0.476 \\
\hline Till-CC & 1 & $10-20$ & 0.046 & 0.037 & 0.046 & 0.289 & 0.418 \\
\hline Till-CC & 2 & $10-20$ & 0.010 & 0.092 & 0.040 & 0.349 & 0.491 \\
\hline Till-CC & 3 & $10-20$ & 0.059 & 0.035 & 0.046 & 0.304 & 0.443 \\
\hline Till-NC & 1 & $10-20$ & 0.017 & 0.040 & 0.060 & 0.260 & 0.378 \\
\hline Till-NC & 2 & $10-20$ & 0.052 & 0.046 & 0.053 & 0.323 & 0.474 \\
\hline Till-NC & 3 & $10-20$ & 0.043 & 0.026 & 0.027 & 0.359 & 0.455 \\
\hline NT-CC & 1 & $10-20$ & 0.058 & 0.023 & 0.034 & 0.340 & 0.455 \\
\hline NT-CC & 2 & $10-20$ & 0.052 & 0.026 & 0.036 & 0.348 & 0.461 \\
\hline NT-CC & 3 & $10-20$ & 0.040 & 0.023 & 0.041 & 0.331 & 0.435 \\
\hline NT-NC & 1 & $10-20$ & 0.015 & 0.037 & 0.053 & 0.371 & 0.476 \\
\hline NT-NC & 2 & $10-20$ & 0.012 & 0.081 & 0.044 & 0.282 & 0.419 \\
\hline NT-NC & 3 & $10-20$ & 0.051 & 0.020 & 0.012 & 0.336 & 0.419 \\
\hline
\end{tabular}




\section{Appendix 2}

A 2.1. van Genutchen parameter values calculated from water retention values right after cover crop termination and spring tillage used in chapter 4 . Till-CC=tillage with cover crop, Till-NC=tillage with no cover crop, NT-CC=no tillage with cover crop, NT-NC=no tillage with no cover crop, $\mathrm{PG}=$ Perennial grass (fescue).

\begin{tabular}{cccccc}
\hline Treatment & Replication & $\begin{array}{c}\text { Depth } \\
(\mathbf{c m})\end{array}$ & $\boldsymbol{\alpha}\left(\mathbf{m m}^{-\mathbf{1}}\right)$ & $\boldsymbol{n}$ & $\boldsymbol{r}^{\mathbf{2}}$ \\
\hline Till-CC & 1 & $0-10$ & 0.029 & 1.156 & 0.93 \\
Till-CC & 2 & $0-10$ & 0.021 & 1.139 & 0.97 \\
Till-CC & 3 & $0-10$ & 0.027 & 1.161 & 0.96 \\
Till-NC & 1 & $0-10$ & 0.021 & 1.155 & 0.97 \\
Till-NC & 2 & $0-10$ & 0.031 & 1.106 & 0.98 \\
Till-NC & 3 & $0-10$ & 0.040 & 1.254 & 0.93 \\
NT-CC & 1 & $0-10$ & 0.002 & 1.211 & 0.92 \\
NT-CC & 2 & $0-10$ & 0.004 & 1.162 & 0.94 \\
NT-CC & 3 & $0-10$ & 0.010 & 1.128 & 0.98 \\
NT-NC & 1 & $0-10$ & 0.002 & 1.191 & 0.94 \\
NT-NC & 2 & $0-10$ & 0.002 & 1.089 & 0.89 \\
NT-NC & 3 & $0-10$ & 0.002 & 1.156 & 0.91 \\
PG & 1 & $0-10$ & 0.001 & 1.683 & 0.94 \\
PG & 2 & $0-10$ & 0.001 & 1.446 & 0.91 \\
PG & 3 & $0-10$ & 0.001 & 1.300 & 0.95 \\
Till-CC & 1 & $10-20$ & 0.006 & 1.123 & 0.95 \\
Till-CC & 2 & $10-20$ & 0.006 & 1.116 & 0.96 \\
Till-CC & 3 & $10-20$ & 0.005 & 1.153 & 0.97 \\
Till-NC & 1 & $10-20$ & 0.001 & 1.249 & 0.94 \\
Till-NC & 2 & $10-20$ & 0.003 & 1.150 & 0.96 \\
Till-NC & 3 & $10-20$ & 0.002 & 1.132 & 0.97 \\
NT-CC & 1 & $10-20$ & 0.001 & 1.212 & 0.92 \\
NT-CC & 2 & $10-20$ & 0.001 & 1.178 & 0.92 \\
NT-CC & 3 & $10-20$ & 0.002 & 1.134 & 0.88 \\
NT-NC & 1 & $10-20$ & 0.001 & 1.115 & 0.98 \\
NT-NC & 2 & $10-20$ & 0.005 & 1.107 & 0.93 \\
NT-NC & 3 & $10-20$ & 0.003 & 1.123 & 0.92 \\
PG & 1 & $10-20$ & 0.001 & 1.284 & 0.98 \\
PG & $10-20$ & 0.001 & 1.191 & 0.94 \\
PG & 3 & $10-20$ & 0.001 & 1.215 & 0.90 \\
Till-CC & 1 & $20-30$ & 0.005 & 1.113 & 0.87 \\
Till-CC & 2 & $20-30$ & 0.001 & 1.156 & 0.95 \\
Till-CC & $20-30$ & 0.010 & 1.141 & 0.96 \\
\hline
\end{tabular}


A 2.1 Cont'd

\begin{tabular}{cccccc}
\hline Treatment & Replication & Depth $(\mathbf{c m})$ & $\boldsymbol{\alpha}\left(\mathbf{m m}^{-\mathbf{1}}\right)$ & $\boldsymbol{n}$ & $\boldsymbol{r}^{\mathbf{2}}$ \\
\hline Till-NC & 1 & $20-30$ & 0.001 & 1.186 & 0.95 \\
Till-NC & 2 & $20-30$ & 0.002 & 1.154 & 0.91 \\
Till-NC & 3 & $20-30$ & 0.004 & 1.141 & 0.97 \\
NT-CC & 1 & $20-30$ & 0.001 & 1.212 & 0.93 \\
NT-CC & 2 & $20-30$ & 0.004 & 1.137 & 0.92 \\
NT-CC & 3 & $20-30$ & 0.006 & 1.086 & 0.93 \\
NT-NC & 1 & $20-30$ & 0.002 & 1.152 & 0.94 \\
NT-NC & 2 & $20-30$ & 0.001 & 1.176 & 0.91 \\
NT-NC & 3 & $20-30$ & 0.002 & 1.137 & 0.91 \\
PG & 1 & $20-30$ & 0.001 & 1.282 & 0.96 \\
PG & 2 & $20-30$ & 0.002 & 1.206 & 0.94 \\
PG & 3 & $20-30$ & 0.002 & 1.229 & 0.96 \\
Till-CC & 1 & $30-40$ & 0.002 & 1.111 & 0.92 \\
Till-CC & 2 & $30-40$ & 0.003 & 1.114 & 0.96 \\
Till-CC & 3 & $30-40$ & 0.001 & 1.205 & 0.96 \\
Till-NC & 1 & $30-40$ & 0.003 & 1.101 & 0.92 \\
Till-NC & 2 & $30-40$ & 0.001 & 1.229 & 0.87 \\
Till-NC & 3 & $30-40$ & 0.005 & 1.137 & 0.91 \\
NT-CC & 1 & $30-40$ & 0.001 & 1.166 & 0.91 \\
NT-CC & 2 & $30-40$ & 0.010 & 1.072 & 0.92 \\
NT-CC & 3 & $30-40$ & 0.005 & 1.062 & 0.98 \\
NT-NC & 1 & $30-40$ & 0.009 & 1.094 & 0.95 \\
NT-NC & 2 & $30-40$ & 0.018 & 1.069 & 0.96 \\
NT-NC & 3 & $30-40$ & 0.001 & 1.172 & 0.93 \\
PG & 1 & $30-40$ & 0.001 & 1.268 & 0.96 \\
PG & 2 & $30-40$ & 0.002 & 1.201 & 0.96 \\
PG & 3 & $30-40$ & 0.001 & 1.257 & 0.95 \\
\hline
\end{tabular}


A 2.2. van Genutchen parameter values calculated from water retention values before cover crop termination. Till-CC=tillage with cover crop, Till-NC=tillage with no cover crop, NT-CC $=$ no tillage with cover crop, NT-NC=no tillage with no cover crop.

\begin{tabular}{cccccc}
\hline Treatment & Replication & Depth $(\mathbf{c m})$ & $\left.\boldsymbol{\alpha} \mathbf{( m m}^{-1}\right)$ & $\boldsymbol{n}$ & $\boldsymbol{r}^{\mathbf{2}}$ \\
\hline Till-CC & 1 & $0-10$ & 0.001 & 1.197 & 0.93 \\
Till-CC & 2 & $0-10$ & 0.001 & 1.600 & 0.95 \\
Till-CC & 3 & $0-10$ & 0.001 & 1.935 & 0.94 \\
Till-NC & 1 & $0-10$ & 0.001 & 1.480 & 0.94 \\
Till-NC & 2 & $0-10$ & 0.006 & 1.100 & 0.89 \\
Till-NC & 3 & $0-10$ & 0.001 & 1.909 & 0.94 \\
NT-CC & 1 & $0-10$ & 0.001 & 1.747 & 0.93 \\
NT-CC & 2 & $0-10$ & 0.001 & 1.673 & 0.90 \\
NT-CC & 3 & $0-10$ & 0.001 & 1.794 & 0.94 \\
NT-NC & 1 & $0-10$ & 0.001 & 1.499 & 0.94 \\
NT-NC & 2 & $0-10$ & 0.001 & 1.176 & 0.92 \\
NT-NC & 3 & $0-10$ & 0.001 & 1.822 & 0.95 \\
Till-CC & 1 & $10-20$ & 0.001 & 1.207 & 0.92 \\
Till-CC & 2 & $10-20$ & 0.004 & 1.092 & 0.93 \\
Till-CC & 3 & $10-20$ & 0.008 & 1.098 & 0.91 \\
Till-NC & 1 & $10-20$ & 0.001 & 1.253 & 0.97 \\
Till-NC & 2 & $10-20$ & 0.001 & 1.082 & 0.95 \\
Till-NC & 3 & $10-20$ & 0.001 & 1.787 & 0.94 \\
NT-CC & 1 & $10-20$ & 0.001 & 1.600 & 0.93 \\
NT-CC & 2 & $10-20$ & 0.001 & 1.723 & 0.93 \\
NT-CC & 3 & $10-20$ & 0.001 & 1.166 & 0.95 \\
NT-NC & 1 & $10-20$ & 0.001 & 1.122 & 0.97 \\
NT-NC & 2 & $10-20$ & 0.006 & 1.112 & 0.93 \\
NT-NC & 3 & $10-20$ & 0.003 & 1.131 & 0.89 \\
\hline
\end{tabular}


A 2.3. Cumulative infiltration in cover crop with tillage (CC-Till) management measured in 2014.

\begin{tabular}{cccc}
\hline & \multicolumn{3}{c}{ Replications } \\
\cline { 2 - 4 } Time (Minutes) & I (mm) & III $(\mathbf{m m})$ \\
\hline 0 & 0.00 & 0.00 & 0.00 \\
2 & 3.25 & 28.12 & 28.12 \\
4 & 3.25 & 33.92 & 33.92 \\
6 & 3.25 & 38.07 & 38.07 \\
8 & 3.25 & 40.56 & 40.56 \\
10 & 4.91 & 46.69 & 46.69 \\
15 & 4.91 & 52.99 & 52.99 \\
20 & 6.57 & 62.94 & 62.94 \\
25 & 8.22 & 69.90 & 69.90 \\
30 & 9.88 & 76.20 & 76.20 \\
35 & 11.54 & 81.18 & 81.18 \\
40 & 14.03 & 87.65 & 87.65 \\
45 & 14.86 & 94.77 & 94.77 \\
50 & 16.51 & 99.09 & 99.09 \\
60 & 18.17 & 111.02 & 111.02 \\
90 & 28.12 & 140.87 & 140.87 \\
120 & 36.41 & 167.40 & 167.40 \\
150 & 48.02 & - & - \\
180 & 57.97 & - & - \\
\hline
\end{tabular}


A 2.4. Cumulative infiltration in cover crop with no tillage (CC-NT) management measured in 2014.

\begin{tabular}{cccc}
\hline & & Replications \\
\cline { 2 - 4 } Time (Minutes) & I (mm) & II (mm) & II (mm) \\
\hline 0 & 0.00 & 0.00 & 0.00 \\
2 & 0.90 & 18.17 & 0.90 \\
4 & 2.56 & 21.49 & 2.56 \\
6 & 4.22 & 24.80 & 4.22 \\
8 & 6.71 & 29.78 & 6.71 \\
10 & 10.02 & 29.78 & 10.02 \\
15 & 12.51 & 36.41 & 12.51 \\
20 & 16.66 & 43.04 & 16.66 \\
25 & 21.63 & 48.85 & 21.63 \\
30 & 26.60 & 51.33 & 26.60 \\
35 & 29.92 & 63.77 & 29.92 \\
40 & 34.89 & 77.86 & 34.89 \\
45 & 38.21 & 87.81 & 38.21 \\
50 & 41.53 & 97.76 & 41.53 \\
60 & 48.16 & 117.66 & 48.16 \\
90 & 65.57 & 177.35 & 65.57 \\
120 & 79.66 & 193.93 & 79.66 \\
150 & - & 231.23 & - \\
180 & - & 249.47 & - \\
\hline
\end{tabular}


A 2.5. Cumulative infiltration in no cover crop with tillage (NC-Till) management measured in 2014.

\begin{tabular}{cccc}
\hline & \multicolumn{3}{c}{ Replications } \\
\cline { 2 - 4 } Time (Minutes) & I (mm) & II (mm) & II (mm) \\
\hline 0 & 0.00 & 0.00 & 0.00 \\
2 & 1.05 & 1.05 & 4.69 \\
4 & 1.05 & 1.05 & 8.01 \\
6 & 7.68 & 7.68 & 8.01 \\
8 & 7.68 & 7.68 & 11.33 \\
10 & 7.68 & 7.68 & 15.47 \\
15 & 10.99 & 10.99 & 19.78 \\
20 & 11.82 & 11.82 & 20.44 \\
25 & 14.31 & 14.31 & 26.25 \\
30 & 14.31 & 14.31 & 26.25 \\
35 & 17.63 & 17.63 & 32.88 \\
40 & 18.46 & 18.46 & 32.88 \\
45 & 18.79 & 18.79 & 32.88 \\
50 & 19.28 & 19.28 & 32.88 \\
60 & 23.43 & 23.43 & 37.03 \\
90 & 28.40 & 28.40 & 47.80 \\
120 & 33.38 & 33.38 & 57.75 \\
\hline
\end{tabular}


A 2.6. Cumulative infiltration in no cover crop with no tillage (NC-NT) management measured in 2014.

\begin{tabular}{cccc}
\hline & \multicolumn{3}{c}{ Replications } \\
\cline { 2 - 4 } Time (Minutes) & I $(\mathbf{m m})$ & II $(\mathbf{m m})$ & III $(\mathbf{m m})$ \\
\hline 0 & 0.00 & 0.00 & 0.00 \\
2 & 0.74 & 0.74 & 0.74 \\
4 & 2.73 & 2.73 & 2.73 \\
6 & 2.73 & 2.73 & 2.73 \\
8 & 5.38 & 5.38 & 5.38 \\
10 & 5.38 & 5.38 & 5.38 \\
15 & 8.70 & 8.70 & 8.70 \\
20 & 11.52 & 11.52 & 11.52 \\
25 & 11.68 & 11.68 & 11.68 \\
30 & 14.50 & 14.50 & 14.50 \\
35 & 14.50 & 14.50 & 14.50 \\
40 & 17.49 & 17.49 & 17.49 \\
45 & 17.49 & 17.49 & 17.49 \\
50 & 17.49 & 17.49 & 17.49 \\
60 & 19.97 & 19.97 & 19.97 \\
90 & 27.43 & 27.43 & 27.43 \\
120 & 34.07 & 34.07 & 34.07 \\
\hline
\end{tabular}


A 2.7. Cumulative infiltration in perennial grass (PG) measured in 2014 .

\begin{tabular}{cccc}
\hline & \multicolumn{3}{c}{ Replications } \\
\cline { 2 - 4 } Time (Minutes) & I (mm) & II $(\mathbf{m m})$ & III (mm) \\
\hline 0 & 0.00 & 0.00 & 0.00 \\
2 & 0.74 & 8.22 & 8.22 \\
4 & 15.66 & 9.88 & 9.88 \\
6 & 30.58 & 11.54 & 11.54 \\
8 & 42.19 & 13.20 & 13.20 \\
10 & 52.14 & 13.20 & 13.20 \\
15 & 70.38 & 16.51 & 16.51 \\
20 & 86.96 & 18.17 & 18.17 \\
25 & 115.14 & 19.00 & 19.00 \\
30 & 135.04 & 19.83 & 19.83 \\
35 & 146.65 & 19.83 & 19.83 \\
40 & 151.62 & 21.49 & 21.49 \\
45 & 168.20 & 24.80 & 24.80 \\
50 & 201.36 & 24.80 & 24.80 \\
60 & 222.92 & 36.41 & 36.41 \\
90 & 261.05 & 64.60 & 64.60 \\
120 & 290.90 & 77.86 & 77.86 \\
\hline
\end{tabular}


A 2.8. Cumulative infiltration in cover crop with tillage (CC-Till) management measured in 2015 .

\begin{tabular}{cccc}
\hline & \multicolumn{3}{c}{ Replications } \\
\cline { 2 - 4 } Time (Minutes) & $\mathbf{I}(\mathbf{m m})$ & $\mathbf{I} \mathbf{( m m})$ & $\mathbf{I I I}(\mathbf{m m})$ \\
\hline 0 & 0.00 & 23.43 & 0.00 \\
2 & 15.14 & 23.43 & 23.43 \\
4 & 21.77 & 26.75 & 26.43 \\
6 & 23.43 & 26.75 & 26.75 \\
8 & 23.43 & 26.75 & 26.75 \\
10 & 23.43 & 28.40 & 28.40 \\
15 & 23.43 & 31.72 & 31.72 \\
20 & 25.92 & 32.88 & 32.88 \\
25 & 25.92 & 35.04 & 35.04 \\
30 & 30.06 & 38.35 & 38.35 \\
35 & 31.72 & 39.18 & 39.18 \\
40 & 31.72 & 41.67 & 41.67 \\
45 & 33.38 & 45.81 & 45.81 \\
50 & 33.38 & 54.10 & 54.10 \\
60 & 38.35 & 86.44 & 86.44 \\
90 & 48.30 & 118.77 & 118.77 \\
120 & 69.86 & & \\
\hline
\end{tabular}


A 2.9. Cumulative infiltration in cover crop with no tillage (CC-NT) management measured in 2015.

\begin{tabular}{cccc}
\hline & \multicolumn{3}{c}{ Replications } \\
\cline { 2 - 4 } Time (Minutes) & I (mm) & II $(\mathbf{m m})$ & II $(\mathbf{m m})$ \\
\hline 0 & 0.00 & 0.00 & 0.00 \\
2 & 2.49 & 0.83 & 2.49 \\
4 & 5.81 & 10.78 & 5.81 \\
6 & 8.29 & 24.05 & 8.29 \\
8 & 12.44 & 29.02 & 12.44 \\
10 & 15.76 & 30.68 & 15.76 \\
15 & 19.07 & 33.99 & 19.07 \\
20 & 20.73 & 37.31 & 20.73 \\
25 & 25.70 & 43.94 & 25.70 \\
30 & 30.68 & 47.26 & 30.68 \\
35 & 33.99 & 57.21 & 33.99 \\
40 & 38.97 & 65.50 & 38.97 \\
45 & 43.94 & 70.47 & 43.94 \\
50 & 47.26 & 72.13 & 47.26 \\
60 & 55.55 & 77.10 & 55.55 \\
90 & 68.81 & 108.61 & 68.81 \\
120 & 87.05 & 130.16 & 87.05 \\
\hline
\end{tabular}


A 2.10. Cumulative infiltration in no cover crop with tillage (NC-Till) management measured in 2015.

\begin{tabular}{cccc}
\hline & \multicolumn{3}{c}{ Replications } \\
\cline { 2 - 4 } Time (Minutes) & I (mm) & II (mm) & III $(\mathbf{m m})$ \\
\hline 0 & 0.00 & 0.00 & 0.00 \\
2 & 1.87 & 1.87 & 0.22 \\
4 & 3.53 & 3.53 & 1.87 \\
6 & 5.19 & 5.19 & 1.87 \\
8 & 6.85 & 6.85 & 3.53 \\
10 & 7.68 & 7.68 & 3.53 \\
15 & 10.17 & 10.17 & 5.19 \\
20 & 13.48 & 13.48 & 7.68 \\
25 & 16.80 & 16.80 & 8.51 \\
30 & 21.77 & 21.77 & 9.34 \\
35 & 25.09 & 25.09 & 10.99 \\
40 & 28.40 & 28.40 & 10.99 \\
45 & 33.38 & 33.38 & 12.65 \\
50 & 36.69 & 36.69 & 15.14 \\
60 & 43.33 & 43.33 & 15.14 \\
90 & 66.54 & 66.54 & 22.60 \\
120 & 86.44 & 86.44 & 25.92 \\
\hline
\end{tabular}


A 2.11. Cumulative infiltration in no cover crop with no tillage (NC-NT) management measured in 2015.

\begin{tabular}{cccc}
\hline & \multicolumn{3}{c}{ Replications } \\
\cline { 2 - 4 } Time (Minutes) & I $(\mathbf{m m})$ & II $(\mathbf{m m})$ & III $(\mathbf{m m})$ \\
\hline 0 & 0.00 & 0.00 & 0.00 \\
2 & 3.63 & 3.63 & 0.74 \\
4 & 5.29 & 5.29 & 2.73 \\
6 & 5.29 & 5.29 & 2.73 \\
8 & 5.29 & 5.29 & 5.38 \\
10 & 6.95 & 6.95 & 5.38 \\
15 & 8.60 & 8.60 & 8.70 \\
20 & 11.92 & 11.92 & 11.52 \\
25 & 15.24 & 15.24 & 11.68 \\
30 & 16.89 & 16.89 & 14.50 \\
35 & 20.21 & 20.21 & 14.50 \\
40 & 23.53 & 23.53 & 17.49 \\
45 & 25.18 & 25.18 & 17.49 \\
50 & 28.50 & 28.50 & 17.49 \\
60 & 33.47 & 33.47 & 19.97 \\
90 & 51.71 & 51.71 & 27.43 \\
120 & 71.61 & 71.61 & 34.07 \\
\hline
\end{tabular}


A 2.12. Cumulative infiltration in perennial grass (PG) measured in 2015 .

\begin{tabular}{cccc}
\hline & \multicolumn{3}{c}{ Replications } \\
\cline { 2 - 4 } Time (Minutes) & I (mm) & II $(\mathbf{m m})$ & III $(\mathbf{m m})$ \\
\hline 0 & 0.00 & 0.00 & 0.00 \\
2 & 10.17 & 3.25 & 10.17 \\
4 & 10.17 & 4.91 & 10.17 \\
6 & 10.17 & 4.91 & 10.17 \\
8 & 10.17 & 4.91 & 10.17 \\
10 & 10.17 & 6.57 & 10.17 \\
15 & 16.80 & 6.57 & 16.80 \\
20 & 17.63 & 6.57 & 17.63 \\
25 & 18.46 & 8.22 & 18.46 \\
30 & 23.43 & 8.22 & 23.43 \\
35 & 25.09 & 11.54 & 25.09 \\
40 & 25.09 & 11.54 & 25.09 \\
45 & 28.40 & 11.54 & 28.40 \\
50 & 31.72 & 11.54 & 31.72 \\
60 & 35.04 & 11.54 & 35.04 \\
90 & 41.67 & 14.86 & 41.67 \\
120 & 51.62 & 19.83 & 51.62 \\
\hline
\end{tabular}


A 2.13. Field saturated hydraulic conductivity $\left(K_{f s}, 2014\right.$ data) versus laboratory measured saturated hydraulic conductivity $\left(K_{\text {sat }}, 2014\right.$ data).

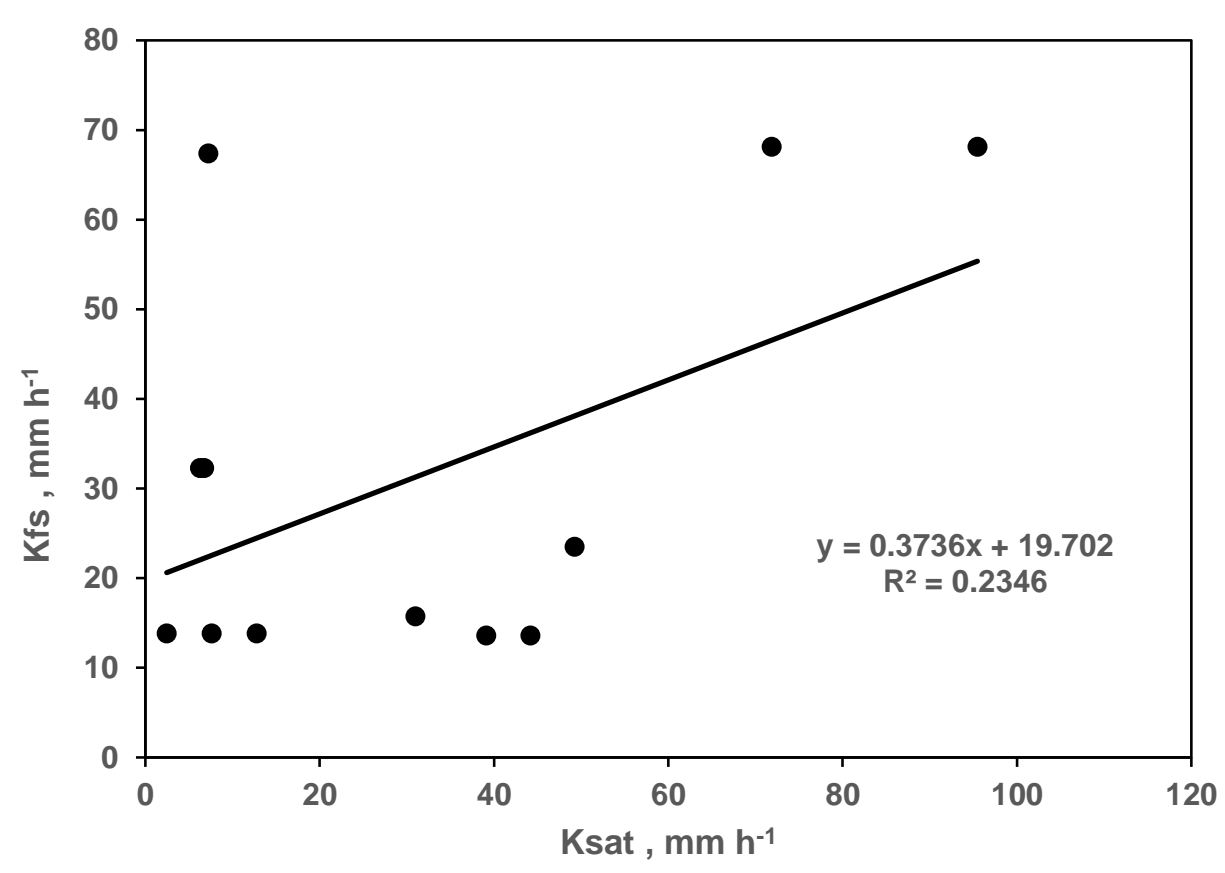




\section{Appendix 3}

A 3.1. Soil organic carbon (SOC) and bulk density (Db) measured in 2015 and used in chapter 5. $\mathrm{CC}=$ cover crops, $\mathrm{NC}=$ no cover crop, $\mathrm{GM}=$ giant miscanthus, and $\mathrm{SG}=$ switchgrass.

\begin{tabular}{|c|c|c|c|c|}
\hline Treatment & Replicate & Depth (cm) & SOC $\left(\mathrm{g} \mathrm{kg}^{-1}\right)$ & Db $\left(\mathrm{g} \mathrm{cm}^{-3}\right)$ \\
\hline $\mathrm{CC}$ & 1 & $0-10$ & 19.80 & 1.21 \\
\hline $\mathrm{NC}$ & 1 & $0-10$ & 17.20 & 1.29 \\
\hline $\mathrm{CC}$ & 2 & $0-10$ & 19.60 & 1.23 \\
\hline $\mathrm{NC}$ & 2 & $0-10$ & 16.90 & 1.29 \\
\hline $\mathrm{CC}$ & 3 & $0-10$ & 19.20 & 1.22 \\
\hline $\mathrm{NC}$ & 3 & $0-10$ & 17.50 & 1.29 \\
\hline GM & 1 & $0-10$ & 23.60 & 0.99 \\
\hline GM & 2 & $0-10$ & 24.70 & 1.00 \\
\hline GM & 3 & $0-10$ & 24.10 & 1.00 \\
\hline SG & 1 & $0-10$ & 22.60 & 1.01 \\
\hline SG & 2 & $0-10$ & 23.40 & 0.99 \\
\hline SG & 3 & $0-10$ & 23.20 & 1.15 \\
\hline $\mathrm{CC}$ & 1 & $10-20$ & 17.30 & 1.44 \\
\hline $\mathrm{NC}$ & 1 & $10-20$ & 12.30 & 1.47 \\
\hline $\mathrm{CC}$ & 2 & $10-20$ & 17.70 & 1.44 \\
\hline $\mathrm{NC}$ & 2 & $10-20$ & 12.00 & 1.46 \\
\hline $\mathrm{CC}$ & 3 & $10-20$ & 16.90 & 1.44 \\
\hline $\mathrm{NC}$ & 3 & $10-20$ & 12.20 & 1.48 \\
\hline GM & 1 & $10-20$ & 21.80 & 1.43 \\
\hline GM & 2 & $10-20$ & 21.20 & 1.44 \\
\hline GM & 3 & $10-20$ & 22.10 & 1.43 \\
\hline $\mathrm{SG}$ & 1 & $10-20$ & 21.30 & 1.41 \\
\hline $\mathrm{SG}$ & 2 & $10-20$ & 22.00 & 1.45 \\
\hline SG & 3 & $10-20$ & 21.50 & 1.43 \\
\hline $\mathrm{CC}$ & 1 & $20-30$ & 14.80 & 1.41 \\
\hline $\mathrm{NC}$ & 1 & $20-30$ & 9.10 & 1.45 \\
\hline $\mathrm{CC}$ & 2 & $20-30$ & 15.30 & 1.42 \\
\hline $\mathrm{NC}$ & 2 & $20-30$ & 8.00 & 1.41 \\
\hline $\mathrm{CC}$ & 3 & $20-30$ & 14.20 & 1.40 \\
\hline $\mathrm{NC}$ & 3 & $20-30$ & 8.80 & 1.48 \\
\hline GM & 1 & $20-30$ & 17.70 & 1.28 \\
\hline GM & 2 & $20-30$ & 18.70 & 1.41 \\
\hline GM & 3 & $20-30$ & 18.40 & 1.45 \\
\hline SG & 1 & $20-30$ & 17.40 & 1.40 \\
\hline $\mathrm{SG}$ & 2 & $20-30$ & 18.10 & 1.34 \\
\hline $\mathrm{SG}$ & 3 & $20-30$ & 17.30 & 1.42 \\
\hline
\end{tabular}


A 3.2. Thermal conductivity $(\lambda)$, volumetric heat capacity $\left(C_{V}\right)$, thermal diffusivity $(D)$, and volumetric water content $(\theta)$ at saturation measured in 2015 and used in chapter 5. $\mathrm{CC}=$ cover crops, $\mathrm{NC}=$ no cover crop, $\mathrm{GM}=$ giant miscanthus, and $\mathrm{SG}=$ switchgrass.

\begin{tabular}{|c|c|c|c|c|c|c|}
\hline Treatment & Rep & $\begin{array}{c}\text { Depth } \\
(\mathrm{cm})\end{array}$ & $\begin{array}{c}\lambda \\
\left(\mathbf{W} \mathbf{m}^{-1} K^{-1}\right)\end{array}$ & $\begin{array}{c}C_{V} \\
\left(\mathbf{M J ~ m}^{-3} \mathrm{~K}^{-1}\right)\end{array}$ & $\begin{array}{c}D \\
\left(\mathrm{~mm}^{2} \mathrm{~s}^{-1}\right)\end{array}$ & $\begin{array}{c}\theta \\
\left(\mathrm{cm}^{3} \mathrm{~cm}^{-3}\right) \\
\end{array}$ \\
\hline $\mathrm{CC}$ & 1 & $0-10$ & 1.38 & 3.68 & 0.37 & 0.50 \\
\hline $\mathrm{NC}$ & 1 & $0-10$ & 1.39 & 3.11 & 0.45 & 0.38 \\
\hline $\mathrm{CC}$ & 2 & $0-10$ & 1.35 & 3.66 & 0.37 & 0.51 \\
\hline $\mathrm{NC}$ & 2 & $0-10$ & 1.37 & 3.12 & 0.44 & 0.36 \\
\hline $\mathrm{CC}$ & 3 & $0-10$ & 1.33 & 3.64 & 0.37 & 0.53 \\
\hline $\mathrm{NC}$ & 3 & $0-10$ & 1.36 & 3.11 & 0.44 & 0.38 \\
\hline GM & 1 & $0-10$ & 1.22 & 3.84 & 0.32 & 0.60 \\
\hline GM & 2 & $0-10$ & 1.13 & 3.83 & 0.29 & 0.64 \\
\hline GM & 3 & $0-10$ & 1.20 & 3.84 & 0.31 & 0.62 \\
\hline SG & 1 & $0-10$ & 1.26 & 3.74 & 0.34 & 0.64 \\
\hline $\mathrm{SG}$ & 2 & $0-10$ & 1.29 & 3.74 & 0.35 & 0.64 \\
\hline $\mathrm{SG}$ & 3 & $0-10$ & 1.35 & 3.74 & 0.36 & 0.59 \\
\hline $\mathrm{CC}$ & 1 & $10-20$ & 1.36 & 3.64 & 0.37 & 0.41 \\
\hline $\mathrm{NC}$ & 1 & $10-20$ & 1.42 & 3.11 & 0.46 & 0.38 \\
\hline $\mathrm{CC}$ & 2 & $10-20$ & 1.37 & 3.65 & 0.37 & 0.41 \\
\hline $\mathrm{NC}$ & 2 & $10-20$ & 1.34 & 3.11 & 0.43 & 0.37 \\
\hline $\mathrm{CC}$ & 3 & $10-20$ & 1.36 & 3.59 & 0.38 & 0.42 \\
\hline $\mathrm{NC}$ & 3 & $10-20$ & 1.38 & 3.11 & 0.44 & 0.29 \\
\hline GM & 1 & $10-20$ & 1.23 & 3.82 & 0.32 & 0.51 \\
\hline GM & 2 & $10-20$ & 1.13 & 3.67 & 0.31 & 0.49 \\
\hline GM & 3 & $10-20$ & 1.22 & 3.90 & 0.31 & 0.50 \\
\hline $\mathrm{SG}$ & 1 & $10-20$ & 1.26 & 3.73 & 0.34 & 0.51 \\
\hline $\mathrm{SG}$ & 2 & $10-20$ & 1.32 & 3.70 & 0.36 & 0.48 \\
\hline $\mathrm{SG}$ & 3 & $10-20$ & 1.35 & 3.80 & 0.36 & 0.48 \\
\hline $\mathrm{CC}$ & 1 & $20-30$ & 1.24 & 3.20 & 0.39 & 0.41 \\
\hline $\mathrm{NC}$ & 1 & $20-30$ & 1.38 & 3.11 & 0.44 & 0.37 \\
\hline $\mathrm{CC}$ & 2 & $20-30$ & 1.31 & 3.42 & 0.38 & 0.45 \\
\hline $\mathrm{NC}$ & 2 & $20-30$ & 1.35 & 3.11 & 0.43 & 0.37 \\
\hline $\mathrm{CC}$ & 3 & $20-30$ & 1.32 & 3.58 & 0.37 & 0.42 \\
\hline $\mathrm{NC}$ & 3 & $20-30$ & 1.34 & 3.11 & 0.43 & 0.39 \\
\hline GM & 1 & $20-30$ & 1.09 & 3.69 & 0.30 & 0.50 \\
\hline GM & 2 & $20-30$ & 1.11 & 3.67 & 0.30 & 0.50 \\
\hline GM & 3 & $20-30$ & 1.18 & 3.87 & 0.31 & 0.46 \\
\hline $\mathrm{SG}$ & 1 & $20-30$ & 1.17 & 3.67 & 0.32 & 0.49 \\
\hline SG & 2 & $20-30$ & 1.26 & 3.71 & 0.34 & 0.51 \\
\hline $\mathrm{SG}$ & 3 & $20-30$ & 1.26 & 3.73 & 0.34 & 0.49 \\
\hline
\end{tabular}


A 3.3. Thermal conductivity $(\lambda)$, volumetric heat capacity $\left(C_{V}\right)$, thermal diffusivity $(D)$, and volumetric water content $(\theta)$ at $-33 \mathrm{kPa}$ pressure measured in 2015 and used in chapter 5 . $\mathrm{CC}=$ cover crops, $\mathrm{NC}=$ no cover crop, $\mathrm{GM}=$ giant miscanthus, and $\mathrm{SG}=$ switchgrass.

\begin{tabular}{|c|c|c|c|c|c|c|}
\hline Treatment & Rep & $\begin{array}{c}\text { Depth } \\
\text { (cm) }\end{array}$ & $\begin{array}{c}\lambda \\
\left(W^{-1} K^{-1}\right)\end{array}$ & $\begin{array}{c}C_{V} \\
\left(\mathbf{M J} \mathbf{~ m}^{-3} \mathbf{K}^{-1}\right)\end{array}$ & $\begin{array}{c}D \\
\left(\mathrm{~mm}^{2} \mathrm{~s}^{-1}\right)\end{array}$ & $\begin{array}{c}\theta \\
\left(\mathrm{cm}^{3} \mathrm{~cm}^{-3}\right)\end{array}$ \\
\hline $\mathrm{CC}$ & 1 & $0-10$ & 1.18 & 3.07 & 0.39 & 0.38 \\
\hline $\mathrm{NC}$ & 1 & $0-10$ & 1.19 & 2.57 & 0.46 & 0.28 \\
\hline $\mathrm{CC}$ & 2 & $0-10$ & 1.26 & 3.08 & 0.41 & 0.39 \\
\hline $\mathrm{NC}$ & 2 & $0-10$ & 1.23 & 2.57 & 0.48 & 0.32 \\
\hline $\mathrm{CC}$ & 3 & $0-10$ & 1.21 & 3.15 & 0.38 & 0.39 \\
\hline $\mathrm{NC}$ & 3 & $0-10$ & 1.20 & 2.58 & 0.46 & 0.31 \\
\hline GM & 1 & $0-10$ & 1.04 & 3.09 & 0.33 & 0.39 \\
\hline GM & 2 & $0-10$ & 1.10 & 3.15 & 0.35 & 0.44 \\
\hline GM & 3 & $0-10$ & 1.14 & 3.09 & 0.37 & 0.45 \\
\hline $\mathrm{SG}$ & 1 & $0-10$ & 1.14 & 3.21 & 0.36 & 0.46 \\
\hline SG & 2 & $0-10$ & 1.06 & 3.11 & 0.34 & 0.43 \\
\hline SG & 3 & $0-10$ & 1.20 & 3.17 & 0.38 & 0.41 \\
\hline $\mathrm{CC}$ & 1 & $10-20$ & 1.22 & 3.06 & 0.40 & 0.34 \\
\hline $\mathrm{NC}$ & 1 & $10-20$ & 1.16 & 2.57 & 0.45 & 0.30 \\
\hline $\mathrm{CC}$ & 2 & $10-20$ & 1.22 & 3.07 & 0.40 & 0.33 \\
\hline $\mathrm{NC}$ & 2 & $10-20$ & 1.25 & 2.57 & 0.49 & 0.31 \\
\hline $\mathrm{CC}$ & 3 & $10-20$ & 1.15 & 3.08 & 0.37 & 0.33 \\
\hline $\mathrm{NC}$ & 3 & $10-20$ & 1.21 & 2.57 & 0.47 & 0.29 \\
\hline GM & 1 & $10-20$ & 1.10 & 3.06 & 0.36 & 0.31 \\
\hline GM & 2 & $10-20$ & 1.16 & 3.08 & 0.38 & 0.34 \\
\hline GM & 3 & $10-20$ & 1.18 & 3.08 & 0.38 & 0.34 \\
\hline SG & 1 & $10-20$ & 1.23 & 3.16 & 0.39 & 0.34 \\
\hline SG & 2 & $10-20$ & 1.04 & 3.09 & 0.34 & 0.33 \\
\hline SG & 3 & $10-20$ & 1.22 & 3.12 & 0.39 & 0.34 \\
\hline $\mathrm{CC}$ & 1 & $20-30$ & 1.16 & 2.96 & 0.39 & 0.34 \\
\hline $\mathrm{NC}$ & 1 & $20-30$ & 1.13 & 2.58 & 0.44 & 0.35 \\
\hline $\mathrm{CC}$ & 2 & $20-30$ & 1.08 & 3.07 & 0.35 & 0.37 \\
\hline $\mathrm{NC}$ & 2 & $20-30$ & 1.23 & 2.58 & 0.48 & 0.33 \\
\hline $\mathrm{CC}$ & 3 & $20-30$ & 1.20 & 3.06 & 0.39 & 0.32 \\
\hline $\mathrm{NC}$ & 3 & $20-30$ & 1.14 & 2.57 & 0.44 & 0.29 \\
\hline GM & 1 & $20-30$ & 1.03 & 3.05 & 0.34 & 0.28 \\
\hline GM & 2 & $20-30$ & 1.07 & 2.98 & 0.36 & 0.35 \\
\hline GM & 3 & $20-30$ & 1.13 & 2.97 & 0.38 & 0.32 \\
\hline SG & 1 & $20-30$ & 1.18 & 3.09 & 0.38 & 0.32 \\
\hline SG & 2 & $20-30$ & 1.04 & 3.06 & 0.34 & 0.37 \\
\hline SG & 3 & $20-30$ & 1.14 & 3.16 & 0.36 & 0.32 \\
\hline
\end{tabular}


A 3.4. Thermal conductivity $(\lambda)$, volumetric heat capacity $\left(C_{V}\right)$, thermal diffusivity $(D)$, and volumetric water content $(\theta)$ at $-100 \mathrm{kPa}$ pressure measured in 2015 and used in chapter 5 . $\mathrm{CC}=$ cover crops, $\mathrm{NC}=$ no cover crop, $\mathrm{GM}=$ giant miscanthus, and $\mathrm{SG}=$ switchgrass.

\begin{tabular}{|c|c|c|c|c|c|c|}
\hline Treatment & Rep & $\begin{array}{c}\text { Depth } \\
\text { (cm) }\end{array}$ & $\begin{array}{c}\lambda \\
\left(\mathrm{W} \mathrm{m}^{-1} \mathrm{~K}^{-1}\right)\end{array}$ & $\begin{array}{c}C_{V} \\
\left(\mathbf{M J ~ m}^{-3} \mathbf{K}^{-1}\right)\end{array}$ & $\begin{array}{c}D \\
\left(\mathrm{~mm}^{2} \mathrm{~s}^{-1}\right)\end{array}$ & $\begin{array}{c}\theta \\
\left(\mathrm{cm}^{3} \mathrm{~cm}^{-3}\right)\end{array}$ \\
\hline $\mathrm{CC}$ & 1 & $0-10$ & 1.11 & 3.07 & 0.36 & 0.34 \\
\hline $\mathrm{NC}$ & 1 & $0-10$ & 1.16 & 2.50 & 0.46 & 0.28 \\
\hline $\mathrm{CC}$ & 2 & $0-10$ & 1.18 & 3.01 & 0.39 & 0.35 \\
\hline $\mathrm{NC}$ & 2 & $0-10$ & 1.16 & 2.59 & 0.45 & 0.31 \\
\hline $\mathrm{CC}$ & 3 & $0-10$ & 1.13 & 3.16 & 0.36 & 0.36 \\
\hline $\mathrm{NC}$ & 3 & $0-10$ & 1.17 & 2.60 & 0.45 & 0.31 \\
\hline GM & 1 & $0-10$ & 1.01 & 3.11 & 0.33 & 0.36 \\
\hline GM & 2 & $0-10$ & 1.05 & 3.10 & 0.34 & 0.41 \\
\hline GM & 3 & $0-10$ & 1.11 & 3.12 & 0.36 & 0.42 \\
\hline SG & 1 & $0-10$ & 1.11 & 3.21 & 0.35 & 0.44 \\
\hline SG & 2 & $0-10$ & 1.03 & 3.12 & 0.33 & 0.40 \\
\hline SG & 3 & $0-10$ & 1.18 & 3.17 & 0.37 & 0.39 \\
\hline $\mathrm{CC}$ & 1 & $10-20$ & 1.19 & 3.10 & 0.38 & 0.30 \\
\hline $\mathrm{NC}$ & 1 & $10-20$ & 1.17 & 2.59 & 0.45 & 0.30 \\
\hline $\mathrm{CC}$ & 2 & $10-20$ & 1.19 & 3.01 & 0.39 & 0.30 \\
\hline $\mathrm{NC}$ & 2 & $10-20$ & 1.17 & 2.59 & 0.45 & 0.30 \\
\hline $\mathrm{CC}$ & 3 & $10-20$ & 1.12 & 3.11 & 0.36 & 0.30 \\
\hline $\mathrm{NC}$ & 3 & $10-20$ & 1.19 & 2.57 & 0.46 & 0.29 \\
\hline GM & 1 & $10-20$ & 1.07 & 3.07 & 0.35 & 0.29 \\
\hline GM & 2 & $10-20$ & 1.13 & 3.11 & 0.36 & 0.32 \\
\hline GM & 3 & $10-20$ & 1.13 & 3.11 & 0.36 & 0.33 \\
\hline SG & 1 & $10-20$ & 1.20 & 3.12 & 0.39 & 0.33 \\
\hline SG & 2 & $10-20$ & 1.01 & 3.11 & 0.33 & 0.32 \\
\hline SG & 3 & $10-20$ & 1.20 & 3.10 & 0.39 & 0.32 \\
\hline $\mathrm{CC}$ & 1 & $20-30$ & 1.09 & 3.00 & 0.36 & 0.29 \\
\hline $\mathrm{NC}$ & 1 & $20-30$ & 1.14 & 2.59 & 0.44 & 0.35 \\
\hline $\mathrm{CC}$ & 2 & $20-30$ & 1.02 & 3.09 & 0.33 & 0.34 \\
\hline $\mathrm{NC}$ & 2 & $20-30$ & 1.12 & 2.59 & 0.43 & 0.32 \\
\hline $\mathrm{CC}$ & 3 & $20-30$ & 1.13 & 3.08 & 0.37 & 0.29 \\
\hline $\mathrm{NC}$ & 3 & $20-30$ & 1.14 & 2.53 & 0.45 & 0.29 \\
\hline GM & 1 & $20-30$ & 1.00 & 3.04 & 0.33 & 0.27 \\
\hline GM & 2 & $20-30$ & 1.03 & 3.01 & 0.34 & 0.33 \\
\hline GM & 3 & $20-30$ & 1.11 & 3.00 & 0.37 & 0.30 \\
\hline SG & 1 & $20-30$ & 1.09 & 3.11 & 0.35 & 0.31 \\
\hline $\mathrm{SG}$ & 2 & $20-30$ & 1.02 & 3.09 & 0.33 & 0.35 \\
\hline $\mathrm{SG}$ & 3 & $20-30$ & 1.11 & 3.13 & 0.35 & 0.32 \\
\hline
\end{tabular}


A 3.5. Thermal conductivity $(\lambda)$, volumetric heat capacity $\left(C_{V}\right)$, thermal diffusivity $(D)$, and volumetric water content $(\theta)$ at $-300 \mathrm{kPa}$ pressure measured in 2015 and used in chapter 5 . $\mathrm{CC}=$ cover crops, $\mathrm{NC}=$ no cover crop, $\mathrm{GM}=$ giant miscanthus, and $\mathrm{SG}=$ switchgrass.

\begin{tabular}{|c|c|c|c|c|c|c|}
\hline Treatment & Rep & $\begin{array}{c}\text { Depth } \\
(\mathrm{cm})\end{array}$ & $\begin{array}{c}\lambda \\
\left(\mathbf{W ~ m}^{-1} \mathbf{K}^{-1}\right)\end{array}$ & 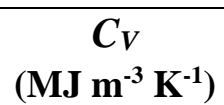 & $\begin{array}{c}D \\
\left(\mathrm{~mm}^{2} \mathrm{~s}^{-1}\right)\end{array}$ & $\begin{array}{c}\theta \\
\left(\mathrm{cm}^{3} \mathrm{~cm}^{-3}\right)\end{array}$ \\
\hline $\mathrm{CC}$ & 1 & $0-10$ & 1.11 & 3.03 & 0.36 & 0.32 \\
\hline $\mathrm{NC}$ & 1 & $0-10$ & 1.16 & 2.41 & 0.48 & 0.27 \\
\hline $\mathrm{CC}$ & 2 & $0-10$ & 1.16 & 3.00 & 0.39 & 0.34 \\
\hline $\mathrm{NC}$ & 2 & $0-10$ & 1.13 & 2.61 & 0.43 & 0.30 \\
\hline $\mathrm{CC}$ & 3 & $0-10$ & 1.12 & 3.12 & 0.36 & 0.34 \\
\hline $\mathrm{NC}$ & 3 & $0-10$ & 1.13 & 2.61 & 0.43 & 0.30 \\
\hline GM & 1 & $0-10$ & 1.00 & 3.09 & 0.32 & 0.38 \\
\hline GM & 2 & $0-10$ & 1.05 & 3.08 & 0.34 & 0.39 \\
\hline GM & 3 & $0-10$ & 1.10 & 3.10 & 0.35 & 0.38 \\
\hline $\mathrm{SG}$ & 1 & $0-10$ & 1.10 & 3.11 & 0.35 & 0.40 \\
\hline SG & 2 & $0-10$ & 1.02 & 3.12 & 0.33 & 0.36 \\
\hline SG & 3 & $0-10$ & 1.16 & 3.15 & 0.37 & 0.36 \\
\hline $\mathrm{CC}$ & 1 & $10-20$ & 1.17 & 3.03 & 0.38 & 0.28 \\
\hline $\mathrm{NC}$ & 1 & $10-20$ & 1.15 & 2.61 & 0.44 & 0.29 \\
\hline $\mathrm{CC}$ & 2 & $10-20$ & 1.18 & 2.96 & 0.40 & 0.28 \\
\hline $\mathrm{NC}$ & 2 & $10-20$ & 1.11 & 2.61 & 0.42 & 0.29 \\
\hline $\mathrm{CC}$ & 3 & $10-20$ & 1.11 & 3.09 & 0.36 & 0.28 \\
\hline $\mathrm{NC}$ & 3 & $10-20$ & 1.14 & 2.45 & 0.47 & 0.28 \\
\hline GM & 1 & $10-20$ & 1.06 & 3.07 & 0.35 & 0.27 \\
\hline GM & 2 & $10-20$ & 1.13 & 3.09 & 0.37 & 0.30 \\
\hline GM & 3 & $10-20$ & 1.13 & 3.10 & 0.36 & 0.30 \\
\hline SG & 1 & $10-20$ & 1.20 & 3.10 & 0.39 & 0.31 \\
\hline SG & 2 & $10-20$ & 1.01 & 3.10 & 0.33 & 0.29 \\
\hline SG & 3 & $10-20$ & 1.19 & 3.07 & 0.39 & 0.28 \\
\hline $\mathrm{CC}$ & 1 & $20-30$ & 1.08 & 3.00 & 0.36 & 0.28 \\
\hline $\mathrm{NC}$ & 1 & $20-30$ & 1.12 & 2.61 & 0.43 & 0.34 \\
\hline $\mathrm{CC}$ & 2 & $20-30$ & 1.01 & 3.07 & 0.33 & 0.32 \\
\hline $\mathrm{NC}$ & 2 & $20-30$ & 1.11 & 2.59 & 0.43 & 0.31 \\
\hline $\mathrm{CC}$ & 3 & $20-30$ & 1.12 & 3.07 & 0.36 & 0.28 \\
\hline $\mathrm{NC}$ & 3 & $20-30$ & 1.12 & 2.44 & 0.46 & 0.28 \\
\hline GM & 1 & $20-30$ & 1.00 & 3.02 & 0.33 & 0.29 \\
\hline GM & 2 & $20-30$ & 1.03 & 3.00 & 0.34 & 0.30 \\
\hline GM & 3 & $20-30$ & 1.11 & 3.00 & 0.37 & 0.28 \\
\hline SG & 1 & $20-30$ & 1.09 & 3.09 & 0.35 & 0.28 \\
\hline SG & 2 & $20-30$ & 1.01 & 3.08 & 0.33 & 0.33 \\
\hline SG & 3 & $20-30$ & 1.11 & 3.12 & 0.35 & 0.29 \\
\hline
\end{tabular}




\section{VITA}

Samuel Idoko Haruna was born at Ogodu (Nigeria) to Mr. Stephen Haruna and Mrs. Grace Haruna. He received his B.S. (Geology) in 2008 from Kogi State University, Anyigba (Nigeria) and M.S. (Environmental Sciences) in 2013 from Lincoln University, Missouri. He joined the University of Missouri in 2013 and received his PhD (Soil, Environmental and Atmospheric Sciences) in 2017 under the supervision of Dr. Stephen H. Anderson. He has accepted the position of Assistant Professor of Plant and Soil Science at Middle Tennessee State University, Murfreesboro. 